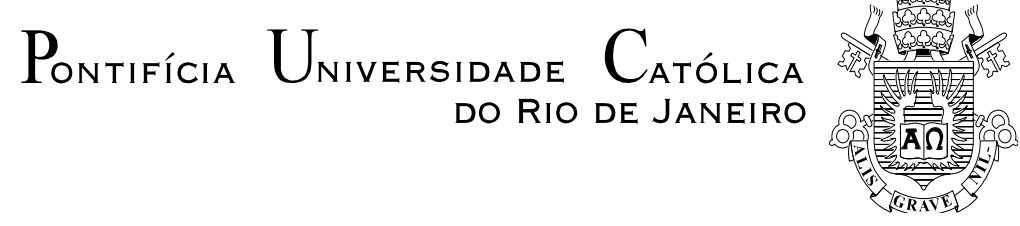

Pedro Federici Araujo

Democracia, Justificação e Comunicação: notas sobre um Brasil de desigualdades sociais

Dissertação de Mestrado

Dissertação apresentada como requisito parcial para obtenção do grau de Mestre pelo Programa de Pósgraduação em Direito do Departamento de Direito da PUC-Rio

Orientador: Prof. Florian Fabian Hoffmann Coorientadora: Prof ${ }^{a}$. Bethânia de Alburquerque Assy 


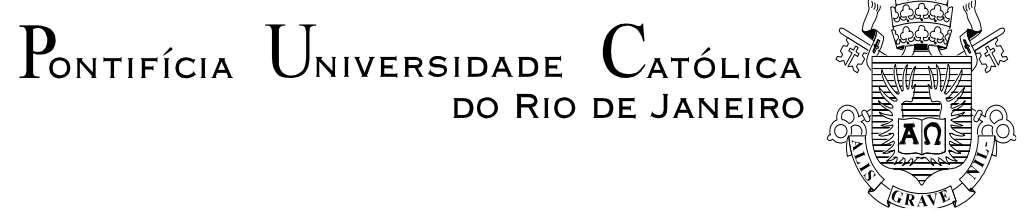

Pedro Federici Araujo

Democracia, Justificação e Comunicação: notas sobre um Brasil de desigualdades sociais

Dissertação apresentada como requisito parcial para obtenção do grau de Mestre pelo Programa de Pósgraduação em Direito do Departamento de Direito do Centro de Ciências Sociais da PUC-Rio. Aprovada pela Comissão Examinadora abaixo assinada.

Prof. Florian Fabian Hoffmann

Orientador

Departamento de Direito - PUC-Rio

Prof. Bethânia de Albuquerque Assy

Coorientadora

Departamento de Direito - PUC-Rio

Prof. Gisele Guimarães Cittadino

Departamento de Direito - PUC-Rio

Prof. Luiz Bernardo Leite Araújo

UERJ

Profa. Mônica Herz

Vice-Decana de Pós-Graduação do Centro de

Ciências Sociais - PUC-Rio

Rio de Janeiro, 10 de abril de 2017 
Todos os direitos reservados. É proibida a reprodução total ou parcial do trabalho sem autorização da universidade, do autor e do orientador.

\section{Pedro Federici Araujo}

Graduado em Direito pela Faculdade Nacional de Direito da Universidade Federal do Rio de Janeiro (2014). Candidato ao título de mestre em Direito pela Pontifícia Universidade Católica do Rio de Janeiro. Tem como principal área de interesse a teoria crítica do direito e se dedica principalmente às teorias democráticas e do Estado.

Ficha Catalográfica

Araujo, Pedro Federici

Democracia, Justificação e Comunicação: notas sobre um Brasil de desigualdades sociais / Pedro Federici Araujo ; orientador: Florian Fabian Hoffmann; coorientadora: Bethânia de Alburquerque Assy. - 2017.

182 f. ; $30 \mathrm{~cm}$

Dissertação (mestrado)-Pontifícia Universidade Católica do Rio de Janeiro, Departamento de Direito, 2017. Inclui bibliografia

1. Direito - Teses. 2. Democracia. 3. Justificação. 4. Ação Comunicativa. 5. Reconhecimento. 6. Representação. I. Hoffmann, Florian. II. Assy, Bethânia de Alburquerque. III. Pontifícia Universidade Católica do Rio de Janeiro. Departamento de Direito. IV. Título. 


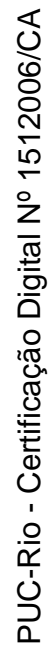

À Maria Lucia dos Santos, minha Mary. 


\section{Agradecimentos}

Agradeço a Deus porque até aqui ele me trouxe e me levará sempre adiante, agradeço pelo dom do amor que me deu de graça, um dom que não me impede, mas me obriga a amar, aceitar e respeitar o diferente. Algo tão difícil nos dias atuais.

"Falei tudo: sobre Tua fidelidade e Tua perfeição. Não retive parcelas de amor nem de verdade para meu consumo. Eu disse tudo que sabia; a congregação conheceu a história toda" Salmo. 40:40. (A Mensagem: Bíblia em Linguagem Contemporânea).

Agradeço ao meu querido avô Acyr Costa Araujo, exemplo de vida e de coração. Sempre incentivando, caminhando ao meu lado, durante minha trajetória acadêmica e profissional no meio jurídico, agora também filosófico e político, e sempre contribuindo criticamente para meus pensamentos e argumentos. Aos meus tios paternos, pelas companhias semanais, acompanhando as inseguranças e aflições de meu mestrado. Em especial, à minha tia Meise pela revisão de última hora e preocupação constante. Agradeço ao meu tio Henrique, pelas conversas e pelo acolhimento em sua casa durante o mestrado.

Aos meus pais, toda gratidão por me fazerem a pessoa que sou hoje, me apoiarem e permitirem que eu me dedicasse integralmente ao mestrado. Para Anna e Oliver, um agradecimento especial pelo acolhimento durante um período de visita acadêmica à Europa. À minha irmã Lia, o agradecimento pelo carinho e atenção de uma pessoa que compartilha tanto espaço da minha vida hoje. 
Agradeço imensamente à minha querida vizinha, amiga e professora Emi Vianna, por tornar o texto final deste trabalho legível, eliminando todos os vícios ruins de escritas adquiridos no ambiente jurídico. Aos meus amigos queridos, Los muchachos, não poderia faltar um agradecimento por fazerem parte da minha vida e por me aturarem do jeito que sou.

Um agradecimento ao meu orientador Florian Hoffmann, pelas provocações, críticas e ideias que fizeram dessa pesquisa muito melhor. Agradeço minha coorientadora Bethânia Assy, por ter adotado a mim e a minha pesquisa no último ano, sempre instigando a perspectiva crítica e incentivando as aventuras acadêmicas no exterior.

Ao $\mathrm{CNPq}$ e à PUC-Rio, pelos auxílios concedidos, sem os quais este trabalho não poderia ter sido realizado.

Por fim, aos meus colegas de mestrado, a turma Amor y Juego, que quebrou protocolos, costumes e se mostrou como o grupo mais amigo, solidário e capaz de compartilhar pensamentos críticos, mesmo atuando nos mais diversos campos acadêmicos. 


\section{Resumo}

Araujo, Pedro Federici; Hoffmann, Florian Fabian. Democracia Justificação e Comunicação: notas sobre um Brasil de desigualdades sociais. Rio de janeiro, 2017. 182p. Dissertação de Mestrado Departamento de Direito, Pontifícia Universidade Católica do Rio de Janeiro.

O contexto desta pesquisa é a crise do modelo democrático exclusivamente representativo. Ele é ambiência para a perpetuação de uma relação entre Estado e povo que não é baseada na comunicação e inviabiliza trocas de razões, típicas de relações de poder. O modelo representativo e um contexto de desigualdade social facilitam a dominação entre classes, negam reconhecimento aos pobres, prejudicando seu autorreconhecimento político, e impedem a comunicação entre governo e cidadão. Os conceitos de agir comunicativo, dominação e justificação, em Habermas e Forst, são fundamentais para um parâmetro democrático baseado na intersubjetividade. Democracia é um conceito em disputa. Não se pretende apresentar um conceito melhor, entretanto, analisam-se as conjunturas sociais e políticas que contribuem para um descrédito do modelo democrático e fortalecem estruturas de dominação e de agir estratégico incompatíveis com a democracia. Parte-se de um pressuposto onde a democracia deve atender a padrões de justiça e comunicação baseados em uma ética intersubjetiva. O modelo democrático não pode facilitar o agir estratégico, nem perpetuar estruturas de não reconhecimento e de dominação. A inserção de mecanismos de participação popular revela-se como amplificadora do caráter democrático, permitindo a diminuição da utilização do agir estratégico e uma abertura para o agir comunicativo e para a troca de relações de dominação por relações de poder. Esses mecanismos favorecem os locais de encontro e conflito, de interação entre os diferentes. Além de contribuírem para a amplificação do diálogo e a redução de estruturas estatais não representativas e não responsivas.

\section{Palavras-chave}

Democracia; Justificação; Ação Comunicativa; Reconhecimento; Representação; Participação Direta. 


\section{Abstract}

Araujo, Pedro Federici; Hoffmann, Florian Fabian (Advisor). Democracy, Justification and Comunication: notes about a Brazil of social inequalities. Rio de Janeiro, 2017. 182p. Dissertação de Mestrado Departamento de Direito, Pontifícia Universidade Católica do Rio de Janeiro.

The crisis of exclusive representative democracies is the scenario of this work. Representative democracies are environments for the perpetuation of relations that are not based on communication between State and people. They make the exchange of reasons typical from relations of power impossible. Contexts of representative democracies and social inequalities enable class domination, deny recognition to the poor and harm their political self-recognition, preventing communication between government and citizens. The concepts of communicative action, domination and justification in Habermas' and Forst's works are essential to build a democratic paradigm based on intersubjective relations. It is not intended to present a "rightful/truthful" concept of democracy. The aim is to analyze social and political contexts that discredit the democratic system and strengthen domination structures and strategic action that are incompatible with democracy. Starting at the point where democracies must comply with justice and communication standards based on intersubjective ethics. It cannot favor strategic action and sustain non-recognition and domination structures. In this sense, the adoption of direct participation mechanisms are able to amplify democratic feature of the system, enabling the reduction of strategic action cleaning the path for a communicative action. As well of allowing the shift from relations of domination to relations of power, granting intersubjective recognition. In addition, they foment spaces of encounter and conflict as interaction between strangers. It is possible that it concurs to the amplification of the dialogue and the reduction of non-representative structures that are not responsives.

\section{Keywords}

Democracy; Justification; Comunicative Action; Recognition; Representation; Direct Participation. 


\section{Sumário}

$\begin{array}{ll}\text { Introdução } & 12\end{array}$

1. O Brasil como Caso Paradigma para Análise Democrática 19

1.1. Representação, Coalizão, Governabilidade e Distanciamento do Povo

1.2. Sucessos e Insucessos da Participação Direta no Brasil 38

1.3. O Exemplo Brasileiro de Desigualdade e

(Não)Reconhecimento Intersubjetivo

2. Discurso, Justificação e Participação Direta

67

2.1. Participação Direta: Relação entre Agir Comunicativo e Agir

Estratégico

68

2.2. Participação Direta e o Direito de Justificação

86

3. Reconstruindo o Modelo Democrático: Comunicação, Reconhecimento e Justificação

3.1. A insuficiência do modelo representativo

113

3.2. Participação como Fiadora da Governabilidade

125

3.3. A institucionalização do Discurso através da Participação direta e o Modelo Democrático Reconstrutivista

4. Conclusão

5. Referências bibliográficas 


\section{Siglas}

CLS - Conselhos Locais de Saúde

IBGE - Instituto Brasileiro de Geografia e Estatística

PNAD - Pesquisa Nacional por Amostra de Domicílios

PNPS - Política Nacional de Participação Social

PSDB - Partido da Social Democracia Brasileira

PT - Partido dos Trabalhadores

SNPS - Sistema Nacional de Participação Social

SUS - Sistema Único de Saúde

\section{Tabelas}

Tabela 1 - Rendimento de pessoas em idade ativa.

Tabela 2 - Desigualdade - Coeficiente de GINI 2001-2012 
Emancipate yourselves from mental slavery None but ourselves can free our minds Have no fear for atomic energy 'Cause none of them can stop the time How long shall they kill our prophets While we stand aside and look? Some say it's just a part of it We've got to fulfill the Book BOB MARLEY, Reemption Song 


\section{Introdução}

Em uma democracia ocidental, nos dias de hoje, pode-se dizer que exercer o direito de voto é suficiente para que o cidadão se sinta representado por seus governantes? Pode o indivíduo, membro de uma comunidade política, dizer que se sente parte integrante do governo eleito diretamente para mandatos de Executivo e Legislativo? Ou ainda, o modelo democrático baseado exclusivamente na representação é suficiente para atender aos anseios de legitimação democrática dos cidadãos? A resposta negativa para todas essas perguntas informa o contexto no qual se insere a presente pesquisa: a crise política, e por que não filosófica, do modelo democrático baseado exclusivamente na representação. Esta crise se agrava em países onde há grande desigualdade social e os privilégios são guardados para poucos, dentre os quais estão os políticos. Em países desiguais, a cisão social evidencia, mais facilmente, a incompatibilidade do modelo representativo com os anseios democráticos atuais. Por essa razão, este trabalho usará o Brasil como parâmetro exemplificativo, país marcado pelo abismo social, com um modelo representativo que, historicamente, afasta o povo da política, permitindo a apropriação do poder por uma classe política sem afeição pelos parâmetros de democracia e justiça social.

Não seria somente clichê dizer que no Brasil muitos têm pouco e poucos têm muito. Em verdade, a frase coloquial não se aplica exclusivamente a terras tupiniquins, mas pode se verificar na conjuntura global. Nesse sentido, apesar das análises observarem ao momento e situação brasileira, mesmo com algumas peculiaridades sociais e culturais, os critérios e princípios teóricos que se pretende associar ao modelo democrático podem ser aplicados diante de outros cenários das democracias ocidentais. Ao retornar para a problemática social brasileira, vêse um modelo democrático que parece inviabilizar a representação de determinadas camadas sociais, ou ainda, de determinadas secções sociais ou raciais. A desigualdade social no Brasil se identifica com diversos grupos subrepresentados; o que permite inserir num contexto de diferença de classes outros fatores, como diferenças raciais, étnicas e culturais. Diversidade e pluralidade são marcas registradas do Brasil, admiradas pelo mundo em razão da beleza que a mistura e o diferente podem apresentar. Entretanto, não há apenas a face positiva 
dessa característica brasileira. Quando associada ao abismo social e às situações precárias como pobreza, fome e criminalidade, essa bela diversidade desaparece e, com raras exceções, as classes parecem não se misturar.

Esse é também o contexto do presente trabalho, uma situação social grave que repercute nos padrões democráticos brasileiros e tem consequência na compreensão e reconhecimento dos cidadãos pelo Estado e entre si. É bem verdade que a simbologia de cidades como o Rio de Janeiro, na mistura entre o morro, asfalto e praia, também deve evidenciar que, apesar da convivência, são dois - ou mais - mundos diferentes com diversos fatores e espaços sem comunicação ou reconhecimento entre si. Os limites e barreiras existem, as interseções também, mas não há como negar a existência de divergências éticas moldadas pela falta de compatibilidade de renda, pela diferença de costumes e culturas.

Ninguém fala de um não lugar. Porém, mesmo que a contextualização esteja contaminada pela própria teoria e viés ideológico inerente de qualquer autor reconhecer isso é medida de honestidade acadêmica -, rejeitar a existência dos efeitos negativos da desigualdade social, contaminada também por questões raciais, é retirar a realidade do cenário social brasileiro e até mesmo mundial. Um cenário que revela uma crise política de um modelo representativo insuficiente, contaminado pela desigualdade social e pelos diversos mundos incomunicáveis que ainda existem, nos dias de hoje.

Diante disso, há facilidades e dificuldades em justificar a importância e necessidade do presente trabalho. A facilidade se coloca ante a existência de uma conjuntura democrática em crise, onde não há identificação entre os papéis que o próprio modelo propõe, isto é - com o perdão da repetição -, o representante não procura representar o representado e, obviamente, o representado não se sente representado. Ora, o problema parece fácil de ser resolvido, afinal, bastaria que, na próxima eleição, o cidadão elegesse outro representante que não aquele, mas, algum outro que realmente representasse seus anseios e interesses. É justamente aí que se coloca a justificativa do presente trabalho, se essa solução simples não ocorre, parece haver alguma inconsistência no sistema democrático. Essa insuficiência do modelo democrático representativo será desenvolvida pela 
pesquisa dentro da complexidade da situação de não representação e dos possíveis caminhos que um modelo democrático deveria seguir para ser mais democrático.

No meio acadêmico, a complexidade da questão e a insuficiência do modelo representativo estão longe de ser temas novos, nesse aspecto, reside a dificuldade em justificar o presente trabalho. Afinal, em um mundo de veloz produção acadêmica, com nomes importantíssimos tratando sobre o tema democracia, o que dizer de novo? Provavelmente, não muita coisa. Desta reflexão, na justificativa da presente pesquisa, surge a sua possível originalidade: a reconstrução de um caminho democrático com base em princípios de justiça, relacionando-os diretamente ao contexto social e político de um país de grande desigualdade social. A clara identificação da realidade política com uma pesquisa crítica interdisciplinar pode contribuir ainda mais para o debate, incluindo também o Direito como ferramenta necessária para institucionalização de mecanismos capazes de reduzir os déficits democráticos do modelo representativo. Acredita-se que os mundos político, social e jurídico têm revelado a necessidade de abordagens filosóficas e práticas sobrepostas para a solução de problemas complexos tais como a legitimidade democrática. A teoria crítica procura articular essa interdependência e assim será feito no presente trabalho.

Diante de um contexto tão alargado, é importante definir precisamente o recorte do objeto que se pretende trabalhar. As questões específicas serão problematizadas em relação ao modelo democrático, oferecendo ideais de soluções capazes de orientar caminhos possíveis para o tratamento dos problemas apresentados. O objeto delimita-se na análise dos déficits democráticos do modelo baseado exclusivamente na representação, quanto aos aspectos de reconhecimento intersubjetivos dos cidadãos como sujeitos políticos, enquanto detentores de um direito à justificação das ações do ente político segregado. O que incluirá, principalmente, fatores de comunicação no que se refere à responsividade entre representante e representado e à utilização de mecanismos de participação direta como redutores da distância que separa o cidadão do mundo político. Apesar da forte marca de um objeto teórico, haverá constantemente referência à prática democrática atual, não havendo uma separação clara entre objeto teórico ou empírico. 
Podem-se destacar os seguintes objetivos: (i) analisar e identificar as inconsistências e insuficiências do modelo democrático representativo; (ii) estabelecer parâmetros e princípios que devem orientar o modelo democrático para a realização de ideais de autogoverno do povo, comunicação e reconhecimento intersubjetivo enquanto sujeito político; (iii) verificar os benefícios da institucionalização de mecanismos de participação direta no modelo democrático representativo para que haja uma orientação da relação entre representante e representado com base em um agir comunicativo, que possibilite o reconhecimento dos cidadãos enquanto sujeitos políticos com direito à justificação.

Os objetivos estabelecidos para a presente pesquisa têm relação com os marcos teóricos que serão utilizados para o estabelecimento de critérios e parâmetros de uma eticidade intersubjetiva baseada na comunicação e no reconhecimento. O trabalho de Habermas permeará todo desenvolvimento sobre as formulações referentes ao agir comunicativo, agir estratégico e mundo da vida. A oposição entre agir comunicativo e agir estratégico aparece na relação dialógica entre Estado e cidadão, representada também entre classe política e povo. $\mathrm{Na}$ relação baseada em uma ética intersubjetiva, o agir comunicativo é essencial para que haja entendimento entre os participantes da comunicação, abrindo, inclusive, a possibilidade para que o interlocutor emita pretensões de validade e aceitação em relação aos enunciados do locutor, facilitando a compreensão dialógica necessária ao modelo democrático. Enquanto, através do agir estratégico, o locutor desconsidera o interlocutor como sujeito capaz de emitir enunciados de validade e aceitação, orientando sua ação apenas para os fins que pretende atingir, desconsiderando, por princípio, a posição do outro, dificultando a interlocução necessária a um modelo democrático responsivo.

A obra de Rainer Forst também aparece como marco teórico da pesquisa desenvolvida. As relações entre poder e dominação, tolerância como permissão ou como respeito e o princípio da justificação, todos interligados, orientarão a análise da insuficiência do modelo representativo e a reconstrução de caminhos democráticos, através de mecanismos de participação direta. No contexto de grande desigualdade social, a dominação aparece como ferramenta que exclui os espaços de trocas de razão típicas das relações de poder, imobilizando, através de 
violência ou não, determinada classe ou sujeito, pode-se chamar de uma perspectiva foulcaultiana de poder em relação à ética intersubjetiva habermasiana. No caso da presente pesquisa, fala-se do espaço político de trocas de razão inerente à democracia. A lógica do poder está inteiramente ligada às noções de tolerância como respeito e ao princípio de justificação, em que o eu, mesmo reconhecendo no outro um sujeito com costumes e orientações éticas diferentes, confere-lhe a qualidade de sujeito político com direito à justificação, que se revela através da compreensão da normatividade - formal ou não - como justificável para si.

Apesar de estarem em Forst e Habermas os referenciais teóricos do presente trabalho, outros autores serão importantes para o desenvolvimento de algumas ideias e para análise de determinadas conjunturas. Entre eles, Robert Dahl e Leonardo Avritzer aparecem como interlocutores permanentes da teoria continental alemã com a teoria democrática norte-americana e com a sociologia brasileira, respectivamente. De mesma sorte, não seria possível falar em reconhecimento, ainda que com base nos parâmetros de Forst do sujeito com direito à justificação, sem mencionar as dimensões e perspectivas de reconhecimento de Axel Honneth que parece trabalhar a normatividade da teoria do reconhecimento em âmbito sociológico, que é fundamental para análise de uma conjuntura democrática de desigualdade social; enquanto Forst tem uma formulação de reconhecimento reflexiva no âmbito político, igualmente importante para os objetivos do presente trabalho.

Diante deste quadro, são três as hipóteses que conduzirão o presente trabalho: (i) a democracia exclusivamente representativa facilita a existência de cenários de dominação, onde determinados sujeitos não são reconhecidos, enquanto titulares de um direito à justificação; (ii) contextos de larga desigualdade social agravam as crises de legitimidade do modelo de representação, uma vez que comprometem o compartilhamento de mundos da vida, impedindo relações intersubjetivas de reconhecimento e perpetuando situação históricas de não reconhecimento; (iii) mecanismos de participação direta diminuem os déficits democráticos dos modelos representativos, aumentam a possibilidade do agir comunicativo na relação entre Estado e cidadão, repercutem na esfera de 
reconhecimento intersubjetivo e na aproximação entre mundos da vida diferentes nos contextos de desigualdade social, reduzindo a possibilidade de dominação.

O método utilizado contará com larga análise bibliográfica de autores da teoria crítica, principalmente nas áreas relacionadas ao Direito, Sociologia e Política, mas não se furtará a análises empíricas. As partes empíricas serão sempre exemplificativas e não terão qualquer preferência por fontes primárias ou secundárias. O objetivo será, exclusivamente, relacionar teoria e prática para fortalecer os argumentos apresentados. Os argumentos e os caminhos democráticos serão desenvolvidos de forma reconstrutivista. Isto é, seguindo a tradição dos próprios autores, marcos teóricos do presente trabalho, Habermas, Forst e até Honneth, os argumentos e desenvolvimentos formulam-se a partir da reconstrução de um paradigma democrático com base em mais de uma teoria, princípio ou formulação de justiça. Habermas é reconhecido por ser o mediador entre liberais e comunitários e sua obra parte da reconstrução do trabalho de diversos autores, entre eles, Kant, Hegel, Freud e Marx. Forst e Honneth não são diferentes, introduzindo também, além dos autores mencionados, perspectivas de Foucault, Mead, Sartre, entre outros. Essa opção não representa nenhum tipo de ausência de rigor metodológico, apenas requer mais esforço do autor para concatenar as ideias e compatibilizar autores, algumas vezes divergentes. É possível que a leitura ressalte aos olhos ideias kantianas ou hegelianas, mas vale lembrar que o recorte teórico e o próprio recorte do objeto não permitem a análise profunda desses autores, no sentido de que essas ideias serão sempre do Kant de Habermas ou do Hegel de Honneth, por exemplo. Ainda na mesma linha de explicação metodológica, o desenvolvimento reconstrutivista também seleciona o que importa em cada autor para a reconstrução do argumento que se pretende, portanto, não há qualquer compromisso deste trabalho com as ideias dos autores que não sejam trazidas para argumentação.

Como proposição de caminho a percorrer, inicia-se com uma leitura do quadro democrático brasileiro, as implicações do modelo representativo de presidencialismo de coalizão, as crises de legitimidade, a falta de identificação do povo e a existência de mecanismos de participação direta no cenário atual, suas consequências, conquistas e derrotas. Em seguida, a análise de um cenário social de desigualdade que prejudica o reconhecimento de todos os cidadãos como 
sujeitos políticos partícipes de um regime democrático. Após isso, os conceitos e análises do cenário democrático brasileiro serão utilizados como parâmetro para o estabelecimento de princípios e caminhos capazes de melhorar a experiência democrática. Buscando dizer como formulações de ação comunicativa, reconhecimento e justificação podem oferecer parâmetros de construção de um modelo mais democrático e menos excludente. Por fim, será feita a tentativa de utilizar esses princípios para reconstrução de um modelo democrático misto entre representação e participação direta. Em que só o povo pode ser o fiador da legitimidade democrática do governo e dos representantes. 


\section{1.}

\section{O Brasil como Caso Paradigma para Análise Democrática}

Como já escrito na introdução, o sistema democrático brasileiro servirá de parâmetro para toda a análise da presente pesquisa. Mas é interessante que o leitor possa perceber as nuances e os problemas dos aspectos presentes nas democracias em caráter geral. Isto porque, uma vez que o caminho democrático que se propõe considera também princípios teóricos universalistas, aplicáveis à maioria das democracias ocidentais, acredita-se que seja possível obter parâmetros para melhora da experiência democrática de forma geral.

A democracia é certamente um conceito em disputa, seriam possíveis milhares de definições de democracia ou classificações quanto a modelos democráticos. Não parece ser essa a preocupação da presente pesquisa, não haverá uma tentativa em definir um conceito estanque democrático. É necessário, porém, preocupar-se com a legitimidade democrática do modelo, bem como a aproximação com os ideais de autogoverno do povo. Por mais que haja divergência entre conceitos e modelos democráticos, entende-se que não é possível afastar-se dessas ideias fundamentais relacionadas ao entendimento de democracia.

A ideia de legitimação democrática é vista de diversas formas, dentre as quais destacam-se três: a primeira delas, do ponto de vista contratualista tradicional, em que ao soberano - príncipe ou Estado - são dadas certas funções primordiais, como em Hobbes $^{1}$, a responsabilidade de garantir a segurança dos súditos. Caso o soberano falhe em cumprir essas funções, perde sua legitimidade. Obviamente, nos dias de hoje, a função do soberano agrega muito mais questões que a garantia da segurança, a lista de direitos fundamentais e sociais seria longa, caso se fizesse presente. A segunda forma de encarar a legitimidade tem relação com o modo pelo qual o príncipe presta contas aos súditos, isto é, a ideia de responsividade é fundamental para a compreensão da legitimidade democrática, nesse sentido, o trabalho de Robert Dahl é bem esclarecedor ao escolher esse critério, juntamente com as noções de inclusão e oposição, para entender o que

\footnotetext{
${ }^{1}$ HOBBES, T., Leviatã ou Matéria, Forma e Poder de um Estado Eclesiástico e Civil, p. 105-106 ou HOBBES, T., Do Cidadão, p. 198-199.
} 
chama de poliarquia ${ }^{2}$. Por fim, a terceira visão da legitimação democrática tem relação com a escolha de critérios morais norteadores de uma sociedade justa; no caso, a ideia de justificação de Forst será o elemento fundamental para tal visão, sendo necessário que haja uma estrutura básica de justificação no modelo para qualificá-lo como democrático. Acompanhando também a ideia do que se denominou democracia pragmática, a noção de legitimidade democrática pode resumir-se em meios de mediação capazes de aproximar Estado e sociedade civil, soberano e povo $^{3}$. Na mesma esteira da análise pragmática, a que se propôs essa teoria, não haverá separação radical entre análise empírica e análise teórica, no presente trabalho ${ }^{4}$. Porém, um ponto em que há divergência com a teoria pragmática trata-se da necessidade de recorrer a modelos contrafáticos para pensar as instituições, ainda que baseados em observações empíricas.

É preciso que as formas de encarar a legitimidade democrática sejam tratadas em conjunto para trabalhar o tema da democracia. Portanto, ainda que haja disputa em torno do conceito de democracia, pode-se definir uma densidade mínima, estabelecendo que o modelo democrático é mecanismo de aproximação de Estado e sociedade civil na polis, devendo ser legitimado com base no entendimento de que (i) o príncipe exerce o poder por delegação do povo, mantendo apenas o seu exercício, não a titularidade, podendo ser removido caso não cumpra as funções básicas que lhe são dadas. (ii) O príncipe não pode apenas cumprir as funções que lhe são dadas, mas também deve prestar contas aos cidadãos, mantendo um canal de diálogo e responsividade com o demos. (iii) As noções de justiça, reconhecimento e igualdade social caminham juntas aos conceitos de legitimidade democrática, uma vez que interferem diretamente no exercício de poder pelos cidadãos, permitindo que haja manutenção da titularidade do poder básico de autogoverno. Sem isso, seria difícil falar em democracia.

Neste capítulo, a questão da legitimidade será relacionada com aspectos fundamentais do cenário brasileiro que envolvam processos de tomada de decisão numa perspectiva macro política. Serão observadas as relações e consequências desses modelos com o reconhecimento intersubjetivo, as experiências de alteração

\footnotetext{
${ }^{2}$ DAHL, R. A., Polyarchy: participation and oposition, p. 220-221.

3 POGREBISCHI, T., Democracia Pragmática: Pressupostos de uma Teoria Normativamente Orientada, p. 660.

${ }^{4}$ Ibidem, p. 658.
} 
de paradigma no modelo decisório brasileiro, no que diz respeito à inclusão de mecanismos de participação direta, e como os aspectos de desigualdade social interferem ou são objeto desses processos decisórios.

O primeiro item trata do sistema macro político brasileiro, isto é, como o modelo representativo e de presidencialismo de coalizão tem orientado o sistema político para uma ideia de governabilidade que não tem por base o demos. Dessa forma, há uma aproximação da polis com o governo e afastamento do demos, enquanto deveria ocorrer o contrário ${ }^{5}$. Em uma análise habermasiana, há uma colonização da polis pelo agir estratégico dos sistemas do mercado e financeiro, quando deveria haver uma colonização da polis pelo mundo da vida baseado no agir comunicativo ${ }^{6}$.

O segundo item talvez seja o momento do trabalho em que mais se analisarão as peculiaridades do cenário brasileiro. Trata-se da observação das tentativas de introduzir mecanismos de participação direta no modelo de representação. Há larga experiência no Brasil sobre o assunto, num caminho de sucessos e insucessos, em que há certa resistência das classes políticas dominantes em permitir que o povo participe de determinadas áreas e de processos decisórios do governo. Essa vivência será fundamental para discutir como esse perfil antidemocrático, ou melhor, anticomunicacional do Estado dificulta os processos de alteração do status quo político e social, gerando um imobilismo baseado na dominação de camadas sub-representadas.

O terceiro e último item deste capítulo trata diretamente da relação entre desigualdade social e reconhecimento. A ideia é tratar dos cenários de não reconhecimento entre sujeitos do mesmo Estado, nas diferentes dimensões do reconhecimento intersubjetivo. A problemática do reconhecimento e do autorreconhecimento do sujeito, enquanto sujeito político, é cara ao tema da legitimidade democrática. Por essa razão, deve-se atentar para os processos histórico-sociais que continuamente excluem e negam espaços a determinadas

\footnotetext{
${ }^{5}$ Seminário interno do Programa de Pós-Graduação em Direito da PUC-Rio. Com o título Da representação: história natural e filosofia, ministrado pelo Professor Dr. Renato Lessa, entre os dias 24 e 28 de outubro de 2016.

${ }^{6}$ HABERMAS, J., Pensamento Pós-Metafísico, p. 80-81. A noção de separação da polis do mundo político e financeiro não é, exatamente, formulada em Habermas, há uma apropriação das noções de colonização do mundo da vida para pensar o ambiente democrático da polis como local onde deveria predominar o agir comunicativo.
} 
camadas sociais com base, por exemplo, em diferenças de renda, étnicas, religiosas e raciais.

\section{1. Representação, Coalizão, Governabilidade e Distanciamento do Povo}

Sem qualquer intenção de estender-se sobre um traçado histórico dos modelos de democracia, desde a polis grega, ou estabelecer critérios de como a representação também aparece para capturar o espírito democrático de autogoverno do povo, não é possível avançar sem estabelecer os parâmetros pelos quais a representação política se apresenta, segundo alguns autores, como única alternativa viável em países gigantes em território e população. Até mesmo porque, "sem perspectiva histórico-temporal adequada é impossível avaliar o processo de institucionalização democrática, em um país recém saído de 22 anos de autoritarismo militar"7.

A ideia democrática nasce sem o intermédio do representante na legislatura do Estado. Ainda que critérios de participação excluíssem determinadas pessoas do processo legislativo grego, a Àgora era o espaço onde todos os cidadãos qualidade restrita naquela época - poderiam participar do processo deliberativo na produção de leis e decisões ${ }^{8}$. Nesse sentido, uma vez tomando o termo democracia em associação ao seu modelo originário, não se podem chamar de democráticos os modelos ocidentais dos dias de hoje. Seja por argumentos sobre a impossibilidade de reunir em assembleia todos os membros dos Estados contemporâneos, seja pelo exercício de um modelo dominador que restringe o espaço público deliberativo a determinadas camadas da sociedade, o fato é que não se está falando da legislação direta do povo, no cenário atual, há um preenchimento da polis moderna pelo operador da representação.

Nesse sentido é interessante a diferenciação entre democracia formal ${ }^{9} \mathrm{e}$ substancial de Celso Antônio. A primeira representa a ideia de cumprimento

\footnotetext{
7 ABRANCHES, S., A democracia brasileira vai bem, mas requer cuidados: proposições sobre democracia brasileira e o presidencialismo de coalizão, p. 2.

${ }^{8}$ DAHL, R., A democracia e seus críticos, p. 27.

${ }^{9}$ Importante não confundir o que se chama de democracia formal com a forma procedimental adotada por Habermas. Ao determinar que a autonomia pública e privada pressupõe uma a outra e
} 
meramente formal no sistema deliberativo, capaz de introduzir a noção de governo do povo, gerando uma falsa sensação de pertencimento no processo decisório, geralmente, por meio de participação indireta na escolha de representantes; em que pode haver a estruturação de mecanismos de dominação que comprometem a qualidade democrática do sistema. Entretanto, na democracia substancial retomam-se os ideais democráticos reais de governo do povo para o povo $^{10}$, em que se considera, realmente, a igualdade entre os indivíduos, vislumbrando-se certos fins como as condições econômicas e sociais dos participantes do processo democrático ${ }^{11}$. Aqui há uma necessidade de conferir ao sujeito um reconhecimento enquanto pertencente àquela comunidade política, capaz de ver como justificável as normas sobre as quais se submete ${ }^{12}$.

Celso Antônio ainda explica que, em um Estado apenas formalmente democrático, o complexo institucional não ultrapassa uma mera fachada distinta da realidade, mesmo com a adoção de instituições democráticas em suas Constituições - com presença de eleições, distinção entre os poderes, existência de princípios como o da legalidade -, anotando que a democracia exige um mínimo de cultura política ${ }^{13}$. É verdade que as instituições políticas, sempre que não estão circundadas de conquistas sociais e de lutas, ficam à mercê do cerceamento de uma consciência democrática dotada de pressão e a eventuais entusiasmos de uma opinião pública esquizofrênica. Tudo isso permite, inclusive nos países mais desenvolvidos, que os setores dominantes manejem suas conveniências econômicas e políticas ${ }^{14}$.

O operador da representação não é, necessariamente, um agente ruim de dominação. A ideia de representação aparece na história da humanidade de diversas formas e, em sua essência, não deve ser associada aos mecanismos de

incorporar a cooriginalidade entre direitos humanos e soberania popular, Habermas incorpora características do modelo substancial ao seu paradigma procedimental, o que o afasta de qualquer aproximação com modelos democráticos meramente formais. Maiores informações nos itens $2.2 \mathrm{e}$ 3.3 abaixo.

${ }^{10}$ MELLO, C. A. B., de. A democracia e suas dificuldades contemporâneas, p. 1.

${ }^{11}$ BOBBIO, N.; MATTEUCCI, N.; PASQUINO, G., Dicionário de Política. p. 327-329.

${ }^{12} \mathrm{Na}$ perspectiva de Honneth, um reconhecimento intersubjetivo capaz de proteger condições de liberdade, onde é necessário articular as realizações pessoais sem coerção. HONNETH, A., The Struggle for Recognition: The Moral Grammar of Social Conflicts, p. 174. Para Rainer Forst, tratase de uma estrutura básica de justificação. FORST, R., Justification and Critique: Towards a Critical Theory of Politics, pp. 114-115.

${ }^{13}$ MELLO, C. A. B., op. cit., p. 2.

${ }^{14}$ Ibidem, p. 3. 
dominação de que tratará o presente trabalho. A problemática da representação aparece no momento em que esse operador entra no mundo político a fim de funcionar como filtro da totalidade do demos para alocação de uma polis viável nos Estados modernos ${ }^{15}$.

Como problematização ${ }^{16}$ originária do operador da representação no mundo político, pode-se levantar dois discursos de membros do parlamento inglês, no século XVI, em que há pretensão de representação plena do diferente, a partir do seu lugar de fala e de crença na presentação da universalidade de sujeitos através dos representantes, no caso, parlamentares.

Nós devemos despir-nos de nossas convicções e vestir a daqueles pelos quais falamos: porque eles falam através de nós. Se a matéria em questão toca o pobre, tomem-me por um homem pobre. Aquele que fala, certas vezes precisa ser o advogado, outras horas um pintor, um mercador, outras vezes um artífice. ${ }^{17}$

Porque todo homem inglês deve estar lá presente, em pessoa ou por procurações e atos, de que proeminência, estado, dignidade ou qualidade seja ele, do Príncipe (seja Rei ou Rainha) à pessoa mais baixa da Inglaterra. E o consentimento do Parlamento é tido como o consentimento de todos os homens. ${ }^{18}$

A primeira fala parte do pressuposto de que o representante é capaz de assumir a própria corporeidade dos representados e está baseada numa crença de que um sujeito é capaz de transfigurar-se em todos os outros pelos quais deve falar. Há uma crença praticamente metafísica de que um sujeito é capaz de representar milhares outros de características diferentes de si. A segunda proposição é ainda mais intrigante, a noção de que um número ínfimo de representantes parlamentares, seja qual for o processo de escolha da representação, é capaz de presentar a universalidade de sujeitos de uma comunidade e a universalidade de seus consentimentos. Compreender que todas

\footnotetext{
${ }^{15}$ Renato Lessa, vide nota 5.

${ }^{16}$ Importante estabelecer que a noção de problema não atribui, necessariamente, a condição negativa ao operador da representação, trata-se apenas de situação de incerteza e instabilidade no operador, uma vez que este não é capaz de comprometer-se efetivamente com o objetivo a que se propõe.

${ }^{17}$ Tradução livre. No original, em inglês: "We must lay down the respects of our own persons, and put on others, and their affections for whom we speak; for they speak by us. If the matter which is spoken of toucheth the poor, then think me a poor man. He that speaks, sometimes he must be a Lawyer, sometimes a Painter, sometimes a Merchant, sometimes a mean Artificer." Discurso de William Hakewill no parlamento inglês em 1601. Retirado de DEAN, D., Law-making and Society in Late Elizabethan England. The parliament of England, 1584-1601, p. 31.

${ }^{18}$ Tradução livre. No original, em inglês: "For everie Englishman is entended to bee there present, either in person or by procuration and attornies, of what preheminence, state, dignitie, or qualitie soever he be, from the Prince (be he King or Queene) to the lowest person of Englande. And the consent of the Parliament is taken to be everie mans consent." SIMTH, Sir T., De Republica Anglorum: A discourse on the Commonwealth of England, p. xxxvi.
} 
individualidades e multiplicidades subjetivas de uma comunidade estão presentes em um processo decisório de poucos é, por princípio, contraintuitivo ${ }^{19}$.

Não fosse pouco a contraintuitividade apresentada pelas proposições acima, é fundamental estabelecer que essas noções de representação pressupõem a capacidade de transfiguração do sujeito, o que demandaria uma ausência de identidade subjetiva e uma presença de neutralidade ideológica impossíveis de se conceber $^{20}$. Não há sujeitos que partem de não lugares ideológicos ou comunitários, a pretensão de racionalidade pura e capaz de abandonar seus vícios, costumes e pressupostos éticos é ficcional, impossível de atingir na realidade ${ }^{21}$. Sobre esse mito de imparcialidade e neutralidade, normalmente se constrói a exclusão de determinados segmentos da população que perdem seus espaços de fala e de participação.

O modelo puramente representativo aparece no que se chama de teoria romano-medieval, em que se estabelece uma distinção entre titularidade e exercício de poder, em razão da soberania popular. Isso porque o povo não é um corpo perfeitamente homogêneo e, segundo essa visão, um sistema deve ser erigido para tornar possível a fluência do poder, através de representantes do povo que possam equilibrar os interesses dos indivíduos ${ }^{22}$. Molda-se uma noção de democracia no sentido de que quem governa age com a autoridade que the foi outorgada pelo povo, em razão da soberania popular ${ }^{23}$, tudo com base na ideia de representação. Robert Dahl assim explora o ponto: “A função apropriada do povo não é governar, como era em Atenas, e sim escolher líderes competentes para desempenhar a difícil função de governar toda a república"24.

Nesse momento, a democracia começa a ser moldada de forma a negar a possibilidade fática dos modelos predecessores nos quais a participação direta se

\footnotetext{
${ }^{19}$ Renato Lessa, vide nota 5.

${ }^{20}$ YOUNG, I., O ideal da Imparcialidade, p. 305; 321-323; 329. Na realidade a pretensão de imparcialidade e neutralidade apenas exclui determinados segmentos da comunidade.

${ }^{21} \mathrm{~A}$ ideia não é negar qualquer possibilidade de que um sujeito é capaz de representar o outro em seus interesses, apenas ressaltar a incoerência teórica e prática da afirmação de que a representação política é o mecanismo pelo qual todo o demos se faz representado no processo decisório governamental. $\mathrm{O}$ que não impede nenhuma argumentação de que é o melhor mecanismo para preservar a alocação da ideia de autogoverno no Estado moderno. Desde que jamais se esqueça de suas inconsistências.

${ }^{22}$ DAHL, R. A., A democracia e seus críticos, p. 37.

${ }^{23}$ BOBBIO, N.; MATTEUCCI, N.; PASQUINO, G., Dicionário de Política, p. 322.

${ }^{24}$ DAHL, R. A., op. cit., p. 38.
} 
daria pelo povo totalmente reunido para tomar decisões. Ao contrário, pensa-se em assembleias onde não há presença de todo o povo, mas apenas de seus representantes. A participação é "redefinida [...] como manifestação daquela liberdade particular que [...] compreende ainda o direito de eleger os representantes para o Parlamento e de ser eleito" 25 . Este ideal de democracia foi, principalmente, atribuído ao pensamento liberal democrático, que associa a democracia às liberdades individuais, mas que incutiu a ideia de representação na forma de participação do cidadão, através da escolha.

Soma-se a isso uma certa captura do operador da representação por parte de elites sociais e políticas a fim de afastar o povo da polis, ou seja, retirar o caráter presencial autolegislativo da democracia grega original. Essa aceitação e compatibilidade não se dá por uma percepção altruísta das elites, mas por uma compreensão de um modelo que pode ser considerado democrático, sem que essencialmente se altere o status quo. Isto é, ainda que se pense em democracia, os critérios estabelecidos para configurar a existência do sistema democrático dizem respeito, em regra, ao modelo de escolha e alienação do exercício do poder titularizado pelo povo, sem, necessariamente, estabelecer quais são os fins perseguidos. Portanto, permite-se que seja mantida uma lógica de dominação, e não de poder $^{26}$, favorecedora das elites ${ }^{27}$.

Em diversos momentos constitutivos históricos, esse processo pode ser facilmente identificado, mas cabe destacar a formação do Estado NorteAmericano e as cartas fundadoras de Madison, Jay e Hamilton. Na coletânea de artigos de $O$ Federalista, há uma aula de domesticação do povo e estruturação de um governo baseado no operador da representação. O operador da representação aparece como arma em favor de uma teoria "demofóbica". Prefere-se um modelo democrático tipicamente liberal, por esse motivo, as elites metropolitanas e as classes médias consideram a democracia participativa como suspeita,

\footnotetext{
${ }^{25}$ BOBBIO, N.; MATTEUCCI, N.; PASQUINO, G., op. cit., p. 324.

${ }^{26}$ A diferenciação entre poder e dominação é delineada por Forst, na ideia de que relações de poder pressupõe estruturas básicas de justificação, onde há aceitação pelo interlocutor das justificativas apresentadas para determinada ordem normativa ou situação social. Enquanto as relações de dominação revelam-se através da existência de uma ordem arbitrária carente de estruturas de justificação, onde não há aceitação por parte de um dos sujeitos. FORST, R., Justification and Critique: Towards a Critical Theory of Politics, p. 98; 113 passim.

${ }^{27}$ BOBBIO, N.; MATTEUCCI, N.; PASQUINO, G., op. cit., p. 325-326.
} 
antidesenvolvimentista e antinacional ${ }^{28}$. A recusa e a repulsa da animosidade e da instabilidade da multidão ou do povo em armas são a retórica utilizada para construção de instituições preenchidas por pessoas notáveis capazes de falar em nome de todos os cidadãos ${ }^{29}$. O Senado e a força desenhada em favor de um Poder Judiciário são estruturas necessárias para conter o ímpeto popular e guardar, para os mais "preparados", o poder de decisão sobre os demais.

É necessário deixar claro que a crítica direcionada ao processo de formação institucional norte-americano não se consubstancia exclusivamente nas instituições que se formam. Na verdade, há uma crítica aos fundamentos levantados para utilizar o operador da representação, enquanto filtro da capacidade e possibilidade de fala do demos. A supressão do conflito e do discurso que só pode ocorrer no encontro multifacetado dos diferentes é um golpe a um espírito democrático que deveria, ao inverso, influenciar as estruturações dos chamados Estados Democráticos de Direito.

Portanto, para tratar do tema de forma institucional, é preciso compreender a estrutura dos Estados modernos e identificar a ressonância dessa utilização equivocada do operador da representação, para permitir que as instituições existentes possam utilizar o mesmo operador em favor de um pensamento democrático. Para isso, é necessário ter em mente as noções de legitimidade democrática mencionadas anteriormente. Apresentadas as bases da insuficiência do modelo exclusivamente representativo, volta-se para a análise do cenário paradigma do Brasil, uma vez que este ponto merecerá melhor tratamento no capítulo 3.

Retornando para o cenário brasileiro, temos uma grande herança "demofóbica" herdada dos institucionalismos norte-americano e europeu, o que pode ser observado historicamente no Brasil. É possível dizer que a democracia brasileira sempre foi um bom pacto entre cavalheiros ou entre homens cordiais. A verdade é que o processo histórico brasileiro revela que as alterações institucionais, menores ou maiores, contaram poucas vezes com alta participação do povo. Grande parte dos historiadores afirma que é impossível dizer que o Brasil viveu um momento revolucionário popular em qualquer de suas transições.

${ }^{28}$ SANTOS, B. de S.; ARVRITZER, L., Introdução: para ampliar o cânone democrático, p. 67.

${ }^{29}$ HAMILTON; MADISON; JAY., O Federalista, p. 374 e 382. 
Da independência, passando pela proclamação da república, até a redemocratização em 1988, todas as transições foram detalhadamente transacionadas pelos detentores do poder do Estado e pelas elites que assumiriam o papel dominante na nova forma institucional. Sérgio Buarque de Holanda vem dizer que a "democracia no Brasil sempre foi um lamentável mal-entendido"30, enquanto Raymundo Faoro chama o país de "República Inacabada"31.

No raciocínio de Robert Dahl, para o qual a qualificação de um sistema em poliarquia se dá pelo aumento na inclusão do povo nos processos de decisão - o autor refere-se principalmente em relação ao voto direto $-{ }^{32}$, pode-se dizer que as diferentes camadas excluídas como mulheres, negros e analfabetos tiveram seus sufrágios permitidos apenas de maneira gradual na história brasileira. A evolução da participação apenas no momento eleitoral brasileiro foi lenta ${ }^{33}$, não havendo nenhum tipo de ruptura revolucionária que tenha efetivado essas alterações. Foi apenas em 1990, na posse de Fernando Collor, que o Brasil passava a ter todos os cargos Executivos e Legislativos do país escolhidos pelo voto popular, tendo sido um dos últimos países a estender o direito de voto para analfabetos ${ }^{34}$.

Todas as características interferem diretamente no modelo de representação que vigora nos dias de hoje. O cenário brasileiro é historicamente avesso à participação popular, as transições sempre ocorreram por meio do acordo "dos de cima" e o sufrágio direto para eleição de executivo e legislativo, que hoje é universal, não é capaz de gerar uma representação plural e responsiva. A representação no Brasil tem sido um mecanismo de implementação autocrática que nega o consentimento e desqualifica a participação no cenário político ${ }^{35}$.

Em termos numéricos, pode-se identificar e analisar o legislativo brasileiro e compará-lo à composição da população brasileira. Nas eleições de 2014, dos 513 deputados federais eleitos, apenas 51 eram mulheres, enquanto 462 eram homens,

${ }^{30}$ HOLANDA, S. B., Raízes do Brasil, p. 281.

${ }^{31}$ A nomenclatura é o próprio título de: FAORO, R. A., República Inacabada.

${ }^{32}$ DAHL, R. A., Polyarchy: participation and oposition, p. 23.

${ }^{33}$ O livro Eleições no Brasil de Jair Nicolau é um verdadeiro registro histórico para demonstrar como, a cada momento, os sujeitos foram sendo inseridos na arena política através do direito de voto. É possível afirmar que o processo de democratização brasileiro foi lento e gradual através dos detalhes da obra do autor ao informar os períodos e datas onde foram incluídos, por exemplo, negros, mulheres, analfabetos, jovens, entre outras categorizações utilizadas para limitar o sufrágio. Para maiores explicações ver obra completa: NICOLAU, J., Eleições no Brasil.

${ }^{34}$ Ibidem, p 123-124.

${ }^{35}$ FAORO, R. A., República Inacabada, p. 200. 
revelando percentuais aproximados de $10 \%$ e $90 \%$, respectivamente ${ }^{36}$. O último censo demográfico realizado em 2010, demonstrou que a população brasileira é composta de $51 \%$ de mulheres contra $49 \%$ de homens ${ }^{37}$. O sexo não é a única característica disfuncional na Câmara dos Deputados, veja-se a questão racial. Dos 513 deputados, 410 se declaram brancos, 81 se dizem pardos e 22 pretos, revelando um percentual de 79,9\% de brancos, enquanto pardos e pretos juntos somam 20,1\%. Enquanto isso, com base no Censo de 2010, pardos e pretos somam $50,7 \%$ e brancos $47,7 \%{ }^{38}$.

A discrepância e a disfuncionalidade dos números é gritante. Ainda que seja defensável o argumento de que a representação não precisa revelar exatamente as divisões de sexo, cor, raça ou religião, há uma proporcionalidade diametralmente inversa entre a realidade da população brasileira e a representação na Câmara dos Deputados Federal ${ }^{39}$. Dessa forma, os contorcionismos necessários para viabilizar o operador da representação revelam, mais facilmente, sua incapacidade de representar a população efetivamente. A transfiguração do representante ou sua necessária abstração para representar sujeitos tão díspares de si mesmo revela-se ineficiente e inconsistente, agravando o déficit democrático do modelo político.

É bem verdade que o Brasil é um país de diferenças, admirado pela convivência entre diferentes camadas sociais, raças e religiões, nas praias, no carnaval e na interseção entre morro e asfalto tão evidenciada em cidades como o Rio de Janeiro. Entretanto, há espaços que não são compartilhados e muros que, por mais que encobertos, impedem a comunicação entre sujeitos estranhos. A senzala nunca ganhou total espaço na casa grande brasileira. Ao analisar criticamente a ideia de democracia racial, Alfredo César de Melo faz distinção entre a "democracia racial como máscara" e "democracia racial como utopia". A distinção tem por base a obra de Gilberto Freyre para reconhecer que o mito da democracia racial no Brasil serviu para encobrir a realidade racista e intolerante das transições democráticas. No Brasil, a exaltação à convivência entre os

\footnotetext{
${ }^{36}$ TSE (Brasil)., Estatísticas eleitorais 2014.

${ }^{37}$ IBGE (Brasil)., Censo 2010: Brasil em síntese, distribuição da população por sexo.

${ }^{38}$ LOCATELLI, P., Brancos serão quase $80 \%$ na Câmara dos Deputados.

39 Como registrado na introdução, os dados empíricos serão todos exemplificativos para comprovar os argumentos desenvolvidos. Entretanto, não há nenhuma razão para desconfiar que a reprodução dessas inconsistência não ocorra nas outras instituições do país.
} 
diferentes mascara a realidade de segregação da população ${ }^{40}$. O negro pobre continua a não participar dos espaços reservados a uma elite social e política. Vide, por exemplo, a ausência de participação política na Câmara dos Deputados. Sobretudo, a persistência de problemas de discriminação racial, contra a mulher e a manutenção de uma pobreza estrutural trazem a conclusão de que as instituições democráticas brasileiras são incapazes de resolver tais problemas ${ }^{41}$.

Pode-se dizer que na estrutura social brasileira, ao negro pobre ${ }^{42}$ é negado reconhecimento intersubjetivo. Seja em uma concepção de reconhecimento, enquanto sujeito com direito à justificação, quanto em uma concepção de sujeito de necessidades básicas. A primeira concepção é do autor Rainer Forst e tem relação com a necessidade de conferir a todos os sujeitos a qualidade de sujeitos com direito à justificação das estruturas normativas existentes. A dignidade humana está diretamente relacionada com a capacidade e possibilidade dos sujeitos de entenderem como justificáveis todas as relações existentes nas comunidades onde estão inseridos ${ }^{43}$. Em outro olhar, a dimensão de reconhecimento enquanto sujeito com necessidades básicas é base da ética intersubjetiva estabelecida por Honneth, no sentido de que todos os sujeitos devem reconhecer no outro um sujeito com necessidades básicas, não só fisiológicas, mas também de afeto ${ }^{44}$. Essas categorias serão melhores desenvolvidas, quando da reconstrução dos paradigmas de justiça necessários ao conceito de legitimidade democrática. Entretanto, é fundamental que, durante toda leitura deste capítulo, tenha-se em mente que a palavra reconhecimento, sempre que utilizada, tem por base essas noções políticas e sociológicas de justiça.

Há uma verdadeira ressonância nessa ausência de reconhecimento e justificação na percepção social em relação ao sistema político e à representação. A expressão não me representa vai muito além da insatisfação com determinado político ou partido, trata-se de uma vontade popular em alterar a forma como a

\footnotetext{
${ }^{40}$ MELO, A. C., Saudosismo e crítica social em Casa grande \& senzala: a articulação de uma política de memória e de uma utopia, p. 287.

${ }^{41}$ ABRANCHES, S. A, democracia brasileira vai bem, mas requer cuidados: proposições sobre democracia brasileira e o presidencialismo de coalizão, p. 3.

${ }^{42}$ Ao falar do preto pobre, trata-se apenas de uma das camadas sub-representadas e a que é negada reconhecimento no Brasil. O exemplo é utilizado como paradigma mas não é exaustivo para evidenciar as diversas estruturas de não reconhecimento no país.

${ }^{43}$ FORST, R., The Right to Justification: elements of a constructivist theory of justice, p. 192.

${ }^{44}$ HONNETH, A., The Struggle for Recognition: The Moral Grammar of Social Conflicts, p. 95.
} 
representação é exercida ${ }^{45}$. Isto é, há um problema com o sistema representativo em si, em que os políticos entendem que, após o voto direto, a função do povo não é mais exercer sua soberania, mas há uma alienação dessa soberania aos representantes. Por uma lado, há um entendimento político-filosófico em relação ao modelo representativo ${ }^{46}$ e, por outro, uma descrença no povo como subjetividade capaz de opinião e reivindicação ${ }^{47}$. É um entendimento antiquado da representação como instrumento de mediação política entre Estado e sociedade civil, que deve sofrer mutação permanente adequando-se às novas lógicas de necessidade responsiva dos cargos eleitos ${ }^{48}$.

Vê-se então que o modelo baseado exclusivamente na representação permite a manutenção de uma classe política autocrática e/ou oligarca que rechaça os valores democráticos de autogoverno do povo. É impossível chamar de democracia um modelo em que não há qualquer retorno ao seu fundamento primordial, que é a noção de soberania popular do poder constituinte ${ }^{49}$. Nas palavras de Abranches, há um déficit sistêmico de relação entre representante e representado ${ }^{50}$.

Os problemas da representação política moderna associam-se a duas outras graves características do sistema político brasileiro que, nas palavras de Avritzer, contribuem para os impasses da democracia no Brasil: o presidencialismo de coalizão e a governabilidade. O presidencialismo de coalizão é uma ferramenta do sistema político em virtude de uma forma de eleição proporcional, em que o presidente é eleito com uma quantidade de votos muito superior a de seu partido ${ }^{51}$. Ele nasce com o intuito de solucionar anseios populares de respostas rápidas institucionais para os problemas da população. Introduz na arena política a possibilidade de associação entre executivo e maiorias parlamentares capazes de aprovar e permitir o andamento do governo. Nesse sentido, o presidencialismo de

${ }^{45}$ AVRITZER, L., Impasses da Democracia no Brasil, p. 27.

${ }^{46}$ DAHL, R. A., Polyarchy: participation and oposition, p. 122.

${ }^{47} \mathrm{O}$ próprio Faoro reconhece que há uma herança do tratado político do Federalista, em que o político tem medo do povo, o vê como agitador e baderneiro. FAORO, R., A República Inacabada, p. 228.

48 POGREBISCHI, T., A Democracia Pragmática: Pressupostos de uma Teoria Normativa Empiricamente Orientada, p. 661.

${ }^{49}$ FAORO, R. A., op. cit., p. 211.

${ }^{50}$ ABRANCHES, S. A., democracia brasileira vai bem, mas requer cuidados: proposições sobre democracia brasileira e o presidencialismo de coalizão, p. 10

${ }^{51}$ AVRITZER, L, op. cit., p. 30. 
coalizão tem a possibilidade de gerar o que se chama de governabilidade. Mas pode ser considerado como o maior dilema de nosso sistema democrático ${ }^{52}$.

Nas palavras de Paulo Sergio Peres, é um modelo que deve ser compreendido no âmbito da transição de regimes autoritários para regimes democráticos ${ }^{53}$. Em que havia a preocupação de que os regimes democráticos pudessem se consolidar. É evidente que as histórias brasileira e sul-americana têm se contraposto a essa ideia de consolidação, uma vez que é recorrente a quebra de governo em razão de má-performance econômica, conforme escreve Peter Kingstone $^{54}$. Sérgio Abranches vai apontar o seguinte:

O raciocínio acima aponta para o nó górdio do presidencialismo de coalizão. É um sistema caracterizado pela instabilidade, de alto risco e cuja sustentação baseia-se, quase exclusivamente, no desempenho corrente do governo e na sua disposição de respeitar estritamente os pontos ideológicos ou programáticos considerados inegociáveis, os quais nem sempre são explícita e coerentemente fixados na fase da formação da coalizão. ${ }^{55}$

Ou seja, ao contrário do que pensam muitos analistas do modelo institucional brasileiro em afirmar que o Presidente detém grande parte do poder de agenda legislativa ${ }^{56}$, categoricamente, isso não é possível de se afirmar. O poder de agenda legislativa não é concentrado independentemente nas mãos do chefe do Poder Executivo, na verdade, seu poder de agenda depende da manutenção de uma coalizão majoritária no Congresso Nacional. É bem verdade que as coalizões conferiram esse "superpoder" ao Presidente quase perfeitamente durante os governos de Fernando Henrique Cardozo, Lula e em boa parte do primeiro mandato do governo Dilma Rousseff. Os dois lados do presidencialismo de coalizão já foram experimentados na realidade brasileira, desde a Constituição de 1988. Seja pela ascensão do presidencialismo de coalizão entre 1994 e 2002 ou entre 2006 e 2012, como identifica Avritzer ${ }^{57}$, ou por suas crises entre 2003 e 2005, e entre 2015 e 2016, evidenciando o cenário caótico que culminou no impedimento da Presidente Dilma Rousseff.

52 ABRANCHES, S., A democracia brasileira vai bem, mas requer cuidados: proposições sobre democracia brasileira e o presidencialismo de coalizão, p. 11

53 PERES, P. S. A., A barganha nas vísceras do modo brasileiro de governar.

54 KINGSTONE, P. R., Muddling Through Gridlock: Economic Performance, Business Responses, and Democratic Sustainability, p. 185-187.

${ }^{55}$ ABRANCHES, S., O presidencialismo de coalizão: o dilema institucional brasileiro, p. 27.

56 LIMONGI, F., A Democracia no Brasil: Presidencialismo, coalizão partidária e processo decisório, p. 20.

${ }^{57}$ AVRITZER, L., Impasses da Democracia no Brasil, p. 31. 
O segundo mandato da Presidente Dilma é evidência clara de que o Executivo tem seu poder de agenda congelado diante da indisciplina da base de apoio, isto é, da infidelidade ou ausência de coalizão. Quando o Presidente deixa de exercer atração sobre a formação majoritária da Câmara, esta procura outro líder para que possa constituir a maioria ${ }^{58}$. Entre 2015 e 2016, houve a formação de uma coalizão em torno do então Presidente da Câmara dos Deputados Eduardo Cunha, formada pela indisciplinada base governista e pela oposição. O poder de agenda e de não-agenda ficou concentrado nas mãos de uma maioria legislativa e não no Executivo ${ }^{59}$. Fica claro que a dependência de uma coalizão pode impedir totalmente o Executivo de promover a agenda para o qual foi eleito, gerando uma ingovernabilidade ${ }^{60}$ e uma crise institucional.

Seja qual for o momento experimentando pelo presidencialismo de coalizão, gerando governabilidade ou não, há uma relação direta entre esse mecanismo e os custos que se impõem ao chamado sistema democrático. Avritzer elenca três custos ou limites: “(a) os custos crescentes da fragmentação partidária; (b) a desorganização administrativa gerada pela distribuição de cargos no governo; (c) e a propensão à corrupção gerada pela distribuição desses cargos."61

Os segundo (b) e terceiro (c) limites são mais importantes para a abordagem que se propõe, já que a fragmentação partidária, apesar de mostrar-se como grande fator de instabilidade, não é problemática em sua essência. No que se refere à desorganização administrativa, há um problema que se estabelece claramente entre agenda política aprovada nas urnas na eleição presidencial e sua inexecução, a partir das alianças necessárias para a construção da governabilidade. É evidente que a agenda do Executivo não é suficiente para a formação de alianças capazes de aprovar suas proposições ${ }^{62}$.

A coalizão exclusivamente partidária jamais será suficiente para conferir um poder de agenda ao Executivo, porque são necessários diversos partidos com

\footnotetext{
58 ABRANCHES, S., A democracia brasileira vai bem, mas requer cuidados: proposições sobre democracia brasileira e o presidencialismo de coalizão, p. 15.

${ }^{59}$ PERES, P. S. A., A barganha nas vísceras do modo brasileiro de governar.

${ }^{60}$ AVRITZER, L., Impasses da Democracia no Brasil, p. 29.

${ }^{61}$ Ibidem, p. 11.

${ }^{62}$ Ibidem, p. 32.
} 
ideologias e agendas políticas diferentes ${ }^{63}$. Há, portanto, um descompasso gigantesco entre agenda necessária para formar a coalizão e agenda aprovada nas urnas por voto direto universal.

Os partidos ditos de esquerda vivem paradoxo e controvérsia ainda maiores nesse momento, porque precisam buscar coalizões de centro ou centro-direita que bloqueiam completamente a possibilidade de uma agenda mais radical de alteração do status quo. Fica-se entre o dilema de não fazer alianças e nada aprovar, ou de fazer alianças e ter grande parte da agenda progressista bloqueada em função da coalizão formada ${ }^{64}$.

Há, por parte de todos os governos, o conhecimento do jogo político e das posições existentes no Congresso Nacional. Isto é, o Presidente sabe perfeitamente quais são as matérias que aprovará com sua coalizão e quais matérias poderão gerar um conflito capaz até de quebrar a base do governo. Por isso, ainda que existam ideias que contam com grande apoio da opinião pública, caso sejam capazes de destruir a base da coalizão, jamais serão propostas ${ }^{65}$. Talvez seja esta uma das situações mais injustificável aos olhos do povo, afastando a opinião pública do processo decisório.

No que toca a questão de corrupção, trata-se de um custo existente desde 1994 que, juntamente com os outros custos, cresce até os dias de hoje ${ }^{66}$. A descentralização do governo e o loteamento do mesmo, com base em áreas de interesse de um sistema partidário fragmentado, abrem espaço para escândalos de corrupção que desestabilizam o governo e corrompem a crença do cidadão no sistema político ${ }^{67}$. É possível dizer que esses custos cresceram até 2016, uma vez que os custos do presidencialismo de coalizão foram menores durante o governo Fernando Henrique Cardoso, pelos seguintes motivos:

a convergência entre base do governo e a sua agenda no Congresso era maior e os problemas decorrentes da coalizão, principalmente a má gestão e a corrupção, eram

\footnotetext{
${ }^{63}$ PERES, P. S. A., A barganha nas vísceras do modo brasileiro de governar.

${ }^{64}$ Idem.

${ }^{65}$ LIMONGI, F., A Democracia no Brasil: Presidencialismo, coalizão partidária e processo decisório, p. 29.

${ }^{66}$ Menciona-se o ano de 1994 porque é o ano em que se considera o início da ascensão do presidencialismo de coalizão, o que não havia ocorrido anteriormente. A escolha da data não significa que não existia corrupção antes de 1994.

${ }^{67}$ AVRITZER, L., Impasses da Democracia no Brasil, p. 35-36.
} 
mais facilmente assimiláveis pela base do governo e foram amplamente ignorados pelo Ministério Público e por grande parte da imprensa. [...] $]^{68}$.

Nos governos Lula e Dilma, existia verdadeira incompatibilidade entre a agenda do executivo eleito, sua base ideológica e as alianças necessárias para formar a governabilidade ${ }^{69}$. O que gerou crises do presidencialismo de coalizão e o aumento dos seus custos para a construção de uma governabilidade capaz de facilitar o andamento do governo. Nos últimos anos, é crescente a visão da opinião pública de que o presidencialismo de coalizão tem como pressuposto necessário a instauração da corrupção no meio político ${ }^{70}$. As formações das coalizões no governo Dilma, ao contrário do governo Lula, representaram verdadeiras derrotas no Congresso, principalmente, em razão da demissão de Ministros envolvidos em corrupção com grande força no parlamento ${ }^{71}$. A partir desse momento de crise do presidencialismo de coalizão, há a formação - ou amplificação - de estruturas de lobbies no Congresso Nacional para a manutenção do status quo, gerando uma necessidade de enfrentamento que se mostrou impossível para a manutenção do governo ${ }^{72}$.

O presidencialismo de coalizão firma-se como mecanismo de deslegitimação do sistema político, uma vez que o caráter ilegítimo - isto é, sem responsividade social, como as alianças e acordos construídos no Congresso supera a positividade dos elementos de capacidade de decisão do governo. Essa ilegitimidade representa-se na separação entre representante e representado, indicando a carência de autoridade e de legitimidade que acaba por revelar-se na utilização da força dominadora escancarada ou implícita do Estado $^{73}$. O desenho institucional perde qualquer adesão do povo em relação a sua constituição, tornando-se ilegítimo, uma vez que a adesão à forma institucional a que se submete é fator crucial para que o cidadão entenda uma estrutura normativa como legítima ${ }^{74}$.

\footnotetext{
${ }^{68}$ AVRITZER, L., Impasses da Democracia no Brasil, p. 36.

${ }^{69}$ Ibidem, p. 39.

${ }^{70}$ Ibidem, p. 43

${ }^{71}$ Ibidem, p. 44.

${ }^{72}$ Ibidem, p. 45.

${ }^{73}$ FAORO, R., A Republica Inacabada, p. 191.

74 ABRANCHES, S., A democracia brasileira vai bem, mas requer cuidados: proposições sobre democracia brasileira e o presidencialismo de coalizão, p. 3.
} 
Um discurso meramente estratégico de conveniências pessoais e particulares de partidos é incompreendido pelo povo, nesse sentido:

\begin{abstract}
Agora, as bases de sustentação do presidencialismo de coalizão, que são as barganhas envolvendo a troca de votos no parlamento por cargos e outros recursos, são vistas com grande desconfiança pela população em geral. O problema é que esse tipo de negociação política é o motor da dinâmica dos governos e partidos há muito tempo e em praticamente todos os países democráticos, com graus variados, obviamente. Não é mero acaso que ao mesmo tempo em que a democracia se tornou o único regime político considerado aceitável em todo o mundo, paradoxalmente, é crescente o descontentamento popular em relação às instituições representativas. (grifos aditados) ${ }^{75}$
\end{abstract}

Com isso, acaba gerando uma alienação de setores caros à manutenção da sustentação popular do Estado Democrático e do sistema político, como a classe média. As manifestações contrárias ao governo começam a aparecer, motivadas e catalisadas por uma imprensa que aponta cada vez mais os lados negativos de um sistema político instável e com graves problemas de corrupção ${ }^{76}$. O sistema político de representação, coalizão e governabilidade acaba por tornar-se injustificável aos olhos do cidadão, sujeito político primordial do sistema democrático, havendo conversão de estruturas de justificação e autoridades legitimadas para estruturas de dominação ${ }^{77}$ pela extorsão de uma maioria ${ }^{78} \mathrm{com}$ base em um agir estratégico ${ }^{79}$.

Em resumo, é possível dizer que os três pilares do institucionalismo brasileiro têm funcionado em movimento contrário a sua democracia. O operador da representação não tem sido capaz de gerar representatividade da população brasileira. Ainda que o regime de clientelismo e fisiologismo não seja inerente ao desenho institucional brasileiro, ele se reproduz nas estruturas de dominação que o mantêm na relação entre partidos, representantes e eleitores. Nas palavras de Abranches, um problema sociológico:

Não creio que o fisiologismo e o clientelismo sejam intrínsecos ao regime de governança. Eles são componentes do padrão de relacionamento entre partidos e eleitores, portanto um dado sociológico. Se os partidos majoritários logram conquistar essa maioria por meio desse tipo de mecanismos de manipulação do eleitor despossuído e não há alternativas competitivas em muitos redutos, a relação entre maioria legislativa e o Executivo terá, de fato, um elevado grau de propensão

\footnotetext{
${ }^{75}$ PERES, P. S. A., A barganha nas vísceras do modo brasileiro de governar.

${ }^{76}$ AVRITZER, L., Impasses da Democracia Brasileira, p. 47-48.

${ }^{77}$ FORST, R., Justification and Critique: Towards a Critical Theory of Politics, p. 103.

${ }^{78}$ FAORO, R., A Republica Inacabada, p. 202.

${ }^{79}$ HABERMAS, J., Pensamento Pós-Metafísico, p. 84.
} 
ao fisiologismo e ao clientelismo. Mas seria assim, se o governo não fosse de coalizão. $^{80}$

O presidencialismo de coalizão, ainda que possa ser olhado com bons olhos e gerar governabilidade em diversos momentos da história recente brasileira, não se tornou capaz de justificar-se aos olhos do povo. A incapacidade de conciliar agendas eleitas na figura da campanha presidencial com a necessidade da construção de alianças partidárias, fundamentais à estabilidade do governo, não é assimilada pelo cidadão enquanto sujeito político. Nessa lógica, há preferência de uma governabilidade que não tem por base o povo, o soberano maior de um Estado Democrático de Direito.

Não bastasse isso, os constantes escândalos de corrupção associam-se, a todo momento, ao modelo institucional de governança, o que o torna injustificável do ponto de vista moral normativo. Ainda que seja possível afirmar que estamos diante de um problema sociológico e não institucional, como poderia dizer Limongi, em análise crítica, a subsistência de um modelo institucional incompatível com a realidade social não se sustenta. Há uma crise de legitimidade institucional que é consequência natural de uma inabilidade do governo de resolver a crise política - e/ou sociológica - e a crise econômica ${ }^{81}$.

Existe verdadeira crise do sistema político que só pode ser resolvida por meio da expressão do poder constituinte, para que seja possível chamar o sistema de democrático ${ }^{82}$. É necessário que o desenho institucional funcione em consonância com os anseios populares. Para isso, os procedimentos decisórios devem ser capazes de apresentar estruturas básicas de justificação para todos os cidadãos. A agenda e não-agenda do Executivo e do Legislativo devem ter por base a vontade popular e não um fisiologismo e clientelismo partidários do acordo “dos de cima". A aproximação entre Estado e cidadão é inerente para a solução da crise de legitimidade das democracias atuais ${ }^{83}$.

Porém, não é esse o histórico brasileiro, ao inverso, a tradição diz que os detentores do poder irão solucionar a questão em um grande acordo nacional

80 ABRANCHES, S., A democracia brasileira vai bem, mas requer cuidados: proposições sobre democracia brasileira e o presidencialismo de coalizão, p. 14.

${ }^{81}$ HABERMAS, J., Legitimation Crisis, p. 69.

${ }^{82}$ FAORO, R., A Republica Inacabada, p. 181.

83 ABRANCHES, S., A democracia brasileira vai bem, mas requer cuidados: proposições sobre democracia brasileira e o presidencialismo de coalizão. p. 7 
capaz de estabilizar as instituições mas também manter o povo distante do Estado $^{84}$. Há sempre o impedimento da expansão do núcleo constitucional resolvido nos movimentos autocráticos de governo, há supressão de liberdades e direitos para a manutenção do status quo decisório ${ }^{85}$.

Por essa razão, torna-se necessário pensar no modelo democrático com base em critérios de legitimidade e justiça que possam apresentar mecanismos de decisão compatíveis com a participação do povo. Ainda que se fale em representação, presidencialismo de coalizão e governabilidade, esse desenho deve sofrer a interferência da participação popular direta, gerando estruturas de justificação que possam ser chamadas de democráticas. Identificar os problemas, as apropriações e a existência de estruturas de dominação - o que também será feito nos próximos dois itens - como tentou-se fazer nesse tópico, torna mais fácil pensar em soluções e estratégias de reformulação dos sistemas existentes.

\section{2. \\ Sucessos e Insucessos da Participação Direta no Brasil}

É importante recordar que este item objetiva, exclusivamente, observar as experiências de sucesso e insucesso da participação direta no Brasil, desde a redemocratização, com ênfase nos momentos de maior institucionalização dos mecanismos de participação popular e momentos paradigmáticos de posicionamento institucional e do povo. Uma vez que trabalha-se com a hipótese de que os espaços de participação direta são formas de aproximar os cidadãos da polis, estabelecendo estruturas de justificação e aumentando o reconhecimento intersubjetivo, é importante compreender se há indícios de que a hipótese pode ser verificada na prática ou não. Mais do que isso, entendendo que a amplificação do diálogo, através da participação direta, resulta em aumento de qualidade democrática do sistema ${ }^{86}$, ainda que se fale em um país com elevado grau de institucionalização de mecanismos de participação direta, por que razões isso não pode ser observado? Aproximando-se da metodologia proposta pelos estudos da

\footnotetext{
${ }^{84}$ HOLANDA, S. B., Raízes do Brasil, p. 281.

${ }^{85}$ FAORO, R., A Republica Inacabada, p. 185.

${ }^{86}$ POGREBISCHI, T., The Pragmatic Turn of Democracy in Latin America, p. 13.
} 
democracia pragmática, seria impossível discutir uma teoria política e democrática reconstrutivista sem observar as experiências de alteração e inovação nos sistemas existentes no Brasil.

O Brasil é visto, mundo a fora, como o verdadeiro exemplo de inovação democrática no que diz respeito à institucionalização de mecanismos de participação direta nos procedimentos públicos decisórios. A fama tem total razão no que toca a evolução institucional e legal em relação aos instrumentos de participação, entretanto, deve ser vista com certa desconfiança, já que é possível dizer que a participação social não foi capaz de produzir mudanças em todas as áreas da esfera pública, mais ainda, foi incapaz de adentrar áreas estruturais e problemáticas como infraestrutura e combate à corrupção ${ }^{87}$.

Este item vai tratar desse caminho de sucessos e insucessos da participação popular brasileira, seja ela institucionalizada ou não ${ }^{88}$. Considera-se que todos os espaços de preenchimento dos movimentos populares são espaços de trocas de razão e relações de poder, onde há discurso, comunicação, influência e manipulação ${ }^{89}$. Porém, é importante observar que as formas de participação popular nas estruturas do governo, por um lado, têm sido capazes de gerar estruturas de justificação, ampliando o espectro de reconhecimento aos cidadãos enquanto sujeitos com direito à justificação e aumentando o grau de reconhecimento intersubjetivo dos cidadãos enquanto sujeitos políticos ${ }^{90-91}$. Por outro lado, as limitações e barreiras ainda são gigantescas, não conseguiram ultrapassar as estruturas de dominação que se formam no seio dos sistemas eleitorais e da representação política propriamente dita, mas devem ser vistas como caminho no qual deve haver persistência e teimosia para sua ampliação.

No Brasil, o marco da institucionalização da participação é a Constituição de 1988, já em sua elaboração, as Emendas Populares tiveram grande papel de proposição e pressão sobre os constituintes, inserindo temas e previsões de grande

87 AVRITZER, L., Impasses da Democracia no Brasil, p. 16.

88 Apesar de se recorrer a outras fontes de informação, é necessário estabelecer que o caminho traçado vem da obra de Avritzer, em capítulo que trata exatamente da mesma temática.

${ }^{89}$ Segundo Forst, não há motivo para desconsiderar os espaços de manifestação corporal ou de análise de manifestação de espécie de biopoder foucaultiano como espaços de troca de razão. ALLEN, A.; FORST, R.; HAUGAARD, M., Power and Reason, Justice and Domination: a conversation, p. 19.

${ }^{90}$ AVRITZER, L., op. cit., p. 24.

${ }^{91}$ POGREBINSCHI, T., The Pragmatic Turn of Democracy in Latin America, p. 17. 
preocupação social no texto da Constituição. A Carta Magna traz, em seu corpo, a ideia de descentralização e fortalecimento dos poderes locais em diversas áreas, a mais louvada e elogiada, na seara da participação popular, é a saúde ${ }^{92}$. Entre outras coisas, a Constituição de 1988 também prevê mecanismos de participação direta como o plebiscito, o referendo, as audiências públicas, a possibilidade de iniciativa popular legislativa e muito mais ${ }^{93}$. Porém, é sabido que alguns desses instrumentos possuem estrutura demasiada trabalhosa e burocrática, de forma que são relegados a escanteio e acabaram ocorrendo em poucos momentos na história.

Em outra perspectiva, algumas formas institucionalizadas de participação popular podem ser utilizadas apenas de maneira formal, isto é, para legitimar um procedimento que seja capaz de invocar a sua veia democrática, sem efetivamente ter gerado participação de diversos setores da sociedade civil ${ }^{94}$. Nesse sentido, em alguns momentos, é possível verificar que a participação acontece apenas por movimentos organizados já ligados à administração pública, o que pode não ser essencialmente ruim, mas tende a representar uma legitimação formal do procedimento decisório sem que haja verdadeira interação entre governo e sociedade civil ${ }^{95}$. Não há qualquer tentativa de desqualificar os movimentos organizados que fazem parte das estruturas de governo, porém, uma das funções da participação direta é introduzir posições contrárias às identificadas com a representação tradicional eleita pelo sufrágio universal. Se não há incorporação de movimentos que não compõem o governo, não há também perspectiva diversa da já planejada e definida pelos agentes estatais.

Há grande possibilidade para a participação de movimentos sociais, sindicatos e associações através de ações judiciais de inconstitucionalidade, de inconstitucionalidade por omissão ou de descumprimento de preceito fundamental. O alargamento no rol de agentes possíveis de proporem ações constitucionais é também um reconhecimento de poder e ação aos movimentos sociais organizados. Algumas conquistas de direitos ocorreram por meio desse canal de participação, apesar de haver sempre uma tensão em qualificar como meio democrático o Poder Judiciário. A magistratura carece de qualquer tipo de

\footnotetext{
${ }^{92}$ COELHO, V. S. P., Conselhos de Saúde no Brasil: incluindo os excluídos?, p. 61.

${ }^{93}$ Art. 14, incisos I; II e; III. Em: BRASIL., Constituição (1988).

${ }^{94}$ COELHO, V. S. P., op. cit., p. 58.

${ }^{95}$ Ibidem, p. 60.
} 
elemento de legitimação popular eleitoral, que não a Constituição, resumindo-se a um corpo aristocrático jurídico. Porém, seguindo os conselhos da abordagem da democracia pragmática, poder-se-ia dizer que é necessário conferir legitimidade a esse poder e, de maneira otimista, no crescente número de audiências públicas e de participação de amicus curiae, analisar uma certa democratização do Poder Judiciário ${ }^{96}$. Ainda assim, há que se olhar com desconfiança para a esfera judiciária em seu caráter de instituição democrática, não se pode esquecer da origem e dos fundamentos do controle de constitucionalidade que teve por base conter os avanços do povo e uma perspectiva popular de poder ${ }^{97}$.

A teoria da democracia pragmática observa as práticas de participação em diversos países, entre eles o Brasil, no intuito de formular uma teoria normativa empiricamente orientada ${ }^{98}$. Entre outras coisas, propõe-se a observar todos os procedimentos decisórios institucionais e tentar conferir ou aumentar a legitimidade desses espaços por meio de mediações entre o processo decisório estatal e o povo ${ }^{99}$. A intenção parece correta e não muito diferente dos objetivos da presente pesquisa, entretanto, a formulação de uma teoria normativa sobre as bases empíricas de um sistema com fortes relações de dominação parece ser facilmente conformada à estrutura existente. Ainda que se fale em avanços, no que se refere à legitimidade democrática em termos do Poder Judiciário, por exemplo, é necessário observar se há reforma estrutural no paradigma dialógico e relacional entre instituição e cidadania. Ou, se as estruturas de participação ocupam apenas os espaços que lhe são concedidos e permitidos pelas estruturas dominantes, no que se poderia chamar de uma tolerância apenas enquanto permissão $0^{100}$, o que talvez fique mais claro após a abordagem teórica dos princípios de justiça a serem incorporados neste trabalho ${ }^{101}$.

96 POGREBISCHI, T., Democracia Pragmática: Pressupostos de uma Teoria Normativa Empiricamente Orientada, p. 681.

97 Ver capítulos 78 a 82 de O Federalista para esclarecimento em relação aos fundamentos iniciais de concepção do Poder Judiciário. HAMILTON; MADISON; JAY., O Federalista. p. 452-485.

98 POGREBISCHI, T. op. cit., p. 672.

${ }^{99}$ Ibidem, p. 676.

${ }^{100}$ FORST, R., Os limites da tolerância, p. 20.

101 Importante dizer que a democracia pragmática rejeita a possibilidade da adoção de teorias normativas contrafáticas ou ideais. Acredita ser possível orientar-se apenas pelas experiências democráticas existente no mundo atual e orientar uma atuação de melhora na qualidade dos processos decisórios e de participação utilizando-se também da perspectiva histórica comparativa. Disso, divirjo na construção do presente trabalho. 
A saúde e os orçamentos participativos são os espaços mais elogiados no Brasil a respeito de uma institucionalidade participativa. A primeira, por meio dos Conselhos de Saúde espalhados pelo país e com grande característica de localidade de políticas públicas ${ }^{102}$, e o segundo, pela forma como foi realizado em alguns municípios e como é visto mundo a fora. Ambos apresentam momentos de melhor performance e realização, mas também podem ser observados com desconfiança no que se refere a possibilidade de implementar reformas de impacto que alterem situações de desigualdade e dominação no Brasil.

As experiências participativas sempre tiveram o caráter de apresentar uma administração pública descentralizada. Nesse sentido, as características das localidades foram extremamente importantes para implementação de políticas de participação e para observação de alterações nas formas de decidir e de construir um pensamento relacionado às políticas públicas. Um dos grandes problemas da participação popular no Brasil é que ela sempre foi associada aos partidos e gestões de esquerda, com forte base no Partido dos Trabalhadores. Dessa forma, há um crescimento na implementação de políticas de participação popular em gestões Petistas, o que setorizou a participação e acabou por gerar pouca aceitação pelos partidos de centro ou centro-direita ${ }^{103}$.

$\mathrm{O}$ orçamento participativo tem seu início e principal expoente na cidade de Porto Alegre, durante a administração do então Prefeito Olívio Dutra. Era possível observar que as áreas de maiores participações eram setores de menor poder aquisitivo e mais carente das políticas públicas no município que se faziam presentes. Dessa forma, a influência sobre o orçamento era capaz de gerar uma alteração nas políticas públicas favorecendo claramente as camadas mais pobres, uma verdadeira implementação dos mecanismos democráticos em oposição ao status quo e contra as disfuncionalidades da representação política formal que permanecia nas estruturas legislativas locais. Vislumbrando uma ideia democrática incapaz de se realizar sem inclusão e justiça social ${ }^{104}$, o orçamento participativo, como mecanismo de participação direta, era capaz - pelo menos em

${ }^{102}$ COELHO, V. S. P., Conselhos de Saúde no Brasil: incluindo os excluídos?, p. 61-66.

${ }^{103}$ AVRITER, L., Impasses da Democracia no Brasil, p. 22.

${ }^{104}$ POGREBISCHI, T., The Pragmatic Turn of Democracy in Latin America, p. 16. 
menores localidades - de mitigar os déficits do modelo exclusivamente representativo e gerar inclusão política e social.

A experiência dos orçamentos participativos foi repetida em diversas cidades do país, obtendo sucesso em alguns casos e ineficiência em outros. Porém, não conseguiu desvincular-se de ser compreendida enquanto política de esquerda. Dessa forma, as alterações nas gestões municipais acabaram por mitigar os impactos transformadores dessa forma política, uma vez que os mecanismos eram abolidos, quando a prefeitura era assumida por partido de oposição ao anterior que implementava o orçamento participativo. A inconstância da política de participação é capaz de desmobilizar uma propensão cultural à participação direta, de forma que, quando reeditados, há, em determinados casos, apropriação dos espaços de participação pelos mesmos que já estão no poder, assim como um afastamento e descrença nos mecanismos enquanto verdadeiramente transformadores das políticas públicas locais ${ }^{105}$.

Em relação aos mecanismos de participação popular na área de saúde, a história não é muito diferente. Observam-se experiências de sucessos e insucessos da participação direta nos Conselhos de Saúde e outros meios de participação direta. Em perspectiva macro, a construção e formação do Sistema Único de Saúde - SUS - já foi uma conquista popular e um pensamento conjunto através de mecanismos de participação direta. Inclusive, foram essas instâncias participativas que possibilitaram o estabelecimento de um sistema de saúde que permitia sua aplicação nas localidades municipais, diminuindo um papel centralizador da União, resguardando para esta apenas a forte participação na distribuição do orçamento dessa área. Nesse sentido, ficavam mais fáceis a implementação e participação popular em reuniões e conselhos de gestão de saúde municipais. O SUS foi estabelecido sobre princípios de equidade e universalização de atendimento, com base no fortalecimento das estruturas de participação e controle popular, havendo, inclusive, a possibilidade de veto às prestações de contas municipais por parte dos Conselhos Municipais ${ }^{106}$. Há um empoderamento

${ }^{105}$ COSTA, F.; CUNHA, A. P. G., Sete Teses Equívocas sobre a Participação Cidadã: o dilema da democracia direta no Brasil, p. 545

${ }^{106}$ COELHO, V. S. P., Conselhos de Saúde no Brasil: incluindo os excluídos?, p. 61. 
institucional conferido à sociedade civil que ganha capital político para demandar políticas e cobrar participação nas decisões.

A experiência da cidade de São Paulo com a gestão descentralizada da saúde pode ser capaz de apresentar fatores positivos e negativos em torno da experiência dos Conselhos Locais de Saúde. Em observação que corrobora a análise relativa aos orçamentos participativos, é possível dizer que a participação popular devia-se muito a propensão dos subprefeitos locais - das diversas localidades nas quais foi dividida a cidade de São Paulo -, havendo uma maior descentralização e uma maior diversificação da participação nos locais onde os subprefeitos eram mais comprometidos com a ideia de participação popular ${ }^{107}$. A própria Vera Schattan Coelho - entusiasta dos Conselhos de Saúde - reconhece que, do ponto de vista de uma análise empírica, seria impossível verificar se a diversificação da participação nos Conselhos de Saúde era mais positiva do que uma participação mais identificada com os agentes públicos responsáveis pelo governo. Porém, o número de participantes, em locais onde havia comprometimento dos agentes públicos com a participação, sempre foi mais elevado do que em localidades onde não havia tal comprometimento. A ausência de reconhecimento, por parte dos cidadãos, do comprometimento do agente público com as instâncias participativas acabava por diminuir a crença no poder de influenciar nas políticas públicas ${ }^{108}$. Portanto, fica claro que há forte dimensão intersubjetiva na relação entre participação popular e agente público; é necessário que o cidadão veja no agente de Estado um reconhecimento de si, enquanto sujeito político capaz de influenciar decisões políticas, para que se sinta motivado a fazer parte dos procedimentos decisórios ${ }^{109}$.

Mas não são apenas os conselhos de saúde e o orçamento participativo que apresentam experiências positivas com a participação popular, gerando um aumento qualitativo da democracia com base numa democracia inclusiva capaz de gerar reconhecimento. A Experiência Federal dos conselhos nacionais foi capaz

${ }^{107}$ COELHO, V. S. P., Conselhos de Saúde no Brasil: incluindo os excluídos?, p. 59

${ }^{108}$ Ibidem, p. 71.

${ }^{109}$ A dimensão intersubjetiva permeia os trabalhos de Habermas, Honneth e Forst, apropriando-se de forte influência hegeliana, no sentido de que o sujeito se reconhece a partir das experiência com o outro de sua comunidade. Perspectiva sobre a qual é construída a teoria de reconhecimento de Honneth. Maiores explicações nos itens abaixo ou em: HONNETH, A., The Struggle for Recognition: The Moral Grammar of Social Conflicts. 
de gerar alto índice de participação das camadas mais pobres e grande influências nas políticas públicas sociais do Governo Federal, durante os governos Petistas. Seria problemático não reconhecer que os mecanismos institucionalizados de participação popular existem, desde administrações anteriores, entretanto, é clara e notória a explosão participativa institucionalizada a partir do governo Lula ${ }^{110}$, o que se perpetuou até, pelo menos, o primeiro mandato do governo Dilma.

Cabe compreender qual o motivo para que a participação popular não tenha se espraiado por todas as áreas de governos federal, estaduais e municipais, reafirmando o comprometimento com uma democracia inclusiva capaz de alterar as estruturas sociais e gerar aproximação e reconhecimento entre classes. Como é possível compreender os altos e baixos dos mecanismos de participação direta?

É possível identificar três fatores que comprometem a fixação de uma cultura participativa na democracia brasileira. O primeiro deles já foi mencionado acima, a implementação de mecanismos de participação direta está associada exclusivamente a gestões governamentais de esquerda. Diante da polarização do cenário federal entre PT e PSDB, as políticas associadas apenas a um dos lados tendem a ser abandonadas, quando a oposição assume o governo, o que é possível observar diante das alternâncias nas gestões municipais e sua relação com a implementação de mecanismos de participação direta. A consequente sazonalidade dessas políticas participativas acaba por desencorajar a participação das camadas mais pobres que se tornam descrentes de sua capacidade de influenciar e transformar os espaços públicos decisórios. É possível identificar uma perda de relevância das políticas participativas, a partir de 2007, o que se deveu a descontinuidade da prática tanto pelo governo federal, quanto pelos governos estaduais e municipais ${ }^{111}$.

O segundo fator está relacionado às áreas estruturais da gestão pública que são tradicionalmente negadas aos movimentos de participação popular, notadamente, a área de infraestrutura e de combate à corrupção ${ }^{112}$. Com base nos numerosos escândalos de corrupção presentes nas manchetes do país, é possível dizer que tratam-se de áreas interligadas, uma vez que o envolvimento sistêmico

${ }^{110}$ POGREBISCHI, T., The Pragmatic Turn of Democracy in Latin America, p. 6.

${ }^{111}$ AVRITZER, L., Impasses da Democracia no Brasil, p. 19.

${ }^{112}$ Ibidem, p. 67. 
de empreiteiras com esquemas de corrupção evidencia essa relação histórica entre Estado e setor privado. Mesmo com o já mencionado avanço da participação direta no Brasil, não há nenhum tipo de estudo que aponte o crescimento ou existência real de participação popular em áreas de infraestrutura e combate à corrupção. Parecem guetos dentro do sistema decisório governamental avessos à participação popular, o que, diante da midiatização de operações da Polícia Federal e Judiciais, acaba aumentando o distanciamento do povo das instituições políticas e gerando um sentimento de descrença nas instituições políticas características do Estado Democrático de Direito no Brasil. O declínio das formas institucionalizadas de participação social, observado após 2007, fica mais claro nas grandes obras de infraestrutura e urbanização, que ocorreram sem qualquer participação social e com violação dos direitos de populações mais pobres ${ }^{113}$. Pode-se analisar, por exemplo, os relatos das audiências públicas em Belo Monte, todas organizadas pela Eletronuclear e marcadas pela grande presença de aparato policial. Havia pouca disposição para o diálogo, enquanto a agência responsável pela publicidade da construção da Belo Monte apresentava gráficos e imagens simuladas que desconsideravam o projeto real e os impactos ambientais e sociais nos locais e populações da região ${ }^{114}$.

Experiências como essas e outras, por exemplo, as desapropriações ocorridas em razão dos megaeventos como a Copa do Mundo e as Olimpíadas, eram desprovidas de participação popular e violavam os direitos das populações residentes nos locais de construção, há décadas ${ }^{115}$. Foi mais que suficiente para que os movimentos sociais comprometidos com as formas institucionalizadas de participação rompessem com o Governo Federal, gerando uma perda da base popular do governo e agravando o problema da governabilidade, principalmente, após as manifestações de 2013. O caráter popular progressista e a agenda positiva das manifestações de 2013 desaparecem do cenário participativo após sua apropriação por instituições da mídia dominante e por alas conservadoras que começam a ocupar mais as ruas, a partir de $2015^{116}$. A consequência da ausência

\footnotetext{
113 AVRITZER, L., Impasses da Democracia no Brasil, p. 60.

${ }^{114}$ SALM, R., Belo Monte: a farsa das audiências públicas.

115 Para maiores informações ver artigo de minha autoria e colegas do grupo de pesquisa em Direito Administrativo da Faculdade Nacional de Direito em 2014. ARAUJO, P. F., et. al.., Desapropriação para Megaeventos no Rio de Janeiro: interesse público de quem?.

${ }^{116}$ AVRITZER, L., op. cit., p. 125
} 
de políticas de participação nas áreas de infraestrutura, afundadas em escândalos de corrupção, dá origem a discursos de intolerância política e seletividade moral que prejudica o traçado de sucesso da participação institucionalizada no Brasil. É bem verdade que não se poderia temer ou questionar a ocupação das ruas por determinada camada social, nesse caso, uma classe média que perdeu privilégios ao longo dos últimos anos dos governos Petistas ${ }^{117}$. Entretanto, a emergência de um discurso seletivo e a troca de uma agenda positiva de reformas, como havia em 2013, por uma agenda negativa de retirada de um partido do poder ou mesmo do discurso "Fora Todos" que só torna a política mais distante do cidadão, são prejudiciais para uma cultura de participação social. Assim, a ascensão de discursos intolerantes no espaço público acaba comprometendo uma construção democrática participativa, uma vez que exclui o diferente da esfera pública.

O terceiro fator acaba por representar uma característica histórica das elites políticas brasileiras: a demofobia. Existe, por boa parte da elite política dominante, uma repugnância à participação popular direta, uma preocupação grande com a possibilidade de que a participação possa alterar os paradigmas atuais do sistema político, comprometendo as posições dos atores que ocupam historicamente as instituições democráticas, principalmente, o Poder Legislativo. Não se pode negar que a preocupação é verdadeira. Como visto acima, os mecanismos de participação popular tendem a alterar o paradigma da democracia representativa, de forma a balançar o status quo dominante e aproximar camadas sub-representadas dos procedimentos decisórios, gerando inclusão. Ainda numa perspectiva histórica já comentada no item anterior, cabe lembrar que a tradição brasileira é de um acordo entre elites para resolver crises e momentos de transição. O povo sempre esteve aquém dos momentos de transição e dos aspectos institucionais decisórios estruturais, o que pode ser evidenciado pela herança de uma institucionalidade capaz de domesticar o poder popular, através das estruturas representativas de dominação.

Interessa agora apresentar, a título exemplificativo, um momento que comprova a perspectiva demofóbica aparente no conflito entre os Poderes

${ }^{117}$ AVRITZER, L., Impasses da Democracia no Brasil, p. 103. 
Executivo e Legislativo. Trata-se da promulgação e posterior suspensão do Decreto que instituiu o Sistema Nacional de Participação Social ${ }^{118}$.

A Política Nacional de Participação Social - PNPS - e o Sistema Nacional de Participação Social - SNPS - foram instituídos através do Decreto n. ${ }^{\circ} 8.243$ de 2015. O Decreto tem como objetivos primordiais a institucionalização e a organização de mecanismos de participação já existentes. Além de trazer as conceituações dos principais mecanismos de participação social, torna-os obrigatórios, na atuação da Administração Pública Federal.

Logo de início, o Decreto deixa claro o seu propósito: "fortalecer e articular os mecanismos e as instâncias democráticas de diálogo e a atuação conjunta entre a administração pública federal e a sociedade civil”. Percebe-se claramente que se pretende, através do diálogo, amplificar a troca de experiências entre a sociedade civil e a Administração Pública Federal. Há um reconhecimento da necessidade de buscar legitimação para a atuação administrativa. Verifica-se, portanto, que o paradigma estabelecido pelo Decreto ultrapassa a legitimidade baseada apenas na relação entre representante e representado, insuficiente para garantir que a Administração expresse uma vontade geral da população, ou seja, um interesse público.

Os objetivos da PNPS, entre outros, são: (i) consolidar a participação social como método de governo; (ii) promover a articulação entre os mecanismos de participação social; (iii) aprimorar a relação do governo federal com a sociedade civil, respeitando a autonomia das partes; e (iv) consolidar a adoção de mecanismos de participação social nas políticas e programas do Governo Federal.

Um dos dispositivos mais relevantes do Decreto, o artigo $5^{\circ}$, estabelece a obrigatoriedade do governo de considerar os mecanismos de participação social na tomada de decisões pela Administração Pública Federal. Não há dúvidas de que esse artigo é um dos mais importantes do Decreto, visto que objetiva garantir a efetividade dos mecanismos de participação social que são estabelecidos anteriormente.

118 As explicações relacionadas à PNPS seguem o capítulo dois de ARAUJO, P. F.; VASCONCELLOS, U.S.C.V., Política Nacional de Participação Social: uma busca pela efetivação do interesse público? 
Em resumo, o Decreto institucionaliza mecanismos de participação popular no âmbito da Administração Pública direta e indireta. Conquanto o Decreto não inove na criação de formas de diálogo com a sociedade, é evidente que apresenta um grande avanço na concretização de valores e princípios constitucionais. Há, ao menos em teoria, um fortalecimento da democracia, trazendo maior eficácia para os processos de deliberação, ao envolver os cidadãos que são nada menos do que a fonte de todo o poder governamental, conforme dispõe o artigo $1^{\circ}$ da Constituição: "todo poder emana do povo".

Ocorre que a maioria da Câmara desaprovou a instituição da PNPS e do SNPS e, logo após a publicação do Decreto pela Presidente Dilma Rousseff, aprovou o Projeto de Decreto Legislativo n. ${ }^{\circ} 1.491$ de 2014 que susta a determinação presidencial. Neste Projeto de Decreto Legislativo, destaca-se sua principal motivação: a alegação de que "o Decreto presidencial corrói as entranhas do regime representativo, um dos pilares do Estado democrático de direito, adotado legitimamente na Constituição Federal de 1988"119. Quando, acrescentando-se à leitura do Decreto, faz-se a leitura do Projeto de Decreto Legislativo n. ${ }^{\circ} 1.491$ de $2014^{120}$, que afirma que as instituições da PNPS e do SNPS representam uma subversão da democracia representativa vigente no Brasil, percebe-se uma verdadeira confusão em relação aos conceitos e paradigmas democráticos, bem como a evidência da demofobia por parte da elite política.

Dessa forma, fica claro porque é possível dizer que a participação direta tem momentos de sucesso e insucesso no Brasil, mas nunca foi verdadeira e completamente incorporada ao procedimento decisório do Estado. Os guetos onde a participação não consegue penetrar, bem como as estruturas de dominação que se arraigam em um sistema político exclusivamente representativo impedem a verdadeira crença numa cultura participativa. É preciso que a defesa de um sistema participativo seja acompanhada de elementos capazes de contestar as estruturas de dominação, com a apresentação das possibilidades de aumento de reconhecimento intersubjetivo, de amplificação do diálogo e do agir comunicativo

\footnotetext{
${ }^{119}$ BRASIL., Projeto de Decreto Legislativo n. 1.491/2014.

${ }^{120}$ O texto final foi aprovado na Câmara determinando a suspensão do Decreto Presidencial que instituiu a PNPS e o SNPS. Em: Idem.
} 
para a formação de estruturas de justificação capazes de tornar o modelo político mais democrático.

\section{3. \\ O Exemplo Brasileiro de Desigualdade e (Não)Reconhecimento Intersubjetivo}

Certamente, este item trata de uma das questões mais caras do presente trabalho. De início, apresenta uma situação de grande desigualdade distributiva no Brasil, também presente em todo mundo. Apesar de haver países com menor situação de desigualdade, é possível afirmar que o problema distributivo de riquezas no mundo é um fator preocupante. Há países emergentes com situações de grandes desigualdades sociais como o Brasil, há países desenvolvidos em que há muita desigualdade social, como os EUA ${ }^{121}$, e outros lugares onde cresce a desigualdade, como na Europa; há países pobres na África, Ásia e nas Américas onde há grande desigualdade e, sobretudo, há uma situação de desigualdade distributiva entre países. Pode-se afirmar que a desigualdade social é uma situação endêmica em todo mundo, de forma que o olhar que se pretende colocar sobre o Brasil não é uma situação isolada. Mas, o cenário brasileiro, em conjunto com o contexto histórico e com a atual crise política, apresenta certas peculiaridades que ajudam ao tratar sobre a democracia e a subjetividade do cidadão.

Ao falar em desigualdade e reconhecimento, é impossível não trazer para a discussão a perspectiva de Fraser em relação aos conceitos de redistribuição e reconhecimento e seu debate com Axel Honneth. Porém, com certa preocupação metodológica e espaço-temporal, é importante estabelecer que a presente pesquisa não pretende formular uma nova teoria sobre reconhecimento com base nas perspectivas do tema desses autores e Forst. Como já dito na introdução, os caminhos democráticos têm por base uma teoria normativa de justificação, em que se deve reconhecer o sujeito como sujeito com direito à justificação, conforme a perspectiva de Forst ${ }^{122}$. Todavia, numa reconstrução do próprio paradigma de reconhecimento do sujeito enquanto sujeito político, diante de um cenário de

${ }^{121}$ GERMANO, F., Desigualdade Social aumenta nos EUA.

${ }^{122}$ FORST, R., Os limites da tolerância, p. 22. 
desigualdades sociais, é impossível não trabalhar com perspectivas de reconhecimento que ampliem o espectro e possam tornar mais claras as ausências e invisibilidades dos sujeitos, num cenário de grande desigualdade social - mas sua utilização é meramente instrumental. Honneth contribui muito para a questão com a separação das dimensões de reconhecimento e Fraser será interessante para aproximar a teoria do conflito de classe em aspecto distributivo.

Sobre esse aspecto, cabe destacar o seguinte: a discussão entre Fraser e Honneth enfrenta aspectos filosóficos em relação à necessidade, ou não, de separar reconhecimento e distribuição, enquanto paradigmas diferentes de uma teoria de justiça. Fraser compreende que a formulação de uma teoria de justiça social deve considerar a cooriginalidade entre reconhecimento e redistribuição, sem confundir os dois como iguais, ou enquanto dimensões um do outro ${ }^{123}$. Podem ser causa e consequência do outro, mas não são a mesma coisa e uma teoria monista que funde completamente os dois paradigmas contribui para a situação em que lutas por reconhecimento geram problemas de distribuição e viceversa $^{124}$. Essa perspectiva se opõe às considerações de Honneth que colocaria a redistribuição enquanto um aspecto do reconhecimento, estabelecendo que todo problema distributivo tem origens ou fortes aspectos de reconhecimento, a priori, principalmente, em uma perspectiva histórica ${ }^{125}$.

Em que pese a qualidade do debate e argumentação de Fraser, parece assistir razão a Honneth quando afirma que a redistribuição seria uma dimensão da luta por reconhecimento e os problemas distributivos são consequência e dimensão de uma ausência de reconhecimento dos sujeitos menos privilegiados ${ }^{126}$. Porém, a noção de cooriginalidade estabelecida por Fraser é interessante para identificar outras dimensões dos aspectos de reconhecimento, principalmente as que envolvem problemas distributivos. Isso porque a autora, de forma didática, separa status e classe, possibilitando a observação de situações práticas onde o aumento de reconhecimento intersubjetivo interfere mais ou menos nos aspectos econômicos distributivos. Ainda assim, não é possível concordar em completo

123 FRASER, N.; HONNETH, A., Redistribution or Recognition: a political-philosophical exchange, p. 19.

${ }^{124}$ Ibidem, p. 76-78.

125 Ibidem, p. 113.

${ }^{126}$ Ibidem, p. 3. 
com a autora, uma vez que a mesma foi incapaz de apresentar uma situação em que o conflito distributivo não fosse gerado por situações predecessoras de ausência de reconhecimento ${ }^{127}$.

Portanto, parte-se de perspectiva política reflexiva de reconhecimento de Rainer Forst, no sentido de que há um princípio normativo da justificação que demanda existir uma relação intersubjetiva em que, de um lado um sujeito é obrigado a fornecer estruturas de justificação para os demais da comunidade e, do outro, existem sujeitos que possuem direito de entender/exigir como justa ou justificável a estrutura normativa, o que inclui as estruturas econômicas distributivas ${ }^{128-129}$. Apesar do princípio de justificação incorporar a discussão relativa aos fatores de poder e dominação existentes na sociedade, enquanto teoria política reflexiva, ele não desce às estruturas reais de situações de desigualdade como a do Brasil. Dessa forma, para não deslocar a linha da presente pesquisa para aspectos de uma abordagem de poder foucaultiana, por exemplo, as noções sociológico-normativas de Honneth e político-pragmáticas de Fraser caem como uma luva para o tratamento do objeto.

De forma político-pragmática, observar as situações de não-reconhecimento existentes em situação de grande desigualdade social, sob a perspectiva de paridade de participação de Fraser, parece aproximar diversas noções de reconhecimento do sujeito enquanto sujeito político com a noção de sujeito com direito à justificação. Na mesma esteira, ao observar a realidade brasileira, é possível verificar a existência de diversos mundos diferentes. Esse ponto, provavelmente, não seria uma interpretação óbvia da obra de Habermas sobre

\footnotetext{
${ }^{127}$ Fraser apresenta diversas situações para ilustrar a separação de reconhecimento e redistribuição, entretanto, ao final, sempre parece terminar no mesmo ponto, onde ambas se encontram. Mesmo nas formulações da autora, salta mais aos olhos que, ainda que se inicie a análise pelos aspectos distributivos exclusivamente econômicos, há sempre um componente de reconhecimento que parece predecessor e mais influente. Mas é justamente esse posicionamento mais complexo relativo às teorias de reconhecimento que não se pretende neste trabalho, interessa verificar as dimensões em que essas três abordagens podem contribuir para o olhar das situações de desigualdade em democracias ocidentais.

${ }^{128}$ FORST, R., The Right to Justification: elements of a constructivist theory of justice, P. 199200.

${ }^{129}$ O princípio da justificação será melhor trabalhando no próximo capítulo. Para as compreensões necessárias deste capítulo é suficiente o que se apresentou, cabendo explicar que o princípio da justificação de Forst nada mais é que um desenvolvimento sobre os princípios (U) e (D) de Habermas originários de sua base Kantiana. Entretanto, ele formula sua teoria da justificação incorporando as estruturas de poder e dominação, o que não é completamente explorado na teoria discursiva procedimental habermasiana.
} 
mundo da vida, enquanto mundo de estranhos, mas é uma abordagem interessante em relação à realidade brasileira ${ }^{130}$. A ideia de um mundo compartilhado por estranhos é insuficiente, diante da ausência de éticas intrassubjetivas na sociedade pós-metafísica ${ }^{131}$, quando parece haver diversos mundos dentro de uma mesma comunidade. A qualificação como estranhos impossibilita a identificação de certos pontos de divergências e distâncias entre os sujeitos de uma sociedade como o Brasil. Na verdade, ao invés de um mundo de estranhos, existiriam diversos mundos que, apesar de se sobreporem e possuírem diversos pontos de interseção, possuem também locais de completa inexistência de contato. É bem verdade que o morador da Zona Sul do Rio de Janeiro entra em contato com a favela diante da proximidade ou da violência que transborda do morro para o asfalto, porém, jamais será capaz de compreender a dinâmica de uma vida naquela comunidade, as constantes tensões diante do domínio do tráfico, as cenas de guerra e terror nos confrontos com a polícia e outras facções, ou até mesmo a morte como fenômeno diário. A melhor interpretação da teoria habermasiana de "um" mundo de estranhos está na característica comunitária das experiências de mundo, ilustrando a figura da sociedade pós-metafísica como diversos mundos separados, com muitos pontos sem contato e não como um mundo compartilhado completamente por sujeitos com características subjetivas diversas. Essa impossibilidade de experimentação da vida do outro, seja entre morro e asfalto, ou entre cidade e áreas pobres da periferia ou do campo, perpetua estruturas históricas de não reconhecimento que interferem diretamente no estabelecimento de uma democracia e, principalmente, na compreensão de que é necessário estabelecer uma estrutura que caminhe para uma perspectiva de paridade de participação e de justificação.

O grande problema é que tanto Forst como Fraser ignoram que essas perspectivas não consideram outros aspectos de reconhecimento que não o de um sujeito político-cultural. A problemática não se insere exclusivamente nos aspectos políticos e culturais e isso fica evidente em países onde há situações de extrema pobreza ou miséria. O problema da paridade de participação e da

\footnotetext{
${ }^{130}$ Mesmo compreendendo que Habermas nunca tenha estabelecido essa abordagem em sua teoria, ao analisar a realidade Brasileira, entendo que seria sim uma interpretação possível do próprio Habermas em relação às grandes divergências estruturais da relação entre os sujeitos.

${ }^{131}$ HABERMAS, J., Pensamento Pós-Metafísico, p. 67.
} 
justificação estariam inseridos apenas na dimensão de estima da teoria de reconhecimento de Honneth, com reflexos na dimensão de respeito enquanto sujeito com direitos - a dimensão legal. Para trabalhar com cenários de grande desigualdade social, é preciso compreender que existem sujeitos que não possuem suas necessidades básicas reconhecidas por outros sujeitos e pelo Estado, agravando e refletindo também nas outras dimensões de reconhecimento. A ausência de reconhecimento quanto às necessidades básicas do sujeito tende a facilitar a perpetuação de estruturas de dominação que imobilizam o sujeito e o impedem de desenvolver sentimentos de amor e respeito próprio, além de autoestima, essenciais para seu desenvolvimento enquanto membro político da comunidade. Por essa razão, de forma didática, ao lidar com as estruturas de grande desigualdade social, será necessário articular as três perspectivas e todas as dimensões do reconhecimento presentes nas obras desses autores ${ }^{132}$.

Descendo do comboio estritamente teórico, as diferentes teorias de reconhecimento servirão para a análise de aspectos sociais e distributivos brasileiros, alguns históricos e outros mais recentes, principalmente no que se refere às alterações dos últimos anos. A ideia é apontar como as estruturas de desigualdade social correspondem a estruturas injustificáveis e de não reconhecimento, o que facilita as estruturas de dominação que impedem um exercício da subjetividade política necessária para uma democracia. Sobretudo, algo que ratifica a noção de que o problema distributivo revela estruturas históricas de não reconhecimento ${ }^{133}$ é a realidade de que a pobreza tem, no Brasil, entre outras coisas, cor $^{134}$.

Apresentando dados básicos dos rendimentos da população brasileira, temse as seguintes porcentagens de um número absoluto (1000 pessoas) de $161.792^{135}$ :

\footnotetext{
132 Apesar do presente trabalho não oferecer uma separação absoluta entre tratamento teórico e empírico (prático), preferi apenas mencionar os conceitos normativos neste primeiro capítulo onde o olhar para o cenário brasileiro toma maior parte. De forma que, as perspectivas de reconhecimento serão articuladas, porém, escolhi desenvolver mais o arcabouço teórico que permite compreender os conceitos de cada autor nos capítulos seguintes, onde a abordagem teórica com algumas perspectivas pragmáticas será mais propositiva.

133 FRASER, N.; HONNETH, A., Redistribution or Recognition: a political-philosophical exchange, p. 114.

${ }^{134}$ COSTA, S., Desigualdades, interdependências e afrodescendentes na América Latina, P. 130.

135 Tabela 7.1.1 em: IBGE., PNAD 2015.
} 


\begin{tabular}{|c|c|}
\hline \multicolumn{2}{|c|}{ Rendimento de pessoas em idade ativa (acima de 15 anos) } \\
\hline Rendimento & Números Relativos (\%) \\
\hline Até 1 salário mínimo & 27,0 \\
\hline Mais de 1 a 2 salários mínimos & 26,4 \\
\hline Mais de 2 a 3 salários mínimos & 9,3 \\
\hline Mais de 3 a 5 salários mínimos & 6,7 \\
\hline Mais de 5 a 10 salários mínimos & 4,3 \\
\hline Mais de 10 a 20 salários mínimos & 1,5 \\
\hline Mais de 20 salários mínimos & 0,4 \\
\hline Sem rendimento (2) & 23,2 \\
\hline
\end{tabular}

Tabela 1.

Dessa visão da pirâmide social brasileira, pode-se ver que a desigualdade social é gigantesca. A maior parte da população em idade ativa ganha até 1 salário mínimo ou não possui qualquer rendimento, representando, em conjunto, 50,2\% da população. Em contraposição, apenas 1,5\% ganha entre 10 e 20 salários e 0,4\% mais de 20 salários mínimos. O topo da pirâmide social brasileira é quase inexistente.

Há ainda uma perspectiva que permite agravar a percepção da concentração de renda no Brasil, baseada em trabalho que parte da noção de que os levantamentos domiciliares tendem a subestimar os rendimentos mais elevados ${ }^{136}$. Isto é, a PNAD estaria quantificando de maneira menor a renda que se concentra nas camadas mais ricas da pirâmide social brasileira. Esses estudos são desenvolvidos há anos, mas ganharam visibilidade após os trabalhos de Thomas Piketty. É bem verdade que somente os dados da PNAD já seriam suficientes para apresentar um cenário de grande desigualdade social, onde há claros problemas de distribuição de renda que se revelam diante de estruturas históricas de não reconhecimento.

${ }^{136}$ MEDEIROS, M.; SOUZA, P. H. G. F.; CASTRO, F. A., O Topo da Distribuição de Renda no Brasil: Primeiras Estimativas com Dados Tributários e Comparação com Pesquisas Domiciliares (2006-2012), p. 7. 
Porém, já que existem outros estudos, observam-se outros dados, baseados nas análises das declarações de imposto de renda de pessoa física ${ }^{137}$. A parte escolhida das análises diz respeito ao que os autores chamam de o "topo da distribuição de renda no Brasil": os 5\% mais ricos da população. Nesse caso, os dados, entre os anos de 2006 e 2012, apontaram que, no Brasil, "o 0,1\% mais rico, recebeu quase $11 \%$ da renda total, o que implica que sua renda média foi quase 110 vezes maior do que a média nacional. O 1\% mais rico, incluindo esse 0,1\%, apropriou-se de 25\%, e os $5 \%$ mais ricos receberam $44 \%$, quase metade da renda total" ${ }^{138}$. Os dados da pesquisa PNAD já são reveladores no que toca o problema de distribuição de renda, mas ao destacar que $5 \%$ da população detêm $44 \%$ da renda total do país, o abismo social que se revela salta aos olhos. Apesar de serem complicadas as comparações, uma vez que bases de dados utilizadas são sempre distintas, em outros países a apropriação da renda pelo $1 \%$ mais rico fica em média entre 10 e $15 \%{ }^{139}$. Os números assustam mais quando sabemos que o $0,1 \%$ brasileiro apropriou-se, no mesmo período, de quase $25 \%$ da renda total dos $5 \%$ mais ricos. Existe desigualdade até entre os mais ricos ${ }^{140-141}$. Sob qualquer defesa que se possa colocar sobre a sociedade capitalista liberal, uma estrutura social-normativa onde $5 \%$ da população abocanham $44 \%$ da renda disponível no país é, por si só, injustificável. Não há como qualificar qualquer estrutura de distribuição de renda desse tipo como justificável ou justa do ponto de vista distributivo.

Para não ficar apenas nos dados distributivos, é importante relembrar que as "desigualdades correspondem a entrelaçamentos entre processos sociais em diferentes níveis geográficos: local, nacional e global"142 e possuem interdependência com diversos fatores de exclusão ligados à raça, à nacionalidade, ao gênero e outros. Para limitação do argumento e identificação da questão com o

\footnotetext{
137 Para melhor entendimento em relação a metodologia de análise, ver artigo completo da nota anterior.

${ }^{138}$ MEDEIROS, M.; SOUZA, P. H. G. F.; CASTRO, F. A. O Topo da Distribuição de Renda no Brasil: Primeiras Estimativas com Dados Tributários e Comparação com Pesquisas Domiciliares (2006-2012), p. 18.

139 Ibidem, p. 18.

140 Ibidem, p. 23.

${ }^{141}$ Apenas é necessário registrar que a PNAD possui base de dados diferente e considera apenas as pessoas com mais de 18 anos, entretanto, para os propósitos ilustrativos que têm os dados empíricos na presente pesquisa, o rigor metodológico das estatísticas deve ser analisado na fonte primária. Veja: Ibidem, p. 12.

${ }^{142}$ COSTA, S. Desigualdades, interdependências e afrodescendentes na América Latina, p. 1.
} 
Brasil, será mais, ou apenas, trabalhado o fator raça ${ }^{143-144}$. Isto é, não é possível cair na análise puramente liberal das desigualdades que associa o insucesso econômico a problemas de conquistas individuais, de forma a negligenciar os fatores excludentes de grupos representados por problemas históricos de reconhecimento $^{145}$. Dessa forma, aproxima-se do argumento de Honneth de que o problema distributivo está relacionado com estruturas históricas de não reconhecimento $^{146}$. Nas palavras de Sérgio Costa, "são necessárias unidades relacionais [intersubjetivas] ${ }^{147}$ capazes de incorporar os diversos fatores (relevantes) que contribuem para conformar as estruturas de desigualdade"148. De fato, é preciso utilizar as características grupais para identificar padrões de desigualdade $^{149}$, que, de forma clara, evidenciam que as estruturas desiguais têm um problema, a priori, de reconhecimento.

Do ponto de vista da raça, enquanto categoria de grupo, a classificação de afrodescendentes é extremamente heterogênea, porque os pretos ${ }^{150}$ integram diversos grupos nas sociedades ${ }^{151}$. Entretanto, existem estruturas semelhantes de desigualdade e um quadro jurídico comum que possibilitam tratar os afrodescendentes conjuntamente, no Brasil e em toda América Latina ${ }^{152}$. Por essa razão, é possível identificar um traçado histórico brasileiro de não reconhecimento dos afrodescendentes de acordo com os regimes de desigualdade ${ }^{153}$ existentes, seriam eles: escravidão, nacionalismo racista, nacionalismo mestiço e regime compensatório. Para exemplificar, destaca-se o mais antigo, onde os pretos eram

${ }^{143} \mathrm{O}$ fator também foi o escolhido por Costa em COSTA, S. Desigualdades, interdependências e afrodescendentes na América Latina, p. 3-4 e p. 132.

144 Apesar de escolher o fator raça, não se pode ignorar que as desigualdades também se relacionam com as características de classes trabalhadoras, gênero, religião e posição de nacional ou imigrante (nacionalidade). Porém, o fator raça ainda parece ser o mais gritante na realidade brasileira. Id., Entangled Inequalities, State, and Social Policies in Contemporary Brazil, p. 2.

${ }^{145}$ Ibidem, p. 1

${ }^{146}$ Vide nota 125.

${ }^{147}$ Adicionei a palavra intersubjetivo para estabelecer a relação entre o argumento de Costa e o de Honneth..

${ }^{148}$ Id., Desigualdades, interdependências e afrodescendentes na América Latina, p. 131.

${ }^{149}$ Id., Entangled Inequalities, State, and Social Policies in Contemporary Brazil, p. 2.

${ }^{150}$ Acima utilizou-se apenas a expressão pretos, uma vez que é a designação que aparece nas pesquisas quantitativas, tais como PNAD e Censo. Retoma-se a palavra afrodescendente, uma vez que o argumento desenvolvido nesses parágrafos é o de Sérgio Costa que utiliza essa designação, sem prejuízo de estar referindo-se a mesma categoria.

${ }^{151}$ Id., Desigualdades, interdependências e afrodescendentes na América Latina, p. 132.

152 Ibidem, p. 133.

${ }^{153}$ Expressão de Costa, para maior entendimento ler artigo completo: COSTA, S., Desigualdades, interdependências e afrodescendentes na América Latina. 
reconhecidos como escravos na estrutura social, enquanto os brancos eram vistos como homens livres. Mesmo após o fim da escravidão no Brasil, feita de forma a não integrar o recém liberto na estrutura social e econômica, segue-se uma guerra contra a negritude que envolve, entre outras coisas, ataques à cultura e à religião ${ }^{154}$. O traçado histórico perpetua uma estrutura de não reconhecimento que se reflete nos dias de hoje em fatores econômicos, sociais, culturais e políticos.

Em média, os afrodescendentes têm expectativa de vida menor, piores condições de vida, educação e limitação ao acesso de serviços públicos, quando comparados ao restante da população ${ }^{155}$. No que se refere às populações mais pobres, no Brasil, os afrodescendentes superam em mais de $50 \%$ o número de brancos ${ }^{156}$, considerando ainda outras categorias raciais. A estrutura evidente de não reconhecimento e desrespeito existente no período da escravidão deve ser conhecida e não pode ser vista como superada ao longo da história. Mesmo hoje, ao categorizar o sujeito como não branco, ainda se correlaciona com uma posição socioeconômica desvantajosa e menos oportunidades de mobilidades ascendentes ${ }^{157}$. Para sair um pouco apenas do exemplo da raça, veja que a renda média das mulheres é cerca de 50\% menor do que a masculina, fenômeno que também aparece na relação entre pretos e brancos ${ }^{158}$. Dessa forma, não fica difícil de estabelecer que pobreza no Brasil tem cor e revela a relação direta entre o problema distributivo de riquezas e camadas historicamente oprimidas às quais, até hoje, nega-se reconhecimento. Ou seja, há um problema histórico de reconhecimento das pessoas pretas, que se revela de forma evidente na estrutura distributiva, no acesso ao mercado de trabalho e na possibilidade de ascensão social. Ao contrário do que diria Fraser, o problema distributivo é, essencialmente, um problema de reconhecimento. Mais uma vez, há uma estrutura normativa injustificável, evidenciada pelo cenário de imobilização social dos grupos não reconhecidos, em uma estrutura de dominação, e uma impossibilidade de considerar equânime a participação, um problema também de paridade de participação.

${ }^{154}$ COSTA, S., Desigualdades, interdependências e afrodescendentes na América Latina, p. 134135.

${ }^{155}$ Ibidem, p. 133

${ }^{156}$ Ibidem, p. 134

157 Ibidem, p. 133.

${ }^{158}$ Conforme análise de Costa de dados do IBGE de 2012 em: Id., Entangled Inequalities, State, and Social Policies in Contemporary Brazil, p. 4. 
No que se refere aos dados da alteração na estrutura social dos últimos anos, é de conhecimento nacional e internacional que os programas de distribuição de renda do Partido dos Trabalhadores, durante os dois mandatos do Presidente Lula e no primeiro mandato da Presidente Dilma, realizaram grandes alterações no combate à pobreza no Brasil. Com base no coeficiente de $G i n i^{159}$ que mede a desigualdade social, o Brasil tem registrado queda da desigualdade nas últimas décadas, com acentuação dessa queda após o ano de 2002, conforme a tabela abaixo $^{160-161}$ : quanto mais próximo de 0 (zero) menor a desigualdade no país.

\begin{tabular}{|c|c|}
\hline \multicolumn{2}{|c|}{ Desigualdade - Coeficiente de GINI 2001-2012 } \\
\hline 2001 & 0,569 \\
\hline 2002 & 0,569 \\
\hline 2003 & 0,560 \\
\hline 2004 & 0,555 \\
\hline 2005 & 0,548 \\
\hline 2006 & 0,545 \\
\hline 2007 & 0,531 \\
\hline 2008 & 0,526 \\
\hline 2009 & 0,521 \\
\hline 2011 & 0,505 \\
\hline 2012 & 0,504 \\
\hline
\end{tabular}

Tabela 2.

Os méritos das políticas de distribuição de renda são inegáveis desde 2002, como dito, há reconhecimento nacional e internacional dos sucessos nas áreas de combate à miséria e da ascensão de diversas pessoas para as chamadas classes $\mathrm{C}$ e D, a nova classe média. Conforme defendido acima, é possível relacionar as

${ }^{159} \mathrm{O}$ coeficiente de GINI recebe críticas de diversas formas quanto ao seu método de análise das desigualdades, mas não há preocupação deste trabalho em tratar da questão metodológica estatística, até porque, há larga aceitação dessa metodologia para analisar desigualdades sociais. Importante apenas ressaltar que o índice registra a desigualdade social do país, não o crescimento, pode ter havido redução da desigualdade social e redução da renda ao mesmo tempo.

${ }^{160}$ Sintetização dos dados em artigo da Folha de São Paulo: CARNEIRO, M.; VETTORAZZO, L., Desigualdade cai no Brasil com todas as classes sociais ficando mais pobres. As tabelas originais da PNAD foram acessadas, porém, escolheu-se pela utilização de informações consolidadas em outros artigos em razão das pretensões deste trabalho não estarem representadas essencialmente em análise de dados estatísticos.

${ }^{161}$ Não inseri na tabela os dados de 2013-2015, uma vez que serão feitas correlações com a análise dos dados das Declarações da Receita Federal que foram consultados apenas até o ano de 2012. Entretanto, o índice de GINI também registrou queda tendo ficado em 0,501; 0,497; 0,491 em 2013, 2014, 2015, respectivamente. 
políticas meramente distributivas realizadas pelos governos do PT com um aumento de reconhecimento dos sujeitos que pertencem a grupos historicamente sub-representados e desrespeitados. É interessante relacionar a inclusão social através de políticas de renda e ações afirmativas com a presença em ambientes anteriores negados aos pretos e mais pobres, como as universidades públicas, através de ações afirmativas, ou mesmo os espaços como aeroportos, shoppings e hotéis ${ }^{162}$. É possível estabelecer ligação dessas políticas com o crescimentos dos coletivos, com a atuação das associações de moradores ${ }^{163}$ e com as demandas populares que inundaram as ruas em 2013 , iniciadas por um movimento que tem maior repercussão na vida dos mais pobres em relação às tarifas de transporte público. E até mesmo verificar a explosão midiática de canais alternativos que passaram a ocupar como protagonistas o espaço virtual, apresentando demandas, visões e perspectivas que não perpassam pela tradicional mídia oligopolizada que defende os interesses dos mais ricos no Brasil ${ }^{164}$. Assim fica, impossível dissociar distribuição de reconhecimento ${ }^{165-166}$.

Há, inegavelmente, um aumento do reconhecimento, seja na dimensão das necessidades básicas com políticas exclusivamente distributivas, seja na dimensão de sujeito enquanto sujeito de direitos nas lutas de movimentos por direito à moradia, como a Associação da Vila Autódromo, que, mesmo derrotada, protagonizou cenário de autoafirmação subjetiva de pessoas com direitos iguais àqueles que pretendiam retirar-lhe a moradia e perante o Estado. $\mathrm{Na}$ dimensão de estima, fica claro que as lutas de camadas sub-representadas têm ganhado cada vez mais espaço enquanto sujeitos políticos de uma sociedade. Além das demandas por reformas políticas, nas manifestações populares de $2013^{167}$, em que

162 AVRITZER, L., Impasses da Democracia no Brasil, p. 103.

163 Há empoderamento de grupos intrinsicamente relacionados às situações de pobreza como mulheres e pretos. COSTA, S., Entangled Inequalities, State, and Social Policies in Contemporary Brazil, p. 10.

${ }^{164}$ AVRITZER, L. op. cit., p. 70-75.

165 POGREBISCHI, T., The Pragmatic Turn of Democracy in Latin America, p. 15.

166 Costa afirma que os novos quadros políticos na América Latina refletem fenômenos de emergência de movimentos negros, o que reafirma a disposição de um autorreconhecimento racial afrodescentende. Em COSTA, S., Desigualdades, interdependências e afrodescendentes na América Latina, p. 133 e 137.

${ }^{167}$ Há grande disputa sobre a interpretação em relação as manifestações de 2013 e a ocupação das ruas que se sucedeu após elas. Aqui tende-se para um amplo reconhecimento daqueles movimentos como um movimento popular que lutava por estruturas estatais diferentes, capazes de representar politicamente o cidadão, em uma análise mais otimista das ruas de 2013 como as de Adriano Pilatti. Porém, em uma análise mais crítica do momento e das cenas que se seguiram, 
todos demandavam melhores estruturas de justificação do processo decisório estatal brasileiro. Nesse sentido, mesmo com as críticas aos impactos do programa de cotas, por exemplo, Costa reconhece sua extrema relevância no âmbito do combate ao racismo, uma forte dimensão do reconhecimento de grupo historicamente desrespeitado ${ }^{168}$.

Todos esses aspectos positivos foram incapazes de realizar uma reforma estruturante na sociedade brasileira, no sentido de que não conseguiram destruir as estruturas de dominação que permanecem historicamente consolidadas e que se revelaram, durante o procedimento de impedimento da Presidente Dilma Rousseff e na agenda implementada pelo governo que assumiu o poder. Uma agenda claramente desconexa da vontade popular e que só aumenta os problemas de distribuição de renda e desigualdade social no país ${ }^{169-170}$. Diante disso, dois importantes fatores podem ser levantados para demonstrar como a distância estabelecida entre as classes no Brasil e as estruturas de dominação têm a capacidade de perpetuar uma normatividade social injustificável e injusta no que toca o reconhecimento intersubjetivo dos mais pobres e os aspectos reflexos da distribuição de renda. Estes fatores são: (i) a propensão que os mais ricos têm de não sofrerem alterações nos cenários de distribuição de renda que existiram nos últimos anos no Brasil; e (ii) a dura reação de uma classe média rebaixada que foi a principal atingida pelas alterações durante as políticas de distribuição de renda $^{171}$.

concordo com a análise de Avritzer que considera o retorno dos movimentos conservadores e antidemocráticos (alguns) às ruas, após uma apropriação de um movimento que, à princípio, começou espontaneamente. É possível confrontar as visões de Avritzer em AVRITZER, L., Impasses da Democracia no Brasil e de Pilatti em PILATTI, A., Entrevista concedida ao IHU Online.

${ }^{168}$ COSTA, S., Entangled Inequalities, State, and Social Policies in Contemporary Brazil, p. 8.

${ }^{169}$ Como exemplo maior podemos citar a já aprovada EC 95 de 2016, BRASIL., EC n. 95/2016. A EC 95/2016 era a anterior PEC 55 no Senado e PEC 241 na Câmara dos Deputados. A EC sofreu duras críticas de diversos setores pela tramitação acelerada e sem diálogo com a população, pela violação ao direito geracional de autodefinição, uma vez que imobiliza o orçamento por 10 anos, prorrogados por mais 10 anos e pelo grande impacto que terá na vida dos mais pobres. Nesse sentido, destaco o pronunciamento de Philip Alston, relator da ONU, conforme notícia no site das Nações Unidas. ONUBR., Brasil: teto de 20 anos para o gasto público violará direitos humanos, alerta relator da ONU.

${ }^{170}$ Aqui, é possível estabelecer relação com o item anterior, onde as políticas de participação direta também foram incapazes de implementar reformas estruturantes. Há uma relação clara entre as políticas de inclusão social e as políticas de participação direta no que se refere aos seus sucessos e insucessos.

${ }^{171}$ AVRITZER, L., Impasses da Democracia no Brasil, p. 103 
Os ricos são menos propensos a se moverem nas alterações da distribuição de renda ${ }^{172}$, essa afirmação se evidencia diante das análises das declarações de imposto de renda de pessoa física e sua comparação com as alterações de classes na base da pirâmide brasileira ${ }^{173}$. Também é relevante que as políticas de transferência de renda executadas durante os governos do PT não repercutiram na esfera de arrecadação tributária em relação aos mais ricos. Ou seja, não houve, efetivamente, transferência de renda de uma camada que abocanha $44 \%$ da renda nacional para os mais pobres e miseráveis ${ }^{174-175}$.

A perpetuação dessa estrutura revela que os ricos permanecem mais capazes de influenciar nas decisões governamentais, uma vez que controlam quase metade da renda existente no país e não houve uma reestruturação tributária capaz de transferir renda do topo da pirâmide para a base; uma ausência completa de paridade de participação. Aparentemente, houve um remanejamento entre as camadas mais baixas da população, no sentido de que o Estado passa a gastar mais com as camadas mais pobres. Assim, não há uma alteração na estrutura de dominação existente no país, ainda que uma diminuição pequena do abismo social tenha sido possível e gerado reconhecimento. Os mais pobres permanecem subrepresentados e carecem de reconhecimento subjetivo em sua dimensão legal e política por parte daqueles que preenchem as esferas decisórias. Ainda que um avanço subjetivo possa ser identificado nas esferas de autorreconhecimento, há pouquíssima alteração entre os diferentes mundos que possuem pontos sem qualquer contato. Para tanto, basta olhar para as constantes negativas do Congresso Nacional em aproximar-se dos mais pobres, nos aspectos decisórios institucionais de participação ${ }^{176}$, assim como da capacidade de lobby de certas

${ }^{172}$ MEDEIROS, M.; SOUZA, P. H. G. F.; CASTRO, F. A., O Topo da Distribuição de Renda no Brasil: Primeiras Estimativas com Dados Tributários e Comparação com Pesquisas Domiciliares (2006-2012), p. 8.

173 Ibidem, p. 25.

${ }^{174}$ VILLAS-BÔAS, M. A., A concentração de renda é maior do que se imaginava.

175 Segundo Costa, políticas sociais teriam maior impacto na diminuição da pobreza, mas seriam menos efetivas para realizar redistribuição sem uma reforma estruturante do sistema tributário. $\mathrm{O}$ que pode ser visto quando as diferenças entre a queda do índice de Gini em países Europeus são muito maiores do que em Latino Americanos após a implementação de políticas sociais de transferência de renda, uma vez que a progressividade dos impostos na Europa é muito maior do que em países Latino Americanos. COSTA, S., Entangled Inequalities, State, and Social Policies in Contemporary Brazil, p. 5-6.

176 Já em 2013 o Congresso rechaçou propostas de plebiscitos ou constituintes exclusivas para tratar da reforma política. Conforme elencado em: BARROCAL, A., As derrotas do plebiscito. Em 2015/2016, durante a crise que culminou no impedimento da Presidente Dilma Roussef, por 
camadas que não têm sofrido cortes com a crise econômica, enquanto áreas caras aos mais pobres foram os principais objetos das novas políticas do governo ${ }^{177}$. Poder-se-ia entender como um problema de paridade de participação e de reformas legais injustificáveis.

Talvez como uma consequência da alteração social apenas na base da pirâmide, há um distanciamento, do ponto de vista de reconhecimento intersubjetivo, - apesar da aproximação em relação a renda - entre classe média alta $^{178}$, que perdeu status social, e camadas mais pobres, que ascenderam em sua posição de renda. Para explicar melhor esse ponto, é importante recuperar a análise de Avritzer em relação à questão.

De fato, com a imobilização das camadas mais ricas nos cenários de redistribuição de renda dos últimos anos, há uma aproximação entre as camadas mais pobres ascendentes e uma classe média que não recebeu nenhum tipo de “privilégio", nesse período. Ao contrário, uma classe média excluída da camada

diversas vezes, a possibilidade de plebiscito foi levantada e rechaçada pelos parlamentares, como evidenciado em declaração do Presidente do Senado à mídia. GARCIA, G., Renan diz que 'não é bom plebiscito para consultar sobre novas eleições.

177 Para evidenciar a questão, selecionei algumas notícias salvas que, em sequência, demonstram como a camada mais pobre sofrerá cortes muito maiores que outros setores da sociedade. Nessa sequência: pela primeira vez em 13 anos, o reajuste do salário mínimo não tem aumento acima da inflação. Disponível em: <http://g1.globo.com/economia/seu-dinheiro/noticia/salario-minimo-naotem-aumento-acima-da-inflacao-pela-1-vez-em-13-anos.ghtml>. Escolhi o reajuste de salário mínimo, porque, nos últimos 13 anos, o reajuste do salário mínimo com base no valor real, acima da inflação, foi considerado o maior acerto no que toca a distribuição de renda e inclusão social. Enquanto isso, Judiciário tem reajuste escalonado de até 41,4\%. Destacando que os salários do Judiciário já figuram entre os dos mais ricos do país. Disponível em: <http://politica.estadao.com.br/noticias/geral,temer-sanciona-reajuste-de-4147-para-servidores-dojudiciario-e-ministerio-publico,10000064087> ou <http://g1.globo.com/politica/noticia/2016/07/temer-assina-reajuste-de-ate-41-para-servidores-dojudiciario-diz-stf.html>. Pode-se ainda levantar os reajustes para o legislativo, executivo e forças armadas, conforme notícias disponíveis em: <http://g1.globo.com/politica/noticia/2016/06/camarainicia-votacao-de-reajustes-de-impacto-bilionario-servidores.html $>$ ou $<$ http://www.valor.com.br/politica/4650397/reajustes-de-militares-e-servidores-do-tcu-saem-nodiario-oficial e http://extra.globo.com/emprego/servidor-publico/reajuste-de-soldos-dos-militareschega-255-19729424.html>. Todas as notícias foram acessadas em 03 de janeiro de 2017. Apenas como medida de rigor acadêmico, é preciso deixar claro que não se faz nenhum juízo de valor se os reajustes eram devidos às categorias que receberam, nem se fez nenhuma pesquisa em relação aos impactos econômicos e tramitação das propostas. $\mathrm{O}$ que as notícias pretendem comprovar é que, o mesmo órgão que diminui os benefícios dos mais pobres, justificando a medida em necessidade de contenção de gastos, autoriza reajustes e aumentos para determinadas categorias que representarão ampliação de gastos. Como justificar essa postura?

${ }^{178}$ A classe média é historicamente definida como o grupo que não faz parte nem do proletariado e nem da burguesia. No Brasil, ela possuía uma característica diferente, ao mesmo tempo que consumia menos bens duráveis e não duráveis do que as classes médias europeia e norteamericana, ela sempre teve acesso a grande número de serviços domésticos baratos por mão-deobra "não qualificada". Em: AVRITZER, L., Impasses da Democracia no Brasil, p. 97 e 99. 
dos 5\% mais ricos manteve-se com sua renda média congelada, o que representou uma maior corrosão pela inflação do período e uma diminuição no poder de compra, principalmente, no que se refere ao mercado de serviços ${ }^{179}$.

O mercado de serviços sofre uma valorização diante da ascensão das camadas mais pobres, principalmente nos serviços domésticos. Há, consequentemente, o aumento nos custos de vida de uma classe média com a consequente aproximação da classe social mais pobre, o que gera uma percepção social extremamente negativa àquela camada ${ }^{180}$. De certa forma, as políticas de inclusão social do governo, representadas, principalmente, no aumento real do salário mínimo e nas ações afirmativas do setor público de educação superior, acabam por retirar espaços da classe média que não pode mais pagar os serviços dos quais utilizava, bem como, não só é obrigada a compartilhar espaços com camadas sociais em ascensão, mas também perde espaço em locais que tinha segurança de manter-se presente ${ }^{181}$.

Nesse momento, pode-se destacar um dos efeitos negativos no reconhecimento causados por políticas de inclusão, há um afastamento de boa parte da classe média decadente em relação aos mais pobres ascendentes. Em realidade, a classe média decadente procura se identificar com as camadas mais ricas e sente-se indignada com a nova disputa de espaço com os pobres. Desse fenômeno poderiam resultar duas consequências, uma positiva e outra negativa. A positiva seria a reflexão de buscar, nessa situação considerada injustificável do ponto de vista normativo, uma resposta em relação à necessidade de exigir que o topo da pirâmide sofresse mais abalos nas políticas de redistribuição, efetivando uma participação ou uma solidariedade na luta por reconhecimento das camadas mais pobres em contraposição às estruturas de dominação que são mantenedoras dos pilares da desigualdade no Brasil. Porém, há, em grande parte, a proeminência dos efeitos negativos, isto é, um movimento conservador que rechaça as políticas de distribuição de renda, ou encontra nelas a causa da crise econômica e política que assola o país. Ocorre que a classe média decadente rompe com sua tradição de apoiar políticas distributivas progressistas, interrompendo um lapso temporal

\footnotetext{
${ }^{179}$ AVRITZER, L., Impasses da Democracia no Brasil, p. 103.

${ }^{180}$ Ibidem, pp. 103-105.

${ }^{181}$ Ibidem, p. 104.
} 
existente desde $1988^{182}$. Não há dúvida, isso simboliza uma verdadeira estrutura de não reconhecimento intersubjetivo entre classes no Brasil.

As estruturas de classe, que possuem não só aspectos econômicos, como raciais e culturais, revelam estruturas de dominação que pretendem negar estruturas de justificação aos mais pobres, revelando uma ausência de reconhecimento em todas as dimensões levantadas por Honneth. Não há dúvida de que esses aspectos aparecem como problemas de paridade de participação democrática, para usar a terminologia de Fraser, o que toca diretamente o objeto da presente pesquisa. Porque são essas estruturas de desigualdade social baseadas na ausência de reconhecimento que comprometem as estruturas institucionais de uma democracia que deveria revelar estruturas intersubjetivas de comunicação e poder, revelando, ao contrário, as estruturas de dominação reforçadas pelo cenário apresentado.

Para encerrar o primeiro capítulo, sintetiza-se que o Brasil é exemplo de como uma má utilização do operador da representação política é capaz de diminuir a qualidade democrática do sistema, afastando o povo das instituições políticas de decisão. Tudo isso cria uma crise de legitimidade que busca a governabilidade em alianças partidárias pouco representativas e não no povo. No Brasil, as experiências de sucesso da participação direta mostram que os espaços de participação popular são capazes de diminuir os déficits do modelo político baseado exclusivamente na representação, aumentando reconhecimento e estruturas de justificação. As áreas de insucesso e a incapacidade das experiências de participação direta de gerarem reformas estruturantes mostram que ainda existem estruturas de dominação, baseadas em situações de não reconhecimento, no cenário brasileiro, que impedem a participação direta de adentrar em determinadas áreas de decisão institucional e que uma teoria capaz de evidenciar essa relação é fundamental. As estruturas de desigualdade social, a ausência de reconhecimento entre classes e as mobilidades ocorridas, nos últimos anos na pirâmide, comprovam como a dominação é capaz de afastar do espaço político os mais pobres, revelando que o problema democrático é um problema de não reconhecimento - em todas as dimensões citadas - refletindo diretamente o cenário distributivo do Brasil. Então, parte-se para a elaboração teórica que possa

${ }^{182}$ AVRITZER, L., Impasses da Democracia no Brasil, p. 105-106. 
desenvolver uma abordagem político-filosófica dos espaços de participação direta como amplificadores do diálogo, redutores dos mecanismos do agir estratégico mantenedor das estruturas de dominação e constituintes de estruturas básicas de justificação. 


\section{2. \\ Discurso, Justificação e Participação Direta}

O capítulo anterior serviu para demonstrar como as estruturas dos modelos democráticos baseados, exclusivamente, na representação têm sido capazes de manter situações de não reconhecimento, perpetuando grandes desigualdades sociais. O operador da representação é usado para afastar o cidadão da política, excluindo o diálogo entre governo e povo das arenas decisórias. Deste cenário, pode-se dizer que há um déficit discursivo no modelo político adotado e uma corrupção do discurso, enquanto característica central de qualquer modelo democrático $^{183}$. O reconhecimento intersubjetivo necessário para um real entendimento entre sujeitos tem sido praticamente inexistente na arena política, de forma que não há real entendimento para justificação das normatividades existentes. Neste capítulo, serão aprofundados dois modelos teóricos capazes de dialogar com as estruturas democráticas: (i) a ética discursiva habermasiana; (ii) e o princípio da justificação de Rainer Forst.

No primeiro item, os conceitos de ação comunicativa, agir estratégico e mundo da vida serão articulados para entender como os mecanismos de participação direta são mais propensos para estabelecer comunicação entre os sujeitos e para reconstituir a importância do discurso no modelo político democrático. De outro lado, entendendo que a representação indireta tem se utilizado do agir estratégico para estabelecer estruturas de dominação, desprezando o reconhecimento intersubjetivo comunicativo necessário para uma vida em sociedade. Para isso será necessária uma abordagem da teoria comunicativa de Habermas, tocando pontos cruciais de uma sociedade baseada em uma ética de linguagem comunicativa.

Em seguida, o princípio da justificação aparece como princípio normativo capaz de demarcar as bases para a introdução do discurso e da comunicação no modelo democrático. Dessa forma, procura-se determinar como os mecanismos de participação direta podem fornecer estruturas de justificação melhores que as (in)existentes nos modelos democráticos exclusivamente representativos. A

${ }^{183}$ WARREN, M. E., Deliberative Democracy and the Corruption of Speech, p. 6. 
articulação desse princípio vem do trabalho de Rainer Forst que tem fortes bases na teoria comunicativa de Habermas, uma vez que o princípio da justificação também articula uma necessidade de entendimento intersubjetivo.

Fica interessante pensar no princípio da justificação de Forst como aprimoramento do princípio (D) de Habermas $^{184}$, uma vez que o princípio normativo de Forst nada mais é do que um aperfeiçoamento dos princípios discursivos democráticos habermasianos, trabalhando-os articuladamente. A teoria do reconhecimento de Honneth aparecerá também neste capítulo, já que o autor aprofunda melhor as bases normativas sociológicas do reconhecimento, de forma que, sem ela, não seria possível trabalhar as ideias de reconhecimento intersubjetivo discursivo e de instrumentos para um reconhecimento intersubjetivo necessários para estabelecer estruturas básicas de justificação. É importante ressalvar que não se faz uma opção filosófica entre a ética do discurso e a ética do reconhecimento, a ideia é utilizar as ferramentas fornecidas por autores de uma mesma tradição.

Seguindo a linha metodológica do trabalho de não separar teoria e prática, apesar da forte marca teórica que este capítulo pretende apresentar, haverá também exemplificações e observações empíricas capazes de fortalecer os argumentos teóricos que serão apresentados. Algumas vezes, serão apresentadas observações sobre acontecimentos reais, em outras, poderão ser trabalhadas situações hipotéticas. Essa estratégia, por diversas vezes, é marca dos trabalhos dos autores aqui utilizados.

\section{1. \\ Participação Direta: Relação entre Agir Comunicativo e Agir Estratégico}

Antes de mais nada, é preciso estabelecer que, quando se fala em participação direta, está se falando do exercício direto do poder de decisão ou de influenciar decisões políticas pelo sujeito político, sem intermediário, enquanto

\footnotetext{
${ }^{184} \mathrm{O}$ princípio (D) é assim ementado: "são válidas as normas de ação às quais todos os possíveis atingidos poderiam dar o seu assentimento, na qualidade de participantes de discursos racionais". HABERMAS, J., Direito e Democracia: entre faticidade e validade, V. I., p. 142.
} 
cidadão, dentro do sistema democrático existente em sua sociedade. Trabalha-se com um conceito amplo dessas arenas de participação direta ${ }^{185}$ que podem estar em ações meramente fiscalizatórias, ou em interações por meio de ações demonstrativas, como protestos públicos - desde que haja interlocução com o governo -, como podem estar em mecanismos institucionalizados de participação direta, como audiências públicas e conselhos populares, entre outros. Tratam-se de locais de amplificação discursiva, onde o sistema político busca aumentar sua qualidade democrática, através do diálogo, já que essa seria sempre a melhor forma de solução de $\operatorname{conflitos}^{186}$. Não é difícil de afirmar que o poder político do povo deve ser identificado no poder comunicativo do cidadão ${ }^{187}$.

O argumento será desenvolvido para defender que os locais de participação direta proporcionam melhores espaços para ações comunicativas orientadas para entendimento ou são arenas, onde seria mais fácil combater um agir estratégico. Ao contrário do que ocorre nas interações entre governo e povo, em modelos puramente representativos, em que se perpetuam estruturas de agir estratégico que significam estruturas de dominação contrárias a uma ética discursiva capaz de gerar acordos e entendimentos, dando continuidade para situações de não reconhecimento. Para compreensão do argumento, é necessário iniciar pelo ponto da Teoria Comunicativa de Habermas em que se explica a diferença entre o agir comunicativo e o agir estratégico.

A insuficiência das teorias contratualistas, que compreendem a sociedade a partir de um pacto pressuposto para a constituição de um soberano, que cumpra determinadas obrigações, é o ponto de partida de Habermas para buscar uma ética baseada na comunicação ${ }^{188}$. A vida em sociedade não existiria por um acordo tácito de conferir poder a um ente superior capaz de garantir a segurança de todos os membros da sociedade para superação de um hipotético estado de natureza; não

\footnotetext{
${ }^{185}$ Interessante a abordagem sistêmica da democracia deliberativa que propõe Mansbridge na introdução do livro que organiza: Deliberative Systems. A ideia do livro é articular as diversas arenas de deliberação capazes de influenciar na qualidade da democracia, sejam elas mais ou menos representativas. MANSBRIDGE, J. et al.., A systemic approach to deliberative democracy. ${ }^{186}$ WARREN, M. E., Deliberative Democracy and the Corruption of Speech, p. 5.

${ }^{187}$ SANTOS, F. F. F., A Teoria Discursiva Habermasiana e o Exercício da Cidadania Fiscal, p. 78. ${ }^{188}$ HABERMAS, J., The Theory of Communicative Action: Reason and the rationalization of society. V. 1, p. 283.
} 
seria essa a origem da sociedade ${ }^{189}$. Na verdade, a vida em sociedade seria a possibilidade de ações coordenadas por acordos racionalmente motivados, o que só aconteceria com base em ações orientadas para o entendimento ${ }^{190}$.

Os modelos contratualistas modernos só seriam suficientes para desenvolver uma ideia de consenso normativo básico, sob o qual funcionavam apenas as sociedades primitivas. Quando se fala em sociedades desenvolvidas, não há mais um consenso normativo básico metafísico ou transcendental, que ocorre através da interação sistêmica de ações funcionais ${ }^{191}$. As justificativas baseadas apenas nas narrativas metafísicas não são mais suficientes para explicar uma sociedade plural desenvolvida. As justificações só podem ser compreendidas pela dissolução de uma "síndrome de validade" que necessita da linguagem para se implementar e que relativiza os conceitos de religião e metafísica ${ }^{192}$.

A negativa de Habermas ao estado de natureza hipotético vai orientá-lo para a busca de uma situação - por princípio não hipotética - necessária para a formação das ações coordenadas sem as quais não se poderia falar em sociedade. Não parece que o autor obtém total sucesso, nessa tarefa, já que toda ação comunicativa habermasiana tem por base a pressuposição da existência de um background histórico-cultural, capaz de formar bases comuns de linguagem que orientem os participantes (locutor e interlocutor) dos atos de fala em seus posicionamentos discursivos ${ }^{193}$. Seria no compartilhamento de um Mundo da Vida Comum, com experiências histórico-culturais e vivências partilhadas, que existiria esse acordo em relação aos significados possíveis de se atribuir aos atos de fala. Veja que, para fugir de uma situação hipotética de violência, tal qual o estado de natureza hobbesiano, Habermas precisa assumir, como pressuposto, um acordo em relação aos significados linguísticos que orientam a convivência no mundo da vida, seria uma espécie de pressuposto normativo básico de linguagem.

189 "Diferentemente da construção individualista, jurídico-racional do estado de natureza, a forma de organização das associações livres é um conceito sociológico que permite pensar relações que surgem espontaneamente e livres de coerção de uma maneira não contratualista." HABERMAS, J., Soberania Popular como Procedimento: um conceito normativo de espaço público, p. 107.

${ }^{190}$ Id., The Theory of Communicative Action: Reason and the rationalization of society. V. 1, p. 274.

${ }^{191}$ Id., The Theory of Communicative Action: The Critique of Functionalist Reason. V. 2, p. 115.

192 Id., Pensamento Pós-Metafísico, pp. 43-44.

193 Id., The Theory of Communicative Action: Reason and the rationalization of society. V. 1, p. xli. 
Retirando-se dessa arena conturbada de discussão entre necessidade de um estado de natureza, ou de um preexistente conhecimento linguístico para a comunicação, o que interessa é a compreensão em relação ao agir comunicativo e aos atos de fala. Para Habermas, a necessidade de coordenar as ações no mundo da vida, obriga os participantes a entrarem em processos discursivos de atos de fala que sejam capazes de gerar acordos racionalmente motivados ${ }^{194}$. É necessário que haja compreensão da linguagem falada, capaz de construir um nível de comunicação necessário para as ações coordenadas na sociedade ${ }^{195}$. Nessa perspectiva, já se identifica um dos grandes problemas dos sistemas exclusivamente representativos, a supressão ou redução dos encontros entre governo e povo, havendo menos possibilidades da formação de processos discursivos.

As conexões empíricas sociais só podem ser observadas com a distinção de mecanismo de ações coordenadas que harmonizam as formas de ação dos participantes para os mecanismos que estabilizam interconexões não intencionais de ação. No primeiro caso, há um consenso normativo alcançado pela comunicação, no segundo, um consenso atingido por uma regulamentação não normativa de decisões individuais ${ }^{196}$. O mais importante nos processos discursivos é a busca do entendimento entre os participantes.

Nesse sentido, a compreensão dos enunciados se revela na forma pela qual "locutor e interlocutor compreendem os sentidos das frases quando sabem sob que

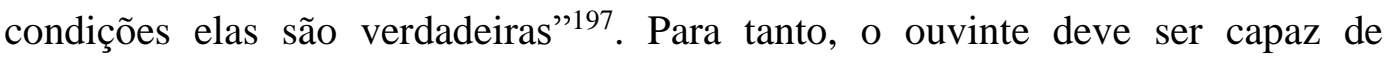
compreender não só a expressão mas também a intenção do agente ${ }^{198}$. Haveria comunicação diante de um entendimento intersubjetivo em relação aos significados e intenções de um discurso, sendo necessário que haja uma intenção

\footnotetext{
194 Apesar das diversas problemáticas possíveis de se levantar em relação ao conceito de acordo racionalmente motivado, prefiro permanecer com o ponto de Habermas, que será retomado em Forst, da necessidade dos espaços de troca de razão. A abordagem de Forst parece mais apropriada para as estruturas existentes, entretanto, é necessário contemplar a perspectiva de Habermas para um melhor entendimento dos conceitos de agir comunicativo e agir estratégico.

${ }^{195}$ HABERMAS, J., The Theory of Communicative Action: Reason and the rationalization of society. V. 1, p. 274.

${ }^{196}$ Id., The Theory of Communicative Action: The Critique of Functionalist Reason. V. 2, p. 117.

${ }^{197}$ Id., The Theory of Communicative Action: Reason and the rationalization of society. V. 1, p. 276.

${ }^{198}$ Ibidem, p. 274-275.
} 
primitiva do locutor para tal ${ }^{199}$. Da mesma forma, torna-se necessário que todos assumam papéis de interlocução, isto é, sejam, ao mesmo tempo, falantes e ouvintes. Somente nessa relação mútua é possível compreender o agir comunicativo $^{200}$. Nas palavras do próprio autor:

Por um lado, os indivíduos se encontram, desde sempre, inseridos num mundo estruturado, e aberto pela linguagem e alimentando-se dos contextos de sentido gramaticalmente preconcebidos. Nesta medida, a linguagem afirma-se perante os sujeitos falantes como algo pré-existente, e objetivo, como a estrutura marcante das condições de possibilidade. Por outro lado, o mundo da vida, aberto e estruturado pela linguagem, só ganha consistência na prática de entendimento de uma comunidade linguística. Ao mesmo tempo, o estabelecimento de consensos linguísticos, através dos quais as interacções se entrelaçam no espaço e no tempo, mantém-se dependente das tomadas de posição autónomas do estilo sim/não dos participantes de uma comunicação face a pretensões de validade criticáveis.

[...]

Entre o mundo da vida, enquanto recurso ao qual vai beber o agir comunicativo, e o mundo da vida enquanto produto desse agir, vai-se estabelecendo um processo circular, em que o sujeito transcendental desaparecido não deixa atrás de si qualquer lacuna. ${ }^{201}$

Articulando perspectivas de Austin, Bühler, Wittgenstein, entre outros ${ }^{202}$, Habemas vai entrar no terreno da teoria da linguagem para desenvolver as estruturas capazes de compor o agir comunicativo. Com a divisão de Austin de atos locutórios, ilocutórios e perlocutórios, o autor avança no sentido de que os primeiros dizem respeito apenas ao "dizer algo", enquanto os segundos relacionam-se com uma ação conectada aos atos de fala e, por fim, os atos perlocutórios têm necessária representação com os fins que pretendem atingir através dos atos de fala ${ }^{203}$.

Nos atos de fala ilocutórios, a ação do locutor é sempre orientada para o entendimento. Isso não significa que inexistam efeitos perlocutórios colaterais, mas veja que esses efeitos são diferentes da ação perlocutória em si. Na ação perlocutória, há sempre uma assimetria necessária em relação ao conhecimento

199 HABERMAS, J., The Theory of Communicative Action: Reason and the rationalization of society. V. 1, p. 280.

${ }^{200}$ Id., Pensamento Pós-Metafísico, p. 50.

${ }^{201}$ Ibidem, p. 67.

${ }^{202}$ Como dito na introdução, neste trabalho não há qualquer compromisso com as leituras destes autores. As limitações espaço-temporais de uma pesquisa de mestrado e o objeto que se propõe impedem que se vá mais além nas leituras desses autores do que através da reconstrução do próprio Habermas; até mesmo porque, o aprofundamento de cada autor utilizado por Habermas em sua teoria reconstrutivista já daria cabo de uma vida inteira de pesquisas. A releitura habermasiana desses autores é o que me interessa para o desenvolvimento desta pesquisa.

${ }^{203}$ Id., The Theory of Communicative Action: Reason and the rationalization of society. V. 1, p. 289. 
dos fins desejados, porque apenas o locutor conhece os fins que pretende atingir e não os informa ao interlocutor. Enquanto nos efeitos perlocutórios que podem existir em ações ilocutórias, quando estão dentro do agir orientado para o entendimento, fica claro que, sempre que for possível atribuir ao locutor uma intenção inexistente, o mesmo deve se posicionar fornecendo explicações ou negativas para retirar a falsa intenção que sobre ele recairia e não permitir que o interlocutor se sinta desapontado ou traído ${ }^{204}$.

Efeitos perlocutórios são resultados de ações teleológicas, intencionadas dentro de um determinado estado de coisas trazido por uma intervenção no mundo. Ao contrário, os resultados ilocutórios são alcançados em uma relação interpessoal de participantes em comunicação para um entendimento, sobre algo dentro do mundo 205 . É fácil compreender que a busca pela comunicação necessária para a coordenação de ações constitutiva de um corpo social só pode ocorrer através da utilização de atos de fala ilocutórios.

Dessa breve noção adotada por Habermas ${ }^{206}$, já é possível identificar o agir comunicativo como aquela ação que busca o entendimento entre locutores e sujeitos ativos capazes de produzir consensos, utilizando-se sempre de atos de fala ilocutórios ${ }^{207}$. Nos atos ilocutórios, é sempre possível identificar a intenção do agente, porque ele diz exatamente o que pretende, ou seja, a ação comunicativa pressupõe que o falante deixa claro quais são os fins que pretende atingir, no próprio conteúdo dos enunciados que emite 208 . Como aponta Warren, na maior parte das democracias, os governos funcionam sob um grande clima de descrença e quase todas as tratativas ocorrem de forma não transparente, com as negociatas e intenções dos agentes públicos resguardadas entre quatro paredes ${ }^{209}$. Há, nesse ponto, que se fazer uma leitura da realidade política com base na teoria de Habermas, isto é, estariam os discursos políticos de agentes do Estado utilizandose de atos de falas ilocutórios ou perlocutórios? Na perspectiva de Warren, há uma

\footnotetext{
${ }^{204}$ HABERMAS, J. The Theory of Communicative Action: Reason and the rationalization of society. V. 1, p. 293-295.

205 Ibidem, p. 293.

${ }^{206}$ As classificações dos atos de fala possuem variações mais densas do que as apresentadas neste trabalho. Entretanto, para as noções de agir estratégico e agir comunicativo que se utilizará, as explicações feitas são suficientes para o entendimento.

${ }^{207}$ HABERMAS, J., op. cit., p. 286-287.

208 Ibidem, p. 290.

${ }^{209}$ WARREN, M. E., Deliberative Democracy and the Corruption of Speech, p. 3
} 
corrupção do discurso, enquanto meio de comunicação entre governo e povo. Assim, pode-se responder que os atos perlocutórios têm corroído a estrutura discursiva do Estado. Afinal, corrupção significa dizer que as pessoas utilizam o discurso apenas de maneira estratégica ${ }^{210}$.

Avançando, Habermas também diz que é necessário estender a teoria de comunicação de Weber para compreender uma noção reflexiva relacional com base na atuação para o entendimento de forma recíproca ${ }^{211}$. Os participantes das interações não podem perseguir fins distintos da comunicação e do entendimento. Justamente porque a ação - agir - comunicativa é uma ação social orientada primordialmente para atingir o entendimento ${ }^{212}$. Nas palavras do autor:

Eu só devo chamar de ação comunicativa, quando os agentes envolvidos estão coordenados não por cálculos egocêntricos de sucesso, mas por atos de alcançar o entendimento. $\mathrm{Na}$ ação comunicativa, os participantes não estão primeiramente orientados para o próprio sucesso individual; eles perseguem objetivos individuais sob a condição de que podem harmonizar seus planos de ação com base em definições comuns de uma situação. Nesse sentido, a negociação das definições de determinada situação é um elemento essencial das conquistas interpretativas necessárias para uma ação comunicativa $^{213}$.

Atingir um entendimento significa que os participantes da comunicação alcançam um acordo em relação a validade de um enunciado; o acordo é o reconhecimento intersubjetivo da alegação de validade que o locutor levanta ${ }^{214}$

Uma vez que é necessário um acordo em relação a validade dos enunciados emitidos em um processo discursivo, deve ser possível que os participantes possam rejeitar as pretensões de validade dos enunciados. Ou seja, em qualquer contexto de ação comunicativa, é necessário que o interlocutor possa rejeitar o enunciado de três formas: (i) contestando a correção do enunciado, diante do complexo normativo envolvido; (ii) criticando a veracidade subjetiva que o locutor insere no enunciado, em relação a conteúdos e a experiências que só ele

\footnotetext{
${ }^{210}$ WARREN, M. E., Deliberative Democracy and the Corruption of Speech, p. 8-9.

${ }^{211}$ HABERMAS, J. The Theory of Communicative Action: Reason and the rationalization of society. V. 1, p. 280.

212 Ibidem, p. 285.

213 Tradução livre. No original em inglês: "I shall speak of communicative action whenever the actions of the agents involved are coordinated not through egocentric calculations of success but through acts of reaching understanding. In communicative action participants are not primarily oriented to their own individual successes; they pursue their individual goals under the condition that they can harmonize their plans of action on the basis of common situation definitions. In this respect the negotiation of definitions of the situation is an essential element of the interpretive accomplishments required for communicative action." Ibidem, p. 285-286.

${ }^{214}$ Id., Pensamento Pós-Metafísico, p. 120.
} 
tem acesso; (iii) negando os pressupostos fáticos de que o locutor pretende uma declaração de entendimento com esse enunciado ${ }^{215}$. No primeiro caso (i) a contestação é contra a própria veracidade do enunciado no que toca o consenso normativo básico em relação aos significados linguísticos. A segunda negativa (ii) refere-se à possibilidade de que o locutor esteja utilizando experiências pessoais que não seriam verdadeiras ou coerentes com o enunciado que se pretende comunicar. Já na terceira forma de rejeição (iii), fala-se da própria intenção do agente; o interlocutor identifica que o locutor não pretende a comunicação através de seu enunciado, utilizando-se apenas de atos de fala perlocutórios sem qualquer qualidade ilocutória.

De tudo isso, resta dizer que o mais importante na comunicação é a possibilidade do ato de fala ser criticável, a princípio. Compreender uma sentença é saber quando o falante tem boas garantias de que as condições de validade de sua afirmação se implementam. É necessário que haja um posicionamento crítico do interlocutor, para que se estabeleça uma ação intersubjetiva de comunicação ${ }^{216}$. Sem a possibilidade de criticar o enunciado, não há intersubjetividade no processo discursivo entre dois sujeitos. É só através da estrutura de comunicação ilocutória que se pode dizer capaz de estabelecer relações intersubjetivas ${ }^{217}$. Nesse ponto, retorna-se à teoria do reconhecimento. É bem verdade que a intersubjetividade necessária para um processo discursivo é produtora e consequência da existência de reconhecimento intersubjetivo entre os sujeitos ${ }^{218}$, ainda que Honneth possa rejeitar que haja experiência moral em situações discursivas ${ }^{219}$.

Dizer que são relações intersubjetivas de comunicação é explicitar que um ator depende do outro para desenvolver seu plano de ação de forma interativa, o ego depende do alter. São essas as formas de interações mediadas pela linguagem. No agir comunicativo, "a força estabelecedora de consensos do entendimento linguístico, isto é, as energias vinculativas da própria linguagem actuam em prol

215 HABERMAS, J., The Theory of Communicative Action: Reason and the rationalization of society. V. 1, p. 307.

${ }^{216}$ Ibidem, p. 318.

${ }^{217}$ Ibidem, p. 320.

${ }^{218}$ Sobre esse ponto retornarei com melhores explicações durante o tratamento do princípio de justificação de Rainer Forst.

219 FASCIOLI, A., O Reconhecimento como Núcleo de Fundamentação da Normatividade: reflexões sobre a crítica de Honneth à ética do discurso habermasiana, p. 52. 
da coordenação de acções". Enquanto, no agir estratégico, “o efeito coordenador permanece dependente da influência, levada a cabo por intermédio de atividades não linguísticas, dos actores sobre a situação da acção ou sobre os seus semelhantes"220-221.

Já introduzidas algumas questões referentes ao agir estratégico, cabe mais alguns detalhes para fixar a noção que serve como base para a defesa do argumento de que a relação entre governo e povo deve ser orientada para o entendimento $^{222}$, com o mínimo possível de ações estratégicas, o que não parece ocorrer. O agir estratégico é a ação social orientada apenas para o sucesso individual e não para atingir o entendimento, ele segue aspectos de escolha racional e observa a eficiência de influenciar decisões de um oponente racional, sem lhe garantir todas as condições necessárias para rejeitar os enunciados colocados $^{223}$.

Quando uma ação é orientada para o sucesso, utilizando, apenas instrumentalmente o discurso, há uma ação estratégica ${ }^{224}$. Na ação estratégica, uma parte age com orientação para o sucesso e deixa a outra acreditar que há ações orientadas para o entendimento ${ }^{225}$; para isso o interlocutor precisa ser mantido nas sombras em relação às intenções do agente. As pretensões de validades são retiradas para a colocação de pretensões de poder, no máximo, há a possibilidade de cumprimento de uma linguagem informativa sem qualquer capacidade de produzir entendimento. Na verdade, há substituição das condições

\footnotetext{
${ }^{220}$ HABERMAS, J., Pensamento Pós-Metafísico, p. 84.

221 "Se partirmos da utilização não comunicativa de um saber proposicional em acções teleológicas, acabamos por deparar com o conceito da racionalidade orientada para fins - tal como foi elaborado na teoria da escolha racional. Se partirmos da utilização comunicativa de um saber proposicional nos actos de fala, acabamos por deparar com um conceito de racionalidade próprio do entendimento que pode ser clarificado, no âmbito da teoria do significado, com base nas condições de aceitabilidade de actos de fala". Ibidem, p. 83

222 "[...] o discurso público tem de fazer a mediação entre a razão e vontade, entre a formação de opinião de todos e a formação da vontade majoritária dos representantes do povo". Id., Soberania Popular como Procedimento: um conceito normativo de espaço público, p. 103.

${ }^{223}$ Id., The Theory of Communicative Action: Reason and the rationalization of society. V. 1, p. 285.

${ }^{224}$ Ibidem, p. 289.

${ }^{225}$ Ibidem, p. 332.
} 
de interlocução por condições sancionatórias que substituem as condições normativas da ilocução ${ }^{226}$.

A diferença conceitual entre o agir comunicativo e o agir estratégico é sempre gritante. A busca pelo entendimento procura uma coordenação de ações bem sucedidas que não utilizam a racionalidade apenas para fins. É preciso que o interlocutor compreenda os objetivos do locutor e tenha para si a existência de um fim maior de comunicação, só assim, é possível falar em um consenso linguístico comunicativo $^{227}$. Importante destacar aqui que não se trata de um consenso material sobre valores metafísicos ou normalizadores da sociedade. Fala-se de um consenso linguístico de entendimento intersubjetivo, ou seja, o eu precisa reconhecer no outro uma subjetividade com direito e capacidade de participar consigo de um processo discursivo orientado para o entendimento; isso só é possível se falarem a mesma linguagem. Envolvem-se questões de autodeterminação, autorrealização e reconhecimento intersubjetivo que dependem da reciprocidade de reconhecimento dos participantes como sujeitos comunicativos de uma sociedade formada por ações coordenadas de entendimento:

No agir comunicativo, as pressuposições da autodeterminação e da autorrealização mantêm um sentido estritamente intersubjectivo: quem julga e age moralmente, tem de poder contar com o assentimento de uma comunidade comunicativa ilimitada e quem se realiza numa história de vida assumida de forma responsável tem o direito de poder contar com o reconhecimento dessa mesma comunidade. Nesta conformidade, a minha identidade, nomeadamente, a minha autocompreensão como um ser individuado que age de forma autónoma, apenas pode estabilizar-se se eu for reconhecido como pessoa e como esta pessoa. Sob as condições do agir estratégico, o si-mesmo da autodeterminação e da autorealização sai do âmbito das relações intersubjetivas. Quem age de forma estratégica, já não se reporta a um mundo da vida partilhado a nível intersubjetivo; tendo ele próprio, por assim dizer, perdido o seu enquadramento no mundo, ele defronta-se com o mundo objetivo e decide-se unicamente com base em preferências subjectivas. Neste acto, não depende do reconhecimento por parte de outros. A autonomia transforma-se então numa liberdade arbitrária, e a individuação do sujeito socializado, no isolamento de um sujeito libertado que se possui a si mesmo ${ }^{228}$.

\footnotetext{
${ }^{226}$ Id., Pensamento Pós-Metafísico, p. 88. Ou ainda: "Uma acção latentemente estratégica fracassa, mal o destinatário descubra que o seu adversário apenas fingiu interromper a sua orientação para o êxito. No agir estratégico, altera-se a constelação do falar e agir. Aqui enfraquecem as forças de ligação ilocutórias; a linguagem reduz-se a um simples meio de formação." HABERMAS, J., Pensamento Pós-Metafísico, p. 87

${ }^{227}$ Ibidem, p. 85.

${ }^{228}$ Ibidem, p. 229.
} 
Tendo tudo isso por base, seria óbvio dizer que para se falar em democracia é necessário que se fale também em comunicação, suprimir o processo discursivo da arena democrática é suprimir a própria democracia ${ }^{229}$. Antes de avançar nesse ponto mais pragmático, há mais um aspecto da ação comunicativa a se explorar, que tem por referência a normatividade básica linguística necessária para o entendimento.

Habermas diz que: "[...] ação comunicativa depende de contextos situacionais, que representam segmentos do mundo da vida onde há interação dos participantes" ${ }^{230}$. Dessa afirmação podem-se retirar duas abordagens importantes, a primeira significa que a ação comunicativa é típica do mundo da vida e não dos sistemas financeiros e do dinheiro; a segunda abordagem toca algo já levantado no capítulo anterior: a possibilidade de existirem diferentes mundos da vida em uma mesma sociedade.

No que toca ao sistema financeiro do dinheiro e do mercado, Habermas entende que ali é somente o agir estratégico que orienta uma escolha racional onde deve haver funcionalidades necessárias para uma operação regulada do sistema. Isto porque o agir comunicativo é impossível na negociação mercadológica que envolve sempre uma orientação para fins individuais e supressão de informações do interlocutor, de quem se quer obter vantagem ${ }^{231}$. Há então uma incompatibilidade entre sistema e mundo da vida, onde, em um prevalece o agir estratégico, e em outro o agir comunicativo. Ao mesmo tempo, o autor afirma que "uma sociedade integrada em associação, ao inverso de mercados, seria uma ordem política e, não obstante, livre de coerção" ${ }^{\text {232. }}$. Quer dizer que a política depende do modelo e condições de funcionamento do poder comunicativo, porque isso o torna eficaz indiretamente, com a limitação do poder administrativo de fato $^{233}$.

Quando escrevo, nesta pesquisa, sobre as arenas políticas de tomadas de decisão, estou tratando de um espaço em constante disputa entre o agir

\footnotetext{
${ }^{229}$ WARREN, M. E., Deliberative Democracy and the Corruption of Speech, p. 20.

${ }^{230}$ HABERMAS, J., Pensamento Pós-Metafísico, p. 279

${ }^{231}$ Ibidem, p. 95-96.

${ }^{232}$ Id., Soberania Popular como Procedimento: um conceito normativo de espaço público, p. 107.

${ }^{233}$ Ibidem, p. 112-113.
} 
estratégico, típico do sistemas financeiros e econômicos, e o agir comunicativo, típico do mundo da vida em que são necessárias ações coordenadas para formação de uma sociedade. Salta aos olhos a obviedade de que, diante das constantes derrotas do agir comunicativo na arena política, isto é, da supressão do diálogo, há uma diminuição dos processos discursivos e uma corrupção do discurso, enquanto meio comunicacional ${ }^{234}$. É essa diminuição do agir para o entendimento nas democracias exclusivamente representativas que perpetua situações de dominação e estruturas de não reconhecimento e desigualdades sociais. Saber quem domina e quem é dominado é uma questão de observação empírica, mas há, nos espaços públicos, uma disputa entre os processos de formação espontânea de opinião. De um lado, a geração comunicativa do poder legítimo, do outro, a obtenção de legitimação pelo sistema político refletido no poder administrativo ${ }^{235}$.

Quando Habermas trabalha com a ideia de colonização do mundo da vida, ele utiliza justamente essa perspectiva de perda de espaço do agir comunicativo para o agir estratégico. Seria o momento em que os sistemas financeiro e econômico são capazes de introduzir o agir estratégico até no mundo da vida, que seria o lugar primordial do agir comunicativo. No caso da teoria de Habermas, isso significa a diminuição de uma ética intersubjetiva social, diminuindo a possibilidade de ações coordenadas baseadas em acordos racionalmente motivados; reduzindo a autonomia e a autorrealização dos sujeitos, contrariando os princípios comunicativos que deveriam orientar a formação de uma sociedade democrática. $\mathrm{O}$ mundo da vida perde força ${ }^{236}$. Passa-se a encarar tradições e questões éticas comunitárias do ponto de vista mercadológico, há um grande caminho trilhado para que as relações socialmente integradas se transformem em

\footnotetext{
${ }^{234}$ WARREN, M. E., Deliberative Democracy and the Corruption of Speech, p. 18.

${ }^{235}$ HABERMAS, J., Soberania Popular como Procedimento: um conceito normativo de espaço público, p. 108.

236 “O sujeito do agir estratégico age, sempre, sob o pano de fundo do seu mundo da vida e face às instituições ou pessoas que o constituem - mas em ambos os casos de uma forma transfigurada. $\mathrm{O}$ pano de fundo do mundo da vida é neutralizado de um modo singular para a resolução das situações que ficaram sujeitas aos imperativos do agir orientado para o êxito; o mundo da vida perde a sua força coordenadora de acções enquanto recurso garante consensos. E, como todos os outros factos do mundo da vida (que agora já não é partilhado a nível intersubjetivo), também os outros participantes da interacção são apenas encarados como factos sociais - como objetos que o autor (no caso de necessidade com o recurso a efeitos perlocutórios) pode influenciar, ou levar a determinadas reações.” Id., Pensamento Pós-Metafísico, p. 108.
} 
relações contratuais, é a verdadeira burocratização de um mundo da vida que deveria se realizar de forma coordenada intuitiva ${ }^{237}$.

Não é difícil deslocar o problema que a colonização do mundo da vida gera na ética intersubjetiva para os problemas que o agir estratégico geram para a democracia. A democracia, seja qual for a definição utilizada, parte do pressuposto de um ideal de governo do povo para o povo. Como pode ser chamado de democrático um sistema que utiliza o operador da representação para diminuir as capacidades discursivas do espaço político, reduzindo a possibilidade de diálogo e utilizando-se sempre do agir estratégico? As discussões sobre decisões do Estado já não passam mais por uma arena política. A rede sistêmica da economia e da administração subtrai o saber intuitivo coordenado dos membros participantes do mundo da vida. Enquanto isso, as descrições comodificadoras da sociedade imigram dos sistemas econômicos e financeiros para o mundo da vida, os sujeitos se tornam estranhos a si próprios ${ }^{238}$.

Warren aponta o problema da corrupção do discurso como algo prejudicial para a democracia. É interessante destacar o jogo de palavras feito pelo autor para dizer que o discurso de corrupção é uma forma de corrupção do discurso. As alegações de que todos os políticos são mentirosos e hipócritas somente desqualificam a política como ausência de compromisso democrático com o discurso. Cria-se uma verdadeira sina de se abrir mão do discurso para fazer política $^{239}$.

Talvez a sociedade se encontre nesse ponto, um momento de descrença na política, enquanto situação de diálogo capaz de se apresentar de forma discursiva, nas arenas decisórias. Isso vem de um problema que também é endêmico nas grandes democracias existentes: a relação com as arenas decisórias é sempre mediada, seja pelo operador da representação, seja por veículos de informação. Nesse caso, o sujeito precisa buscar credibilidade nas informações que lhe chegam indiretamente ${ }^{240}$. Assim, fica mais difícil identificar o agir estratégico e rejeitar as pretensões de validade que são levantadas no discurso político; suprime-se, junto

\footnotetext{
${ }^{237}$ HABERMAS, J. Pensamento Pós-Metafísico, p. 234.

238 Ibidem, p. 183-184.

${ }^{239}$ WARREN, M. E., Deliberative Democracy and the Corruption of Speech, p. 4

${ }^{240}$ Ibidem, p. 24
} 
com a discursividade da democracia, a oposição, que também é elemento fundamental da democracia ${ }^{241}$.

É fácil concluir que a introdução do agir estratégico, no mundo da vida e no mundo da política, compromete e dificulta o caráter democrático de um sistema. Afinal:

O uso estratégico latente da linguagem é parasitário porque só funciona se pelo menos um dos lados partir do princípio de que a linguagem é utilizada de forma orientada para o entendimento. Quem age de forma estratégica tem de infringir a condição da sinceridade do agir comunicativo de uma maneira imperceptível. ${ }^{242}$

A democracia é incompatível com uma perspectiva parasitária de um agente que deseja que os outros não se posicionem em relação à validade dos discursos em uma sociedade. Ela precisa se resguardar dessa forma parasitária de ação, buscando o fortalecimento de uma comunicação ampla que possibilite ao indivíduo dar respostas e fazer alegações capazes de provocar no locutor uma adequação do discurso ${ }^{243}$. Com isso, enfrentou-se o ponto de que a ação comunicativa é típica do mundo da vida e não se adequa aos sistemas financeiros do dinheiro. É preciso que as arenas decisórias políticas fortaleçam estruturas de diálogo capazes de rejeitar a possibilidade do agir estratégico. A inclusão de mecanismos de participação direta diminuí a mediação existente nos modelos exclusivamente representativos, aumentando a possibilidade dos participantes do discurso de se posicionarem em relação às pretensões de validade dos agentes de estado.

Como comprovação empírica, pode-se citar o aumento da participação feminina nos processos discursivos de decisão, principalmente, nos últimos anos. Ainda que a situação da mulher permaneça complicada e nem de longe seja possível dizer que o machismo foi derrotado. Após a década de 1970, o feminismo no Brasil foi responsável por levar para arena pública questões consideradas secundárias ou privadas, como afetividade, sexualidade, violência, reprodução, poder e dupla jornada de trabalho. Em grande parte, isso ocorreu diante do aumento da participação feminina na institucionalidade decisória dos

${ }^{241}$ DAHL, R. A., Polyarchy: participation and oposition, p. 48-49.

${ }^{242}$ HABERMAS, J., Pensamento Pós-Metafísico, p. 140

${ }^{243}$ WARREN, M. E. Deliberative Democracy and the Corruption of the Speech, p. 8 e 14. 
últimos anos, através da criação da Secretaria da Mulher com status ministerial, do funcionamento dos Conselhos de Mulheres que orientaram políticas públicas e outros fóruns de participação que passaram a ser largamente ocupados por mulheres feministas ${ }^{244}$. Fica claro que a diminuição da mediação entre os problemas femininos e o governo concretizou melhorias democráticas e de reconhecimento.

Agora, há que se falar dos problemas causados pela existência de mais de um mundo da vida dentro de uma sociedade, de como isso afeta a questão democrática e porque os mecanismos de participação direta seriam facilitadores para estabelecer comunicação entre os diferentes mundos da vida.

Apenas retomando o ponto que ficou um pouco distante, os enunciados comunicativos possuem um background formado por definições contextualizadas, que precisam se sobrepor para que seja possível estabelecer a comunicação ${ }^{245}$. Em princípio, não há chance de que atores comunicativos se desloquem dos horizontes de seus mundos da vida, isto é, para acontecer, a comunicação depende de um contexto compartilhado pelos participantes dos processos discursivos ${ }^{246}$.

Seria possível identificar a existência de diferentes mundos da vida, em várias sociedades, mas, é mais fácil compreender a ilustração usando sociedades onde a desigualdade social ainda é gigantesca. Conforme levantado no capítulo anterior, há um largo contexto de desigualdade social no Brasil que afasta e segrega classes e sujeitos, de forma que não existe uma ação coordenada necessária para caracterizar uma sociedade, em todos os contextos de interação social. Ainda se fazem presentes guetos físicos, ideológicos e de experiência que impedem o compartilhamento de espaços e até mesmo um consenso linguístico básico necessário para a comunicação ${ }^{247}$. Na verdade, a marcante desigualdade social e a separação de sujeitos de diferentes classes retiram a intersubjetividade

${ }^{244}$ ROCHA, L. M. L. N., Feminismo, Gênero e Políticas Públicas: desafios para fortalecer a luta pela emancipação, p. 318.

${ }^{245}$ HABERMAS, J., Pensamento Pós-Metafísico, p. 121.

${ }^{246}$ Ibidem, p. 126.

247 Como exemplificado no capítulo anterior, as diferenças de realidade entre morro e asfalto, cidade e campo, litoral e interior acabam por impossibilitar a compreensão do espaço do outro e a própria compreensão de conceitos básicos de forma diferente. Afinal, o que é a vida para um morador da favela que convive quase diariamente com a morte e o que é a vida para o morador de um rico condomínio de um bairro nobre que nunca teve contato direto com a violência? 
do reconhecimento linguístico, uma vez que existem mundos de vida completamente diferentes dentro de uma mesma sociedade. Como estabelecer a comunicação entre os diferentes mundos de vida? Para responder essa questão, é necessário retornar a alguns aspectos da teoria da linguagem de Habermas.

Seja nas ações comunicativas, seja nas ações estratégicas, há ilocuções e perlocuções. O que significa dizer que, mesmo nos processos cooperativos de interpretação necessários ao agir orientado para o entendimento, a relação intersubjetiva interpretativa deve passar por várias fases, antes de atingir uma comunicação. Mesmo diante de uma ação comunicativa, na primeira das fases, os participantes do discurso podem não ter a bagagem suficiente para as ações coordenadas $^{248}$. Da mesma forma que problemas de comunicação podem surgir da confusão entre ações orientadas para o entendimento ou para o sucesso ${ }^{249}$.

Portanto, serão necessários contextos de interação onde o agir comunicativo possa efetivar-se através de interações estratégicas, uma vez que é fundamental que um mundo da vida constituído conecte-se a outro para criar consensos normativos básicos ${ }^{250}$. Ou seja, é preciso que sejam utilizadas formas de ação estratégicas e efeitos perlocutórios capazes de construir as bases para uma efetiva relação de comunicação, sempre lembrando que ainda deve ser resguardada no locutor a intencionalidade do entendimento.

Diante da colonização do mundo da vida pelo agir estratégico e das ações de dominação dos sistemas financeiros e mercado sobre política, é impossível conceber a capacidade da representação indireta de dar conta da criação de contextos interativos capazes de reduzir a lacuna entre os diferentes mundos sociais. Até mesmo, porque a representação indireta encontra-se, em sua maioria, ocupada pelas classes mais altas que parecem não possuir interesse em alterar as situações de desigualdade social e as diferenças discursivas. A arena de decisão exclusivamente representativa, da forma como está posta hoje, impossibilita a

\footnotetext{
${ }^{248}$ HABERMAS, J., The Theory of Communicative Action: Reason and the rationalization of society. V. $1,331$.

${ }^{249}$ Ibidem, p. 332.

250 "Do ponto de vista da teoria da comunicação, porém, as interacções estratégicas podem apenas ocasionar-se no interior do horizonte de mundos da vida já constituídos noutro lugar nomeadamente como alternativas a acções comunicativas que teimam em não surtir efeitos." Id., Pensamento Pós-Metafísico, p. 108.
} 
criação de intersubjetividade entre os diferentes mundos existentes na sociedade. $\mathrm{O}$ fato de haver milhares de mediadores entre representante e representado já se coloca como algo que dificulta o entendimento e a possibilidade de construir consensos linguísticos básicos, privilegiando os que detêm o poder. Por isso os mundos - ou grupos - dominantes continuam utilizando-se apenas da ação estratégica em relação aos outros mundos, sem nenhuma intenção de construir uma relação comunicativa.

Pode-se ainda dizer que as classes dominantes mantêm as classes dominadas sob tal forma de ausência de reconhecimento, em que, por exemplo, o pobre preto no Brasil experimenta tantas situações de humilhação e de outras formas de desrespeito, que há mesmo uma perda da capacidade discursiva ${ }^{251}$. A análise vem de Ana Fascioli dizendo que Honneth, ao criticar uma ética discursiva em favor de uma ética de reconhecimento, acaba por ignorar que também há uma vivência moral no intercâmbio discursivo. Afinal de contas, as experiências de sofrimento e humilhação podem advir da decepção em relação à manipulação e mentira do outro que age apenas orientado para sucessos individuais, sem pretensão de entendimento $^{252}$.

É preciso conceber as formas de encontro nos mecanismos de participação direta como capazes de diminuir o abismo existente entre os diferentes mundos da vida, gerando reconhecimento intersubjetivo linguístico e, porque não, social ${ }^{253}$. A possibilidade de aproximação entre as diferentes classes sociais que atuam de forma diversa e a diminuição das estruturas de dominação existentes só podem ocorrer com a amplificação do diálogo. Veja:

Uma vez que a intersubjectividade da comunicação linguística é de si porosa e porque o consenso alcançado por meios linguísticos não elimina, plenamente as diferenças entre as perspectivas dos locutores, pressupondo-as antes como insuperáveis, o agir orientado para o entendimento também serve como médium de processos formativos que possibilitam ambas as coisas simultaneamente: socialização e individuação. ${ }^{254}$

${ }^{251}$ FASCIOLI, A., O Reconhecimento como Núcleo de Fundamentação da Normatividade: reflexões sobre a crítica de Honneth à ética do discurso habermasiana, p. 52.

${ }^{252}$ Ibidem, p. 49.

${ }^{253}$ Quando falo em reconhecimento social remeto às dimensões do reconhecimento de Honneth e à perspectiva de reconhecimento de Rainer Forst.

${ }^{254}$ HABERMAS, J., Pensamento Pós-Metafísico, p. 72. 
Dessa forma, é necessário defender a manutenção de uma perspectiva discursiva nas democracias atuais, através da utilização de mecanismos de participação direta que amplifiquem o diálogo. Pensar as formas de participação direta do cidadão deve ser pensar sempre em plataformas discursivas que possibilitem a contestação dos enunciados apresentados e a orientação para o entendimento. Os locais de encontro suprimem os mediadores que facilitam a utilização de um agir estratégico e perpetuam situações de dominação.

Diante do atual cenário de crise política, é notória a incapacidade do modelo representativo de garantir comunicação entre representante e representado, o que foi analisado em relação ao Brasil, no capítulo anterior. A colonização do mundo da vida, através do avanço das ações estratégicas, ocorre principalmente nas arenas decisórias políticas. Não pretendo fazer uma divisão absoluta habermasiana entre esfera pública e privada, já que reconheço os problemas e dessubjetivações que esse caminho pode suscitar. Mas a principal batalha entre agir estratégico e agir comunicativo deve ocorrer nos fóruns governamentais de decisão, uma vez que é ali que se definem situações normativas que deveriam ser justificáveis para todos os cidadãos. $\mathrm{E}$ a batalha parece mais fácil de ser vencida sem a utilização dos mediadores típicos dos sistemas exclusivamente representativos.

Os mecanismos de participação direta além de possibilitarem espaços que facilitam a conversa, por serem tipicamente discursivos, também possibilitam a aproximação entre dois mundos da vida diferentes. Os atuais modelos democráticos exclusivamente representativos e suas histórias mostram que a representação não foi capaz de aproximar dois mundos diferentes, em situações de grande desigualdade social. Já as experiências de participação direta no Brasil, com todos os problemas destacados anteriormente, mostram como foi possível reduzir a pobreza e gerar reconhecimento intersubjetivo, ainda que em graus bem inferiores aos desejados ${ }^{255}$.

Dessa forma, é possível proteger a democracia contra a corrupção do discurso, construindo mecanismos e instituições que incentivem e ensinem cidadãos a se aproximarem através de ações comunicativas, tanto entre si e do governo. É indispensável poder confiar democraticamente em compromissos

${ }^{255} \mathrm{O}$ ponto foi largamente explorado no capítulo anterior. 
baseados em uma intersubjetividade discursiva e em um comprometimento que tenha por base as expectativas normativas da linguagem. Os representantes não podem resguardar-se do contato com os representados por 4 (quatro) ou mais anos, porque sua intenção e a intenção de seu local de fala precisam ser identificados e contestados ${ }^{256}$ também, e principalmente, ao longo do mandato. Não parece que haja outro caminho para uma construção política de ação comunicativa que a utilização de formas de participação direta em democracias de larga escala.

\section{2.}

\section{Participação Direta e o Direito de Justificação}

É importante esclarecer o porquê da escolha de trabalhar com o princípio da justificação de Forst e não com os princípios (U) e (D) de Habermas. Afinal, o que torna mais interessante dar continuidade na análise utilizando as ideias de Forst e não as de Habermas já que ele avança em seu pensamento tratando das mesmas questões? A opção feita nesta pesquisa não significa dizer que o princípio democrático discursivo de Habermas esteja errado ou discordar do que o autor apresenta. Mas a teoria da justificação desenvolvida por Forst parece ser um pouco mais sofisticada para analisar as situações políticas existentes na sociedade atual.

Apesar de discordar parcialmente das afirmações de que Habermas não incorporou em sua teoria as questões de relações de $\operatorname{poder}^{257}$ - ou aqui dominação -, concordo que ele oferece bases limitadas para o tratamento dessas questões de forma pragmática. Por Forst incorporar um pensamento crítico em relação ao próprio poder, torna-se capaz de trabalhar seu princípio normativo de melhor forma.

${ }^{256}$ WARREN, M. E., Deliberative Democracy and the Corruption of Speech, p. 21 e 23.

${ }^{257}$ Divergindo da maioria, entendo que os fatores de poder em Habermas - ainda que de forma sutil - estão no reconhecimento de que o agir estratégico pode ser carregado de forma a impedir que os outros tenham uma posição de validade em relação à proposição ou enunciado do locutor. O que ocorre quando uma das partes tem conhecimento completo da instrumentalização dos atos de fala capazes de manipular e gerir o outro e, por essa razão, impede o posicionamento do interlocutor no espaço de trocas de razão. Claramente, há indicação de uma relação assimétrica onde um dos sujeitos suprime a capacidade discursiva do outro; o que parece se encaixar nas noções de poder trabalhadas pela teoria crítica. 
Rainer Forst constrói sua teoria de justiça com base no princípio da justificação, que se revela no direito de todo cidadão em entender como justificável a ordem à qual se submete, bem como na obrigação de todo o cidadão, numa relação de poder, de estabelecer estruturas de justificação capazes de garantir esse direito aos sujeitos da comunidade política ${ }^{258}$. Para essa reconstrução, Forst trabalha com múltiplos conceitos opostos que fazem parte do arcabouço teórico desta pesquisa; as oposições entre tolerância como permissão e tolerância como respeito; ou entre poder, dominação e violência; assim como os conceitos de dignidade humana, reconhecimento e justiça social são essenciais para compreender a ideia de uma normatividade baseada na justificação. Por essa razão, é preciso encarar com mais detalhes esses conceitos.

O princípio da justificação é para Forst um princípio moral de orientação que está diretamente ligado à dignidade humana. Toma-se como ponto de partida a ideia de que um ser humano digno só existe quando possui um direito à justificação da ordem à qual está submetido junto com outros sujeitos. Há, dentro dessa noção de justificação, a obrigação moral mútua, recíproca e geral de estabelecer ordens de justificação. Essa dignidade é uma qualidade, um status, que se aplica aos seres humanos, simplesmente por os serem; isto é, independente de suas identidades e características subjetivas. Para isso, é necessário que o sujeito tenha a possibilidade de evitar pobreza, humilhação, entre outras formas de não reconhecimento de sua característica como ser humano ${ }^{259}$.

Portanto, há violação da dignidade humana, por exemplo, quando o ser humano é colocado, obrigado ou coagido a viver em pobreza. Essa ação e imobilização do sujeito vêm sempre de outros seres humanos que agem com esta finalidade ou, podendo, não evitam a situação. É preciso pensar nesse ponto de forma relacional, observando os processos de interação e as estruturas sociais que perpetuam esses cenários de desrespeito à dignidade humana. Apesar de falar em pobreza, o ponto central da violação da dignidade humana é ser ignorado, não se trata da ausência dos meios necessários para viver conforme o padrão de uma vida

258 "De acordo com esse princípio, em um contexto de justiça, cada membro possui um direito básico à justificação, que consiste num direito à razões adequadas para as normas de justiça que devem ser aplicadas em geral” Tradução Livre. FORST, R., The Right to Justification: elements of a constructivist theory of justice, p. 194.

${ }^{259}$ Id., Justification and Critique: Towards a Critical Theory of Politics, p. 96-98. 
boa, mas de uma desconsideração consciente do status moral do sujeito enquanto ser humano com direito à justificação. O sujeito torna-se invisível para fins de legitimação das relações sociais ${ }^{260}$. Na sociedade pós-metafísica, tratar os outros conforme pessoas dignas de humanidade exige um exercício de respeito às éticas divergentes das suas próprias. É preciso compreender que as comunidades complexas podem ser vistas como um modelo abstrato de união de muitos, talvez um aglomerado de sujeitos individuais, que, apesar de sua forte característica comunitária, não podem ter suas éticas individuais violadas ${ }^{261}$. Por esse motivo, Forst vai articular a noção de tolerância como respeito.

A ideia de tolerância do autor é fundamento para trabalhar com a possibilidade de compartilhamento de um mundo comum em determinada sociedade. Isto porque, também na linha de Habermas, após a quebra do monopólio das éticas intrassubjetiva e justificações metafísicas, o mundo se torna um lugar de estranhos. Nesse sentido, os conceitos normativos que pretendem explicar a sociedade devem lidar com a realidade de que há profundas divergências éticas entre seus participantes. Isso confere extrema importância ao conceito de tolerância, uma vez que, ao ser incapaz de concordar e aceitar determinado paradigma ético material do outro, o eu apenas pode tolerar sua existência; talvez a religião seja o maior exemplo desta afirmação. Nas sociedades pós-metafísicas, não tolerar significa não reconhecer intersubjetivamente, o desprezo ou a negação à individualidade ética do outro é uma forma de desrespeito no sentido de reconhecimento de Honneth ${ }^{262}$. Apesar disso e da forte marca liberal kantiana em Forst, a distinção entre tolerância como permissão e tolerância como respeito insere um conteúdo normativo moral no conceito que o torna menos vulnerável às críticas que a noção de tolerância recebe, enquanto excludente e hierarquizadora ${ }^{263}$. Mas não há dúvida de que a tolerância é um

\footnotetext{
${ }^{260}$ FORST, R., Justification and Critique: Towards a Critical Theory of Politics, p. 98.

${ }^{261}$ HONNETH, A., The Struggle for Recognition: The Moral Grammar of Social Conflicts, p.12.

262 Ibidem, p. 158.

${ }^{263}$ A maioria das críticas em relação ao conceito de tolerância deve ser levada em consideração para que ele não seja utilizado para excluir e/ou hierarquizar determinados comportamentos ou escolhas éticas na sociedade. Nesse sentido, é muito pertinente o trabalho de Wendy Brown em combate à utilização da tolerância, enquanto princípio orientador da teoria política e social. Para maiores informações ler BROWN, W., Tolerance as a Discourse of Depoliticization. Porém, para os efeitos dessa pesquisa, entendo que a noção de Forst em relação à tolerância como respeito é suficiente para combater as perspectivas hierarquizadoras que o princípio da tolerância pode assumir.
} 
conceito normativamente dependente, já que está diretamente relacionada à noção de $\operatorname{poder}^{264}$. Por essa razão, ao defendê-lo como um princípio normativo, é necessário tomar os cuidados e cautelas com os problemas levantados pelos críticos do conceito de tolerância.

São três componentes fundamentais do conceito de tolerância: (i) objeção, (ii) aceitação e (iii) rejeição. Para ser tolerado, deve haver alguma razão para que o comportamento seja objetável, a priori, porém, superando-se a objeção inicial, ainda que exista alguma divergência ética, a tolerância se dá quando há aceitação. Ao mesmo tempo, os limites da tolerância devem ser desenhados para marcar a linha em que é preciso rejeitar a ação objetável, isto é, quando as razões para aceitação desaparecem $^{265}$.

Ser tolerante é aceitar a pessoa de acordo com uma norma moral geral aplicável a todos os seres humanos, independente de suas éticas particulares, passa por uma separação entre crença ética particular e normatividade social ${ }^{266}$. A definição do intolerante pressupõe a incapacidade de separar suas crenças éticas da normatividade social. Porém, há sempre a preocupação com o paradoxo da (in)tolerância, uma vez que definir o intolerante será, normalmente, resultado de parcialidade e intolerância ${ }^{267}$. Por sua vez, os limites da tolerância se impõem, quando determinado grupo tenta fazer de suas visões éticas uma imposição, o que ocorre através da dominação de determinado grupo sem que haja comprometimento com a troca de razões. É uma negativa do direito à justificação que se revela na forma de intolerância e, por essa razão, não deve ser tolerado ${ }^{268}$. A tolerância pode ocorrer de duas formas, baseada em respeito e reconhecimento mútuo ou como expressão de desrespeito e dominação ${ }^{269}$.

Nesta esteira, Forst trabalha a diferenciação entre a tolerância enquanto permissão e tolerância enquanto respeito. A primeira é a autorização ou permissão para que determinados grupos sub-representados vivam de acordo com seus valores éticos, desde que esses grupos aceitem a autoridade do grupo dominante.

\footnotetext{
${ }^{264}$ FORST, R., Os limites da tolerância, p 18.

${ }^{265}$ Id., Justification and Critique: Towards a Critical Theory of Politics, p. 127.

${ }^{266}$ Ibidem, p. 142

${ }^{267}$ Id., Os limites da tolerância, p. 17.

268 Ibidem, p. 23.

${ }^{269}$ Id., Justification and Critique: Towards a Critical Theory of Politics, p. 127.
} 
É uma relação hierárquica, em que há caracterização da autoridade que restringe a identidade do grupo dominado ao espaço privado ${ }^{270}$. Aqui parece estar a noção de tolerância tão criticada pelos teóricos contrários à utilização do conceito na teoria social e política.

Quando a tolerância se estabelece de forma hierárquica, é necessário que haja uma forma de autoridade presente, o que significa que determinado grupo preserva certo status de superioridade. Há uma necessidade de que o grupo dominado, a que se permite que continue vivendo de acordo com suas crenças, não reivindique status público e político de iguais. Esse tipo de tolerância só acontece porque, dentro das alternativas possíveis, ela é a menos custosa para o grupo dominante que a define. Há clara discrepância entre as duas partes da relação, o grupo dominante tolera, enquanto o outro aceita, não há reciprocidade $^{271}$. A tolerância como permissão é contraditória ao ser, ao mesmo tempo, libertadora e repressiva, além de poder sempre ser revogada. Ela é libertadora no sentido de que, dependendo da situação anterior, a concessão, ou permissão levará o grupo dominado a uma situação melhor do que a que experimentava. Mas é repressora, já que permitir e autorizar significa aceitar a posição menor e desprivilegiada do outro; gerando problemas identitários, uma vez que as "políticas de tolerância" estigmatizam e fazem com que subjetividades “estranhas" sejam incluídas e excluídas no mesmo movimento ${ }^{272}$.

A tolerância como respeito aparece no momento em que há um reconhecimento intersubjetivo entre os diferentes grupos éticos de uma comunidade, sejam eles maioria ou minoria. A aceitação da crença e dos valores éticos do outro é respeitada, ainda que existam diferenças notáveis de crenças e costumes. O outro é visto como sujeito de valores, não apenas lhe é permitido exercer alguma crença individual, que não se reconhece como importante, ao contrário, identifica-se nele um conjunto de valores éticos pessoais que, mesmo diferentes dos de outros membros da sociedade, devem ser respeitados; nessa relação, está presente um forte componente da estima intersubjetiva ${ }^{273}$. Há um

${ }^{270}$ FORST, R., Os limites da tolerância, p. 20.

${ }^{271}$ Id., Os limites da tolerância, p. 20.

${ }^{272}$ Id., Justification and Critique: Towards a Critical Theory of Politics, p. 131.

${ }^{273}$ HONNETH, A., The Struggle for Recognition: The Moral Grammar of Social Conflicts, P. 129. 
respeito baseado no critério de reciprocidade, em que não poderá haver privilégio de determinada comunidade ética em detrimento da outra. As partes reconhecem uma a outra com um sentimento recíproco, há necessidade de intersubjetividade para conceber a tolerância como respeito ${ }^{274}$. Ainda que haja aspectos e visões incompatíveis, os sujeito possuem um respeito mútuo que enxerga o outro como politicamente igual com um direito à justificação ${ }^{275}$.

Diferente da noção de tolerância como permissão, na modalidade do respeito, não existe uma separação necessária e definida entre pessoa privada ética e "citoyen político" livre de qualquer subjetivação individual. Na verdade, é necessário que todos os sujeitos sejam capazes de figurar em qualquer espaço sem separação entre público e privado - com as qualidades éticas que lhe são inerentes, seus desejos e questões culturais ${ }^{276}$. No respeito mútuo e numa relação intersubjetiva, há uma lógica emancipatória em detrimento de uma lógica de dominação ${ }^{277}$. As comunidades éticas minoritárias podem, através de participação como sujeitos com direito à justificação e direitos políticos iguais, buscar um aumento do reconhecimento intersubjetivo de suas culturas, o que poderia se ver como uma forma de luta por reconhecimento, através da troca de razões dentro dos espaços de justificação.

Não há como falar em ordem de justificação e princípio de justificação, se não é possível conviver com o diferente. Por essa razão, a noção de tolerância como respeito é basilar da construção normativa de Forst. Desde já, segue-se a pista de que as sociedades com situações de tolerância como permissão em relação a grupos minoritários ou sub-representados não possuem estruturas básicas de justificação. Nesse sentido, as situações de tolerância como permissão são típicas de espaços não democráticos, já que há clara supressão dos espaços de trocas de razão emancipatórios típicos das relações de tolerância como respeito.

Já alicerçado em uma ideia de tolerância como respeito, o princípio da justificação pressupõe que a própria sociedade deve ser entendida como ordens de

\footnotetext{
274 Ao expor isso, Forst deixa aparecer que há um componente de reconhecimento intersubjetivo em sua construção de um princípio da justificação.

${ }^{275}$ FORST, R., Os limites da tolerância, p. 20-21.

276 Ibidem, p. 24.

${ }^{277}$ Id., Justification and Critique: Towards a Critical Theory of Politics, p. 135.
} 
justificação das mais variadas formas ${ }^{278}$. É preciso que todas as relações normativas da sociedade sejam estruturas justas ou justificáveis, das mais sistêmicas estruturadas no mercado e na política às mais simples como a relação entre vizinhos. Trata-se de um procedimento dinâmico e social que deve superar estruturas convencionais e excludentes de discurso numa prática de justificação ${ }^{279}$.

“De acordo com esse princípio [justificação], cada membro participante de um contexto de justiça tem um direito básico à justificação, isto é, um direito de obter razões adequadas para as normas de justiça que devem estar em vigor de forma geral" ${ }^{280}$. Trata-se daquele direito básico ao qual todo ser humano tem direito, pelo simples fato de existir, sem que as suas características particulares sejam levadas em consideração.

A relação de justificação, assim como as relações orientadas para o entendimento, tem uma forte característica crítica. Os participantes devem ser capazes de questionar as condições de justificação - ou de validade - das normatividades existentes. Sendo os sentidos críticos da instersubjetividade justificativa os seguintes: (i) a análise crítica das relações não justificáveis, como exclusão e desigualdade; (ii) a crítica de falsas justificações baseadas exclusivamente em paradigmas metafísicos; (iii) a crítica à ausência de estruturas e instituições que facilitariam a efetivação das primeiras categorias. Ou seja, o princípio da justificação é dependente de uma estrutura básica de justificação que possibilite o questionamento das relações normativas injustificáveis. O ponto crucial é a possibilidade reflexiva de expor e corrigir a má distribuição de recursos necessários para garantir o poder de justificação, incluindo-se os espaços institucionais e informais de troca de razão, que não deixam de ser espaços políticos $^{281}$.

A noção de reflexividade aparece no mesmo sentido das elaborações na teoria da democracia pragmática. Trata-se da possibilidade de adaptação e correção das estruturas, de acordo com as alterações das características de

\footnotetext{
${ }^{278}$ RAINER, F., Justification and Critique: Towards a Critical Theory of Politics, p. 105.

279 Ibidem, p. 124.

${ }^{280}$ Tradução livre. No original, em inglês: "According to this principle, each member within a context of justice has a basic right of justification, that is, a right to adequate reasons for the norms of justice that are to be generally in force". Id., The Right to Justification: elements of a constructivist theory of justice, p. 194.

${ }^{281}$ Id., Justification and Critique: Towards a Critical Theory of Politics, p. 107.
} 
determinada sociedade e suas aspirações aos espaços de troca de razão ${ }^{282}$. Não significa abandonar a estrutura normativa moral do princípio da justificação, como pretenderia a democracia pragmática, mas significa dizer que as estruturas de justificações devem ser historicamente situadas, produtos da complexidade ética e pluralística de uma determinada sociedade ${ }^{283}$.

Ainda que se possa considerar uma noção de justificação situada historicamente e reflexiva, é preciso conservar a ideia de que o princípio da justificação de Forst possui um conteúdo normativo moral. Ele trabalha com dois critérios de avaliação das normas enquanto justificáveis, sendo necessário que as relações de poder, típicas de trocas de razão, se estabeleçam sob esses dois critérios para serem justificáveis e não descambarem para dominação - a generalidade e reciprocidade. $\mathrm{O}$ critério da generalidade revela que as razões de legitimação da norma devem ser aceitas - ou aceitáveis - de forma geral por todos e não apenas pelos grupos dominantes. Quando Forst fala em reciprocidade, trata de que nenhum sujeito, ao justificar ou reivindicar determinada norma, poderia levantar razões que não aplicaria a si mesmo ${ }^{284}$. Esses dois critérios são exatamente os mesmos que o autor utiliza para estabelecer os limites da tolerância e a existência de uma tolerância como respeito. Para não haver dúvida das noções de generalidade e reciprocidade nas palavras do autor:

[reciprocidade] significa que não se reivindiquem certos direitos e recursos que são negados aos outros, e que nossas próprias razões (valores, interesses, necessidades) não sejam projetadas sobre as dos outros ao defendermos nossas pretensões.

[...]

[generalidade] as razões para as normas básicas devem ser reciprocamente aceitáveis e compartilháveis entre todos os cidadãos, não apenas entre grupos dominantes. $^{285}$

Os critérios de generalidade e reciprocidade se aplicam a todas as partes da relação de poder típica dos espaços $\operatorname{comunitários}^{286}$. Isso significa que não é

282 POGREBISCHI, T., Democracia Pragmática: Pressupostos de uma Teoria Normativa Empiricamente Orientada, p. 663.

${ }^{283}$ Em texto dialógico com Rainer Forst, Amy Allen formula exatamente esse ponto com relação ao princípio da justificação. Amy entende que, ainda que se fale em paradigmas de justificação, estes serão sempre sociológicos e historicamente situados. ALLEN, A.; FORST, R.; HAUGAARD, M., Power and Reason, Justice and Domination: a conversation. Journal of Political Power, p. 16.

${ }^{284}$ FORST, R. Os limites da tolerância, p. 22.

285 Ibidem, p. 22. 
apenas ao justificar que o locutor necessita se ater aos dois critérios formulados, mas ao contestar determinada norma moral ou modo de ação, ele não poderá fazer alegações que negaria para si ou para outros. As objeções também precisam ser capazes de ser aceitas ou aceitáveis por todos os outros ${ }^{287}$.

A tão mencionada estrutura básica de justificação de Forst depende desse mínimo que se revela através dos critérios de reciprocidade e generalidade ${ }^{288}$. São critérios decisivos de validade que se transformam num princípio de justificação discursiva. É impossível pensar em relações de poder e justificação que não sejam discursivas no sentido de espaços de troca de razões ${ }^{289}$.

Saindo do terreno exclusivamente filosófico e adentrando um pouco mais na ordem social e política, o princípio da justificação compreende a ordem política, enquanto o local de sua realização de justiça, é a praça onde as ordens injustas injustificáveis - poderiam ser criticadas e questionadas ${ }^{290}$. Para Forst, a construção da ética de justificação não é meramente um princípio moral normativo, ela tem um conteúdo normativo de justiça social que deve se revelar na sociedade política democrática, através de estruturas básicas ou desenvolvidas de justificação. A própria capacidade discursiva de prover e demandar justificações deve ser compreendida em uma virada política ${ }^{291}$ em relação à noção filosófica de justiça ${ }^{292}$.

Mesmo em sua teoria, Forst não nega que a noção de autolegislação é central, porém, deve ser encarada de forma discursiva e intersubjetiva:

Justiça Social não pode servir apenas para a realização do estado constitucional e para a formação da vontade democrática; antes, ela demanda que as relações

${ }^{286}$ É interessante fazer distinção desses critérios com o argumento de Habermas que afirma o caráter universal comunitário, em que todos seriam capazes de assumir a visão do outro dentro das comunidades regidas por parâmetros universais; sendo essa uma noção de reciprocidade habermasiana. HABERMAS, J., Pensamento Pós-Metafísico, p. 223. Porém, conforme apresentado no texto, não é essa a ideia de Forst, em que a noção de reciprocidade pressupõe que o eu não pode reivindicar ou fazer alegações que não aplicaria ao outro da mesma forma que a si. Não há possibilidade de assumir a visão do outro por incompatibilidade ética absoluta.

${ }^{287}$ FORST, R., Justification and Critique: Towards a Critical Theory of Politics, p. 101-102.

${ }^{288}$ Id., The Right to Justification: elements of a constructivist theory of justice, p. 197.

${ }^{289}$ Id. Justification and Critique: Towards a Critical Theory of Politics, p. 101.

290 Ibidem, p. 122.

${ }^{291}$ Tentei utilizar o mesmo termo do autor, que no original em inglês utiliza a expressão "political turn".

292 Seria necessário que a própria teoria crítica se virasse para uma teoria crítica da justiça "enquanto crítica das relações de justificação. Tudo em Id. The Right to Justification: elements of a constructivist theory of justice, p. 196 
sociais relevantes para a justiça sejam geral e reciprocamente justificáveis. E isso requer o estabelecimento das estruturas de justificação correspondentes, não apenas pela viabilidade da democracia, mas para o bem de todos os objetivos que são significantes dentro das relações sociais e institucionais em questão. ${ }^{293}$

Ao entrar em conflito com outras perspectivas de justiça, Forst diz que justiça social, essencialmente, é um conceito contestável e que sua definição absoluta contrastaria com várias visões políticas do mundo. No próprio conceito de justiça, deve haver a possibilidade de conflito e cooperação política e social, uma demanda por uma ordem justificável que compreende uma dívida recíproca entre os membros da comunidade. Uma dívida que se revela na obrigação e no direito do estabelecimento das estruturas básicas de justificação ${ }^{294}$.

Mas mesmo que seja um conceito contestável, o cerne de uma ordem justa tem a tarefa precípua de garantir que não haja nenhuma forma de governança arbitrária ou de dominação nas estruturas normativas e nas instituições da sociedade $^{295}$. Porque a arbitrariedade e a dominação são, ex ante, normativa $\mathrm{e}$ moralmente injustificáveis, já que pressupõem uma tolerância apenas como permissão e a ausência de estruturas de justificação com base nos critérios de generalidade e reciprocidade.

Nessa virada política, há dois conceitos que divergem, em sua determinação, da maioria dos textos da teoria crítica, motivo pelo qual é necessário trabalhar seus conteúdos, mais cuidadosamente, antes de adentrar na parte mais prática da aplicação do princípio da justificação. Não significa dizer que as noções de poder e dominação não existam dentro da teoria crítica; ou que Forst apresenta uma nova concepção dos conceitos. Ele apenas procura interpretar a teoria foucaultiana em conjunto com a perspectiva marxista de dominação, ao mesmo tempo, adequando as noções de poder e dominação à sua construção em torno do princípio da justificação.

Para trabalhar com a noção de poder, Rainer Forst estabelece três diferenciações: o poder, enquanto um conceito nominal, que pode transformar-se em uma espécie de dominação ou ser apenas uma relação de poder; e violência, quando acabam as possibilidades de trocas de razão, ainda que de força coercitiva

\footnotetext{
${ }^{293}$ Tradução Livre. FORST, R., The Right to Justification: elements of a constructivist theory of justice, p. 195.

${ }^{294}$ Id., The Right to Justification: elements of a constructivist theory of justice, p. 188.

${ }^{295}$ Ibidem, p. 189.
} 
ou manipuladora, e o indivíduo utiliza meios não discursivos para implementar sua vontade. Apesar de Forst compreender que dominação é uma espécie do poder, da mesma forma que ele faz em seus textos, farei aqui, serão três conceitos diferentes: poder, dominação e violência.

O desenvolvimento em relação as noções de poder, dominação e violência não pode se esquecer de um ponto fundamental para a teoria da justificação, quando fala em relações e ordens de poder, Forst está falando de relações e ordens de justificação ${ }^{296}$. O poder na sua forma geral, que contempla também a espécie de dominação, tem forma essencialmente discursiva, ele se baseia na possibilidade de ocupar o espaço de razões ou dominá-lo para influenciar os outros ${ }^{297}$.

A preocupação de Forst em relação a noção de poder é conferir-lhe um caráter neutro, ele não poderia englobar apenas um conceito negativo ou positivo; precisa ser os dois, constrangedor e libertador ${ }^{298}$. Existe uma inquietude clara de Forst em relação às noções de poder que lhe inferem uma característica normativa moral, principalmente em relação às definições negativas de poder que acabam por restringir a noção à espécie que é a dominação. O conceito de poder precisa ser não normativo e neutro, porque ele pode ter, diante da análise do cenário, uma função positiva ou negativa, o poder pode ser, em determinado contexto e definição, empoderador e constituinte de libertação ${ }^{299}$. A abordagem pode determinar a positividade ou a negatividade do poder, por isso, tem que ser neutra. Não pode haver uma definição de poder que o determine como bom ou mal por natureza, na verdade, ele é um exercício de um agente sobre outro, sempre guiado pela razão ${ }^{300}$. De forma provocadora, é possível dizer que o poder só é exercido sobre homens livres e apenas enquanto eles estejam livres ${ }^{301}$.

Ao se atribuir uma carga negativa ao poder, quando se diz que ele age contra o interesse de alguém ou quando há imposição de uma vontade em determinado conflito em detrimento de uma das partes, fala-se em dominação que

\footnotetext{
${ }^{296}$ FORST, R., Noumenal Power, p. 9.

${ }^{297}$ Id., Justification and Critique: Towards a Critical Theory of Politics, p. 103.

${ }^{298}$ Id., Noumenal Power, p. 6.

${ }^{299}$ Ibidem, p. 18.

${ }^{300}$ Conforme Rainer Forst em ALLEN, A.; FORST, R.; HAUGAARD, M., Power and Reason, Justice and Domination: a conversation, p. 12.

${ }^{301}$ FOUCAULT, M., The Subject and Power, p. 342.
} 
é apenas uma espécie de poder ${ }^{302}$. Na verdade, poder, nada mais seria do que a capacidade de motivar o outro a pensar ou agir de forma de que, sem a interferência, não o faria. Pode haver mais diferentes meios de exercitá-los, desde que haja sempre o componente de reconhecimento e aceitação ${ }^{303}$. Ou seja, a ideia de poder está na capacidade de um agente em motivar e instigar a outro agente aqui, é importante registrar que o interlocutor não pode perder a característica de agência - pensar ou fazer algo que não teria feito se não fosse pela interferência do primeiro locutor. Não há uma qualificação de bom ou ruim ${ }^{304}$.

Ainda que haja uma ameaça na relação que se estabelece, se os participantes permanecem com suas capacidades de levantar razões mutuamente, não há que se falar em outra coisa, é uma relação de poder. A definição de poder está intrinsecamente ligada à possibilidade de ação de todos os participantes ${ }^{305}$. O poder está sempre situado no espaço de troca de razões, dizer que há uma relação de poder é dizer que esse espaço existe, não é descrever uma situação empírica relacionada ao conteúdo moral que o poder pode assumir na prática ${ }^{306}$

Por essa razão, não há dúvida de que os sujeitos presentes em uma relação de poder devem ser capazes de levantar críticas e questões de justificação e precisam ter reconhecida a possibilidade de rejeitá-las ou qualificá-las como ruim $^{307}$. Há sempre que se avaliar o poder com uma visão de compliance, para saber se a relação se estabelece com base no reconhecimento intersubjetivo necessário para estabelecer um espaço de troca de razões e aceitação ou se há apenas coerção e violência ${ }^{308}$. A partir dessa noção de compliance, fica mais fácil identificar os espaços onde o poder pode descambar para a dominação deixando de ocupar o espaço de troca de razões.

Em casos de relações sociais assimétricas e injustificáveis que se estabelecem no fechamento dos espaços de justificações, como algumas relações que aparentam ser legítimas, naturais, provenientes de Deus ou de certa maneira inalteráveis sem

\footnotetext{
${ }^{302}$ FORST, R., Noumenal Power, p. 4-5.

${ }^{303}$ Conforme Rainer Forst em ALLEN, A.; FORST, R.; HAUGAARD, M., Power and Reason, Justice and Domination: a conversation, p. 12.

${ }^{304}$ FORST, R., Noumenal Power, p. 6-7.

${ }^{305}$ Ibidem, p. 7.

${ }^{306}$ Ibidem, p. 3.

${ }^{307}$ Idem.

${ }^{308}$ Conforme Mark Haugarrd em ALLEN, A; FORST, R; HAUGAARD, M., Power and Reason, Justice and Domination: a conversation, p. 13.
} 
deixar espaço para qualquer alternativa para os sujeitos que as experimentam, estamos diante de formas de dominação ${ }^{309}$.

Nos espaços de dominação, há uma conjuntura de justificações unilaterais hegemônicas que não possuem características de reciprocidade e generalidade. As justificações são aceitas como naturais, legítimas e seguras, mesmo que o participante não esteja diante de graves ameaças. Aqui se encerra o espaço de troca de razão, a atuação discursiva do agente de dominação não vê no outro um sujeito de poder, não pretende vinculá-lo, através de um agir discursivo de troca de razões, sendo o outro um mero objeto do seu agir ${ }^{310}$.

A noção que separa o poder da espécie de dominação tem alta relação com a teoria do agir comunicativo de Habermas. Nas relações de dominação, suprimemse as características intersubjetivas discursivas e a orientação pelo entendimento típica dos espaços de troca de razão para estabelecer uma ação que apenas sobrepõe um agente ao outro, há uma assimetria típica dos locais do agir estratégico. Não é difícil dizer que as relações de poder são orientadas por um agir comunicativo, enquanto as relações de dominação tratam de um agir estratégico $^{311}$.

$\mathrm{Na}$ constitutiva tensão plural que provoca contradições inerentes a uma sociedade pós-metafísica, deve ser evitados que os espaços da sociedade descambem para relações de dominação. Essa transição pode ocorrer, quando as ordens de justificação se consolidam em sistemas hierárquicos e se transformam em espaços sem troca de razão típicos de estruturas de dominação; podendo ainda piorar e se transformar em violência, quando não há só o fechamento do espaço de troca de razões e o não reconhecimento do sujeito, enquanto sujeito político, mas há utilização de outros meios não os discursivos para impedir a ação do sujeito ${ }^{312}$.

\footnotetext{
309 Tradução livre. FORST, R., Noumenal Power, p. 20-21.

${ }^{310}$ FORST, R., Noumenal Power, p. 21.

311 Acredito que tenha ficado clara a noção que estabeleci entre as noções de poder e dominação com agir comunicativo e estratégico, principalmente, após as longas explicações no item anterior. Porém, não ignoro que o agir comunicativo de Habermas não parece, à primeira vista, englobar as noções de manipulação e influência que Forst insere em sua noção de poder. Entretanto, o caráter comunicativo na noção de Forst é tão forte, ao inserir a necessidade de uma intersubjetividade discursiva e de um espaço de livre troca de razões, que vejo apenas um desenvolvimento, mais próximo da realidade, da teria comunicativa de Habermas que não perde sua importância por aprofundar os aspectos da virada linguística.

${ }^{312}$ FORST, R., Justification and Critique: Towards a Critical Theory of Politics, p. 103.
} 
Mark Haugaard, em diálogo com Rainer Forst e Amy Allen, faz uma colocação interessante ao registrar que certas estruturas subalternas podem se esforçar para manter a dominação, de forma que não seria correto dizer que apenas o uso puro da razão possibilita a dominação. Ao mesmo tempo, ele reconhece que as formas de dominação são mais eficazes quando se estabelecem como parasitas sobre os meios genuínos de ação comunicativa ${ }^{313}$. Ora, mais uma vez, as críticas levantadas são dignas de oferecer a cautela necessária para tratar do assunto. Realmente, não é possível pensar em dominação, quando se fala em meios discursivos stricto sensu, mas, quando se incorpora, na teoria normativa da justificação, todos os espaços de encontro político, ou seja, todos os espaços sociais de relações entre agentes que devem ser considerados espaços de troca de razão, fica complicado identificar algum momento em que a dominação poderia se estabelecer de forma não discursiva, principalmente, quando se considera uma outra forma de ação que é a violência, como uma forma diferente do poder. Até porque, racionalizar seria dar razões apropriadas resultantes do princípio da justificação que - não faz mal repetir - depende da orientação de critérios de tolerância como respeito, generalidade e reciprocidade ${ }^{314}$.

No diálogo supracitado, Amy Allen insiste no ponto de Mark dizendo que não é possível acreditar que a dominação se dê somente de forma discursiva, já que isso seria incompatível com a crença de que a troca de razões é uma ferramenta para desmascarar as relações de dominação e empoderar sujeitos dentro de certas situações sociais e históricas. Entende também que o poder não opera sempre através da razão, mas, em certos momentos, atropela o consentimento dos atores subalternos, atuando diretamente sobre o corpo com afetação nas internalizações de desejos afetivos e inconscientes. Logo, para desmascarar as situações de dominação e subordinação que atuam sobre o corpo, seria necessário mais do que o poder da razão ${ }^{315}$.

Mais uma vez, não acredito que os pontos levantados por Mark e Amy estejam errados, é necessário destacar o papel dos corpos, desejos e afetos enquanto mecanismos de dominação. Mas no que toca o aspecto discursivo do

${ }^{313}$ ALLEN, A.; FORST, R.; HAUGAARD, M., Power and Reason, Justice and Domination: a conversation, p. 8-9.

${ }^{314}$ Conforme Rainer em Ibidem, p. 11.

${ }^{315}$ Amy Allen em Ibidem, p. 10 e 16-19. 
jogo político democrático, é preciso reconhecer que o corpo e os próprios afetos sejam instrumentos de argumentação dentro do espaço de troca de razões, o corpo não pode perder seu poder de influenciar outros agentes. Indo nesse sentido, Forst compreende que o corpo não pode ser visto como uma realidade além da justificação, na verdade trata-se de um arcabouço de justificações sociais capazes de possibilitar que a pessoa se veja de determinada forma ${ }^{316}$.

Forst diz: "eu não acredito em corpos como entidades separadas não cognitivas nesse contexto [de justificação]"317. A formação de crenças e corpos ocorre da mesma maneira, ele estabelece que são apenas diferentes faces de um mesmo processo. Ou seja, há um componente de formação crítica de razão dentro da constituição corporal de afetos que farão parte da racionalização dos espaços de troca $^{318}$. Não significa dizer que os corpos não sejam objetos de dominação e violência. $\mathrm{O}$ argumento se desenvolve no sentido de que os corpos, nos espaços políticos de troca de razão, são também instrumentos racionalizadores comunicativos. Afinal, o que seria um corpo em uma manifestação popular ocupando determinada avenida de grande movimento? O corpo é o instrumento de poder utilizado para oferecer as razões que são levantadas contra determinada ação do poder público, estabelecendo-se como verdadeiro instrumento discursivo. Da mesma forma, sem deixar de ser um processo discursivo as opressões físicas de um estado policial podem se estabelecer sobre o corpo e os afetos, tolhindo comportamentos e atitudes e fechando o espaço de troca de razões através da dominação.

Há uma diferença entre violência e coerção, na primeira, não há qualquer alternativa para sujeito passivo, enquanto na segunda, ainda que se veja a presença do fator coercitivo, em tese, o agente tem opção de escolher ou sofrer a consequência. Por isso, a ideia de violência simbólica deve estar presente para se falar em estruturas de significados e crenças dominantes que se estabelecem de forma colonizadora hegemônica sobre a mente dos outros ${ }^{319}$.

${ }^{316}$ FORST, R., Noumenal Power, p. 19.

317 Tradução livre, no original, em inglês: “I don't believe in 'bodies' as separate non-cognitive entities relevant in this context." ALLEN, A.; FORST, R.; HAUGAARD, M., Power and Reason, Justice and Domination: a conversation, p. 22.

318 Ibidem, p. 19.

${ }^{319}$ Ibidem. P. 19-20. 
Dessa forma, Forst entende que a razão reflexiva é o único critério capaz de produzir soluções - ainda que falíveis - para uma crítica normativa social, já que os critérios imanentes e transcendentes se tornaram insuficientes. Precisa-se de uma noção de razão que desafie a dicotomia entre contextualismo e transcendência ${ }^{320}$. Nesta mesma linha, o espaço de trocas de razões é visto como um espaço de relações de poder com base em possibilidades de justificação de forma reflexiva. Se, por algum motivo, o espaço de trocas de razão é fechado, fica-se diante de estruturas de dominação e violência que suprimem o caráter intersubjetivo necessário para a coordenação de ações de uma comunidade. Forst ratifica a ideia de Habermas de colonização do mundo da vida afirmando que os sistemas financeiros e do dinheiro até possuem certa normatividade, mas são normas e (in)justificações que permitem que ações estratégicas desprezem determinadas normas éticas, atuando de forma dominadora sobre o mundo da vida; como se a ação social se tornasse objeto e o sistema passasse a regular os produtores, ao invés de ser regulado por eles ${ }^{321}$.

Por isso, quando penso no espaço político, enquanto espaço capaz de combater a colonização do mundo da vida, conforme argumentei no item anterior, digo que é nessa esfera que se deve exercitar as relações de poder orientadas para o entendimento, ainda que se pretenda influenciar o interlocutor. É preciso combater a regra - ou norma - sem adequadas justificações. Isso porque na esfera política, a dominação não assume outra forma, ela é a própria regra desprovida de qualquer justificação ou, numa forma reflexiva, é o processo de construção da norma em um procedimento desprovido de estruturas básicas de justificação ${ }^{322}$. $\mathrm{Na}$ verdade, as estruturas de poder sempre descambarão para dominação ou violência, se não houver, por parte do interlocutor, a aceitação das condições de submissão a que se coloca. Não pode haver coação ou violência, ou ainda violação ao princípio de justificação, uma vez que toda relação desse tipo fugiria da área de ação do poder para se tornar uma relação de dominação ${ }^{323}$.

${ }^{320}$ ALLEN, A.; FORST, R.; HAUGAARD, M., Power and Reason, Justice and Domination: a conversation, p. 21-22.

${ }^{321}$ FORST, R. Noumenal Power, p. 13 e16.

322 Ibidem, p. 23.

${ }^{323}$ Idem. 
Nesse argumento, está também um forte componente da virada linguística que Habermas atribui ao mundo pós-metafísico: ainda que se admita a existência do agir estratégico nas relações de poder, a exigência de uma aceitação racional do interlocutor demanda certo grau de comunicação típico do agir comunicativo. O que se revela claramente ao determinar que, no agir comunicativo, há uma preocupação com a compreensão da mensagem pelo interlocutor que, além de recebê-la, pode realizar juízos de validade e aceitação ${ }^{324}$.Dessa forma, o agir com fins apenas perlocutórios aproxima-se da caracterização de uma estrutura de poder carente de mecanismos de justificação, descambando para a dominação ${ }^{325}$.

Todos os aspectos, conceitos e critérios desenvolvidos até agora neste item estão inseridos na ideia de justiça de Forst, o princípio da justificação é um princípio normativo de justiça. Dessa forma, é preciso voltar-se para o cenário da presente pesquisa e introduzir os conceitos discutidos acima no ambiente políticodemocrático com problemas de desigualdade social. Num contexto de justiça, a distribuição de bens requer uma justificação, a de que os participantes de um contexto de cooperação sejam respeitados como iguais em sua dignidade, "e isso significa que eles são participantes iguais na ordem de justificação social e política", em que a produção e distribuição de bens são determinadas por sua participação $^{326}$.

Nesse sentido, seria impossível qualificar uma sociedade como democrática sem a presença de uma estrutura básica de justificação, sem que haja tolerância enquanto respeito e não apenas como permissão; e, sobretudo, onde haja dominação social em relação às classes mais pobres, tendo por base uma classe política ou uma elite extremamente minoritária e mais rica. Num contexto de larga desigualdade social - contexto de injustiça social -, em conjunto com um contexto de crise do sistema representativo da democracia, o princípio de justificação é incapaz de realizar-se com base nos critérios formulados por Forst. Para tanto, é necessário que os sujeitos se reconheçam intersubjetivamente,

${ }^{324}$ HABERMAS, J. O Pensamento Pós-metafísico p. 67.

${ }^{325}$ Ibidem, p. 108. Nesse sentido, parece haver relação entre o conceito de dominação de Forst e a colonização do mundo da vida de Habermas.

326 Tradução livre. No original, em inglês: "and this means that they are equal participants in the social and political order of justification". FORST, R., The Right to Justification: elements of a constructivist theory of justice, p. 192. 
enquanto sujeitos com direito à justificação e se permitam estabelecer estruturas básicas de justificação que alterem o status quo social.

Apesar dos mecanismos de participação direta serem o instrumento escolhido nesta pesquisa, para garantir uma melhora democrática com base na comunicação e no princípio da justificação, nada disso pode ocorrer sem se falar em reconhecimento. E isso não significa mudar da matriz filosófica de Forst para Honneth, até mesmo porque a justificação depende de contextos de interação e reconhecimento intersubjetivo entre os sujeitos, no espaço de trocas de razão. Se o eu não reconhece que o outro é capaz de participar de uma relação de poder consigo, ou que tem o direito à justificação, ele tende a fechar o espaço de troca de razões, transformando as relações de poder em dominação. Porém, é preciso dizer que reconheço, na perspectiva sociológica de Honneth, uma compreensão mais real de como as relações intersubjetivas podem ocorrer, fornecendo os instrumentos necessários para as lutas por reconhecimento que, em essência, são procedimentos emancipatórios capazes de ampliar as estruturas de justificação. Por esse motivo, retomo rapidamente a perspectiva de reconhecimento de Honneth, com todas as críticas estabelecidas por Forst, para compreender melhor como é possível melhorar o reconhecimento intersubjetivo típico de estruturas de justificação básicas ou desenvolvidas ${ }^{327}$.

O principal problema de Forst com as teorias do reconhecimento é encarálas como teorias de justiça, isso porque ele entende que as teorias do reconhecimento não demandam efetivamente uma apreciação ética do outro, apenas uma eliminação da discriminação. Na maioria das vezes, as problematizações de reconhecimento têm relação com desigualdades de tratamento e respeito, por exemplo, em relação às condições ou relações de trabalho. Trata-se mais de uma demanda de equidade do que uma demanda de justiça e reconhecimento ético, que pouco contribui para uma teoria normativa

\footnotetext{
327 Trata-se de um momento complicado na pesquisa. Em conversa com Forst durante pequeno período de visita ao Normative Order, Frankfurt, Alemanha, em Julho de 2015, ficou claro que ele acredita que sua perspectiva de justiça é incompatível do ponto de vista normativo e de justiça com as teorias de Honneth e Fraser. Aliás, isso aparece de diversas formas em trechos que citarei nos próximos parágrafos. Em sua base filosófica, faz sentido dizer que essas teorias são incompatíveis do ponto de vista do princípio moral, porém, no que toca a instrumentalidade que busco em relação às perspectivas democráticas e de desigualdade, acredito que não há problema em utilizar ferramentas dos três autores. A compatibilidade integral, prática e teórica, poderá um dia ser objeto de outra pesquisa, mas não invalida as elaborações que seguem nos próximos parágrafos.
} 
moral. O reconhecimento constitui-se numa linguagem que é incapaz de explicar as questões de justiça, por isso, é necessário que haja uma tradução através do princípio da justificação, uma ideia de reconhecimento recíproco e geral $^{328}$.

Forst diz que Honneth mistura os paradigmas transcendentes e imanentes numa teoria do reconhecimento com uma lógica antropológica e moral que pode resultar em experiências socialmente ruins ${ }^{329}$, ao mesmo tempo, critica as teorias distributivistas, como a de Fraser, por não possuírem os recursos normativos suficientes para tratar do procedimento democrático de acordo com a sua complexidade $^{330}$. Para Forst, todas as formas de não reconhecimento estão contidas dentro da categoria de injustas, ou seja, injustificáveis, até porque, para ele, igualdade e reciprocidade parecem ter um conteúdo muito similar ${ }^{331}$. Da mesma forma, não há como se falar em distribuição sem referência às relações de poder numa sociedade, justamente, porque o sujeito não pode ser paciente da justiça e sim agente $^{332}$.

É preciso que o sujeito seja agente autônomo dentro de uma noção não apenas filosófica, mas como algo básico e necessário para reconhecimento e respeito próprios ${ }^{333}$. A divergência com Honneth está principalmente no fator de que para Forst não seria necessária uma estima, mas a necessidade de ser reconhecido e respeitado como sujeito moral e político, o que inclui suas preferências éticas que não podem meramente ser toleradas como forma de permissão, o sujeito precisa ser compreendido como um sujeito com direito à justificação ${ }^{334}$, inclusive para resguardar suas características éticas.

Nesse ponto, é importante retomar que o reconhecimento compreende a perspectiva emancipatória da tolerância enquanto respeito. Por isso é preciso questionar certas formas de reconhecimento e rejeitar os falsos reconhecimentos que não tenham por base os critérios de justificação ${ }^{335}$.Um falso reconhecimento

\footnotetext{
${ }^{328}$ FORST, R. The Right to Justification: elements of a constructivist theory of justice, p. 193-194.

${ }^{329}$ Id., Justification and Critique: Towards a Critical Theory of Politics, p. 112.

${ }^{330}$ Id., The Right to Justification: elements of a constructivist theory of justice, p. 192.

${ }^{331}$ Id., Justification and Critique: Towards a Critical Theory of Politics, p. 118.

${ }^{332}$ Ibidem, p. 121.

${ }^{333}$ Ibidem, p. 124.

${ }^{334}$ Ibidem, p. 147.

${ }^{335}$ Ibidem, p. 127.
} 
para Forst seria a visão do sujeito apenas como um receptor da redistribuição e não como um agente independente de justiça ${ }^{336}$.

Mesmo com todas as críticas, em determinado momento, Forst parece se aproximar da perspectiva instrumental - que mencionei acima - de que as dimensões de reconhecimento de Honneth podem ser importantes na luta pela constituição de uma estrutura básica de reconhecimento, quando diz assim:

Portanto, lutas por reconhecimento são também lutas por justiça quando o objetivo é alterar [criar ou resgatar] as estruturas básicas de reconhecimento com respeito a essas dimensões [amor, respeito e estima] e desafiar, por exemplo, uma noção usual de conquistas e contribuições ${ }^{337}$.

Dessa forma, as categorias de reconhecimento de amor, respeito e estima aparecem como perspectivas de luta por reconhecimento em qualquer sociedade talvez utópico e pouco reflexivo - que precise se estabelecer intersubjetivamente, segundo as exigências de um mundo pós-metafísico ${ }^{338}$. Importante lembrar que neste ponto do trabalho, procura-se determinar um conteúdo material para as formas procedimentais democráticas que se pretende estabelecer através da institucionalização de mecanismos formais e procedimentais de participação política $^{339}$. Para tanto, nada mais interessante que conceber os aspectos instrumentais de uma luta por reconhecimento que acontece na forma da criação/alteração das estruturas de justificação existentes na democracia. Apesar de ser possível tratar as três dimensões de reconhecimento de forma genérica na busca pela subjetividade, a separação é produtiva. A partir do momento em que amor por pessoas pode ser separado do reconhecimento legal e da estima, pode-se enxergar desenvolvimentos de diferentes formas de luta social ${ }^{340}$.

Ao trabalhar com a tolerância como respeito e o princípio da justificação, Forst ora se aproxima e ora se afasta de Honneth. Aproxima-se ao considerar necessário o reconhecimento intersubjetivo entre sujeitos, seja enquanto sujeito com um direito à justificação, ou ainda quanto à necessidade de um

\footnotetext{
${ }^{336}$ FORST, R., The Right to Justification: elements of a constructivist theory of justice, p. 196.

${ }^{337}$ Tradução livre. No original, em inglês: "Struggles for recognition, then, are also struggles for justice when it is a matter of changing the basic structure with respect to these dimensions and so challenging, for, example, well-worn understanding of achievement or contribution”. FORST, R., The Right to Justification: elements of a constructivist theory of justice, p. 193.

${ }^{338}$ HONNETH, A., The Struggle for Recognition: The Moral Grammar of Social Conflicts, p. $175-179$

${ }^{339}$ FORST, R., Os limites da tolerância, p. 22.

${ }^{340}$ HONNETH, A., op. cit., p. 167-170.
} 
reconhecimento da comunidade ética estranha. Entende que o reconhecimento pressupõe a existência de uma luta para atingir o momento de uma tolerância como respeito, passada, presente ou futura, na verdade um respeito que seja capaz de conferir ao sujeito um direito à justificação. Assim, a constante luta por reconhecimento que se coloca entre comunidades éticas assume papel fundamental para alteração do status quo social, uma vez que, ao se estabelecer o reconhecimento da identidade/crença do outro, é possível garantir, mutuamente, direitos de participação capazes de alterar as estruturas de poder ${ }^{341}$.

As dimensões do amor, respeito e estima se apresentam neste teor: a afetiva (amor), que seria típica dos momentos familiares, em que as pessoas são reconhecidas como criaturas de necessidades básicas; a formal cognitiva (respeito), do campo do Direito, onde as pessoas são reconhecidas como sujeitos abstratos; a emocional (estima), reconhecida no Estado, em que sujeitos são reconhecidos como concretude universal, sujeitos socializados através de suas particularidades $^{342}$. Honneth divide o indivíduo, enquanto pessoa e enquanto sujeito, pressupondo que essas dimensões são, de alguma forma, escalonadas, dizendo que o amor seria pressuposto das formas de reconhecimento de respeito e estima. Porém, assim como as dimensões de reconhecimento de Honneth parecem ocorrer em paralelo à perspectiva de reconhecimento de Forst, as próprias dimensões de reconhecimento devem também ser encaradas de forma cooriginal $^{343}$.

É até possível pensar na dimensão do amor como preliminar, uma vez que o reconhecimento do outro, enquanto sujeito de necessidades é algo tão básico que, se o eu não lhe garante esse reconhecimento, provavelmente não lhe dará reconhecimento de nenhum tipo. Porém, ao mesmo tempo, existem certas necessidades do sujeito, ultrapassada a relação familiar, que são básicas e só podem ser conhecidas nos processos discursivos de troca de razão. Isso ocorre porque a gama de necessidades básicas das sociedades atuais vai muito além dos paradigmas liberais tradicionais de sociedades metafísicas ou de perspectivas contratualistas. Ou seja, avançando um pouco além do que Honneth pretende na

\footnotetext{
${ }^{341}$ FORST, R., Justification and Critique: Towards a Critical Theory of Politics, p. 109.

${ }^{342}$ HONNETH, A., The Struggle for Recognition: The Moral Grammar of Social Conflicts, p. 25.

${ }^{343}$ FASCIOLI, A., O Reconhecimento como Núcleo de Fundamentação da Normatividade: reflexões sobre a crítica de Honneth à ética do discurso habermasiana, p. 58.
} 
formulação de sua teoria, as necessidades básicas do sujeito precisam dos espaços de troca de razão para serem conhecidas pelos outros. Quando se fala em um cenário de desigualdades sociais, onde existem diversos mundos da vida, isso fica ainda mais evidente. Uma classe ou uma comunidade é incapaz de conhecer as necessidades das outras sem que haja um contato discursivo de sujeitos que se reconhecem como sujeitos de direito e sujeitos políticos; seria necessário que houvesse um reconhecimento nas dimensões de respeito e estima, assim como um reconhecimento com base na justificação para que se garantisse um reconhecimento em relação às necessidades básicas do sujeito. A mesma situação se estabelece em vetor contrário, uma vez que é preciso que o eu reconheça o sujeito em suas necessidades básicas para que passe a considerá-lo como sujeito de direito e partícipe da sociedade.

Soma-se a essa noção de cooriginalidade, o fato de que a teoria de Honneth também revela um forte componente emancipatório em relação à autocompreensão do sujeito. A intersubjetividade revelada por Honneth através da reconstrução de Mead e Hegel é elemento fundamental e necessário para que o próprio sujeito se entenda como tal. As dimensões de reconhecimento de amor, estima e respeito são pressupostos para que haja amor e respeito próprios, além da autoestima capazes de alçar o sujeito à condição de participante da comunidade política. Ocorre que a ascensão ao reconhecimento, enquanto sujeito político, possibilita ao sujeito a contestação das situações de desrespeito e falta de reconhecimento, o que revela uma melhora na relação consigo mesmo ${ }^{344}$.

Entendendo dessa forma, fica mais fácil compreender uma cooriginalidade de percurso entre o princípio da justificação de Forst, enquanto reconhecimento do sujeito como detentor de dignidade humana - justificação -, e o reconhecimento - ausência de não reconhecimento ou desrespeito - idealizado por Honneth. Isto é, não parece possível que se altere uma situação de dominação, sem que a relação de não reconhecimento dos grupos dominados se modifique através de uma luta por reconhecimento que considere as dimensões propostas por Honneth. Da mesma forma, o ideal de um reconhecimento que preencha todas essas dimensões estabelecidas por Honneth, enquanto princípio moral, não parece

${ }^{344}$ HONNETH, Axel., The Struggle for recognition, p. 164. Ponto que também foi comentado no primeiro capítulo. 
fácil de atingir. Sendo assim, a estrutura básica de justificação de Forst se mostra mais instrumentalizável e factível em contextos de reconhecimento, onde a tolerância como respeito seria inerente para certo reconhecimento intersubjetivo. Faz sentido dizer que a perspectiva sociológica de Honneth apresenta os instrumentos necessários para a efetivação da perspectiva política reflexiva de Forst e vice-versa.

Nesse sentido, vê-se que a intersubjetividade necessária para o autorreconhecimento e até mesmo para um reconhecimento como sujeito com direito à justificação passa pelo processo de construção da subjetividade política de amor e respeito próprios, além de autoestima. No caso brasileiro, onde o abismo social existente é largo e profundo, a ausência de um reconhecimento social se espraia sobre toda a estrutura de poder entre classes e entre Estado e cidadão. A elite e classe política não reconhecem as classes mais pobres como cidadãos com direitos à justificação, tampouco há uma relação intersubjetiva que possa dar margem às dimensões de reconhecimento de Honneth.

Partindo do pensamento de Honneth, em que a formação subjetiva passa pela necessidade de se compreender como sujeito, a partir das reações do outro, vê-se que a classe dominada - os mais pobres - encontra-se imobilizada em suas possibilidades de demandar um direito à justificação. Isto porque a ausência da relação intersubjetiva entre sujeitos de diferentes classes constrange a formação e a autoafirmação do pobre enquanto sujeito político. Na verdade, forma-se uma falsa estrutura de justificação que permite a manutenção do status quo e a ausência de mudanças estruturais, tudo isso é, ao mesmo tempo, causa/resultado de um modelo baseado em representatividade que não representa as classes desfavorecidas e, portanto, carece de legitimidade e comunicação.

Quando Forst propõe que o princípio da justificação deve ser base da construção de mecanismos capazes de promover a relação de poder intersubjetiva ${ }^{345}$, trata-se propriamente de mecanismos que aproximem o sujeito das instituições de poder através de estruturas básicas de justificação. Isso é impossível em modelos baseados exclusivamente na representação,

${ }^{345}$ FORST, R. The Right to Justification: elements of a constructivist theory of justice, p. 199-200. 
principalmente, em países de grande desigualdade social. Recuperando a relação entre o princípio da justificação e a democracia, Forst diz:

Uma democracia reflexiva, aquela consciente de seus próprios princípios, deve estar baseada no fundamental princípio de justificação da justiça, o qual diz que todas as instituições que determinam a vida social e, por conseguinte, as vidas individuais dos cidadãos de modo considerável precisam ser justificáveis à luz de normas que os cidadãos não possam recíproca e genericamente rejeitar ${ }^{346}$.

A democracia está baseada em uma forma de justiça participativa que procura traçar caminhos para a realização efetiva de um estrutura básica de justificação. Para isso, Forst elenca diversos caminhos a serem percorridos; em todos eles, há uma coisa em comum, a necessidade de aumentar as formas de participação e os espaços de troca de razão. Mas dentro do elenco, encontra-se a necessidade de aumentar a distribuição de trabalho e a possibilidade de participação daqueles que têm a menor capacidade e potencial para influenciar as tomadas de decisões, possibilitando à classe trabalhadora influenciar nas decisões econômicas ${ }^{347}$.

Isso significa que as abordagens da justificação e de uma sociedade justa se relacionam com os problemas de exclusão e inclusão, dentro de um aspecto político reflexivo, em que a inclusão trate de participação, enquanto sujeitos ativos da sociedade, com espaço para troca de razão, inclusive e principalmente sobre a distribuição dos bens de produção ${ }^{348}$. O princípio da justificação de Forst se apresenta como método preocupado com a institucionalização de mecanismos capazes de resguardar o caráter democrático e inclusivo do sistema ${ }^{349}$. Para a presente pesquisa, essa institucionalização é concretizada através da amplificação do diálogo, do discurso argumentativo e da inserção de todos no procedimento decisório com a implementação de mecanismos de participação popular direta.

Encerrando o segundo capítulo, cabe uma breve recapitulação de como as teorias de Habermas e Forst - e porque não Honneth - são marcos teóricos desta pesquisa. Utilizando a teoria da ação comunicativa de Habermas, defendeu-se que não há democracia, quando as ações no espaço político são realizadas apenas com o agir estratégico, sem qualquer fim de entendimento. $\mathrm{O}$ sistema representativo

\footnotetext{
${ }^{346}$ FORST, R. Os limites da tolerância, p. 22.

${ }^{347}$ Id. The Right to Justification: elements of a constructivist theory of justice, p. 199-200.

${ }^{348}$ Idem.

${ }^{349}$ Idem.
} 
carece de espaços que possibilitem e privilegiem o agir comunicativo, ao mesmo tempo que produz poucos espaços de troca e de encontro que permitiriam o combate ao agir estratégico. Para se falar em democracia, é preciso inverter o vetor da colonização do mundo da vida, o que pode ocorrer na esfera política com a inserção de mecanismos de participação direta. Ao seu turno, Forst apresenta o princípio da justificação como seu princípio de justiça. Para ser justa, uma sociedade deve possuir, pelo menos, estruturas básicas de justificação baseadas em uma tolerância como respeito que não faça distinção entre as diferenças éticas dos participantes. Essas estruturas de justificação estabelecem relações de poder que permitem que um agente influencie o outro dentro dos espaços de troca de razão, desde que o interlocutor seja capaz de emitir enunciados de validade. Caso haja supressão dessa possibilidade e desses espaços, o agente se transforma em sujeito passivo e a relação de poder descamba para dominação. A dominação típica de uma estrutura social sem justificação é incompatível com a noção de democracia, uma vez que a dominação imobiliza a racionalidade do sujeito e o impede de participar como cidadão político das decisões que lhe dizem respeito. Por fim, há um forte componente da luta por reconhecimento na formação de estruturas básicas de justificação, principalmente em países de grande desigualdade social, já que os abismos colocados entre as classes impedem um reconhecimento intersubjetivo em todas as dimensões e impossibilitam o encontro e a troca necessária para as tomadas de decisão numa democracia. Os mecanismos de participação direta aparecem como caminho possível para aumentar a comunicação e as possibilidade de troca capazes de gerar reconhecimento e estruturas de justificação, o que se pretende elaborar melhor no último capítulo. 


\section{3. Reconstruindo o Modelo Democrático: Comunicação, Reconhecimento e Justificação}

Após os dois primeiros capítulos, já se estabeleceu que há um déficit democrático nos modelos políticos ocidentais oriundos de suas características exclusivamente representativas, das formas de governos que afastam os cidadãos do Estado e das desigualdades sociais que evidenciam contextos de não reconhecimento intersubjetivo. $\mathrm{O}$ cenário brasileiro mostrou-se categórico para ilustrar estes problemas, além de comprovar as ausências discursivas do modelo político que aparecem nos contextos de corrupção do discurso. A teoria da ação comunicativa, que privilegia o agir para o entendimento em detrimento do agir estratégico nas relações sociais para gerar coordenação, torna mais fácil defender a necessidade de que os espaços decisórios governamentais sejam configurados por encontros e discussões diretas que dificultam a utilização do agir estratégico típico dos sistemas financeiros e burocráticos. Além disso, o princípio da justificação orienta para a necessidade de uma estrutura básica de justificação como qualidade inerente de uma democracia. Os sistemas políticos exclusivamente representativos são incapazes de privilegiar os discursos comunicativos e as estruturas de justificação. Dessa forma, os mecanismos de participação direta aparecem como solução possível, em que seria mais fácil combater a colonização do mundo da vida que ganha força com a permanência do agir estratégico no meio político.

Neste último capítulo, a ideia é retomar alguns pontos levantados nos capítulos anteriores para demonstrar como é possível aumentar a qualidade democrática do sistema político e conferir-lhe legitimidade, através da aproximação do cidadão do espaço público decisório e da diminuição da distância entre representante e representado. Para isso, é preciso pensar numa noção democrática reconstruída com base nos cenários empíricos apresentados e nas teorias críticas discorridas até aqui. Chama-se de modelo reconstrutivista democrático já que não se apresenta nenhuma inovação institucional e tampouco teórica. É através dos mecanismos democráticos existentes e das teorias deliberativas e discursivas da democracia que se propõe uma outra forma de se 
pensar a legitimidade democrática. Ainda nesse ponto, fala-se em reconstrução por se apoiar na defesa de um modelo misto entre representação e participação direta. Isto porque a representação não é um mal em si mesma, apenas se tornou ou sempre foi - insuficiente para as necessidades e expectativas normativas de todos os sujeitos que compõem as sociedades plurais e multiculturais dos dias atuais. Deve-se então pensar em caminhos democráticos que não abandonem as instituições democráticas, mas repensem suas possibilidades e qualidades. A inserção de mecanismos de participação direta parece ser uma das formas de aumentar a legitimidade do sistema democrático, ela atende às aspirações teóricas e empíricas levantadas ao longo da presente pesquisa. Porém, ainda assim, não se pretende achar a solução democrática para o sistema, nem talvez dizer que é a melhor das alternativas dentre as correntes críticas relativas às democracias representativas ${ }^{350}$, mas parece apenas ser um caminho possível.

No primeiro item, retorna-se ao problema da representação sem repetir o que já foi dito no primeiro capítulo, tratando mais especificamente da insuficiência do modelo representativo de conferir legitimidade democrática ao Estado, o que foi escrito como conclusão no primeiro capítulo e fornece a ponte para sua elaboração aqui. No segundo item, tenta-se responder onde deveriam estar as preocupações responsivas do sistema para conferir legitimidade decisória ao Estado. Retomando noções do primeiro capítulo, a governabilidade deve legitimar-se no poder constituinte e não em acordos controversos que só comprometem a democracia. Por fim, o último item apresenta a necessidade de institucionalização do discurso através dos mecanismos de participação direta,

350 Digo isto porque as soluções apresentadas parecem se encaixar nas noções de democracia deliberativa, se colocadas dentro do estado da arte da teoria política e da teoria crítica. Entretanto, como se verá ao longo do capítulo, muitas das críticas incorporadas ao trabalho advêm de teorias da democracia radical que rechaçam a possibilidade de consenso e afirmam que a democracia só pode ocorrer em contextos de permanente conflito. Haverá alguma elaboração sobre a questão mais à frente, porém, é necessário registrar que não ignoro essas abordagens e tampouco discordo da dificuldade - ou até mesmo impossibilidade - de se atingir um consenso nas sociedades plurais dos dias de hoje. Tampouco ignoro a noção de que o consenso tem, historicamente, o problema de causar exclusão de grupos minoritários ou sub-representado. Tento resolver esse problema com a utilização do conflito dentro dos mecanismos de participação direta, mas não consigo fugir da necessidade de se obter algum resultado que gere compromisso mútuo entre os participantes do debate e concordo com a noção habermasiana de que é necessário que haja algum consenso linguístico pré-existente para que haja comunicação, ou que essa ausência seja suprimida através de instituições democráticas. Em resumo, os caminhos democráticos que apresento procuram, nas palavras de Boaventura, democratizar a democracia. Se isso é impossível e precisamos de uma revolução que quebre o sistema existente e acabe com todos os consensos forjados para que se suprimam os contextos de injustiça social, eu deixo essa resposta para outras pesquisas. 
explica a forma como se entende essa institucionalização e de que maneira ela se apresenta como solução possível para diminuir o déficit democrático do sistema político.

\section{1.}

\section{A insuficiência do modelo representativo}

Por que não iniciar de onde parei, no primeiro capítulo: a representação parlamentar e política não representa, nem quantitativamente e nem qualitativamente, a pluralidade social e econômica da sociedade, nesse caso do Brasil. Mesmo na defesa da democratização do sistema representativo que se pretende fazer neste capítulo, não significa dizer que os parlamentos se tornarão representativos de todas as parcelas da sociedade, eles nunca serão ${ }^{351}$. O objetivo é procurar caminhos, através de espaços de troca de razão, debate e encontro que consigam reduzir a característica excludente que o processo decisório, apenas representativo, adquiriu historicamente ${ }^{352}$.

Parece evidente dizer que o modelo representativo está ancorado em uma relação de justificação insuficiente que se apresenta diante de estruturas de subordinação, partindo de uma ideologia distorcida das relações sociais. Em suma, são oferecidas péssimas razões de justificação da estrutura normativa que jamais seriam aceitas por agentes que não estivessem submetidos a uma prática de justificação assimétrica e distorcida ${ }^{353}$. Nessa relação, há uma conotação negativa do poder, transformando-o em dominação, isso porque a representação que poderia ser uma ordem justificada torna-se o contrário, por impedir que se estruturem relações de troca de razões críticas. O poder, quando não é dominação, pressupõe um espaço problematizador de justificação que parece ausente nos modelos representativos. É possível até dizer que existe muita crítica no cotidiano da sociedade, mas os atores e agentes do sistema político fecham a possibilidade de troca com o exterior ao estabelecerem processos decisórios sem diálogo 354 .

\footnotetext{
${ }^{351}$ DAHL, R. A., Polyarchy: Participation and Opposition, p. 22.

352 POGREBINSCHI, T., The Pragmatic Turn of Democracy in Latin America, p. 8.

${ }^{353}$ FORST, R., Noumenal Power, p. 10.

${ }^{354}$ Id., Justification and Critique: Towards a Critical Theory of Politics, p. 103.
} 
Essa problemática dos modelos representativos, conforme já registrado, também se agrava nos contextos de desigualdade social, onde há diferentes contextos de entendimento preliminar. As grandes desigualdades sociais que se revelam em estratificações sociais e guetos físicos e ideológicos impedem um consenso linguístico preliminar à comunicação necessária para as ações coordenadas. Nesse sentido, uma estrutura representativa pouco dialógica dificulta e impede ainda mais a troca de razões necessária para contextos de justificação, recomendando uma concepção pragmática de justificação, enquanto prática, no espaço público, capaz de comportar críticas de validade e troca de razões ${ }^{355}$, para que se desenvolva plenamente a capacidade de comunicação entre os diferentes mundos da vida.

Contrariamente, o modelo representativo atual não tem interesse em abrir espaço para o diálogo com o cidadão de diferentes contextos de mundo da vida e para interação entre os próprios. Ele parte da lógica liberal de representação de que o representante é capaz de assumir uma perspectiva neutra para falar em nome dos representados, mesmo que não tenha, em momento algum, participado das experiências de conflito necessárias para um reconhecimento intersubjetivo.

Não há ninguém neutro, as crenças são norteadoras das ações, até mesmo porque são elas que forjam as percepções da realidade. Por cada pessoa ter diferentes impactos nas decisões políticas, é necessário saber quais as crenças de cada $u^{356}$, isso é requisito principal em relação aos representantes de um Estado democrático. $\mathrm{O}$ eu não pode mais representar uma instância cognitiva neutra, deve incorporar uma instância moral intersubjetiva de resolução de $\operatorname{conflitos}^{357}$, apresentando-se como tal para que se submeta às possibilidades críticas do outro.

É necessário trazer o outro para o cenário político decisório, a representação não é capaz de suprir a carência de intersubjetividade existente em sociedades desiguais. As falsas classificações do outro, da cultura, dos padrões éticos e tradicionais dos sujeitos estranhos resultam em intervenções baseadas em normalizações, que acabam por descambar em discriminações subalternizadoras

${ }^{355}$ HABERMAS, J., The Inclusion of the Other, p. 37.

${ }^{356}$ DAHL, R. A., Polyarchy: Participation and Opposition, p. 125-126.

${ }^{357}$ HONNETH, A., The Struggle for Recognition: The Moral Grammar of Social Conflicts, p. 77. 
dos diferentes e, ao invés de garantir-lhes liberdade, privam-nos dela ${ }^{358}$. A lógica democrática, que demanda contextos de comunicação, justificação e trocas de razões entre os diferentes, acaba comprometida pela noção liberal de representação. Chantal Mouffe diria que existe uma tensão fundamental entre a lógica democrática e a lógica liberal ${ }^{359}$.

Não há dúvida de que o modelo liberal político transforma o espaço público em um local de disputa para captura e preenchimento das posições de poder. Nesse sentido, os espaços de formação de vontade se dão de forma competitiva e estratégica com o único objetivo de assumir as posições administrativas, sem orientação para o entendimento ${ }^{360}$. Isso torna o modelo político excludente do diferente e daquele que não se vê como sujeito capaz de participar desses "processos competitivos estratégicos", já que não é reconhecido como tal pelos outros.

Há uma forte presença da noção de invisibilização de determinados sujeitos, através da ausência de reconhecimento que se encerra em uma incapacidade de autorreconhecimento, enquanto sujeito partícipe da sociedade. A negativa das estruturas de justificação, nesse ponto, inviabiliza a formação identitária do sujeito. Porque, na linha de Honneth, as fases - em que o sujeito primeiro se vê como objeto, para depois começar a se ver como sujeito de produções práticas, diante das obrigações intersubjetivas ${ }^{361}$; sentir-se reconhecido como sujeito de necessidades básicas pelo outro, com o qual se vê unido em relações intersubjetivas, gerando a autoconfiança necessária para se tornar capaz de participar como igual na formação da vontade política - simplesmente não se implementam ${ }^{362}$.

Dahl alerta para a uma observação anônima que afirma que todo regime é dominado por uma minoria que exerce o $\operatorname{poder}^{363}$. Certamente não se acredita que a frase é verdadeira ao incluir todos os regimes, mas nesse caso, as formações de vontade, através de competições estratégicas que ocorrem apenas em um contexto

${ }^{358}$ HABERMAS, J., The Inclusion of the Other, p. 209.

${ }^{359}$ MOUFFE, C., Deliberative Democracy or Agonistic Pluralism, p. 9.

${ }^{360}$ HABERMAS, J., op. cit., p. 243.

${ }^{361}$ HONNETH, A., The Struggle for Recognition: The Moral Grammar of Social Conflicts, p. 34.

362 Ibidem, p. 38 e 95.

${ }^{363}$ DAHL, R. A., Polyarchy: Participation and Opposition, p. 17. 
limitado e hermético à participação popular e à incorporação do outro ${ }^{364}$, permitem afirmar que há uma situação de dominação. Há um fechamento do espaço de trocas de razão e a supressão do conflito necessário para que se conheça e se relacione com os desejos do outro, isso porque está claro o pressuposto do reconhecimento intersubjetivo de que o conflito exista em algum grau, até mesmo para que se conheça as necessidades e desejos do outro ${ }^{365}$.

A vida pública deve aparecer como um envolvimento moral de pessoas responsáveis que precisam, para participar dos processos de formação de vontade, ter assegurada a oportunidade de participação. Esse reconhecimento legal não se insere apenas na preservação de direitos negativos de liberdades típicas de um modelo liberal representativo. Trata-se da necessidade de real possibilidade de participação, que significa poder aproveitar a posição em que se coloca, o que não ocorre sem um mínimo padrão de vida ${ }^{366}$; diga-se de passagem, inexistente em países de grande desigualdade social nos quais o modelo representativo tem sido incapaz de enfrentar o problema social ${ }^{367}$.

Quanto mais se analisam os modelos exclusivamente representativos, mais fica evidente que se trata de um espaço público que não é poroso à participação e à discursividade, seja através de argumentos ou utilizações do corpo, de forma que acaba apenas reproduzindo a dominação daqueles que controlam o processo de produção verbal $^{368}$. Isso porque a vida pública, no modelo liberal representativo, é vista como resultado da restrição da vida privada, o que contraria a noção de Forst de que a tolerância como respeito demanda a possibilidade do exercício das éticas individuais em espaço público ${ }^{369}$, bem como a afirmação de Honneth de que a vida pública deve ser a possibilidade de adimplir cada liberdade individual dos sujeitos, através de um processo de integração capaz de realizar verdadeiramente a liberdade $^{370}$.

\footnotetext{
${ }^{364}$ MATOS, A. R., "Eu participo, tu participas...nós protestamos": ações de protesto, democracia e participação em processos de decisão, p. 131.

${ }^{365}$ HONNETH, A. The Struggle for Recognition: The Moral Grammar of Social Conflicts, p. 42.

${ }^{366}$ Ibidem, p. 117.

${ }^{367}$ PERES, P. S., A barganha nas vísceras do modo brasileiro de governar, p. 3.

${ }^{368}$ AVRITZER, L.; COSTA, S., Teoria Crítica, Democracia e Esfera Pública: Concepções e Usos na América Latina, p. 713.

${ }^{369}$ Vide item 2.2.

${ }^{370}$ HONNETH, A., op. cit., p. 13.
} 
A limitação da democracia representativa é notória, sabida e incapaz de resolver os problemas de participação social e reconhecimento. É necessário pensar na ideia de representação justa, que levanta a bandeira de que os grupos marginalizados dependem de suas presenças nos órgãos decisórios para se considerarem representados ${ }^{371}$. Os modelos exclusivamente representativos são incapazes de conferir ao interlocutor - o cidadão - a possibilidade de levantar questões em relação às condições de validade da fala - dos agentes ou classe política - e "sem a possibilidade de tomadas de posição do estilo sim/não, o processo comunicativo permanece incompleto" ${ }^{\text {372 }}$. É possível afirmar que, num contexto de dominação da democracia liberal representativa, é injusto que alguns indivíduos ou grupos não sejam reconhecidos como participantes na interação social em razão de uma discriminação colocada pelos padrões políticos institucionalizados que lhes conferiram um lugar subalterno, na estratificação da sociedade em que vivem ${ }^{373}$.

O modelo representativo não implica a necessidade de estar sempre de acordo com aquele que foi escolhido democraticamente para governar. Para isso, é necessário que se amplifiquem os espaços de participação na vida política que são poucos nas democracias representativas ${ }^{374}$, sob pena de manter ignoradas as classes atualmente dominadas ${ }^{375}$ e retirar completamente a legitimidade do sistema. Isso só pode ocorrer, se o espaço público tiver por base uma noção de justificação baseada nos princípios normativos de generalidade e reciprocidade,

\footnotetext{
${ }^{371}$ POGREBINSCHI, T., Democracia Pragmática: Pressupostos de uma Teoria Normativamente Orientada, p. 673.

${ }^{372}$ HABERMAS, J., Pensamento Pós-Metafísico, p. 152.

${ }^{373}$ FRASER, N.; HONNETH, A., Redistribution or Recognition? A political-philosophical exchange, p. 29.

${ }^{374}$ MATOS, A. R., "Eu participo, tu participas...nós protestamos": ações de protesto, democracia e participação em processos de decisão, p. 119-121.

375 "O fato é que os discursos e práticas morais das classes dominadas não são registrados como normativamente relevantes resulta de uma combinação de elementos econômicos e socioculturais que excluem estas classes dos recursos que lhes permitiram expressar suas experiências de injustiça de forma aceitável, segundo regras exigentes do discurso público. Poderia se entender como 'desativação social' fenômenos que são, na realidade, resultado da invisibilidade de conflitos, gerada pela integração capitalista, e desigualdades no acesso aos recursos simbólicos para a elaboração de convicções normativas." FASCIOLI, A., O Reconhecimento como Núcleo de Fundamentação da Normatividade: reflexões sobre a crítica de Honneth à ética do discurso habermasiana, p. 51.
} 
em que os sujeitos não pretendam projetar suas razões sobre os outros, mas justificá-las discursivamente ${ }^{376}$.

Caso contrário, há uma perpetuação do status quo, em que apenas um lado tem motivo para aceitar obrigações recíprocas, justamente pelo fato de que é o privilegiado pelo modo de interação regulada ${ }^{377}$. De outro lado, estarão apenas os sujeitos prejudicados pela ausência de um reconhecimento intersubjetivo, que podem encontrar formas de reagir e transformá-las em lutas por reconhecimento $^{378}$; ou, em uma outra leitura de Honneth, diante de sentimentos éticos afetados pela humilhação e injustiça, decepcionados por expectativas não cumpridas, transformar a vergonha, a repulsa e a humilhação em uma desconstrução da própria identidade ${ }^{379}$.

Um dos pontos que não foi destacado no primeiro capítulo e é imprescindível para o desenvolvimento do argumento, é a pergunta de como identificar as classes, grupos e sujeitos dominados. Como é possível, nos dias de hoje, estabelecer qual é o sujeito a que é negado o direito de justificação, é negada a paridade de participação como igual nos processos decisórios e que não se reconhece como sujeito de necessidades básicas, como sujeito com direitos e nem com a estima de participante de uma sociedade?

Do ponto de vista prático, seria fácil identificar os cidadãos que sobrevivem com o mínimo necessários para comer, para ter moradia, entre outras necessidades básicas do pobre no Brasil; ou ainda falar de quem não possui nem o básico para sobreviver, o miserável. É possível identificar a população preta discriminada historicamente no Brasil, ou a disparidade de direitos e reconhecimento em relação às mulheres. Poderiam ser muitos os exemplos e alguns deles já foram tratados no primeiro capítulo. Nesse momento, é importante compreender, do ponto de vista das teorias normativas que se articulam, como seria possível formular as questões da perspectiva do sujeito dominado e injustiçado socialmente.

${ }^{376}$ FORST, R., The Right to Justification: elements of a constructivist theory of justice, p. 194.

${ }^{377}$ HABERMAS, J., The Inclusion of the Other, p. 15.

${ }^{378}$ HONNETH, A., The Struggle for Recognition: The Moral Grammar of Social Conflicts, p. 22.

${ }^{379} \mathrm{O}$ que facilita os contextos de dominação, através da perda da capacidade discursiva, inclusive a perda de capacidade de participar de processos discursivos. FASCIOLI, A., O Reconhecimento como Núcleo de Fundamentação da Normatividade: reflexões sobre a crítica de Honneth à ética do discurso habermasiana, p. 52. 
Está claro que para Forst o sujeito de injustiça é aquele a quem é negado o direito de justificação, a quem se impede a participação nos espaços típicos de troca de razão colocando-o em situação de pobreza e humilhação. Tudo isso foi dito no capítulo anterior. Aqui se coloca o problema de alienação social, um momento em que os modelos políticos representativos conseguem imobilizar de tal forma os cidadãos que os sujeitos dominados são capazes de compactuar ou não ter as forças necessárias para alterar a situação posta. É um verdadeiro cenário de dominação.

Utilizo uma porta aberta por Habermas, ao falar da colonização do mundo da vida e por Forst, ao estabelecer que há, nos dias de hoje, um problema de comodificação das relações sociais que geram um problema de alienação social ${ }^{380}$. Por essa porta e junto com outras noções de Fraser e Honneth, teoricamente herdeiros da escola de Frankfurt tanto como Forst, incorporo algumas críticas dos teóricos da democracia radical e da democracia pragmática para compreender a necessidade do conflito na democracia, ainda que, em última instância, ainda acredite na necessidade de um consenso normativo básico de justificação, com aspectos procedimentais, substanciais e da preexistência dos consensos linguístico necessários para a comunicação ${ }^{381}$.

Para falar de contextos históricos de dominação, que se perpetuam dentro dos supostos sistemas democráticos baseados exclusivamente na representação, deve-se registrar que a democracia representativa é capaz de preservar-se em sua essência, não apenas incapaz de incorporar as mudanças, mas capaz mesmo de resistir às investidas de propostas e críticas que desejem aumentar o caráter democrático do sistema ${ }^{382}$. Rancière diria que a ideia de um modelo institucional

\footnotetext{
${ }^{380}$ FORST, R., Noumenal Power, p. 15.

${ }^{381}$ Como informei na nota 350, faço uma escolha para um caminho de democratização da democracia através de estruturas teóricas normativas que trabalham com a noção de consenso, ainda que de forma procedimental e não substancial. Incluindo princípios morais que são incompatíveis com as teorias da democracia radical que rejeitam as possibilidades de um consenso racional. Entretanto, acredito que algumas críticas oferecidas pelos teóricos da democracia radical podem reforçar o argumento contrário a uma democracia exclusivamente representativa e em favor da necessidade de introduzir o diferente no processo decisório político, mesmo que por meio de estruturas normativas morais de justificação.

${ }^{382}$ POGREBINSCHI, T., Democracia Pragmática: Pressupostos de uma Teoria Normativamente Orientada, p. 680.
} 
representativo é a repressão do que o próprio sistema compreende como catástrofe da civilização democrática ${ }^{383}$.

Os contextos de dominação existem porque as elites que exercem historicamente o poder político não são portadoras de valores modernos e democráticos ${ }^{384}$. Há uma fórmula que permite manter os sujeitos de injustiça em estado de dominação que pressupõe uma operação tripla:

[...] em primeiro lugar, reduzir a democracia a uma forma de sociedade; em segundo lugar, identificar essa forma de sociedade com o reino do indivíduo igualitário, subsumindo nesse conceito todo tipo de propriedades distintas, desde o grande consumo até as reivindicações dos direitos das minorias, passando pelas lutas sindicais; e, em terceiro lugar, atribuir à 'sociedade individualista de massa', assim identificada com a democracia, a busca de um crescimento indefinido, inerente à lógica da economia capitalista. ${ }^{385}$

Trata exatamente do contexto de comodificação das relações sociais em que o novo sujeito é visto apenas como consumidor que identifica positivamente a relação de consumo com a democracia ${ }^{386}$. É o indivíduo narciso que passa a ignorar a típica noção de coordenação de ações do mundo da vida para assumir uma posição egoísta diante do todo, o que o faz aceitar os contextos de não justificação recíproca e geral da democracia representativa. A representação, que não é má em si mesma, torna-se o mecanismo de adaptação da democracia capaz de resguardar uma forma oligárquica de dominação de uma minoria que submete os demais a contextos injustificáveis de pobreza e de ausência de participação política $^{387}$. O discurso da democracia é corrompido a fim de enganar os cidadãos de que são sujeitos individuais, independentes de interação, afastando a necessidade do discurso e perpetuando os locais fechados à troca crítica. O sujeito perde sua característica de cidadão e ganha a qualificação de consumidor, "comprar algo que lhe parece feito sob medida é mais fácil do que juntar-se a um partido político ou movimento social para que um bem coletivo equivalente seja

${ }^{383}$ RANCIÈRE, J., O ódio à democracia, p. 11.

${ }^{384}$ AVRITZER, L.; COSTA, S., Teoria Crítica, Democracia e Esfera Pública: Concepções e Usos na América Latina, p. 721.

${ }^{385}$ RANCIÈRE, J., O ódio à democracia, p. 31.

${ }^{386}$ Ibidem, p. 34-35.

${ }^{387}$ Ibidem, p. 69-70. 
produzido - um bem que provavelmente seria igual para todos, como uma produção do fora de moda"388.

São as formas e práticas dos governos representativos oligárquicos que podem ser identificadas como menos ou mais democráticas, no sentido de relacioná-las aos contextos de dominação a que se submetem os demais sujeitos $^{389}$. A noção moral democrática ancorada em um princípio da justificação e em contextos de reconhecimento intersubjetivo é corrompida, através da institucionalização das ordens dos mercados e empresas que amplificam a anomia estereotipada dos agentes e restringem os espaços de manifestação individual $\operatorname{popular}^{390}$.

É possível ver que o sujeito de injustiça entra na luta com menos ou nenhuma arma para as lutas por reconhecimento - ao contrário do que encerram os valores liberais meritocráticos da democracia representativa -, enquanto as minorias têm todos os meios para perpetuar as estruturas injustificáveis existentes $^{391}$. Dessa forma, uma vez definidos os critérios normativos morais estruturantes da sociedade, tal qual o princípio da justificação, há uma expectativa normativa intersubjetiva que, quando frustrada, revela os contextos de injustiça que não cabem dentro de um ambiente democrático ${ }^{392}$.

Essa frustração e desapontamento com expectativas normativas geram a corrupção do discurso por parte dos agentes dominadores e a descrença nos espaços discursivos por parte do cidadão. O próprio discurso de que todos os políticos são corruptos - em moda nesses dias - é uma acusação de ausência de comprometimento democrático com o discurso, na verdade, é a incapacidade de gerar compromissos mútuos através da linguagem, abrindo-se mão dela enquanto meio de condução política ${ }^{393}$. O correto, na verdade, seria dizer que não é a relação entre as próprias palavras que é corrupta, mas a relação entre as palavras e

388 Tradução livre. No original, em inglês: "buying something that feels tailor-made for you is easier than having to join a political party or organize a social movement for an equivalent collective good to be produced - one which would probably be the same for all, like old-fashioned mass production." Conforme Wolfgang Streeck em CROUCH, C.; PORTA, D. d.; STREECK, W. Democracy in neoliberalism?, p. .506.

${ }^{389}$ RANCIÈRE, J., O ódio à democracia, p. 92.

${ }^{390}$ HABERMAS, J., Pensamento Pós-Metafísico, p. 228.

391 FRASER, N.; HONNETH, A., Redistribution or Recognition? A political-philosophical Exchange, p. 57.

392 Ibidem, p. 126-127.

${ }^{393}$ WARREN, M. E., Deliberative Democracy and the Corruption of Speech, p. 4. 
o compromisso, afinal, a corrupção do discurso é sempre parasitária da linguagem ${ }^{394}$. Os cidadãos retiram os pesos que as palavras deviam carregar e assim se destacam dos compromissos assumidos intersubjetivamente, afetando diretamente a crença na democracia e criando uma descrença endêmica nos sistemas exclusivamente representativos.

Dentro desse contexto de descrença no discurso, o desinteresse do cidadão se insere nas inadequações inevitáveis da representação, uma política rotineira sem qualquer poder de mobilização e que é incapaz de apresentar novas alternativas e nomes de lideranças. Ainda que se fale apenas de insuficiência de representação, coloca-se diante de um distanciamento grotesco entre representante e representado, que desqualificaria a legitimidade de qualquer sistema democrático ${ }^{395}$. Rancière oferece uma lista de itens contrários à ideia democrática que aparecem constantemente nas democracias representativas e no Brasil:

[...] eleitos eternos, que acumulam ou alternam funções municipais, estaduais, legislativas ou ministeriais, e veem a população como elo fundamental da representação dos interesses locais; [...] partidos financiados por fraudes nos contratos públicos; empresários investindo uma quantidade colossal de dinheiro em busca de um mandato; donos de impérios midiáticos privados apoderando-se do império das mídias públicas por meio de suas funções públicas. Em resumo: a apropriação da coisa pública por uma sólida aliança entre oligarquia estatal e econômica ${ }^{396}$.

A isso soma-se o fato de que as próprias eleições diretas dos representantes não são espaços de fala "dos debaixo" - sujeitos dominados. Trata-se de um consentimento do poder "dos de cima", originalmente, é uma permissão e não um respeito aos cidadãos, enquanto sujeitos com direito à participação ${ }^{397}$. Vê-se que a crise da democracia representativa é uma crise também da forma como é produzida a representação, o que demanda mais mecanismos legitimadores desse operador $^{398}$. Nos contextos de tolerância de Forst trata-se de uma mistura entre liberdade e dominação, exclusão e inclusão, reconhecimento e desrespeito. $\mathrm{Ou}$ seja, é a noção de tolerância como permissão que não cabe no ambiente

\footnotetext{
${ }^{394}$ WARREN, M. E., Deliberative Democracy and the Corruption of Speech, p. 14.

${ }^{395}$ PERES, P. S., A barganha nas vísceras do modo brasileiro de governar, p. 6.

${ }^{396}$ RANCIÈRE, J., O ódio à democracia, p. 93.

397 Ibidem, p. 69-70.

398 POGREBINSCHI, T., Democracia Pragmática: Pressupostos de uma Teoria Normativamente Orientada, p. 683-684.
} 
democrático de justificação, porque ela torna o receptor dependente do locutor em uma relação hierárquica ${ }^{399}$.

O sistema político lida com o reconhecimento legal de sujeitos como participantes dos processos decisórios de forma instrumental, o modelo representativo carece de fundamentos normativos justificadores que se consolidariam em espaços típicos do agir comunicativo ${ }^{400}$. O cenário de corrosão da aderência popular aos valores democráticos é construído diante da rejeição à política representativa partidária tradicional ${ }^{401}$. Sabe-se que quanto maior a crença na legitimidade das instituições democráticas maior a chance de uma democracia verdadeira se implementar ${ }^{402}$. Para que as instituições parem de impedir uma paridade de participação, é preciso desinstitucionalizar padrões ${ }^{403}$ que gerem esse tipo de bloqueio ${ }^{404}$.

Assim, a representação se coloca como operador institucionalizador de mecanismos de mediação entre governo e sociedade, sendo somente através de relações mediadas que os cidadãos têm contato com as arenas de decisão ${ }^{405}$. É por isso que "o desafio que se encontra em aberto é o de tornar as experiências participativas e deliberativas constitutivas das instituições representativas" ${ }^{406}$.

É preciso combater a esquizofrenia criada no Brasil, após a Constituição de 1988, que torna os contextos de amplificação de direitos e descentralização dependentes de um contexto histórico de aversão aos minipúblicos e à participação popular. A esquizofrenia que coloca, de um lado, o capitalismo informalizante, precarizador das relações de trabalho, financeirizado, e do outro

\footnotetext{
${ }^{399}$ FORST, R., Justification and Critique: Towards a Critical Theory of Politics, p. 129-130.

400 HABERMAS, J., Soberania Popular como Procedimento: um conceito normativo de espaço público, p. 109.

${ }^{401}$ MOUFFE, C., Deliberative Democracy or Agonistic Pluralism, p. 1.

402 DAHL, R. A., Polyarchy: Participation and Opposition, p. 129.

${ }^{403}$ A expressão "padrões culturais" é a tradução do termo utilizado por Fraser; mas, aqui colocaria como estruturas normativas injustificáveis, na linha de Forst.

404 FRASER, N.; HONNETH, A., Redistribution or Recognition? A political-philosophical exchange, p. 29.

405 WARREN, M. E., Deliberative Democracy and the Corruption of Speech, p. 24.

406 POGREBINSCHI, T., Democracia Pragmática: Pressupostos de uma Teoria Normativamente Orientada, p. 688.
} 
lado, a Constituição democrática, descentralizadora, elogiosa da participação popular e da amplificação de direitos, precisa ser remediada ${ }^{407}$.

Precisa-se de um movimento democrático de transgressões de limites capaz de "estender a igualdade do homem público a outros domínios da vida comum" e de "reafirmar o pertencimento da esfera pública incessantemente privatizada a todos e qualquer um"408. Ou, como diria Ana Raquel Matos em relação aos protestos, precisa-se movimentos que representem estratégias de comunicação participativa a surgir entre os atores sociais quando o diálogo com o Estado está comprometido $^{409}$.

Buscando as experiências dos minipúblicos, é necessário travar a desconstrução dos estados de dominação da democracia representativa em que as relações deixaram de ser subjetivas para ser comodificadas; quebrar a potência centralizadora dominadora e sua aposta estratégica; e acabar com os espaços de injustificação hierarquizados, reestabelecendo a possibilidade de ações coordenadas no âmbito decisório político ${ }^{410}$. Mesmo que, culturalmente não haja respaldo para a delegação do poder e uma justificação mentirosa do privilégio do conhecimento técnico em detrimento do popular que continua a defender a necessidade da representação pelos melhores ${ }^{411}$.

Para isso, é preciso reativar as intenções democratizantes, descentralizadoras e inauguradoras de direitos da Constituição de 1988, garantindo uma melhora no reconhecimento intersubjetivo, na comunicação e nas estruturas de justificação. Deve-se alterar o padrão de legitimidade e construção de poder baseado em uma lógica representativa de acordos "dos de cima", deslocando essa legitimação do processo decisório para a participação direta dos cidadãos diferentes eticamente, permitindo um conflito discursivo que gere os sentimentos de pertencimento e justificação. É sobre isso que abordará o próximo item.

\footnotetext{
407 FONSECA, F., Democracia e participação no Brasil: descentralização e cidadania face ao capitalismo contemporâneo, p. 246-250.

${ }^{408}$ RANCIÈRE, J., O ódio à democracia, p. 75.

${ }^{409}$ MATOS, A. R., "Eu participo, tu participas...nós protestamos": ações de protesto, democracia e participação em processos de decisão, p. 123.

${ }^{410}$ MARTINS, P. G.; GONTIJO, L. de A., Teoria do Reconhecimento e Economia Solidária: uma proposta de recomposição entre igualdade e solidariedade, p. 214.

${ }^{411}$ Ibidem, p. 207.
} 


\section{2. \\ Participação como Fiadora da Governabilidade}

Uma vez que a proposta da pesquisa não é desmontar completamente a estrutura representativa dos modelos políticos, mas torná-la mais democrática, é importante para o argumento em favor dos mecanismos da participação direta retomar a questão da governabilidade. Isso porque, ainda que seja necessário pensar em formas de governo que privilegiem o pluralismo e o conflito como plataforma para um procedimento decisório inclusivo, esquecer a necessidade de governabilidade seria condenar os modelos políticos atuais ao engessamento, à indecisão e à ineficácia. O que, por si só, contraria qualquer noção de necessidade de vida em sociedade que precise se movimentar através de ações coordenadas ${ }^{412}$.

No primeiro capítulo tratou-se da questão do presidencialismo de coalizão como necessidade para formar as maiorias que possibilitassem a governabilidade e como esses processos foram fundamentais em apresentar uma lógica deslegitimadora do sistema, aumentando a descrença dos cidadãos em relação à política e à representação. Por isso, é necessário saber se há possibilidade de defesa de um modelo misto que não abandona a representação, em que deverá ser buscada uma outra forma de governabilidade.

O argumento já apresentado no primeiro capítulo será desenvolvido neste item. É necessário deslocar a composição da governabilidade para a participação popular, acabando com uma legitimação injustificável do governo que ocorre através de acordos financeiros e administrativos sem qualquer conhecimento da população. Essa lógica de acordos e composições de governo gera uma surdez em relação ao poder constituinte, apresentando uma relação exclusivamente bipolar em que atuam apenas os atores políticos e o mercado. No Brasil, esse fenômeno se colocou em todos os momentos de acirramento entre situação e oposição, com a contraposição, até o impedimento presidencial de 2016, entre governo e oposiçãomídia. Ambos os lados permaneceram comprometidos com a manutenção das discussões abstratas e estratégicas, enquanto uma demanda por comunicação,

\footnotetext{
${ }^{412}$ A resistência é a maneira para trazer à luz as formas de poder. Mas, o objetivo não é atacar uma instituição de poder em específico, sim a forma pela qual o poder se constrói [como dominação]. FOUCAULT, M., The Subject and Power, p. 329-331.
} 
entendimento e justificação ainda se amontoa do lado de fora das paredes dos três poderes $^{413}$.

É preciso que a mudança do paradigma legitimador da governabilidade seja capaz de acabar com o clientelismo existente nos acordos típicos do presidencialismo de coalizão. A possibilidade da introdução da instersubjetividade entre os sujeitos e o estado que garante o apoio necessário para aprovação e implementação da agenda governamental, representa uma mudança nos padrões de relacionamento político das comunidades ${ }^{414}$.

É a viabilidade de ressignificar o conceito de representação ${ }^{415}$, incluindo, necessariamente, um entendimento de que a legitimação de um governo depende de que sua capacidade de governar - governabilidade - esteja apoiada no povo, não em acordos clientelistas entre partidos. O que não ocorre na América Latina:

Na América Latina, contudo, os partidos se constituíram, historicamente, a partir de máquinas partidárias capazes de distribuir privadamente e por meio de acordos clientelistas, benefícios públicos. Nesse sentido, cabe uma ênfase distinta nas articulações entre os processos de deliberação pública e tomada de decisão na América Latina. É preciso que, no seio de uma esfera pública porosa e pulsante, temas, posições e argumentos trazidos pelos novos atores sociais encontrem formas institucionais de penetrar o Estado e, por essa via, democratizá-lo, tornando-o objeto de controle dos cidadãos ${ }^{416}$.

Como tratado no item anterior, no Brasil e no mundo, há certa esquizofrenia em relação ao problema da institucionalização dos mecanismos de participação em contraposição a um movimento neoliberal que pretende comodificar todo tipo de relação pessoal e social. No mundo atual, há uma substituição das normas responsivas à vontade popular por uma estruturação lógica de sistemas e de redes invisíveis da economia global. Revelando que os custos dessa troca só comprometem a confiança nas estruturas democráticas ${ }^{417}$. No Brasil, por exemplo, a história mostra que a participação não foi conferida aos membros da federação,

${ }^{413}$ PILATTI, A.; COCCO, G., Quem tem medo do poder constituinte?

${ }^{414}$ PERES, P. S., A barganha nas vísceras do modo brasileiro de governar, p 5.

415 POGREBINSCHI, T., Democracia Pragmática: Pressupostos de uma Teoria Normativamente Orientada, p. 664.

${ }^{416}$ AVRITZER, L.; COSTA, S., Teoria Crítica, Democracia e Esfera Pública: Concepções e Usos na América Latina, p. 723.

${ }^{417}$ HABERMAS, J., The Inclusion of the Other, p. 126. 
mas aos coronéis locais, hoje substituídos ou transfigurados pelo mercado e pelos agentes de lobby que controlam as relações de governabilidade do governo ${ }^{418}$.

As noções de legitimidade dessa pesquisa são baseadas na necessidade de existência de estruturas básicas de justificação, bem como na responsividade do sistema político capaz de relacionar-se com o cidadão sem mediadores e contraria essa mercantilização das relações sociais e políticas que só afastam o representante do representado. É preciso registrar que a estrutura normativa constitucional brasileira está na contramão dessa ordem neoliberal simplificadora das interações intersubjetivas da sociedade que facilita as estruturas de dominação ${ }^{419}$.

A Constituição de 1988 privilegiou o debate e as construções em torno das ideias de descentralização e do "poder local", uma construção contrária à ideia de apropriação da estrutura política por algo que não fosse a participação do povo ${ }^{420}$. Por esse motivo, não faz sentido algum que a base de sustentação do governo governabilidade - coloque-se sobre acordos políticos interpartidários, sem qualquer respaldo e respeito pela opinião pública. Essa estrutura carece de justificação e é construída sobre o agir estratégico, não se traduzindo em reconhecimento dos sujeitos invisibilizados e ignorados no país. Na linha dos argumentos desse trabalho, ela carece de uma legitimidade que só pode ser reconquistada através do deslocamento das bases do governo para o povo com o incremento de participação popular.

Durante sua evolução nas décadas que se passaram, a participação democrática contribuiu para a formação de uma solidariedade cidadã capaz de ser fonte de legitimação da estrutura normativa. Trata-se da aquisição da qualidade de membro da comunidade democrática por sujeitos desrespeitados e ignorados por

\footnotetext{
${ }^{418}$ FONSECA, F., Democracia e participação no Brasil: descentralização e cidadania face ao capitalismo contemporâneo, p. 246.

${ }^{419}$ Wolfgang Streeck registra que "[...] nos dias de hoje nós não vemos líderes políticos em contato com suas sociedades - com movimentos sociais ou de classes. Nós vemos especialistas em relações públicas e seu poder de fala cuidadosamente moldado, desenhado para criar todos os tipos de ilusão de agência e impacto". Tradução livre. No original em inglês: "[...] in these days we are not seeing political leaders in touch with their societies - with social movements or classes. We are listening to PR specialists and their carefully crafted power-speak, designed to creat all sorts of illusions of agency and impact". CROUCH, C; PORTA, D. d.; STREECK, W., Democracy in neoliberalism?, p. 501.

${ }^{420}$ FONSECA, F., Democracia e participação no Brasil: descentralização e cidadania face ao capitalismo contemporâneo, p. 252.
} 
longos anos, agora, desejosos de participar ativamente do poder político ${ }^{421}$. Este item é a busca para uma alternativa que permita aos governos eleitos, ao mesmo tempo, livrar-se de acordos e de barganhas clientelistas e fisiológicas com outros partidos e aumentar a legitimidade de suas decisões, através de uma participação direta do povo não mediada pelo operador da representação. É a crença na "capacidade criativa daqueles que, de forma eficiente, dinamizam formas de ação coletiva, como os protestos por exemplo, no sentido de garantirem a sua efetiva inclusão, e das suas perspectivas, nos mecanismos que sustentam o bom funcionamento das instituições democráticas" ${ }^{422}$.

Não é mais possível confiar no modelo tradicional de pesos e contrapesos, ele é simplesmente insatisfatório do ponto de vista institucional, ao menos que haja participação direta. Veja que a relação entre cidadão e governo é mediada nos sistemas tradicionais e nos acordos feitos pelos partidos para governar, somente a participação do povo é capaz de alterar esse caráter decisório indireto ${ }^{423}$. A participação direta é a única busca por legitimidade incapaz de universalizar demandas, incapaz mesmo de conceber movimentos sociais unos, de uma só bandeira; até mesmo porque a própria formação dos movimentos sociais consiste em lutas por reconhecimento entre grupos e sujeitos humilhados que desejam tornar públicas suas demandas ${ }^{424}$.

Não há possibilidade de acordo de coordenação de ações, quando imposto do exterior, ele só acontece por meio de um acordo procedimental decisório, em razão das multiplicidades e pluralidades presentes no mundo da vida ${ }^{425}$. A mediação e a normalização impedem que essas diferenças sejam exercidas. É mais do que necessário reafirmar as práticas de autodeterminação dos cidadãos e não de seus representantes, é assim que deve ser a democracia e também a governabilidade, o poder constitucional não está nos representantes, tampouco há possibilidade de representação da soberania do povo ${ }^{426-427}$.

\footnotetext{
${ }^{421}$ HABERMAS, J., The Inclusion of the Other, p. 112.

${ }^{422}$ MATOS, A. R., "Eu participo, tu participas...nós protestamos": ações de protesto, democracia e participação em processos de decisão, p. 124.

${ }^{423}$ POGREBINSCHI, T., The Pragmatic Turn of Democracy in Latin America, p. 11.

${ }^{424}$ FRASER, N.; HONNETH, A., Redistribution or Recognition? A political-philosophical exchange, p. 120.

${ }^{425}$ HABERMAS, J., Pensamento Pós-Metafísico, p. 136.

${ }^{426} \mathrm{Id}$., The Inclusion of the Other, p. 250.
} 
As estruturas de justificação precisam estar ancoradas também na possibilidade dos grupos de se verem recompensados em relação à sua participação na política. Do contrário, os constantes esforços dos cidadãos enfraquecem sua crença na capacidade de influência do modelo político, até que não haja disposição para o enfrentamento ${ }^{428}$. Trata-se de uma desconsideração dos sujeitos como sujeitos políticos, o que ocorre a todo momento no Brasil. A maioria da população, pobre ou classe média, preta, do gênero feminino, simplesmente não se sente capaz em sua própria cidadania; é desacreditada a reconhecer-se como capaz de participar do processo decisório como sujeito igual, isso se deve à existência dos abismos sociais entre classes referendados através de negociações e acordos políticos que dispensam a participação cidadã.

Afinal, ausência de justiça social significa também ausência de cidadania, uma vez que as condições sociais básicas são necessárias para o exercício das capacidades do cidadão $^{429}$. A desigualdade em propriedades e em recursos financeiros é também uma desigualdade em recursos políticos, que possibilita uma cenário de dominação por aqueles poucos que possuem muito mais que os demais, reforçando a dominação e amplificando as desigualdades sociais ${ }^{430}$. O problema é quando essa dominação é racionalizada e apresentada como justificação da desigualdade pelas elites; porque ela acaba sendo internalizada da mesma forma pelo pobre que reduz suas expectativas normativas para tornar sua humilhação e miséria mais toleráveis ${ }^{431-432}$. A justificação dos acordos e negociações políticas com base na necessidade de uma governabilidade, nada

427 Habermas explica ainda outro problema da mediação que acontece através dos mecanismos reguladores do dinheiro e do poder: "A individualização social associa-se, segundo esta interpretação, a um processo pelo qual a integração social, em lugar de ser efectuada através de valores, de normas e processos que visam o entendimento, se efectua através de media reguladores tais como o dinheiro ou o poder e que entroncam nas preferências de actores individualizados que decidem de forma racional.” Id., Pensamento Pós-Metafísico, p. 233.

${ }^{428}$ MARTINS, P. G.; GONTIJO, L. A., Teoria do Reconhecimento e Economia Solidária: uma proposta de recomposição entre igualdade e solidariedade, p. 209.

${ }^{429}$ POGREBINSCHI, T., The Pragmatic Turn of Democracy in Latin America, p. 15.

${ }^{430}$ DAHL, R. A., Polyarchy: Participation and Opposition, p. 54-55.

${ }^{431}$ Ibidem, p. 101.

432 Apenas preciso registrar que, ao reforçar a ideia de que as experiências de humilhação e desrespeito são capazes de comprometer a formação identitária do sujeito a ponto de torna-lo dominado por seu algoz, retorno à dimensão intersubjetiva do reconhecimento e identifico alguns mecanismos de dominação presentes nos sistemas exclusivamente representativos. Essas duas constatações não significam que a dominação não possa ser rompida, pelo contrário, na mesma linha da teoria do reconhecimento, é através dessas experiências de humilhação que, em determinado momento, as demandas por reconhecimento encabeçam processos de luta que podem resultar numa melhora do reconhecimento. 
mais é do que a falsa justificação que permite ao sistema político exclusivamente representativo perpetuar-se inesgotavelmente, sem permitir abertura aos cidadãos na esfera pública.

Seguindo o posicionamento de Honneth, até mesmo injustiças distributivas devem ser compreendidas como formas institucionalizadas de relações de reconhecimento injustificáveis ${ }^{433}$, logo, é interessante trazer a separação entre reconhecimento e distribuição de Fraser que parece mais didática para a análise desse momento. Justamente, porque a divisão classista da sociedade está baseada em um problema de negação de paridade de participação pelos mecanismos econômicos institucionalizados. Ao mesmo tempo, reconhecer que há um problema de hierarquização é dizer que são padrões de valorações culturais desiguais que estão institucionalizados e impedem a paridade de participação nas interações sociais - nesse caso, as políticas ${ }^{434}$. A governabilidade baseada em acordos clientelistas e não no povo é evidência de que a negação de paridade de participação, seja pelos padrões econômicos ou culturais, está institucionalizada no sistema político. Este é um dos pilares excludentes da representação atual no Brasil que deve ser desconstruído para se falar em democracia, legitimidade e justificação.

Por isso, que a governabilidade em um sistema verdadeiramente democrático deve garantir renda, status e estima para todos os cidadãos, o que só pode ocorrer, se a base legitimadora do governo for sustentada pelo povo ${ }^{435}$. Porém, o movimento tem se mostrado no sentido inverso, onde os conflitos referentes ao status assumem um momento paradigmático de aumento da desigualdade econômica em razão de uma expansão animalesca do neoliberalismo ${ }^{436-437}$. A normatividade apresentada pelas competições ferozes e

\footnotetext{
433 FRASER, N.; HONNETH, A., Redistribution or Recognition? A political-philosophical exchange, p. 114.

${ }^{434}$ Ibidem, p. 49.

${ }^{435}$ DAHL, R. A., Polyarchy: Participation and Opposition, p. 77.

${ }^{436}$ FRASER, N.; HONNETH, A., op. cit., p. 92.

${ }^{437}$ Colin Crouch diz que o neoliberalismo precisa de "uma democracia 'domesticada' onde as forças opositoras raramente tem chance de obter o poder, onde há sempre comprometimentos políticos. Isso representa um regime em que as leis só mudam com divulgação prévia, onde há chance para consulta e posterior lobby antes que as regras sejam implementadas." Tradução livre. No original, em inglês: "a 'domesticated' democracy in which strongly oppositional forces very rarely get a chance to have power, where there are ways political compromises. That provides for a regime in which the law changes in ways that are announced in advance, where there is a chance
} 
excludentes desse novo modelo econômico não pode ser entendida como racionalmente justificável por todos, as institucionalidades propostas não contam com aceitação geral baseada em trocas de razões. Verifica-se que todos os pilares de eficácia de um sistema político - dos quais faz parte a governabilidade - estão afetados por uma noção de injustiça social ${ }^{438}$.

A reprodução de discursos estratégicos de normalização e de privilégio do saber técnico surge para assimilar e subordinar as culturas diferentes, em que a inclusão na lógica governamental vai representar renúncia à identidade dos sujeitos ou grupos ${ }^{439}$. Há sempre que relembrar que se está diante de um problema de justiça e poder, utilizando, no cenário real, os critérios de reciprocidade e generalidade para avaliar as estruturas de justificação que afetam, inclusive, a distribuição de bens e direitos de participação. Afinal, quem decide quem recebe bens e direitos? Essa pergunta é fundamental para analisar as relações de empoderamento, autonomia e dominação ${ }^{440}$.

Nesse sentido, pode-se visualizar o empoderamento de mulheres e pretos que ocorreu nos últimos anos, diante de políticas pensadas para reduzirem as assimetrias históricas, ainda que distante de solucionar os problemas sociais de justificação desses sujeitos. Imagine se essas políticas incluíssem considerá-los na equação da governabilidade parlamentar ${ }^{441}$ ? Ocorre que, ao mesmo tempo que é possível identificar um movimento emancipador no Brasil, há também um forte vetor dos mercados para garantir que a governabilidade considere apenas acordos e composições partidárias fiéis à influência que esses atores são capazes de exercer no ambiente político prático. Nas palavras de Francisco Fonseca:

Mas, paralelamente a esse movimento emancipador, alocado na superestrutura jurídico/política, a estrutura econômica do capitalismo contemporâneo atuava e atua cada vez mais no sentido inverso, isto é, volta-se à precarização e informalização das relações de trabalho, no contexto de robustas transformações da

for consultation and then lobbying before changes in rules are implemented." CROUCH, C.; PORTA, D. d.; STREECK, W. Democracy in neoliberalism?, p. 503.

${ }^{438}$ FRASER, N.; HONNETH, A., Redistribution or Recognition? A political-philosophical exchange, p. 130.

${ }^{439}$ Wolfgang Streeck registra que a defesa de que o povo não tem conhecimento técnico para lidar com as questões complexas deve ser vista com muito ceticismo, já que as lógicas oferecidas por operadores financeiros, por exemplo, nunca se tratam de uma matemática neutra, mas uma matemática constituída por relações de poder econômico. CROUCH, C.; PORTA, D. d.; STREECK, W.,op. cit., p. 501.

${ }^{440}$ FORST, R., The Right to Justification: elements of a constructivist theory of justice, p. 195.

${ }^{441}$ COSTA, S., Entangled Inequalities, State, and Social Policies in Contemporary Brazil, p. 10. 
maneira de produzir. Afinal, o capitalismo 'flexível', que discutiremos abaixo, necessita cada vez mais de menos trabalhadores, em todos os setores da economia, para auferir lucros crescentes. Daí as infindáveis teses do 'fim do emprego' ${ }^{442}$.

A governabilidade baseada em acordos herméticos à participação pública, juntamente com os cenários gritantes de desigualdade dão origem ao que Dahl chama de regimes hegemônicos, contrários à ideia de poliarquia que seria a perseguição de um modelo democrático. Nos regimes não hegemônicos poliarquias - devem haver grupos mais ou menos iguais, com menores diferenças de renda, status e bem estar. Não deixa de ser óbvio repetir que os recursos econômicos significam formas de influenciar e ter poder sobre os outros, o que se revela na estrutura da governabilidade atual; trata-se de uma forma desigual de exercício de poder ${ }^{443}$. Veja, por exemplo, que as grandes empresas e empreiteiras - agora envolvidas em escândalos de corrupção - fizeram largas doações de campanha para ambos os candidatos que chegaram ao segundo turno das eleições presidenciais de $2014^{444}$. Ou seja, o dinheiro é investido em lados antagônicos da disputa política para que a empresa seja capaz de exercer influência durante o mandato de qualquer um dos vencedores. Trata-se de uma lógica da gestão de interesses públicos que tem tudo por base, menos o interesse do povo, principalmente, se for considerar os menos favorecidos que sofrem com a ausência de reconhecimento na sociedade.

Porém o povo, o cidadão comum e o mundo da vida não podem ser esquecidos e nem controlado através da violência. É dessa forma que há uma profissionalização antiga da bipartição do modelo político dominador, em que há um modelo democrático para determinada parte da população - os mais ricos com capacidade de influenciar nas equações de governabilidade do jogo político - e um modelo hegemônico em relação ao restante da população. Historicamente tem sido possível perpetuar esse regime dual ${ }^{445}$. É praticamente inconcebível a

\footnotetext{
${ }^{442}$ FONSECA, F., Democracia e participação no Brasil: descentralização e cidadania face ao capitalismo contemporâneo, p. 248.

${ }^{443}$ DAHL, R. A., Polyarchy: Participation and Opposition., p. 81-82.

444 TERENZI, G.; AZEVEDO, R., Alvos da Lava Jato doaram R \$ 73 mi para Dilma e Aécio. As informações detalhadas encontram-se em TSE (Brasil)., Divulgação da prestação de contas Eleições 2014.

${ }^{445}$ DAHL, R. A., op. cit., p. 93-94.
} 
existência de uma democracia - poliarquia nas palavras originais do autor - em países de pluralismo cultural que perpetuam regimes duais ${ }^{446-447}$.

O modo de construção da governabilidade no Brasil, conforme foi apresentado no primeiro capítulo, não goza da confiança dos eleitores, é um dos grandes fatores responsáveis pelo afastamento dos representantes de seus representados. Isso porque ele exclui a possibilidade de comunicação, na hora da definição das condições e acordos constitutivos da governabilidade. Na mesma linha dos alertas de Dahl, é fácil registrar que a confiança mútua favorece os regimes poliárquicos, enquanto a desconfiança extrema favorece regimes hegemônicos. É assim porque um regime democrático precisa do estabelecimento da comunicação para o entendimento, o que se torna impossível se não há confiança entre os agentes de fala - no caso, de um lado, políticos formadores de alianças para governabilidade e do outro, o povo ${ }^{448}$.

É fácil ver que a comunicação exercida pelos agentes políticos não tem nenhuma intenção de agregar o povo ao processo decisório, ou deitar nele as bases necessárias para governar um país, usando o verdadeiro poder constituinte contra a oposição que deseje formar maiorias. As formas de comunicação entre Estado e cidadão se dão, quase sempre, de forma estratégica, através de propagandas e exposições unilaterais que não permitem a interação e crítica dos cidadãos, a quem é relegado o papel de "meros expectadores entediados da política"449. A utilização de qualquer meio de dominação para suprimir o diferente ou o pobre da política é incompatível com um regime democrático que necessita do conflito para se desenvolver ${ }^{450}$. As poliarquias - democracias - dependem de, pelo menos, informação, educação, comunicação e criação de ordens pluralísticas capazes de combater desigualdades, ao invés de estruturas sociais dominadoras ${ }^{451}$, tais como uma governabilidade baseada em acordos impopulares sedimentados sobre as lógicas de fins dos sistemas financeiro e burocrático e não na comunicação típica do mundo da vida de ações coordenadas.

${ }^{446}$ DAHL, R. A., Polyarchy: Participation and Opposition, p.113-116.

${ }^{447}$ Nos EUA, por exemplo, como era possível dizer haver uma democracia quando ainda haviam regras separatistas entre brancos e pretos? Havia uma democracia [poliarquia] para os brancos que se erguia sobre a dominação hegemônica dos pretos. Em: Ibidem, p. 29.

${ }^{448}$ Ibidem, p. 151-152.

${ }^{449}$ PERES, P. S., A barganha nas vísceras do modo brasileiro de governar, p. 6.

${ }^{450}$ DAHL, R. A., op. cit., p. 60-61.

${ }^{451}$ Ibidem, p. 74. 
Essa espécie de governabilidade é gatilho de uma crise moral comunicacional em que os sujeitos são desapontados - diante de contextos injustificáveis - em relação às expectativas normativas que colocavam sobre políticos eleitos. ${ }^{452}$ A representação, ainda que problemática, deveria cumprir sua função básica de representar as intenções daqueles que a elegeram. Porém, mesmo esquecendo todas as incongruências das normalizações que ocorrem dentro das lógicas representativas, os representantes, no Brasil e no mundo, ao buscarem proteger interesses dos grandes mercados e agentes financeiros, compondo uma governabilidade impenetrável aos desejos do povo, tornam-se completamente inadimplentes em relação à necessidade discursiva e responsiva que têm com seus eleitores; aumentam a injustificação do sistema exclusivamente representativo.

Também nesse sentido, deve haver uma inversão na lógica de constituição da governabilidade, a democracia precisa procurar caminhos capazes de justificarse em si mesma ${ }^{453}$, não como substância, mas como procedimento que privilegia o princípio da justificação e o agir comunicativo. É necessário democratizar o cotidiano da política em estreita comunicação com o mundo da vida e não com os sistemas financeiros e burocráticos. Numa governabilidade baseada na legitimação popular, utilizando-se de mecanismos de participação direta para determinar-se, o cidadão precisa ter a oportunidade de expressar suas preferências, dar significado para seus companheiros na sociedade e para o governo e de ter suas preferências levadas em consideração de maneira igual, perante a conduta do governo ${ }^{454}$.

Por isso o tema da governabilidade se tornou tão importante para os argumentos dessa pesquisa, a representação política não pode estar ancorada exclusivamente nos momentos eleitorais e nos espaços institucionais limitados de comunicação. É preciso que haja uma lógica de coordenação com o outro - o representado - e não pelo outro ${ }^{455}$. Não é mais possível que haja um entendimento de que o representante recebeu uma carta branca para negociar todas as questões ético-normativas que vão reger a sociedade, em nome do representado; o que

${ }^{452}$ HONNETH, A., The Struggle for Recognition: The Moral Grammar of Social Conflicts, p. 138. ${ }^{453}$ PERES, P. S., A barganha nas vísceras do modo brasileiro de governar, p. 5-7.

${ }^{454}$ DAHL, R. A., Polyarchy: Participation and Opposition, p. 2.

${ }^{455}$ POGREBINSCHI, T., Democracia Pragmática: Pressupostos de uma Teoria Normativamente Orientada, p. 666. 
parece acontecer no modelo atual de construção da governabilidade. Mesmo nos países, onde haja voto direto universal para eleição de representantes, se a possibilidade de participação não envolve ser ouvido em contestações e desejos, o déficit democrático está presente ${ }^{456}$.

A conclusão mais acertada é que o modelo liberal representativo e os padrões de estabelecimento da governabilidade tornam o cidadão indiferente ao espaço público discursivo e dão resposta às demandas individuais apenas daqueles que têm capacidade de figurar nas minorias dominantes ${ }^{457}$. Mais uma vez, é possível ver um individualismo democrático que torna as relações intersubjetivas Estado/cidadão e cidadão/cidadão imaturas, baseadas em padrões comodificados de consumo $^{458}$, ancoradas numa Carta Magna de igualdades que tem pouca ressonância nos padrões de justificação e numa real construção de paridade de participação $^{459}$.

Apesar da distância das abordagens teóricas de Rancière e da construção filosófica de Habermas, é possível retomar o ponto da perda das justificações metafísicas que impede as justificações tradicionais de consensos e acordos políticos. Não pretendo dizer que, no mundo tradicional, as lógicas de governabilidade baseadas em acordos interpartidários e estruturas econômicas (neo)liberais eram suficientemente justificáveis e aceitas por toda parte da população. Apenas é necessário estabelecer que a desconsideração do discurso e da necessidade de justificação fica mais gritante nas sociedades pós-metafísicas e plurais dos dias atuais.

Isso porque não é mais possível uma justificação de uma governabilidade baseada em uma ética metafísica ou uma filosofia moral tradicional que não possa ser aceita ou criticada por todos, isso só acontece através da inexistência do discurso no modelo atual de composição política. Não existe força moral ilocucionária no acordo "dos de cima”, de uma elite política capaz de decidir pelos outros sem que haja espaço para confrontação das razões decisórias

${ }^{456}$ DAHL, R. A., Polyarchy: Participation and Opposition, p. 5.

${ }^{457}$ RANCIÈRE, J., O ódio à democracia, p. 17.

458 Ibidem, p. 38-39.

${ }^{459}$ Rancière iria além da crítica que faço aqui e diria ainda: “A conclusão à qual chegamos assim é que a democracia é uma forma política de outra era que não pode convir à nossa, salvo à custa de sérias mudanças e, em particular, de um rebaixamento da utopia do poder do povo." Ibidem, p. 52. 
baseadas numa demanda pela participação no jogo discursivo da justificação ${ }^{460-}$ 461.

A perda da justificação metafísica demanda que as democracias sejam construídas sobre procedimentos decisórios amplificados que possam ser compreendidos e porosos a todos, em que ninguém pode reclamar mais autoridade do que o outro, o privilégio dos pontos de vista deve desaparecer ${ }^{462}$. Isso não se refere à possibilidade de um consenso substancial ético, mas a uma moral procedimental capaz de construir pontes de justiça e solidariedade, ainda que entre os eticamente diferentes ${ }^{463}$. No encontro discursivo com o outro, possível pelos meios conflituosos da participação direta, o eu é capaz de projetar seus interesses em seus interlocutores e ter os deles projetados sobre si, não se trata de uma transfiguração no outro ou de uma fala pelo outro, mas da capacidade de se reconhecer intersubjetivamente naquele que é diferente de si. É possível falar sobre uma integração social em contextos políticos de comunicação social, em que deve estar baseada a governabilidade, ao contrário da integração estratégica dos sistemas de mercado ${ }^{464}$.

A governabilidade, para ser constitutiva de um modelo democrático de decisão, deve estabelecer padrões discursivos de relação intersubjetiva entre representantes e representados - o que é possível através da utilização de mecanismos de participação direta. Os agentes devem ser capazes de compreender previamente como estão exercendo influência sobre os demais e de que forma sofrem influência nessa busca por entendimento ${ }^{465}$. A governabilidade deve assumir o papel mencionado de transcendência do momento eleitoral que era tido como único espaço onde o eleitor tinha a possibilidade de avaliar as alegações de validade dos representantes. $\mathrm{O}$ reconhecimento intersubjetivo parte desta pretensão de validade e aceitação da condição de sinceridade do locutor com o

${ }^{460}$ HABERMAS, J., The Inclusion of the Other, p. 11 e 22.

461 As citações que faço nos próximos parágrafos são para não correr o risco de utilizar argumentações dos autores sem a devida referência. Entretanto, é óbvio que os trechos referenciados nunca falaram em governabilidade, há uma interpretação da governabilidade enquanto normatividade institucional que deve ser analisada do ponto de vista da justificação da mesma forma que as normatividades mencionadas pelos autores citados.

${ }^{462}$ HABERMAS, J., The Inclusion of the Other, p. 23.

${ }^{463}$ Ibidem, p. 29.

${ }^{464}$ Ibidem, p. 159.

${ }^{465}$ Id., The Theory of Communicative Action: Reason and the rationalization of society. V. 1., p. 286. 
propósito de gerar confiança mútua e coordenação ${ }^{466}$. Isso não existe mais - ou nunca existiu - no momento eleitoral, porque a possível confiança que seria estabelecida é descontruída através de uma governabilidade construída sobre os acordos distantes da população.

Mesmo reconhecendo que o direito moral à justificação não significa o direito a uma vida boa, ele tem o direito de não ser dominado, de não sofrer abuso sob um Estado patriarcal e hegemônico ${ }^{467}$. Nos contextos de grande desigualdade social, essa preocupação deve consubstanciar-se em uma construção de processos decisórios políticos que se importem com o sofrimento e humilhação do outro, gerando situações de reconhecimento intersubjetivo que permitam o acesso/conhecimento da condição do outro através da linguagem ${ }^{468}$.

Para estar inserida num contexto de justificação, comunicação e reconhecimento, a governabilidade deve atender aos aspectos levantados por Forst no seguinte trecho:

Quando falamos de justiça social e política, falamos do [...] dever dos membros de determinado contexto social e político de estabelecer instituições baseadas em normas que possam ser legitimamente consideradas genérica e reciprocamente válidas e vinculantes ${ }^{469}$.

Para desconstruir esse padrão de governabilidade que gera dominação social, é preciso utilizar-se da amplificação de ambientes discursivos educacionais empoderadores dos sujeitos, capaz de dar-lhes autonomia enquanto participantes da sociedade e não como indivíduo desconexo de processos individuais. Essa associação coordenativa entre iguais deve realizar uma mudança no paradigma da governabilidade que permita a desconstrução das hierarquias presentes e uma descentralização do $\operatorname{poder}^{470}$.

O instituto da governabilidade precisa incorporar valores democráticos que afetem diretamente as práticas cotidianas, trazendo os cidadãos para a construção da legitimação decisória. Isso faz parte da ideia reconstrutiva das relações entre

\footnotetext{
466 HABERMAS, J., The Theory of Communicative Action: Reason and the rationalization of society. V. 1., p. 316 e 323.

${ }^{467}$ FORST, R., Justification and Critique: Towards a Critical Theory of Politics, p. 104.

${ }^{468}$ FASCIOLI, A., O Reconhecimento como Núcleo de Fundamentação da Normatividade: reflexões sobre a crítica de Honneth à ética do discurso habermasiana, p. 54.

${ }^{469}$ Tradução livre. FORST, R. op. cit., p. 113.

${ }^{470}$ MARTINS, P. G.; GONTIJO, L. A., Teoria do Reconhecimento e Economia Solidária: uma proposta de recomposição entre igualdade e solidariedade, p. 207 e 2015.
} 
Estado, instituições e sociedade, com base na concretização da soberania popular ${ }^{471}$. É a necessidade de uma democracia polissêmica: "não pode mais ser circunscrita à arena político-institucional, embora continue a contemplá-la" ${ }^{\$ 72}$. Não é mais possível pensar em uma esfera pública onde a comunicação seja subtraída pelo governo, ela precisa ser ressignificada para que atenda a uma noção republicana em que a formação de opiniões na polis não observe estruturas e processos mercadológicos, respeitando estruturas de justificação orientadas para o entendimento e comunicação. É uma vantagem da noção republicana radical que preserva a consciência radicalmente democrática da sociedade, através de uma coordenação comunicativa de $\operatorname{cidadãos}^{473}$.

Nesse processo, ainda que trate da complicada diferenciação entre esferas públicas e privadas, a articulação democrática habermasiana pressupõe a segurança das autonomias públicas e privadas dos sujeitos. Afinal, é mentirosa a garantia da possibilidade de falar em segurança dos direitos privados de sujeitos principalmente os sub-representados e não reconhecidos - sem que eles possam ser enfrentados e justificados em debates públicos. A autonomia privada depende de um exercício efetivo da autonomia pública enquanto cidadão e isso precisa ser considerado diante das alianças para a governabilidade ${ }^{474}$. Não é nada mais, nada menos, a defesa do mundo da vida contra as estruturas objetivantes, alienantes, moralizantes e estetizantes da cultura dos peritos científicos ${ }^{475}$; que seria o pensamento de que é possível compor um governo através de uma elite política pensante sem a participação popular. O que não passa de um discurso estratégico que tem como objetivo principal afastar o povo da polis.

Não é essa a verdadeira estrutura de uma democracia capaz de justificar-se aos olhos de todos os sujeitos da comunidade, principalmente, em sociedades desiguais onde há diferentes mundos da vida. É evidente que as elites não pretendem submeter-se aos critérios públicos de racionalização orientada para o entendimento, porque seria demasiadamente perigoso. Porém deve-se lembrar que

${ }^{471}$ AVRITZER, L.; COSTA, S., Teoria Crítica, Democracia e Esfera Pública: Concepções e Usos na América Latina, p. 704.

${ }^{472}$ FONSECA, F., Democracia e participação no Brasil: descentralização e cidadania face ao capitalismo contemporâneo, p. 251.

473. HABERMAS, J., The Inclusion of the Other, p. 240 e ss.

${ }^{474}$ Ibidem, p. 264.

${ }^{475}$ Id., Pensamento Pós-Metafísico, p. 44. 
"as decisões coletivas, especialmente aquelas que são problemáticas, são melhores tomadas através da conversa, em vez de coerção, incentivos baseados em dinheiro, de autoridade tradicionais ou pessoais" ${ }^{\prime 46}$, mesmo que isso seja visto como ingenuidade. Privilegiando as palavras de Habermas:

Só ao agir comunicativo se aplica que as limitações de uma linguagem partilhada a nível intersubjetivo levam os atores - no sentido de uma necessidade transcendental débil - a abandonarem o egocentrismo de uma orientação pautada pelo fim racional do êxito próprio e a submeterem-se aos critérios públicos da racionalidade do entendimento ${ }^{477}$.

Para que cesse o privilégio total do caráter técnico em detrimento do caráter participativo e da noção de uma governabilidade que protege os processos públicos de decisão da intrusão do cidadão, é preciso um sistema democrático que se qualifique pela ausência de hostilidade contra as formas de ação coletiva direta, com a capacidade de acolhê-las como um direito que obriga a abertura de mais espaços comunicativos e como legitimador das agendas políticas ${ }^{478}$.

Pode parecer uma espécie de populismo, mas não com a conotação negativa de que as correntes mais liberais tendem a atribuí- $10^{479}$. Trata-se de inverter o vetor de colonização do mundo da vida, no instituto da governabilidade, opondo-se a uma lógica de legitimação baseada nos partidos políticos enraizados em uma esfera pública, que precisa ser revitalizada em formas de autogoverno que derrotem a regulação burocrática e mercadológica dos padrões de governo atual $^{480}$.

A governabilidade só pode ser considerada democrática, se tiver como fiadora de legitimidade as manifestações diretas e disfuncionais do poder popular. O Estado é responsável por construir estruturas de justificação capazes de institucionalizar a participação ativa do cidadão em seus procedimentos decisórios, seja através de mecanismos diretos de participação e diálogo, como audiências públicas, referendos e plebiscitos ou através da capacidade de

${ }^{476}$ WARREN, M. E., Deliberative Democracy and the Corruption of Speech, p. 5.

${ }^{477}$ HABERMAS, J., Pensamento Pós-Metafísico, p. 95.

${ }^{478}$ MATOS, A. R., "Eu participo, tu participas...nós protestamos": ações de protesto, democracia e participação em processos de decisão, p. 123.

479 "Populismo é o nome cômodo com que se dissimula a contradição entre legitimidade popular e científica, a dificuldade do governo da ciência para aceitar as manifestações da democracia e mesmo a forma mista do sistema representativo. Esse nome mascara e ao mesmo tempo revela a grande aspiração da oligarquia: governar sem povo, isto é, sem divisão do povo; governar sem política." RANCIÈRE, J., O ódio à democracia, p. 102.

${ }^{480}$ HABERMAS, J., The Inclusion of the Other, p. 247. 
interpretação e absorção das manifestações populares em protestos e ruas, afinal, tudo isso pode ser visto como espaços de trocas de razão, ou seja, espaços de justificação $0^{481}$.

As manifestações, protestos e todas outras formas de participação popular devem ser os espaços para dar voz e visibilidade àqueles que não conseguem se fazer ouvir e são invisibilizados, em um cenário de desigualdade social e de ausência de reconhecimento ${ }^{482}$. Mesmo sem saber a forma como instrumentalizar esse ponto, arrisco-me a dizer - incorporando um critério de Forst - que para conceber uma governabilidade efetivamente democrática, é preciso que os sujeitos em risco de sofrer desvantagens possuam um direito de veto institucional ${ }^{483}$. No Brasil, infelizmente, só os privilegiados têm direito de veto, assim como em todo mundo, as camadas historicamente excluídas não fazem parte do processo decisório político ${ }^{484}$

Encerro este item, para em seguida desenvolver com exatidão o que entendo por institucionalização do discurso, com menção a dois momentos em que o governo tentou, mas foi incapaz de capitalizar a participação direta como base para a governabilidade. O primeiro desinstitucionalizado, caótico das ruas e, o segundo, através da própria ação do governo de institucionalizar a participação social através do Decreto Presidencial da PNPS, sustado por Decreto Legislativo.

Foi clara a incapacidade do governo em compreender a massa que surgiu nas ruas em 2013 sem “"organicidade', nem 'linha', nem 'lideranças"”485. Parecia ser a nova formação do poder constituinte capaz de se manifestar politicamente. Diante da negação pelos outros poderes da sugestão de plebiscito para uma constituinte exclusiva, as tentativas de aproximação do governo com o povo "não vingaram". Vê-se que o governo foi incapaz de perceber nas manifestações essas novas formas de resistência e ação política, que inspiram diferentes formas de

\footnotetext{
${ }^{481}$ Discordando da abordagem de Amy Allen, Rainer Forst entende que os meios utilizados pelas ruas e pelos movimentos sociais são utilizados de forma a desmascarar a falta de razão do outro lado, o que não significa que, por utilizarem determinadas práticas, não exista uma orientação racional sobre o ato. ALLEN, A.; FORST, R.; HAUGAARD, M., Power and Reason, Justice and Domination: a conversation, p. 27.

${ }^{482}$ MATOS, A. R., "Eu participo, tu participas...nós protestamos": ações de protesto, democracia e participação em processos de decisão, p. 123.

${ }^{483}$ FORST, R., Justification and Critique: Towards a Critical Theory of Politics, p. 102.

${ }^{484}$ HABERMAS, J., Paradigms of Law, p. 21 e 23.

485 PILATTI, A.; NEGRI, A.; COCCO, G., Levante da Multidão.
} 
liberdades e participação. E não aquelas que estão dentro das caixas e dos protocolos pensados pelos partidos políticos estabelecidos, mesmo os ditos de esquerda, que, por diversas vezes, tentaram pautar um movimento impassível de determinação vertical, como deve ser toda a sociedade. A partir daí, a relação entre governo e povo só corre ladeira abaixo, porque a falta de sucesso, na tentativa de pautar o movimento, fez com que o governo optasse pela recuada das propostas reformistas - constituinte exclusiva, por exemplo -, voltando-se para sustentação de discussões abstratas que nada resolvem. E possibilitando a apropriação das ruas pelos setores conservadores que retornaram a partir de 2015 . Um trecho de Pilatti evidencia esse argumento de incapacidade de os atores tradicionais de representação se apropriarem das formas de participação e luta direta, da direita retrógrada à esquerda mais progressista em 2013:

Pela resistência dos partidos aliados ao Governo, que nada querem mudar nas regras que lhe garantem postos governamentais e burocráticos, apostam que o desgaste resultante do movimento incidirá apenas sobre o PT, e esperam que "a coisa passe" Last but not least, pela oposição de direita demofóbica, que viu na proposta presidencial [constituinte exclusiva] uma tentativa de "venezualização" do processo, e deu ampla vazão à sua paranoia através da grande mídia. Direita e mídia não querem reduzir a corrupção da política, mas apenas usá-la, como de hábito, para reproduzir seu poder antidemocrático. Saudosa das formas institucionais do liberalismo oligárquico, elas buscam amplificar o duplo mecanismo de corrupção da democracia: a concentração perversa de poder econômico e a inversão da relação entre poder constituído (os representantes) e poder constituinte (o "demos") ${ }^{486}$.

Já a PNPS, sustada pelo poder legislativo e, de certa forma, abandonada pelo executivo que não pareceu implementar esforços para sua manutenção, estaria no caminho defendido neste item: o de ressignificar a governabilidade para uma possibilidade de participação popular. A simples leitura do Decreto da PNPS já demonstra uma busca pela amplificação da troca de experiências ${ }^{487}$, através do diálogo, entre a sociedade civil e a Administração Pública Federal. Nada mais é do que o reconhecimento da necessidade de buscar legitimação para a atuação administrativa. Infelizmente, esses dois momentos resultaram em muito pouco

486 Veja: "Os partidos os tratam como a massa e querem pautar, organizar, disciplinar e dar a palavra de ordem. Esses meninos não aceitam isso, felizmente, pois não referendam nada que não venha de baixo, de uma maneira horizontal". PILATTI, A.; COCCO, G., Quem teme o poder constituinte?

487 Fala-se na ideia de consensualidade administrativa enquanto novo paradigma do Direito Administrativo, representado pela necessidade/possibilidade da administração pública buscar procedimentos de horizontalização em relação aos particulares. Para melhores explicações ver OLIVEIRA, G. J., A Administração Consensual como a Nova Face de Administração Pública no Século XXI: Fundamentos Dogmáticos, Formas de Expressão e Instrumentos de Ação. 
avanço democrático para o sistema representativo. Alguns passos foram dados, mas ainda é preciso falar em necessidade de institucionalização do discurso através dos mecanismos de participação direta na democracia.

\section{3. \\ A institucionalização do Discurso através da Participação direta e o Modelo Democrático Reconstrutivista}

Este é o último item do trabalho que apresentei até o momento. A maior parte da ideia que pretendia já foi exposta, no que se refere: ao cenário brasileiro e ao estado da arte da democracia representativa, às teorias normativas que são possíveis articular para tratar da questão e aos caminhos que podem ser utilizados para fazer com que a democracia incorpore mecanismos capazes de satisfazer o princípio da justificação com base em encontros discursivos orientados para o entendimento. Agora, resta dizer como a incorporação dos mecanismos/formas de participação/manifestação direta nos processos públicos decisórios representa a própria institucionalização do discurso. Apesar do ponto já ter sido tocado, este item pretende esclarecer o motivo da escolha de um modelo misto entre representação e participação direta, reafirmar as noções democráticas que norteiam os caminhos apresentados e esclarecer por que defender a institucionalização da participação direta, o que isso significa e quais os caminhos e consequências que podem advir desse modelo democrático reconstrutivista misto.

$\mathrm{Na}$ base dos caminhos reconstrutivistas propostos está a ideia de que a representação não é um mal em si mesma, seria impossível falar em política e participação sem falar em representação. Na verdade, há uma valorização da crise em que a representação se encontra que confunde os problemas parasitários dessa forma de política - devido às suas limitações em um mundo plural - com a necessidade de expurgar da política o operador representativo. Essa falsa dicotomia entre democracia representativa e democracia participativa deve ser 
superada com uma análise mais profunda dos problemas do instituto da representação ${ }^{488-489,}$ o que se tentou fazer durante todo o trabalho.

É justamente na compreensão de uma democracia como mediadora entre Estado e sociedade civil que se procura superar esse falso dualismo, trata-se de uma desconstrução do antagonismo entre Estado moderno e aproximação dos cidadãos. Fala-se de uma ressignificação do modelo representativo para que se possa incorporar princípios participativos e deliberativos, amplificar a ideia de representação de atores sociais, levando em consideração opiniões não majoritárias, e redefinir a própria noção de delegação que constitui a legitimação da representação ${ }^{490}$. Não há nenhuma ameaça ao modelo representativo, como pensou o Congresso Brasileiro, ao editar o Decreto Legislativo sustando os efeitos da PNPS. Até mesmo porque, o oposto da representação é a não representação e não há nenhuma possibilidade de haver modelo político decisório sem representação de vontades, por mais direto que seja. Propõe-se trabalhar no próprio interior da democracia representativa ${ }^{491}$.

Já é incerto dizer se há, ou se havia uma transformação pragmática ocorrendo na América Latina dentro da própria democracia representativa. Thamy Progrebinschi chamou isso de virada pragmática que pode ressignificar a democracia, tornando-a mais legítima através da participação ${ }^{492}$. É a simples possibilidade de tornar a democracia representativa mais representativa, constituindo-se de processos e arranjos participativos e deliberativos ${ }^{493}$.

Antes de continuar, é necessário abrir um momento de ressalva ao pensamento de Thamy Pogrebinschi e à possibilidade/necessidade de encarar representação como algo positivamente transformável em favor de uma

\footnotetext{
488 POGREBINSCHI, T., Democracia Pragmática: Pressupostos de uma Teoria Normativamente Orientada, p. 658-959. É importante registrar que Thamy faz uma dura crítica às teorias normativas nesse ponto, registrando que elas se inclinam para essa tendência de mal entendimento dicotômico. Não acredito que as abordagens de Habermas ou Forst ofereçam qualquer limitação à aproveitar-se da noção de representação nesse ponto.

${ }^{489}$ Ao longo do trabalho tentei sempre registrar que os problemas levantados relacionavam-se a modelos exclusivamente representativos para registrar que era necessário aproveitar esse operador dentro da política.

${ }^{490}$ POGREBINSCHI, T., op. cit., p. 660-661.

${ }^{491}$ Ibidem, p. 681 e 686.

492 Id., The Pragmatic Turn of Democracy in Latin America. Friedrich, p. 4 e 7.

${ }^{493}$ Id., Democracia Pragmática: Pressupostos de uma Teoria Normativamente Orientada, p. 668.
} 
democracia mais democrática. Não há discordância nesse ponto, desde que a análise profunda da representação leve em consideração os problemas parasitários incorporados pelo operador da representação - muitos deles já citados ao longo do trabalho - num combate que pode indicar os caminhos pelos quais a participação deve tentar construir uma nova legitimação do sistema político.

Um dos problemas parasitários do operador da representação que evitei abordar, até agora, é a possibilidade de construção de acordos e consensos normalizadores - ponto muito criticado na teoria habermasiana, com o qual vou tentar lidar com um olhar extremamente positivo, que pode beirar certa ingenuidade, mas é necessário para permanecer na linha dos argumentos que desenvolvi. Apesar disso, não me furto de iniciar o ponto com as duras críticas à ideia de consenso levantadas por Rancière e Mouffe.

No modelo democrático atual, tenta-se privilegiar a ideia de consenso, refutando as duras marcas conflituosas de uma sociedade desigual, plural e eticamente divergente. Retiram-se as paixões das questões que devem ser tratadas dentro de uma sociedade, buscando uma resposta tecnicamente construída por representantes supostamente qualificados ${ }^{494}$. A realidade deveria caminhar no sentido contrário, de forma que a necessidade de enfrentar a complexidade oferecida pelo pluralismo faria cogente abrir mão da possibilidade de consenso racional substancial ${ }^{495}$.

Criticando a abordagem habermasiana, Mouffe diz que a ênfase na teoria do consenso com a rejeição da possibilidade do confronto é o que torna o cidadão apático e descrente da participação política. Esse tipo de consenso não pode existir, até mesmo porque ele sempre é utilizado para algum tipo de pacificação das estruturas hegemônicas de dominação, resultando em algum tipo de exclusão ${ }^{496}$. É bem verdade que a história mundial de decadência do sistema soviético e do enfraquecimento dos movimentos de lutas sociais emancipatórias contribuíram para a construção dessa criticada "visão consensual contida na lógica do sistema oligárquico". É a ilimitação do poder da riqueza que oferece apenas

\footnotetext{
${ }^{494}$ RANCIÈRE, J., O ódio à democracia, p. 96.

${ }^{495}$ MOUFFE, C., Deliberative Democracy or Agonistic Pluralism, p. 12.

${ }^{496}$ Ibidem, p. 16-17.
} 
um realidade e uma resposta adaptada, independentes do problema que se oferece $^{497}$, um consenso normativo quase metafísico impede diferenciações nas lutas políticas do mundo de hoje. Por exemplo, as eleições, em modelos exclusivamente representativos, permitem e asseguram a reprodução dos mesmos partidos e políticos dominantes, ainda que a urna não seja fraudada, mas por “escolha" dos representados ${ }^{498}$.

$\mathrm{Na}$ ideia da visão mais positiva de Habermas, concordo com as críticas de Rancière e Mouffe, entendendo que são aplicáveis aos modelos exclusivamente representativos dos dias de hoje. Porém, a concordância com esse ponto só é possível entendendo que o consenso criticado é aquele acordo substantivo em relação às normas da sociedade, não sendo mais possível em uma sociedade pósmetafísica, tendo por base uma esfera pública burguesa que pressupunha a ausência de presença das bagagens éticas nos processos deliberativos ${ }^{499}$. Essa perspectiva é fundamental para compreender a forma de avançar na defesa de um modelo institucionalista agregando as críticas dos democratas radicais.

Habermas precisa ancorar-se na possibilidade de estabelecimento de comunicações linguísticas que viabilizem acordos relativos a procedimentos decisórios capazes de conferir legitimidade às decisões em determinada sociedade. Ainda que não seja possível falar num acordo substantivo em relação a boa vida ou ao bem comum ${ }^{500}$. Trata-se de explicar como, de alguma forma nesse caso através da comunicação - é possível fazer com que a sociedade caminhe com determinadas escolhas em âmbito comunitário ${ }^{501}$. Não parece possível conceber um sistema político, ainda que se reconheça a permanência incessante do conflito, sem conceber a necessidade de tomada de decisões grupais que, eventualmente, desagradarão determinada concepção ética de vida. Mas que se explicam e se legitimam através do processo de argumentação enquanto procedimento decisório. Para isso, é preciso substituir o bem maior metafísico por

\footnotetext{
${ }^{497}$ RANCIÈRE, J., O ódio à democracia, p. 98.

498 Ibidem, p. 94.

499 FRASER, N., Rethinking the Public Sphere: A Contribution to the Critique of Actually Existing Democracy, p. 63.

${ }^{500}$ HABERMAS, J., The Inclusion of the Other, p. 40.

${ }^{501}$ A comunicação, mesmo entre diferentes padrões éticos e culturais, por mais difícil que possa ser, só será certamente impossível quando se imagine a possibilidade de abolir qualquer tipo de diferença do espaço de troca de razões. FRASER, N., op. cit., p. 69.
} 
uma perspectiva imanente de deliberação ${ }^{502}$. É justamente a noção de que um consenso de cultura homogênea não é necessário em uma formação democrática para que seja possível, entre estranhos, um acordo racional - não substantivo. Isso se estabelece sobre os procedimentos democráticos legitimadores baseados na comunicação que precisam existir para construir minimamente pontes de integração social ${ }^{503}$.

Foram essas ideias de consenso substancial e de resposta única possível que fizeram o modelo exclusivamente representativo se afastar do cidadão e deslocar a polis para perto do governo e longe do mundo da vida. A administração acaba se tornando responsável por si mesma com a capacidade de manipular os procedimentos públicos eleitorais, não havendo nenhum componente comunicacional nesse movimento ${ }^{504}$. Ainda hoje, trata-se de um Estado patriarcal $^{505}$ e intervencionista que desloca os procedimentos de legitimação para o interior do mundo político comodificado e burocratizado não afeito às estruturas comunicacionais do mundo da vida ${ }^{506}$.

São processos históricos já identificados que modernizaram os critérios de subordinação de classes e sujeitos. A diferenciação dos mercados que atua como núcleo das concepções econômicas que transformam as relações de interações sociais em relações de consumo, reguladas por lógicas estratégicas, individualistas e não por uma ação orientada para o entendimento. É a instrumentalização da diferença em favor da lógica de maximização de lucros do mercado gerando, necessariamente, estruturas de exclusão do diferente $\mathrm{e}^{507}$.

Trata-se da forma atual de supressão das oposições e dos ideais de participação que pode não mais envolver meios violentos de coerção, mas utiliza-

${ }^{502}$ HABERMAS, J., The Inclusion of the Other, p. 37 e 41.

${ }^{503}$ Ibidem, p. 137-138.

${ }^{504}$ Id., Soberania Popular como Procedimento: um conceito normativo de espaço público, p. 108.

${ }^{505}$ Mesmo os estados de bem-estar social massificados fazem com que a política troque padrões de publicização por publicidade - relações públicas -, meios de comunicação em massa e outras formas de moldar e manipular a opinião pública. É a prevalência do agir estratégico. FRASER, N. Rethinking the Public Sphere: A Contribution to the Critique of Actually Existing Democracy, p. 59.

${ }^{506}$ HABERMAS, J., Soberania Popular como Procedimento: um conceito normativo de espaço público, p. 108.

507 FRASER, N.; HONNETH, A., Redistribution or Recognition? A political-philosophical exchange, p.57-58. 
se de sanções socioeconômicas, controle de recursos, de meios de comunicação e processos de educação e socialização política. A dominação política garante a forma estratificada da sociedade, em que uma classe controla todas as outras de forma hegemônica. O resultado dessas sociedades estratificadas é o desenvolvimento de valores culturais desiguais, resultando na ampliação de pressões marginalizadoras das demandas dos grupos subalternos, na esfera pública $^{508}$. É através dos recursos financeiros que se formam as divisões de quem pode e quem não pode influenciar os outros. O resultado é uma forma desigual do exercício do poder que acaba descambando para dominação ${ }^{509}$.

Fechando as necessárias ressalvas ao modelo representativo, é preciso estabelecer porque a participação direta tem a capacidade de aumentar a legitimidade do sistema político. A primeira razão óbvia é que ela é mais propensa a gerar maior inclusão do outro, do diferente, significando dizer que os processos decisórios devem ser espaços de uma comunidade aberta a todos, mesmo que esses todos desejem permanecer como estranhos ${ }^{510}$. Porém, a maior evidência que se pode apresentar em favor dos mecanismos de participação direta é a defesa estabelecida pela abordagem da democracia pragmática. Trata-se de uma perspectiva que procura abrir a teoria para a informação da empiria, submetendose aos resultados possíveis que as experimentações de novas formas de participação possam atingir nos cenários legitimadores da representação. É a defesa de que a representação política não pode encontrar limites nos mecanismos eleitorais, tampouco pode basear-se exclusivamente em regras de maioria. Significa defender a possibilidade de "abertura para experimentar modos de aferição de accountability da representação diferentes da regra da maioria, e mecanismos de legitimação que transcendam a ambos [...]" "511. É uma chamada ao empoderamento do sujeito comum, por meio da institucionalização de práticas cotidianas discursivas como posicionamento político ${ }^{512-513}$.

\footnotetext{
${ }^{508}$ FRASER, N., Rethinking the Public Sphere: A Contribution to the Critique of Actually Existing Democracy, p. 62-64.

${ }^{509}$ DAHL, R. A., Polyarchy: Participation and Opposition, p. 48-49 e 82.

${ }^{510}$ HABERMAS, J., The Inclusion of the Other, p. xxxvi.

${ }^{511}$ POGREBINSCHI, T., Democracia Pragmática: Pressupostos de uma Teoria Normativamente Orientada, p. 685.

${ }^{512}$ Ibidem, p. 677.
} 
No Brasil, há ainda uma instigação para a incorporação cada vez maior da participação direta dentro do modelo institucional, justamente pelo sucesso das experimentações já executadas. Um sucesso que repercute na possibilidade de minorias transformarem-se em maiorias em fóruns de participação direta, de incentivar decisões parlamentares com o objetivo de incorporar novos grupos eleitorais, mas, sobretudo, como forma de mediação entre Estado e sociedade civil, paralela às eleições dos representantes ${ }^{514}$. Um sucesso que se comprova pela necessidade de amplificação institucional do reconhecimento da participação direta, para interferências em áreas onde nunca teve acesso - como explicado no primeiro capítulo - e para superação da perspectiva monista que não incorpora, institucionalmente, as mobilizações e protestos de rua ${ }^{515}$.

A participação direta é a forma pela qual o procedimento democrático pode se contrapor ao jogo do uno defendido pela representação, pondo em questão novas formas de subjetivação da vida pública ${ }^{516}$. Trata-se da possibilidade de exercer o poder comunicativo como assédio ${ }^{517}$, sobrepondo-se aos processos decisórios regulados pelo agir estratégico com os quais o poder administrativo dominador lida apenas, instrumentalmente, sem nenhuma intenção de se fazer entender ${ }^{518}$. Quando institucionalizada, a participação direta, com sua característica comunicacional, amplifica-se com a possibilidade de conexão entre mundo da vida e sistema ${ }^{519}$. É a oportunidade de colocar Estado e cidadão frente a frente, tornando viável não só uma ideia de validade sobre as locuções das partes, mas de compreensão da própria intenção do agente que é necessária para o real entendimento 520 .

\footnotetext{
${ }^{513}$ Novas formas de subjetividade são necessárias para ir contra a individualidade egoísta imposta há séculos. FOUCAULT, M., The Subject and Power, p. 336.

${ }^{514}$ POGREBINSCHI, T., Democracia Pragmática: Pressupostos de uma Teoria Normativamente Orientada, p. 675-676.

${ }^{515}$ AVRITZER, L., Impasses da democracia no Brasil, p. 14.

${ }^{516}$ RANCIÈRE, J., O ódio à democracia, p. 81.

517 A espontaneidade e a heterogeneidade são exemplos de características da "guerra civil da linguagem" e da linguagem da política. BENHABIB, S., Democracy and Difference: Reflections on the Metapolitics of Lyotard and Derrida, p. 7.

${ }^{518}$ HABERMAS, J., Soberania Popular como Procedimento: um conceito normativo de espaço público, p. 111.

${ }^{519}$ Id., The Theory of Communicative Action: Reason and the rationalization of society. V. 1., p. xi.

${ }^{520}$ Ibidem, p. 274-275.
} 
A própria Constituição de 1988, apesar dos ataques que vem sofrendo constantemente, representa uma espécie de estancamento do déficit democrático expressão habermasiana ${ }^{521}$ - existente num Brasil tão desigual. Apesar de não ser possível adotar uma visão formalista e crer que a Constituição está implementada totalmente na vida real, é possível partir de suas instigações para reforçar essa ideia de uma maior institucionalidade da participação direta. "As palavras-chave que sintetizam a Constituição, no espírito de uma verdadeira (re)fundação da República, são descentralização; participação popular; incorporação na vida política das associações civis; revalorização da ação política; e cidadania" ${ }^{\text {"522 }}$. Revela uma forma de eliminar a discriminação, ou ausência de reconhecimento, através de um processo de inclusão política sensível aos conteúdos culturais e éticos dos sujeitos e grupos presentes, em uma mesma sociedade ${ }^{523}$.

A lição de uma Constituição com valores descentralizadores e preocupados com a participação direta, sem uma efetiva criação de uma cultura de participação e sem a quebra das lógicas de dominações sociais existentes na sociedade, é a evidência da necessidade de que não é possível defender uma instituicionalização meramente procedimental, sem qualquer preocupação substancial. Mouffe, dessa vez sem razão, critica a teoria habermasiana por fazer a separação estrita entre procedimento e substância e por esquecer que procedimento sempre envolve uma comprometimento ético que não pode ser tido como neutro ${ }^{524}$. Mouffe parece falar da situação ideal de fala de Habermas, que não passa do modelo ideal hipotético do autor, ou estar analisando a escolha habermasiana de um consenso linguístico preliminar para possibilitar a comunicação. Porém, ao determinar que sua democracia procedimental é composta pelo binômio soberania popular e direitos humanos ${ }^{525}$, Habermas inclui substância em seu modelo procedimental.

De qualquer forma, as escolhas normativas feitas, ao longo dessa pesquisa, não podem ser acusadas de retirar a substância do procedimentalismo que se sugere a partir da institucionalização dos mecanismos de participação direta,

${ }^{521}$ HABERMAS, J., The Inclusion of the Other, p. 157.

${ }^{522}$ FONSECA, F., Democracia e participação no Brasil: descentralização e cidadania face ao capitalismo contemporâneo, p. 247-248.

${ }^{523}$ HABERMAS, J., op. cit., p. 145.

${ }^{524}$ MOUFFE, C., Deliberative Democracy or Agonistic Pluralism, p. 12.

${ }^{525}$ HABERMAS, J., Direito e Democracia: entre faticidade e validade, V. I., p. 146. 
mesmo que Mouffe estivesse certa sobre Habermas. Também não há dentro dessa noção reconstrutivista - próxima dos modelos deliberativos - o que Mouffe acusa como a retirada do poder da esfera pública para a realização de consensos suprimindo o antagonismo e o pluralismo. Concorda-se inclusive que o poder é constitutivo das relações sociais e necessário para compreender os valores democráticos ${ }^{526}$. Isso ficou claro, ao longo de todo trabalho, mas principalmente, nas explicações relacionadas ao princípio da justificação que se mostra como método preocupado com a institucionalização de mecanismos capazes de resguardar o caráter democrático e inclusivo do sistema e como Forst entende que as relações intersubjetivas são também relações de poder, através da troca de razões $^{527}$.

O princípio da justificação está recheado de critérios normativos substanciais tais como a reciprocidade e a generalidade, ou ainda critérios de reconhecimento intersubjetivo de tolerância como respeito. Todos eles podem assumir um papel de justiça dentro do procedimento deliberativo proposto, mas não perdem a substância normativa moral que carregam, afinal, há um tipo de respeito moral incondicionado na teoria da justificação ${ }^{528}$. É somente através de um princípio básico de justificação que se podem estabelecer liberdades e normatividades para os procedimentos democráticos, numa ideia de justiça política $^{529}$. Mesmo diante da necessidade de discordância, é claro que não pode haver dúvida sobre a necessidade de justificação ou de critérios de reciprocidade e generalidade. É o próprio componente normativo da justificação e da tolerância que assume um forma epistemológica de instrumentalização da razão, mesmo sem oferecer uma resposta sobre a vida boa ${ }^{530}$.

Torna-se necessário abordar mais uma diferenciação de Forst em sua teoria de justiça, a noção de justiça fundamental pode ser mínima e máxima. Ao pensar na aplicação do princípio da justificação, Forst visualiza a necessidade de

\footnotetext{
${ }^{526}$ MOUFFE, C., Deliberative Democracy or Agonistic Pluralism, p. 13-14.

527 Vide item 2.2 supra.

${ }^{528}$ FORST, R., Justification and Critique: Towards a Critical Theory of Politics, p. 145-146. Ou ainda, falando da tolerância como respeito “(...) nem a autoridade política nem a maioria dos cidadãos têm o direito de moldar as instituições básicas do Estado com base em suas concepções éticas do bem, uma vez que essas concepções possam ser criticadas por outros cidadãos como interessadas e particularistas." Id., Os limites da tolerância, p. 21.

${ }^{529}$ Id., The Right to Justification: elements of a constructivist theory of justice, p. 196.

${ }^{530}$ Id., Justification and Critique: Towards a Critical Theory of Politics, p. 142.
} 
formações de estruturas de justificação que podem ser básicas ou completas. É a possibilidade de colocar como parâmetro a justificação para construir procedimentos democráticos discursivos ${ }^{531}$. Nas palavras de Forst:

Justiça fundamental se expressa de forma paradoxal, é uma forma procedimental de justiça com implicações substantivas: utiliza-se de um direito moral à justificação, reivindica uma estrutura básica de justificação na qual os indivíduos têm a possibilidade real de genérica e reciprocamente determinar as instituições relevantes, notadamente, em relação à produção de bens e sua distribuição. Justiça fundamental garante a todos os cidadãos um status efetivo de 'iguais', enquanto cidadãos com real possibilidade de participação e influência. Há uma violação da justiça fundamental quando o poder básico de justificação é distribuído de maneira desigual dentro das instituições mais importantes. ${ }^{532}$

Não me parece que o pretendido por Forst em seu trabalho e o que eu pretendo nessa pesquisa seja diferente da ideia de deixar viver a contestação democrática, como defende a democracia agonística ${ }^{533}$. A discordância com Mouffe está na possibilidade de que haja uma racionalidade justificadora capaz de lidar com as diferenças éticas, mas não me parece outra coisa, quando a mesma menciona formas democráticas de individualidade e subjetividade. Como diz a própria autora, é preciso constituir cidadãos democráticos, isso só é possível através "da multiplicação de instituições, discursos e formas de vida que permitam

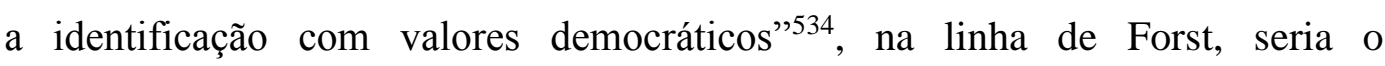
desenvolvimento de estruturas de justificação.

A defesa desse modelo reconstrutivista é baseada na possibilidade de participação que significa falar nos espaços de contestação e ser ouvido, como Dahl entende, uma ideia de contestação e inclusão na vida institucional dos processos decisórios ${ }^{535}$. A razão crítica revela não apenas as questões políticas, trata de relações e estruturas sociais que possam fazer a participação política

${ }^{531}$ FORST, R., The Right to Justification: elements of a constructivist theory of justice, p. 196.

532 Tradução livre. No original, em inglês: "Fundamental justice is thus expressed in a seemingly paradoxical way, a substantive implication of procedural justice: using a moral right to justification, a basic structure is argued for in which individuals have real possibilities for reciprocally and generally determining the relevant institutions themselves, namely, in relation to the production of goods and to their distribution. Fundamental justice ensures all citizens an effective status 'as equal', as citizens with real possibilities for participation and influence. A violation of fundamental justice is committed when the basic justificatory power is unequally distributed within the most important institutions." Ibidem, p. 197.

${ }^{533}$ MOUFFE, C., Deliberative Democracy or Agonistic Pluralism, p. 17.

${ }^{534}$ Tradução livre. No original, em inglês: "[...] by multiplying the institutions, the discourses, the forms of life that foster identification with democratic values". Ibidem, p. 10-11.

${ }^{535}$ DAHL, R. A., Polyarchy: Participation and Opposition, p. 4. 
possível ou não, são vários contextos de justificação em disputa ${ }^{536}$. A possibilidade de estabelecimento de relações de poder depende de que os participantes sigam o caminho habermasiano de estarem abertos aos significados e propostas dos outros ${ }^{537}$.

Rainer recupera Fraser não para concordar que a paridade de participação seja o próprio objetivo de justiça, mas para entendê-la como instrumento de perseguição de uma posição política e social de igual para todos os cidadãos, nos debates democráticos. Afinal, um paradigma máximo de justiça requer uma estrutura completa de justificação, que revela, além do status de participação, a distribuição de direitos, oportunidades e bens que cidadãos de uma sociedade justa não poderiam negar aos demais ${ }^{538}$.

Essa ideia de amplificação da participação, uma vez estendida para todos como pares e combinada com a possibilidade de competição política, tem a capacidade de alterar a própria ideia da representação e liderança política. O sistema, quanto mais aberto às críticas e ao conflito e mais inclusivo, será mais necessário que os políticos busquem apoio e diálogo com os grupos inseridos na vida política ${ }^{539}$. É a partir dessa relação argumentativa crítica que se inserem os mecanismos de participação direta como mediadores entre Estado e sociedade civil, ou seja, ela atua na interseção entre a esfera pública e esfera privada ${ }^{540}$.

É preciso enfrentar o problema de que, através do poder adquirido com a institucionalização da participação direta, deve-se buscar caminhos para aproximar-se de uma verdadeira democracia - poliarquia nas palavras de Dahl que se apresenta como um regime altamente inclusivo e extensivamente aberto para a contestação pública ${ }^{541}$. Permitindo uma maior aderência à democracia radical: democracia "é a ação que arranca continuamente dos governos

\footnotetext{
${ }^{536}$ FORST, R., Justification and Critique: Towards a Critical Theory of Politics, p. 106.

${ }^{537}$ Mark Haugaard em ALLEN, A.; FORST, R.; HAUGAARD, M., Power and Reason, Justice and Domination: a conversation, p. 24.

${ }^{538}$ FORST, R., op. cit., p. 115-116.

${ }^{539}$ DAHL, R. A., Polyarchy: Participation and Opposition, p. 20-23.

${ }^{540}$ AVRITZER, L.; COSTA, S., Teoria Crítica, Democracia e Esfera Pública: Concepções e Usos na América Latina, p. 706.

${ }^{541}$ DAHL, R. A., op. cit., p. 8 e 215.
} 
oligárquicos o monopólio da vida pública e da riqueza a onipotência sobre a vida" 542 .

Em suma, o modelo misto democrático trata da possibilidade de remediar a apatia e insatisfação dos cidadãos com a democracia representativa. Reaproximando os mesmos dos processos decisórios com base em uma perspectiva ideal de democracia que efetive padrões básicos de realidade ${ }^{543}$. Para isso é preciso que haja mecanismos institucionalizados capazes de quebrar a lógica dominadora dos sistemas financeiro e burocrático que se apropria do mundo político. Um dos maiores exemplos a ser combatido é o agir estratégico implementado nas grandes corporações midiáticas, já que elas transformam os cidadãos em meros receptores dando uma forma esquizofrênica aos espaços de intercâmbio social. Nessa lógica da mídia de massa não cabem verdades comunicativas, tampouco troca de razões ${ }^{544}$, é uma lógica dominadora despreocupada com estruturas de justificação. O sistema político deve localizar-se naquela mencionada interseção entre a esfera pública e privada, com a possibilidade de gerar procedimentos decisórios vinculantes através de práticas de justificação suficientemente institucionalizadas - os mecanismos de participação direta $^{545}$. Trata-se da possibilidade de relacionamento entre os públicos formados dentro da noção de Estado - governador representativo -, incluindo mecanismos de participação indireta e direta, e dos públicos formados fora desse ambiente, onde as esferas públicas sofrem interferência de contrapúblicos subalternos formados na liberalidade do mundo da vida ${ }^{546}$.

\footnotetext{
542 RANCIÈRE, J., O ódio à democracia, p. 121.

${ }^{543}$ PERES, P. S., A barganha nas vísceras do modo brasileiro de governar, p. 7.

${ }^{544}$ AVRITZER, L.; COSTA, S., Teoria Crítica, Democracia e Esfera Pública: Concepções e Usos na América Latina, p. 718.

${ }^{545}$ FORST, R., Justification and Critique: Towards a Critical Theory of Politics, p. 106.

${ }^{546}$ No que toca a ideia de esfera pública e a formações dos (mini)públicos como instrumentos de participação direta, dois registros são importantes. Primeiro, mesmo tendo registrado que não desejo entrar na separação absoluta entre esfera pública e privada, pelos problemas excludentes que essa noção pode registrar no modelo habermasiano, não posso deixar de utilizar a expressão. Por esse motivo, há uma noção crítica interessante de Fraser em relação à esfera pública: “a esfera pública, em resumo, não é o Estado, mas a mobilização informal de corpos discursivos informais de opinião, que podem servir como contrapesos ao poder do Estado". Mesmo que a autora diga que se trata de uma forma burguesa de tratar os minipublicos como fracos, entendo, que a esfera pública, uma vez institucionalizada, pode representar minipublicos fortes. FRASER, N., Rethinking the Public Sphere: A Contribution to the Critique of Actually Existing Democracy. p. 75. A partir da contestação da noção de esfera pública, Fraser vai trabalhar com a ideia de contrapúblicos subalternos que são arenas discursivas paralelas, onde é possível que os membros
} 
A necessidade de se falar em institucionalização parte justamente dessa perspectiva de mediação entre Estado e sociedade civil, de aproximação entre governo e cidadão, dentro de uma esfera pública capaz de incorporar os problemas das esferas privadas, através da participação aberta a todos os integrantes da comunidade $^{547}$. Assim, apesar de ser difícil reduzir a amplitude e vagueza do que significa institucionalizar para os objetivos desta pesquisa, alguma noção tem que ser delineada. Pode-se adiantar que a determinação do que significa institucionalizar não será fechada, já que não se pensa em instituição apenas como reconhecimento legal oficial, por meio das estruturas positivas do Estado de Direito. A ideia de institucionalização tem relação com padrões normativos positivos ou não - existentes na sociedade. Adiante, o Direito e a lei formal serão mencionados como forma de institucionalidade, não significando que se trata somente disso, quando se defende a necessidade de institucionalização do discurso, através da utilização dos mecanismos de participação direta. Mais importante do que a pergunta sobre o que significa institucionalizar são as perguntas do que institucionalizar, como e para quê.

Institucionalizar significa criar estruturas de conduta que são reconhecidas geral e reciprocamente por todos, significa estabelecer regras tácitas de justificação que apliquem-se ao processo discursivo de relacionamento intersubjetivo. Ainda que os objetivos éticos sejam diferentes, é preciso que haja uma aderência dos sujeitos às institucionalizações pela própria vontade. A ideia institucional da participação direta vem para suprir a completa ausência de marcos regulatórios de convivência institucional intersubjetiva entre sociedade, Estado e sujeito $^{548}$. Trata-se de estabelecer um critério normativo para ligar os diversos movimentos sociais e políticos no objetivo comum de demandas democraticamente orientadas ${ }^{549}$, esse objetivo comum não trata de uma noção de

de grupos dominados assumam protagonismos nos discursos que acabam por transformar-se em contra-discursos, possível de gerar reconhecimento, justificação e comunicação. Ibidem, p. 67.

${ }^{547}$ Uma dos exemplos de questão que não pode ficar de fora da esfera pública é a questão da desigualdade social, Fraser diz que deve ser objetivo próprio da esfera pública acabar com as desigualdades sociais. $\mathrm{O}$ que não significa que todos devem ter a mesma renda, mas que as diferenças não podem ser suficientes para estabelecer cenários de dominação. Ibidem, p. 65.

${ }^{548}$ PERES, P. S., A barganha nas vísceras do modo brasileiro de governar, p. 3 e 10.

${ }^{549}$ FRASER, N.; HONNETH, A., Redistribution or Recognition? A political-philosophical exchange, p. 121. 
boa vida ou bem comum, mas da própria perseguição de estruturas completas de justificação - perseguição da democracia.

A institucionalidade dos critérios de justiça aqui defendidos relacionam-se com experiências de injustiça social que só podem ser medidas dentro desses cenários, onde as possibilidade de legitimação e justificação estão adstritas a uma noção institucionalizada de regulação ${ }^{550-551}$. A institucionalização de parâmetros normativos procedimentais também sofre críticas de teóricos da democracia radical e de correntes que defendem o caráter normalizador e excludente das instituições dos Estados capitalistas. Como se defendeu acima, a reconstrução parte da possibilidade de aproveitamento das estruturas existentes, no modelo democrático atual. Dessa forma, não é possível ver a regulação institucional da cidadania como algo ruim, por essência; apenas torna primordial que essa regulação seja produtora de inclusão social e igualdade política ${ }^{552}$. Contra as correntes que criticam os caminhos institucionais de alteração do status quo dominante, é possível usar o argumento de Dahl de que mesmo as mais bem sucedidas alternativas radicais, como as revoluções, falharam em seus objetivos de atingir uma poliarquia, motivo pelo qual o caminho institucional não pode ser rejeitado por princípio $^{553}$. Ou ainda, o argumento de Benhabib que, mesmo reconhecendo as concepções de diferença e heterogeneidade como fundamentais para uma eticidade de comunidades democráticas, critica os teóricos da diferença por lhes faltar uma conclusão sobre onde se encontra o limite da defesa do diferente para que não se torne uma defesa de valores antidemocráticos ${ }^{554}$.

A institucionalidade aparece como procedimento capaz de garantir que as formações de vontades espontâneas sejam levadas para a esfera decisória; é a própria mediação capaz de gerar a migração das forças de ações coordenadas -

\footnotetext{
${ }^{550}$ FRASER, N.; HONNETH, A., Redistribution or Recognition? A political-philosophical exchange, p. 129.

${ }^{551}$ Colin Crouch registra, por exemplo, que sujeitos como o preto, pobre e trabalhador só transforma sua identidade social em identidade política quando ele descobre que é excluído, justamente, por ser pobre, preto, trabalhador e não proprietário. CROUCH, C.; PORTA, D. d.; STREECK, W., Democracy in neoliberalism?, p. 507-508. A defesa dos mecanismos de participação direta como benéficos por desnudarem situações de dominação e não reconhecimento aparece de acordo com esse raciocínio.

${ }^{552}$ AVRITZER, L., Impasses da Democracia no Brasil, p. 25.

${ }^{553}$ DAHL, R. A., Polyarchy: Participation and Opposition, p. 209.

${ }^{554}$ BENHABIB, S., Democracy and Difference: Reflections on the Metapolitics of Lyotard and Derrida, p. 3.
} 
típicas do mundo da vida - para o plano político. Isso só não pode ocorrer de forma para burocratizar a comunicação, que é a forma discursiva necessária para o entendimento no espaço de troca de razões e para os processos de legitimação ${ }^{555}$.

É um verdadeiro desafio de democratizar a democracia, mas que precisa seguir em frente com a institucionalização dos padrões básicos de convivência democrática, inclusive considerando as formações de governo, mencionadas no item anterior em relação à governabilidade ${ }^{556}$. Institucionalizar, nesse caso, significa reativar e multiplicar os espaços e processos de comunicação pública, mesmo que existam, a despeito das estruturas parlamentares e dos poderes dominadores sistêmicos ${ }^{557}$. Institucionalizar significa mobilizar os grupos subrepresentados, levando-os com suas demandas para a arena política com intenção de pluralização de políticas sociais e marcos regulatórios ${ }^{558}$.

Obviamente, que as lutas por reconhecimento são catalisadas pelos padrões de não reconhecimento, desconsideração, humilhação e desrespeito. Mas a institucionalização do discurso - ou da própria intersubjetividade - é um considerável avanço do ponto de vista do reconhecimento político que apoia as lutas contra injustiças econômicas. Dentro da própria teoria política, é necessário pensar em reestruturações institucionais capazes de remediar a má-distribuição de renda e a ausência de reconhecimento. Até mesmo porque os padrões culturais que subalternizam determinados grupos estão institucionalizados e, por esse motivo, conseguem perpetuar grupos dominantes, enquanto formas de não reconhecimento e de subordinação. Nada mais lógico que contra-atacar com formas institucionalizadas de abertura crítica aos padrões estabelecidos, retirar da exclusão a sua forma institucionalizada ${ }^{559}$. É interessante pensar em estratégias de

\footnotetext{
${ }^{555}$ AVRITZER, L.; COSTA, S., Teoria Crítica, Democracia e Esfera Pública: Concepções e Usos na América Latina, p. 706-710.

${ }^{556}$ PERES, P. S., A barganha nas vísceras do modo brasileiro de governar, p. 2 e 14.

${ }^{557}$ AVRITZER, L.; COSTA, S., op. cit., p. 711.

${ }^{558}$ COSTA, S., Desigualdades, interdependências e afrodescendentes na América Latina, p. 137. E FRASER, N., Rethinking the Public Sphere: A Contribution to the Critique of Actually Existing Democracy, p. 75-76.

559 FRASER, N.; HONNETH, A., Redistribution or Recognition? A political-philosophical exchange, p. 24-29.
} 
enfrentamento cruzado, em que se usam meios específicos de determinada dimensão de justiça para enfrentar também a outra ${ }^{560}$.

Outra função necessária e benefício da institucionalização é a possibilidade de combater a ausência dos consensos linguísticos entre diferentes mundos da $v{ }^{5} a^{561}$. Como se falou anteriormente, em contextos de grande desigualdade social, é possível que o mundo de estranhos se coloque de tal forma que acabe desconstituindo o background comum para a comunicação dos sujeitos. Dessa forma, é preciso que haja uma ação estratégica capaz de orientar a construção desse background para orientar o mútuo entendimento ${ }^{562}$. Nesse caso, a institucionalização atua como possibilidade de mediação entre os diferentes mundos da vida, conservando os padrões de comunicação e justificação, ainda que haja uma ação estratégica orientada para o fim da construção de um background necessário para a comunicação. Compreendendo todo esse objetivo da institucionalização, pode-se registrar que: “o objetivo é criar uma estrutura social onde indivíduos sejam capazes de reconhecer a si próprios como autônomos no especial sentido político de serem coautores das instituições e leis que lhes vinculam" $" 563$.

A menção aos dispositivos legais, enquanto institucionalizadores, é pertinente. Por um lado, o Direito aparece como ferramenta capaz de mediar as relações ente sistema e mundo da vida, por outro, ele deve ser tratado com cautela para que da formulação da lei e do direito não advenham normalizações excludentes. Por esse motivo, as leis gerais e abstratas devem ser compelidas a excluir todo interesse que não possa ser justificado genérica e reciprocamente ${ }^{564}$.

Não se pode esquecer de que "na imutabilidade da lei, não é o universal da ideia que o homem democrático honra, mas o instrumento de seu bel-prazer". Ou

560 FRASER, N.; HONNETH, A., Redistribution or Recognition? A political-philosophical exchange, p. 83.

${ }^{561}$ WARREN, M. E., Deliberative Democracy and the Corruption of Speech, p. 7-8.

${ }^{562}$ HABERMAS, J., The Theory of Communicative Action: The Critique of Functionalist Reason. V. 2., p. 121.

${ }^{563}$ Tradução livre. No original, em inglês: "They aim to create a social structure in which individuals are able to recognize themselves as autonomous in the specifically political sense of being co-creators of the institutions and laws that are binding on them." FORST, R., Justification and Critique: Towards a Critical Theory of Politics, p. 108.

${ }^{564}$ HABERMAS, J., Soberania Popular como Procedimento: um conceito normativo de espaço público p. 102. 
seja, a lei também é usada para garantir ações estratégicas egoístas e hierarquizadoras, mesmo que isso não seja fundamentado em princípio algum ${ }^{565}$. Apesar da defesa que se faz de um modelo institucionalizado e procedimental, a forma legal não garante a existência da democracia ${ }^{566}$, até mesmo porque a soberania popular registrada em cada sujeito vai além dessas formalidades definidas, devendo pressupor a possibilidade de redefinição constante ${ }^{567}$. Não foi outro o argumento defendido, quando se apresentou o princípio de justificação como um princípio político reflexivo que deve lidar de forma contextual e flexível com as realidades democráticas ${ }^{568}$.

Entretanto, no mundo pautado pela forma jurídico-política que se apresenta hoje, é possível depender da lei e do Direito para garantir a resistência do mundo da vida em relação à autonomia sistêmica do mundo financeiro e burocrático que coloniza a polis. A característica de autorregulação econômica do Estado e as comodificações que se colocam sobre as relações intersubjetivas podem ser combatidas através de uma institucionalização, via lei, da independência do mundo da vida em relação ao sistema - na forma de direitos humanos, por exemplo. Ou de forma mais ousada, usar a lei para garantir que as formas comunicacionais do mundo da vida migrem para o mundo político, retraindo a colonização da esfera pública pelos sistemas financeiros e burocráticos. ${ }^{569}$

Essa possibilidade de utilização do Direito, como força de alteração de sentido do vetor de colonização do mundo da vida, não pode ignorar o abismo entre Direito e sociedade em países marcados por desigualdades sociais. A estrutura social e normativa evidencia uma ausência de legitimidade da própria lei. Por isso, a atenção deve voltar-se para os espaços de discussão e mediação entre as esferas públicas e privadas na forma de procedimentos legais ${ }^{570}$.

\footnotetext{
${ }^{565}$ RANCIÈRE, J., O ódio à democracia, p. 56.

${ }^{566}$ Legalidade e legitimidade estão próximas mas não são a mesma coisa. Uma lei promulgada pode ser ilegítima. BENHABIB, S., Democracy and Difference: Reflections on the Metapolitics of Lyotard and Derrida, p. 9.

${ }^{567}$ RANCIÈRE, J., op. cit., p. 71-72.

${ }^{568}$ FORST, R., Justification and Critique: Towards a Critical Theory of Politics, p. 114.

${ }^{569}$ DEFLEM, M., Introduction: law in Habermas's theory of communicative action, p. 6-7.

570 GUIBENTIF, P., Approaching the production of law through Habermas's concept of communicative action. p. 62.
} 
A lei precisa assumir um papel duplo, ativo e passivo, ao mesmo tempo em que auxilia na formação de estruturas discursivas de justificação, ela também está submetida aos critérios normativos de justificação. É preciso que haja um empreendimento cooperativo para formulação da legislação, com perspectivas intersubjetivas. A própria autonomia do cidadão depende desse reconhecimento na dimensão legal e da estima - de que ele é coautor da lei a qual se submete ${ }^{571}$. A lei também deve ser utilizada como meio vinculante da institucionalização dos mecanismos de participação direta, aparecendo como forma legal de procedimento decisório capaz de nortear a administração a garantir o espaço de troca de razões necessário à democracia.

Uma vez estabelecido que a democracia depende de estruturas de justificação - relações de poder e tolerância como respeito, não dominação - para qualificar-se como tal, essas estruturas precisam basear-se em espaços de encontro dos diferentes com discursos orientados para o entendimento e isso é viável ao incluir mecanismos de participação direta no sistema representativo, de forma institucionalizada, através do Direito ou não; resta delinear os caminhos que esse modelo democrático reconstrutivista pode percorrer. Não se oferece um meio exato de determinada forma de participação ou de sugestão de regras procedimentais do debate. Apenas aponta-se para um norte que deve ser objetivado para encontrar uma verdadeira democracia com proposições que caibam dentro das teorias normativas articuladas ao longo do trabalho.

Os mecanismos de participação direta, ao combinar-se com formas de representação devem objetivar estratégias de descentralização e redefinição institucional, além da multiplicação de públicos deliberativos. É a possibilidade de estabelecer uma relação de confiança inversa, em que há uma confiança e delegação da esfera decisória típica do Estado para a sociedade ${ }^{572}$. Na esteira da perspectiva de uma democracia deliberativa, trata-se de "estender a racionalidade comunicativa aos processos decisórios, assegurando-se, institucionalmente, a existência de fóruns deliberativos" $" 573$.

${ }^{571}$ HABERMAS, J., The Inclusion of the Other, p. 31 e 71.

572 POGREBINSCHI, T., The Pragmatic Turn of Democracy in Latin America, p. 4.

${ }^{573}$ AVRITZER, L.; COSTA, S., Teoria Crítica, Democracia e Esfera Pública: Concepções e Usos na América Latina, p. 714. 
A multiplicação de minipúblicos insere-se na perspectiva de Fraser em relação a possibilidade de contrapúblicos subalternos, institucionalizados ou não. É uma abordagem descolada da noção de esfera pública habermasiana que entende como sendo melhor, do ponto de vista democrático, que a esfera pública seja composta por diversos minipúblicos, na espécie de contrapúblicos ou não. Assim, seria possível realizar melhor as condições de justificação e comunicação em relação aos sujeitos tradicionalmente excluídos da esfera pública e do processo decisório político ${ }^{574}$. Os contrapúblicos subalternos de Fraser criticam uma unificação nacional dos espaços políticos, uma vez que uma esfera pública nacional, única e abrangente pode não considerar as relações assimétricas ${ }^{575}$.

É preciso que os espaços de participação direta suprimam o culto à individualidade e à universalidade que impede a formação de reconhecimento intersubjetivo entre os diferentes. Afinal, na perspectiva dominadora, a individualidade egoísta só serve às elites ${ }^{576}$, acrescentando às sociedades apenas nas noções de autonomia. Um dos pontos fundamentais de uma democracia mista reconstruída sobre um princípio de justiça é a possibilidade de evitar juízos arbitrários ou de dominação ${ }^{577}$. A noção de legitimação dos procedimentos democráticos relaciona-se intrinsecamente com a ideia de injustiça social com um forte componente de reconhecimento social. Dessa forma, um modelo democrático não pode restringir-se às formas de luta por reconhecimento e redistribuição dentro dos espaços decisórios típicos de democracias exclusivamente representativas. É preciso deslegitimar a normatividade

\footnotetext{
574 O ponto de Fraser é explorado de maneira perfeita em seu artigo em relação a esfera pública de Habermas. Há uma forte crítica à noção de esfera pública unificada e "protegida" de coerção externa de Habermas, onde a autora cria e adota a posição dos contrapúblicos subalternos. Acredito que esta linha seja melhor para a argumentação que se fez ao longo do trabalho, mas não pretendo adentrar na discussão em relação ao modelo de esfera pública de Habermas. Apenas compreendo que as perspectivas habermasianas trazidas para esta pesquisa não são incompatíveis com a formulação de Fraser em relação aos contrapúblicos subalternos. Idem nota 546. Para maiores informações sobre a questão ver artigo completo: FRASER, N., Rethinking the Public Sphere: A Contribution to the Critique of Actually Existing Democracy.

${ }^{575}$ AVRITZER, L.; COSTA, S., Teoria Crítica, Democracia e Esfera Pública: Concepções e Usos na América Latina, p. 711.

${ }^{576}$ RANCIÈRE, J., O ódio à democracia, p. 42.

${ }^{577}$ FORST, R., The Right to Justification: elements of a constructivist theory of justice, p. 19.
} 
injustificada, principalmente, no que se refere à perspectiva distributiva ${ }^{578}$. Não se trata de um pulo, mas de um caminho para igualdade social ${ }^{579}$.

A democratização da democracia pode caminhar pela construção de instituições que incentivem as experiências em que o cidadão aprende ou é induzido a aproximar-se do conflito político. É preciso que as democracias desenvolvam, de maneira saudável, uma ordem de confiança nos procedimentos decisórios, tornando-os sempre objetos de compromisso intersubjetivo ${ }^{580}$. Isso está diretamente ligado às crenças políticas de cada um, o que pode ser problemático, já que adquirir ou perder uma crença política é difícil e sacrificante. Mas essa possibilidade só pode ser viabilizada através do aumento da exposição do sujeito ao diferente, que pode ocorrer de diversas formas, possuindo uma entrada maior nas formas diretas de participação política ${ }^{581}$.

Tudo isso precisa ser reconhecido pelas autoridades que ocupam postos decisórios nas democracias representativas, eles precisam tornar-se dependentes da responsividade aos cidadãos dentro da esfera pública argumentativa ${ }^{582}$. Uma estratégia fundamental para estabelecer estruturas de justificação é a necessidade de tencionar relações hierarquizadas que só ampliam as desigualdades dentro das relações sociais ${ }^{583}$.

Sobretudo, o êxito de um processo de democratização brasileira depende da capacidade das instituições democráticas representativas e participativas produzirem políticas sociais inclusivas da população de baixa renda ${ }^{584}$. É a utilização instrumental dos paradigmas de reconhecimento intersubjetivo contidos nas teorias de Honneth para desconstruir as estruturas normativas de desigualdade injustificadas. O próprio Estado-Social e as políticas públicas de reconhecimento simbólico ou material são formas de desmeritocratização da dimensão da estima. A meritocratização da dimensão da estima contém superimposições e distorções inerentes a uma ideia de conquista do sistema capitalista, que não é compatível

\footnotetext{
578 FRASER, N.; HONNETH, A., Redistribution or Recognition? A political-philosophical exchange, p. 132 e 151.

${ }^{579}$ FORST, R., The Right to Justification: elements of a constructivist theory of justice, p. 195.

${ }^{580}$ WARREN, M. E., Deliberative Democracy and the Corruption of Speech, p. 19-21.

${ }^{581}$ DAHL, R. A., Polyarchy: Participation and Opposition p. 169-170.

582 Ibidem, p. 220-221.

${ }^{583}$ MARTINS, P. G.; GONTIJO, L. A., Teoria do Reconhecimento e Economia Solidária: uma proposta de recomposição entre igualdade e solidariedade, p. 207.

${ }^{584}$ AVRITZER, L., Impasses da Democracia no Brasil, p. 24.
} 
com qualquer princípio normativo de reconhecimento mútuo em sociedades desiguais $^{585}$.

A capacidade de inclusão das formas de participação direta é também uma forma de reconhecimento mútuo intersubjetivo. Diante do encontro do diferente, possível em espaços públicos de deliberação não hierarquizados, os sujeitos podem aprender e trocar informações relativas às suas identidades. É um processo de alternação de estágios, reconciliação e conflito. São esses conflitos que parecem equipar os sujeitos com ferramentas para a vida em sociedade, é somente através dos atos de confrontação das estruturas sociais que pode advir o reconhecimento ${ }^{586}$.

$\mathrm{Na}$ linha das teorias normativas trabalhadas ao longo da pesquisa, é possível selecionar algumas indicações capazes de contribuirem para o argumento em favor do modelo democrático misto reconstruído ${ }^{587}$. Nas perspectivas de Sérgio Costa e Avritzer, a transição para uma melhor democracia requer: (i) necessidade de incorporar diversidade no espaço público; (ii) dar relevância aos grupos tradicionalmente excluídos - formação de contrapúblicos; (iii) e a já mencionada multiplicação dos públicos participativos e deliberativos ${ }^{588}$. O caminho de Warren vai pela noção de que política é conversa, de forma que os argumentos precisam valorizar o diálogo como centralidade democrática, registrando que, diante de contextos comunicativos, as decisões (i) são melhores, epistemologicamente, porque são resultado de melhores informações e perspectivas; (ii) são melhores, na perspectiva ética, porque tendem a considerar interesses e perspectivas de todos os afetados, tendendo à justiça; (iii) tendem permitir melhor autonomia aos

\footnotetext{
${ }^{585}$ Honneth afirma que, nas sociedades capitalistas atuais, a dimensão da estima muda de um paradigma de honra e solidariedade para uma perspectiva de mérito, em que o sujeito precisa se esforçar dentro do jogo social e das formas de produção e trabalho para adquirir o status de membro como igual. Essa substituição fortalece as formas de não reconhecimento, já que é impossível desconhecer o fato de que os sujeitos não entram nos jogos competitivos capitalistas com as mesmas armas. De forma que atingir as expectativas de uma normatividade social desigual e hierarquizada pode se tornar impossível, imobilizando e tornando invisível o sujeito desrespeitado e humilhado. FRASER, N.; HONNETH, A., Redistribution or Recognition? A political-philosophical exchange, p. 147-148.

${ }^{586}$ HONNETH, A., The Struggle for Recognition: The Moral Grammar of Social Conflicts, p. 1723.

587 Tomo a liberdade de escolher três abordagens para esse momento, enumerando apenas seus apontamentos mais pertinentes e, ainda assim, correndo o risco de tornar a lista um pouco cansativa. $\mathrm{O}$ que revela a multiplicidade de caminhos e pequenas ações possíveis para concretizar uma democracia baseada em um princípio da justificação.

${ }^{588}$ AVRITZER, L.; COSTA, S., Teoria Crítica, Democracia e Esfera Pública: Concepções e Usos na América Latina, p. 722-723.
} 
cidadãos, individual e coletivamente, de forma autorreflexiva; (iv) têm maior qualidade de legitimação ${ }^{589}$.

Conforme expõe Boaventura, é necessário quebrar o paradigma democrático liberal promovendo o que o autor chama de reinvenção da emancipação social. É necessário defender as democracias contra-hegemônicas, introduzindo e desestabilizando o paradigma da representatividade como sistema deliberativo da democracia $^{590}$, expondo o que segue:

(i) "a demodiversidade" - deve-se estar sempre procurando a utilização de mecanismos que viabilizem a expressão multifacetada desse organismo vivo que é a população; nesse sentido, defende-se a demodiversidade buscando sempre intensificar a democracia e, nos parâmetros de hoje, a complementação entre a democracia participativa e a democracia representativa ${ }^{591}$;

(ii) "o local e o global" - deve-se afirmar que é possível a mencionada complementaridade entre os sistemas, nas escalas nacionais e globais, sempre privilegiando uma forma ativa de expressão da pluralidade e da diversidade ${ }^{592}$;

(iii) "a democracia participativa" - é fundamental a utilização de mecanismos típicos da democracia participativa para reconhecimento dos catalisados processos de pluralização cultural pelos quais passam as comunidades, representando profundas redefinições na prática democrática; tanto a coexistência como a complementaridade são possíveis entre os mecanismos de deliberação da democracia representativa e da participativa; nesse sentido, deve haver um reconhecimento de um procedimentalismo participativo, colocando diretamente na mão do povo o monitoramento do governo e os processos de deliberação pública que devem permear os esquemas representativos ${ }^{593}$.

Em uma democracia reconstruída que encontra sua legitimidade nos procedimentos deliberativos com a presença de todos, orientados por todos esses caminhos, cabe menção, do ponto de vista teórico e prático, aos benefícios que podem resultar dos caminhos defendidos aqui. Do ponto de vista teórico, é

\footnotetext{
${ }^{589}$ WARREN, M. E., Deliberative Democracy and the Corruption of Speech, p. 6.

${ }^{590}$ SANTOS, B. de S.; ARVRITZER, L., Introdução: para ampliar o cânone democrático, p. 71.

${ }^{591}$ Ibidem, p. 71-72.

592 Ibidem, p. 73-74.

${ }^{593}$ Ibidem, p. 75-76.
} 
possível afirmar que esse modelo é melhor por encontrar um caminho intermediário entre as noções de democracias como cooperação ou como conflito. Da mesma forma que um modelo democrático desprovido da capacidade de cooperação - baseado apenas no conflito - é completamente ineficaz e engessado, não se pode pensar em modelos democráticos desprovidos de conflitos, já que seria uma utopia utilizada apenas para excluir os grupos dominados e/ou subrepresentados.

A democracia não pode ser lida de acordo com nenhuma dessas perspectivas extremas, uma vez que as relações sociais são, em essência, cooperativas e competitivas ao mesmo tempo, é isso que as torna saudável e progressistas. A concepção de uma democracia - ou poliarquia - depende de que haja cooperação e conflito em todas as instituições decisórias, o que inclui eleições, partidos, parlamentos e mecanismos de participação direta ${ }^{594}$.

Pode-se ainda mencionar que o modelo proposto aumenta a capacidade de socialização entre os diferentes no plano político, onde um indivíduo tem a possibilidade de expressar-se de forma comunicativa apresentando suas preferências políticas. O quanto maior o número de preferências e interesses presentes no debate público, maiores as chances de políticas públicas mais representativas ${ }^{595}$. A atuação de forma comunicativa aumenta as relações de reconhecimento intersubjetivo e a própria autonomia dos sujeitos, uma vez que o cidadão é encorajado, pela própria estrutura intersubjetiva linguística comunicativa, a continuar a ser como ele mesmo. Gera-se também uma identificação com as normatividades estabelecidas, o que pode aumentar a possibilidade de comportar-se de acordo com as normas ${ }^{596}$.

Em um aspecto mais empírico, Thamy Pogrebinschi fala em pesquisas que demonstram como a virada pragmática é capaz de aumentar a confiança e a satisfação dos cidadãos na democracia ${ }^{597}$. No mesmo sentido, Dahl vai registrar que a crença nas capacidades democráticas do governo tem relação direta com a socialização política e a performance de diferentes regimes. Ainda, dizendo que

\footnotetext{
${ }^{594}$ DAHL, R. A., Polyarchy: Participation and Opposition, p. 153-155 e 160.

595 Ibidem, p. 26.

${ }^{596}$ HABERMAS, J., Pensamento Pós-Metafísico, p. 227.

597 POGREBINSCHI, T., The Pragmatic Turn of Democracy in Latin America, p. 14.
} 
uma vez que falhas de governos e má-performances econômicas são comuns em países de grande desigualdade, a participação pode assumir um papel de porto seguro, como um backup de legitimação e confiança no governo ${ }^{598}$. Aqui, há um compartilhamento da responsabilidade entre representantes e representados, que somente é possível, quando também se compartilha os procedimentos decisórios ${ }^{599-600}$.

A expansão da participação democrática em modelos representativos é a abertura de canais entre sociedade civil e governo, a abertura do núcleo decisório - até então restrito - que resulta na redução do clientelismo através de uma legislatura mais responsiva, no aumento da transparência e na experimentação de novas formas de interação entre cidadão e Estado, entre classes baixas e elite política $^{601}$. Dentro dessas formas de interação, praticamente inexistentes entre os diferentes mundos da vida em sociedades desiguais, a abertura que se propõe pode desnudar cenários de desrespeito e ausência de reconhecimento; fornecendo as possibilidades para uma luta por reconhecimento que pressupõe a identificação da estrutura institucional como não legítima e injustificada ${ }^{602}$.

Sobretudo, um dos benefícios mais importantes para as preocupações dessa pesquisa, garantido pelo aumento da participação democrática e já experimentado e comprovado, é a capacidade de gerar inclusão social. Com uma guinada em 2003, os fóruns de participação direta utilizados na Administração Pública Federal garantiram a formulação de políticas públicas transformadoras do aspecto da renda dos brasileiros. A diminuição da Classe E - pobres - é um exemplo das positividades geradas pelo aumento qualitativo da democracia, através de políticas, como a valorização do salário mínimo, formuladas, pensadas e debatidas em conferências, conselhos e outros fóruns nacionais de participação ${ }^{603}$. A

\footnotetext{
${ }^{598}$ DAHL, R. A., Polyarchy: Participation and Opposition, p. 148-149.

${ }^{599}$ MARTINS, P. G.; GONTIJO, L. A., Teoria do Reconhecimento e Economia Solidária: uma proposta de recomposição entre igualdade e solidariedade, p. 208.

${ }^{600}$ Esse benefício de compartilhamento da responsabilidade trazido pelo caminho proposto é algo de grande valia para as democracias sul-americanas, marcadas por interrupções de mandatos e de regimes em razão de má-performance econômica.

${ }^{601}$ POGREBINSCHI, T., The Pragmatic Turn of Democracy in Latin America, p. 13.

602 FRASER, N.; HONNETH, A., Redistribution or Recognition? A political-philosophical exchange, p. 157.

603 AVRITZER, L., Impasses da Democracia no Brasil, p. 20.
} 
montagem de uma estrutura de justificação procedimental garante uma diminuição nas estruturas injustificadas de distribuição de renda.

Gostaria de encerrar o capítulo com duas importantes notas. A primeira delas é que a defesa da institucionalização do discurso, feita neste item, não pode ignorar a necessidade de reconhecimento das ações e manifestações de rua. Conforme explicado no item 2.2., Forst compreende as manifestações e performances, inclusive corporais, como formas de troca de razão, o que é constitutivo dos espaços de justificação e das relações de poder necessárias ao ambiente democrático que se pretendeu apresentar aqui. Para que não haja dúvidas: os protestos e manifestações são formas de ação racional que precisam integrar a equação decisória do Estado ${ }^{604}$.

Quero registrar outra nota que é meramente uma ilustração empírica do que pode ser a aplicação, no mundo real, dos caminhos propostos, além do reconhecimento de que a abordagem não traz nada de efetivamente novo. Basta amplificar o que já existe, tratar de maneira mais profunda da institucionalização da participação direta e adentrar áreas às quais é negada sua inserção, tais como o controle de corrupção e infraestrutura, conforme explicado no primeiro capítulo. Portanto, encerro dizendo que a Lei n. $^{0}$ 8.142/1990 que dispõe sobre a participação da comunidade na gestão do Sistema Único de Saúde - SUS - é um exemplo de institucionalização discursiva do controle social que se exerce, nesse caso, inclusive sobre o orçamento. Os Conselhos de Saúde, por exemplo, são mecanismos de contrapeso à autoridade conferida aos Poderes Executivos dos entes federados. Nas palavras de Francisco Fonseca:

[a lógica do SUS] sintetiza o sentido expandido de democracia, como afirmamos, pois articula a política social: à lógica do sistema, com predominância federal na articulação das políticas com os entes federados; ao papel específico do município; à constitucionalização das verbas; e à participação popular. Em outras palavras, elementos federativos - institucionais portanto - somam-se à participação política, sobretudo popular, via conselhos gestores, e à ampliação dos direitos de cidadania, respondendo assim, de certa forma, aos desafios do capitalismo contemporâneo. ${ }^{605}$

\footnotetext{
${ }^{604}$ MATOS, A. R., "Eu participo, tu participas...nós protestamos": ações de protesto, democracia e participação em processos de decisão, p. 121.

${ }^{605}$ FONSECA, F., Democracia e participação no Brasil: descentralização e cidadania face ao capitalismo contemporâneo, p. 251-252.
} 


\section{4. Conclusão}

Foram diversos pontos tratados, ao longo dos três capítulos, com os quais tentei apresentar como as formulações normativas - principalmente alemãs interferem no entendimento relativo a um modelo democrático capaz de ser visualizado, em países de grande desigualdade social que fogem das lógicas eurocêntricas. Antes de apresentar as conclusões materiais do trabalho, gostaria de registrar uma conclusão relativa ao método utilizado, nesta pesquisa. Faço questão de registrar esse ponto metodológico apenas na conclusão, uma vez que, ao iniciar o trabalho, não tinha em mente de que seria esse o caminho que seguiria, tendo descoberto apenas, durante a escrita, muito tempo após ter acumulado algum conteúdo bibliográfico referente aos autores - marcos teóricos do trabalho.

Ao começar o trabalho, tive grande preocupação em procurar autores e fontes compatíveis entre si, inclusive pelas peculiaridades dos autores da teoria crítica, principalmente os frankfurtianos. De certa forma, o trabalho reflete essa preocupação. Durante todas argumentações e todas as aproximações ou críticas que tentei apresentar entre os autores, procurei cercar-me de limitações em determinadas formulações para não utilizar, ao mesmo tempo, argumentos com bases filosóficas incompatíveis. Acredito ter obtido sucesso nessa empreitada, mesmo reconhecendo que foram arriscadas as utilizações de abordagens da democracia radical, que por princípio rejeitam o conflito, juntamente com a linha habermasiana, que trabalha para atingir acordos racionais capazes de orientar ações coordenadas.

Confesso, porém, que minha preocupação reduziu-se ao longo do trabalho, pelo simples fato de que a escolha de princípios normativos morais que norteiem um modelo democrático não pode impedir que se utilizem mecanismos e instrumentos de outras teorias normativas, ainda que, em suas bases, possuam entendimentos filosóficos completamente incompatíveis relativos ao sujeito e à própria normatividade. Foi exatamente o que fiz, escolhi o princípio da justificação de Forst, com todos os seus critérios normativos morais, como princípio de justiça que deve orientar um modelo político qualificado como democrático. Assumi as formulações relativas à ação comunicativa como base 
filosófica, com referência na teoria da linguagem, para a melhor compreensão do princípio da justificação de Forst. Utilizei instrumentos fornecidos por ambos autores para tratar do objeto selecionado. Entretanto, não me furtei - e talvez tenha feito em abundância - de utilizar os instrumentos fornecidos por outros autores, dos mais próximos como Honneth, Fraser, Dahl e até mesmo Avritzer, aos mais distantes, como Pogrebinschy, Rancière e Mouffe. Isso não significa que compartilhe todos os pontos de suas teorias e muito menos que me vincule às bases filosóficas que nortearam as formulações desses princípios. Trata-se apenas de encontrar instrumentos nas mais diversas fontes e teorias que tratam, em última instância, do mesmo objeto - o sujeito e a forma de analisar sua vida em sociedade. Espero que os pontos tenham alcançado clareza durante os capítulos apresentados e que essa suposta "equivocada" utilização de autores de tradições democráticas antagônicas não impeça o reconhecimento dos argumentos apresentados. Dito isto, vamos às conclusões da pesquisa apresentada neste trabalho.

Grande parte do desenvolvimento do trabalho consubstanciou-se em apresentar o cenário político de um país marcado pela desigualdade social como um cenário onde existem situações de dominação que comprometem a característica democrática de modelos exclusivamente representativos. Neste cenário, o operador da representação se mostrou como ambiência saudável para a presença de situações parasitárias antidemocráticas capazes de manter o cidadão distante da esfera pública decisória e perpetuar cenários históricos de ausência de reconhecimento.

Do contexto apresentado, conclui-se que, no Brasil - e em diversas democracias pelo mundo -, há situações de não reconhecimento que demonstram a ausência de intersubjetividade entre pessoas de diferentes classes sociais, culturas, grupos étnicos e outros fatores orientadores dos valores éticos subjetivos. A democracia exclusivamente representativa não é capaz de lidar com esse problema, por esse motivo, desenvolveu-se uma reconstrução do modelo representativo capaz de aumentar a qualidade democrática das ditas democracias existentes. Isso através de formulações teóricas normativas orientadas por uma visão empírica ampla de um país marcado por situações de desigualdade social e de outras formas de discriminação, como, por exemplo, o racismo. 
Tratou-se de evidenciar os déficits democráticos presentes em um modelo representativo desprovido de respaldo em uma teoria normativa de justiça baseada na justificação. Mostrando também como esses déficits consistem em deficiências ou corrupções de comunicações que interferem na incapacidade dos agentes eleitos de serem responsivos aos seus representados. Somente os mecanismos de participação direta foram capazes de apresentar possibilidades de quebras desses problemas dos modelos exclusivamente representativos.

Retomando as hipóteses formuladas para a orientação da pesquisa, acredito ter demonstrado que a democracia exclusivamente representativa facilita a existência de cenários de dominação, onde determinados sujeitos não são reconhecidos, enquanto titulares de um direito à justificação. Ficou evidenciado que contextos de larga desigualdade social agravam não só as crises de legitimidade do modelo de representação, como inviabilizam - em situações extremas - a própria existência de democracia, uma vez que comprometem o compartilhamento de mundos da vida, impedindo relações intersubjetivas de reconhecimento e perpetuando situação históricas de não reconhecimento. Não foram poucos os argumentos capazes de defender que os mecanismos de participação direta diminuem os déficits democráticos dos modelos representativos, aumentam a possibilidade do agir comunicativo na relação entre Estado e cidadão, repercutem na esfera de reconhecimento intersubjetivo e na aproximação entre mundos da vida diferentes nos contextos de desigualdade social, reduzindo a possibilidade de dominação.

Foi mais fácil desenvolver as argumentações em relação à hipótese de insuficiência do modelo representativo no Brasil. Realmente o país é palco de diferenças históricas e de situações onde os "debaixo" nunca foram considerados para moldar as instituições democráticas ou considerados nas formulações normativas que se estabelecem dentro da sociedade. É um problema de ausência de legitimidade de um sistema que parece, aos olhos desatentos, abraçar a diferença e multiplicidade de um país miscigenado, mas, em uma análise que não precisa ser muito apurada, deixa transparecer as marcas de exclusão, não reconhecimento e negação da dignidade humana baseada em um direito à justificação. 
Nos dias atuais, é possível considerar o presidencialismo de coalizão e as formas como se adquirem governabilidade como maiores exemplos de desprezo pela vontade popular e por uma noção de que as decisões políticas devem respeitar contextos comunicacionais de justificação - por isso, escolhi destacar essa parte da institucionalidade representativa. Essa é uma das marcas de contextos decisórios que impedem a aproximação dos sujeitos, negando o próprio reconhecimento dos mesmos, enquanto sujeitos com direito à justificação e sujeitos políticos. Na perspectiva intersubjetiva do reconhecimento, esses sujeitos acabam incorporando essa desconsideração subjetiva e não se reconhecendo como capazes de alterar as estruturas políticas decisórias. É uma imobilização que vem das formas de exercício da política por uma elite que, ao deter os recursos financeiros, monopoliza também as formas de influenciar as decisões públicas do país. Isso se estabelece através de uma comodificação do mundo da vida e da esfera política que se apresenta em uma noção neoliberalista de que o mercado deve conformar a democracia e, não o contrário.

Em conjunto, Habermas e Forst estabelecem parâmetros suficientes para analisar as relações entre Estado e povo, não deixando dúvida de que não se pode falar em democracia nos contextos de perpétuas desigualdades sociais como o Brasil. Simplesmente, não há forma possível de identificar uma justificação baseada nos critérios de reciprocidade e generalidade, nos cenários democráticos de desigualdades sociais gritantes como o apresentado nessa pesquisa. Tampouco é possível dizer que haja uma relação comunicativa intersubjetiva entre representante e representado, diante das constantes formas pelas quais o agir estratégico atua na colonização do mundo da vida.

Através da análise de um cenário empírico brasileiro de paradoxos democráticos, foi possível comprovar como momentos de virada pragmática democrática são possíveis de melhorar a legitimidade do sistema e sua qualidade democrática, quando baseados em amplificação da participação popular na equação decisória governamental. Os insucessos e inconstâncias da participação direta no Brasil só revelam a necessidade de amplificar os mecanismos de participação direta no contexto decisório político e em sua institucionalização. 
Essa institucionalização torna-se necessária, principalmente, como ferramenta para desinstitucionalização dos padrões normalizadores e excludentes, parasitários da representação. O modelo representativo institucionalizado não é problemático em essência, por essa razão, um caminho institucional de imputação da participação direta parece uma abordagem positiva. Nesse sentido, o Direito desde que atenda ao princípio da justificação e seja formulado em contextos comunicacionais -mostra-se como instrumento capaz de alterar o sentido do vetor de colonização do mundo da vida, fazendo com que as formas de interação típicas do mundo da vida migrem para a esfera pública decisória.

A multiplicação de minipúblicos e o reconhecimento de formas de manifestação direta, o que inclui protestos e demonstrações de rua, são caminhos capazes de aumentar a qualidade democrática do sistema porque representam uma melhora nas estruturas básicas de justificação e comunicação, além de resultarem em um aumento de reconhecimento intersubjetivo entre os sujeitos. Além de ser fato que os mecanismos de participação direta geram inclusão política e econômica, os ambientes de encontro e conflito são espaços onde é possível diminuir as distâncias entre os diferentes mundos da vida presentes em uma sociedade tão desigual. Mas isso só irá acontecer, se as formas de participação direta estiverem inseridas em contextos que se orientem pelo princípio de justiça de justificação. Isso é impossível sem uma reforma estruturante, ainda que gradual, que inclua a eliminação das diferenças injustificáveis de desigualdade social.

Em fim, é importante repetir as formulações democráticas baseadas nos marcos teóricos da pesquisa. Repetindo o que foi apresentado da análise das teorias de Habermas e Forst, o trabalho conclui que a democracia é incompatível com uma perspectiva parasitária de um agente político que deseja que os outros não se posicionem em relação à validade dos discursos em uma sociedade. A democracia precisa se resguardar dessa forma parasitária de ação, buscando o fortalecimento de uma comunicação ampla que possibilite ao indivíduo dar respostas e fazer alegações capazes de provocar, no locutor, uma adequação do discurso. É preciso que as arenas decisórias políticas fortaleçam estruturas de diálogo capazes de rejeitar a possibilidade do agir estratégico. A inclusão de mecanismos de participação direta diminuí a mediação nos modelos 
exclusivamente representativos, aumentando a possibilidade dos participantes do discurso de se posicionarem em relação as pretensões de validade dos agentes de Estado. Os mecanismos de participação direta são ações estratégicas com fim da comunicação. E, para ser justa, uma sociedade deve possuir, pelo menos, estruturas básicas de justificação baseadas em uma tolerância como respeito sem distinção entre as diferenças éticas dos participantes.

O modelo democrático reconstrutivista consiste em caminhos que não se estabelecem por si só. Não pretendi, neste trabalho, aprofundar a abordagem e ser capaz de demonstrar como de fato se acaba com a dominação típica de espaços estratégicos injustificáveis. Responder a pergunta de como é possível que um sujeito imobilizado, dominado e humilhado consiga competir com a força dos sistemas financeiros, empoderador das elites que não desejam alterar o status quo, é tarefa demasiadamente complicada. Porém, acredito que os caminhos apresentados são capazes de instigar lutas por reconhecimento e criação de espaços de justificação. Além de ser possível colocar-se de maneira crítica nas situações empíricas, identificando discursos estratégicos e posicionando-se, também de forma estratégica, para contra-atacar essas ações subalternizadoras. Pode ser um caminho longo e tortuoso, mas quem disse que a luta por uma sociedade inclusiva e democrática seria fácil? 


\section{5. \\ Referências bibliográficas}

ABRANCHES, S. A democracia brasileira vai bem, mas requer cuidados: proposições sobre democracia brasileira e o presidencialismo de coalizão. XIII Fórum Nacional, Estudos e Pesquisas, n. 5. Rio de Janeiro: INAE, 2001. Disponível em: <http://www.inae.org.br/estudo/ademocracia-brasileira-vai-bem-mas-requer-cuidados-proposicoes-sobredemocracia-brasileira-e-o-presidencialismo-de-coalizao/> Acessado em: 15 jan. 2017.

Presidencialismo de Coalizão: o dilema institucional brasileiro. DADOS. Revista de Ciências Sociais, Rio de Janeiro, v. 31, n. 1, p. 5-34, 1988.

ADVERSE, H. Republicanismo. Em: AVRITZER, L. et.al. (Org.). Dimensões políticas da justiça. Rio de Janeiro: Civilização Brasileira, 2013. P. 27-35.

Decisionismo. Em: AVRITZER, L. et.al. (Org.). Dimensões políticas da justiça. Rio de Janeiro: Civilização Brasileira, 2013. P. 77-83.

ALBUQUERQUE, W. R. Abolição e Justiça no Brasil. Em: AVRITZER, L. et.al. (Org.). Dimensões políticas da justiça. Rio de Janeiro: Civilização Brasileira, 2013. P. 271-279.

ALLEN, A.; FORST, R.; HAUGAARD, M. Power and Reason, Justice and Domination: a conversation. Journal of Political Power, 7:1, 7-33, 2014. Disponível em: <http://dx.doi.org/10.1080/2158379X.2014.887540> Acesso em: 4 abr. 2016.

ARAUJO, P. F., et. al.. Desapropriação para Megaeventos no Rio de Janeiro: interesse público de quem?. Direito em Debate. Revista do Departamento de Ciências Jurídicas e Sociais da Unijuí. Ano XXIIIm n. 41, jan-jun./2014. Disponível em: <https://www.revistas.unijui.edu.br/index.php/revistadireitoemdebate/articl e/viewFile/3035/2677> Acesso em: 10 ago. 2015.

ARAUJO, P. F.; VASCONCELLOS, U.S.C.V.; Política Nacional de Participação Social: uma busca pela efetivação do interesse público?. Reforma Política e perspectivas de democracia constitucional. Anais do II Congresso Internacional de Direito Constitucional e Filosofia Política, V.2. Belo Horizonte: Initia Via, 2016, p. 84-97. Disponível em: <https://dx.doi.org/10.17931/DCFP2015_V02> Acesso em 12 dez. 2016.

AVRITZER, L. Impasses da Democracia no Brasil. 1a ed. Rio de Janeiro: Civilização Brasileira, 2016. 
Judicialização da política e equilíbrio de poderes no Brasil. Em: AVRITZER, L. et.al. (Org.). Dimensões políticas da justiça. Rio de Janeiro: Civilização Brasileira, 2013. P. 215-219.

AVRITZER, L.; COSTA, S. Teoria Crítica, Democracia e Esfera Pública: Concepções e Usos na América Latina. DADOS. Revista de Ciências Sociais, Rio de Janeiro, v. 47, n. 4, p. 703-728, 2004.

BARROCAL, A. As derrotas do plebiscito. Carta Capital, 10 jul. 2013. Disponível em: <http://www.cartacapital.com.br/politica/as-derrotas-doplesbiscito-5185.html> Acesso em 3 jan. 2017.

BENHABIB, S. Democracy and Difference: Reflections on the Metapolitics of Lyotard and Derrida. The Journal of Political Philosophy, v. 2, n. 1, p. 1-23, $1994 . \quad$ Disponível em: <http://knowledgepublic.pbworks.com/f/benhabib.pdf> Acesso em 3 fev. 2017.

BOBBIO, N.; MATTEUCCI, .; PASQUINO, G. Dicionário de Política. $2^{\mathrm{a}}$ ed. Brasília: UNB, 1986.

BOSCHI, R. R.; SILVA, J. M. Direito e empresariado. Em: AVRITZER, L. et.al. (Org.). Dimensões políticas da justiça. Rio de Janeiro: Civilização Brasileira, 2013. P. 411-419.

BRASIL. EC n. 95/2016. Altera o Ato das Disposições Constitucionais Transitórias, para instituir o Novo Regime Fiscal, e dá outras providências. Disponível

em: <http://www.planalto.gov.br/ccivil_03/constituicao/emendas/emc/emc95.ht m> Acesso em: 03 jan. 2017.

BRASIL. Projeto de Decreto Legislativo n. 1.491/2014. Câmara dos Deputados. Disponível em: <http://www.camara.gov.br/proposicoesWeb/fichadetramitacao?idProposic ao $=617737>$ Acesso em: 5 dez. 2016.

BRASIL. Constituição (1988). Disponível em: <http://www.planalto.gov.br/ccivil_03/constituicao/constituicao.htm> Acesso em 24 fev. 2017.

BRITO, F. Os direitos humanos e soberania nacional. Em: AVRITZER, L. et.al. (Org.). Dimensões políticas da justiça. Rio de Janeiro: Civilização Brasileira, 2013. P. 221-229.

BROWN, W. Tolerance as a Discourse of Depoliticization. Em: BROWN, W. Regulating Aversion: Tolerance in the Age of Identity and Empire. Princeton University Press, 2008 (eBook). Disponível em: <http://press.princeton.edu/titles/8306.html> Acesso em: 10 dez. 2016.

BUSTAMANTE, T. da R. A justiça como procedimento. Em: AVRITZER, L. et.al. (Org.). Dimensões políticas da justiça. Rio de Janeiro: Civilização Brasileira, 2013. P. 105-115. 
CAMPANTE, R. G. Direitos sociais e Justiça. Em: AVRITZER, L. et.al. (Org.). Dimensões políticas da justiça. Rio de Janeiro: Civilização Brasileira, 2013. P. 369-381.

CARNEIRO, M.; VETTORAZZO, L. Desigualdade cai no Brasil com todas as classes sociais ficando mais pobres. Folha de São Paulo, 25 nov. $2016 . \quad$ Disponível em: <http://www1.folha.uol.com.br/mercado/2016/11/1835437-desigualdadecai-no-brasil-com-todas-as-classes-sociais-ficando-mais-pobres.shtml> Acesso em 20 jan. 2017.

COELHO, V. S. P. Conselhos de Saúde no Brasil: incluindo os excluídos? Em: CORNWALL, A.; COELHO, V. S. P. (Orgs.) Novos Espaços Democráticos: perspectivas internacionais. São Paulo: Singular; Esfera Pública, 2009

COSTA, F.; CUNHA, A. P. G. Sete Teses Equívocas sobre a Participação Cidadã: o dilema da democracia direta no Brasil. O\&S, v. 17, n. 54 , Salvador, p. 543-553, jul./set. 2010. Disponível em: $<$ http://www.spell.org.br/documentos/ver/489/sete-teses-equivocas-sobrea-participacao-cidada--o-dilema-da-democracia-direta-no-brasil> Acessado em: 13 out. 2016.

COSTA, S. Democracia Cosmopolita: déficits conceituais e equívocos políticos. RBCS, vol. 18, n. 53, out. 2003. Disponível em: <http://www.scielo.br/pdf/rbcsoc/v18n53/18076> Acessado em: 6 set. 2016.

Desigualdades, interdependências e afrodescendentes na América Latina. Tradução Otacílio Nunes. Tempo Social, revista de sociologia da USP, v. 24, n. 2 p. 123-145, 2012. Disponível em: <http://www.scielo.br/pdf/ts/v24n2/v24n2a07.pdf> Acesso em $20 \mathrm{dez}$. 2016.

Entangled Inequalities, State, and Social Policies in Contemporary Brazil. desigualdade.net Working Paper, n. 88, Berlin: desiguAldade.net, 2015.2 Disponível em: <http://www.desigualdades.net/Resources/Working_Paper/WP-88-CostaOnline_final.pdf> Acesso em: $13 \mathrm{dez} .2016$.

CROUCH, C.; PORTA, D. d.; STREECK, W. Democracy in neoliberalism? Antropological Theory, Vol. 16(4), p. 497-512, dez. 2016. Diponível em: <http://journals.sagepub.com/doi/abs/10.1177/1463499616677904?journal Code=anta $>$ Acesso em : 10 jan. 2017.

DAHL, R. A. A democracia e seus críticos. São Paulo: Martins Fontes, 2012.

University Press, 1971.

Polyarchy: participation and opposition. London: Yale 
DEAN, D. Law-making and Society in Late Elizabethan England: The parliament of England, 1584-1601. Cambridge: University Press, 2002.. Disponível em: <file:///C:/Users/Acer/Downloads/DeanParliamentEngland1584-1601.pdf> Acessado em 03 de jan. 2017.

DEFLEM, M. Introduction: law in Habermas's theory of communicative action. Em: DEFLEM, M. (Ed.). Habermas, Modernity, and Law. London: Sage Publications, 1996.

ENGELMANN, F. Elites Judiciárias. Em: AVRITZER, L. et.al. (Org.). Dimensões políticas da justiça. Rio de Janeiro: Civilização Brasileira, 2013. P. 479-485.

FARIA, C. F. Democracia deliberativa e Justiça. Em: AVRITZER, L. et.al. (Org.). Dimensões políticas da justiça. Rio de Janeiro: Civilização Brasileira, 2013. P. 133-139

FAORO, R. A República Inacabada. Fábio Konder Comparato (Org.). São Paulo: Globo, 2007.

Os Donos do Poder: Formação do Patronato Político Brasileiro. 5ª ed. São Paulo: Globo. 2012.

FASCIOLI, A. O Reconhecimento como Núcleo de Fundamentação da Normatividade: reflexões sobre a crítica de Honneth à ética do discurso habermasiana. Tradução Bárbara Buril. Perspectiva Filosófica, v. 43, n. 2, p. 36-63, 2016. Disponível em: $<$ http://www.revista.ufpe.br/revistaperspectivafilosofica/index.php/revistape rspectivafilosofica/article/view/139/104> Acessado em: 13 out. 2016.

FERES JR, J.; DAFLON, V. T.; CAMPOS, L. A. Ação afirmativa e Justiça. Em: AVRITZER, L. et.al. (Org.). Dimensões políticas da justiça. Rio de Janeiro: Civilização Brasileira, 2013. P. 231-241.

FILGUEIRAS, F. Accountability e Justiça. Em: AVRITZER, L. et.al. (Org.). Dimensões políticas da justiça. Rio de Janeiro: Civilização Brasileira, 2013. P. 261-269.

FONSECA, F. Democracia e participação no Brasil: descentralização e cidadania face ao capitalismo contemporâneo. Rev. Katál, Florianópolis, v. $10, \quad$ n. 2, p. 245-255, jul./dez. 2007. Disponível em: $<$ http://www.scielo.br/scielo.php?script=sci_arttext\&pid=S1414$49802007000200013>$ Acessado em: 6 jan. 2017.

FORST, R. Justification and Critique: Towards a Critical Theory of Politics. Tradução Ciaran Cronin. Cambridge: Polity Press, 2014.

. Noumenal Power. Frankfurt: Normative Order Working Paper 02/2013. Disponível em: <http://www.normativeorders.net/de/publikationen/working-paper> Acessado em: 20 abr. 2016. 
Os limites da tolerância. Tradução: Mauro de Victoria Soares. Disponível em: <http://www.scielo.br/pdf/nec/n84/n84a02.pdf> Acesso em: 9 abr. 2016.

The Right to Justification: elements of a constructivist theory of justice. Tradução: Jeffrey Flynn. New York: Columbia University Press, 2011.

FOULCAULT, M. The Subject and Power. Em: FOUCAULT, M. POWER. Tradução Robert Hurley e outros. FAUBION, J. D. (Ed.). New York: The News Press, 2000.

FRASER, N. Rethinking the Public Sphere: A Contribution to the Critique of Actually Existing Democracy. Social Text, n. 25/26, p. 56-80, 1990. Disponível em: <http://www.jstor.org/stable/466240> Acesso em $5 \mathrm{dez}$ 2016.

FRASER, N.; HONNETH, A. Redistribution or Recognition: a politicalphilosophical exchange. Tradução Joel Golb, James Ingram e Cristiane Wilke. New York: Verso, 2003.

GARCIA, G. Renan diz que 'não é bom plebiscito para consultar sobre novas eleições. Globo.com, 16 ago. 2016.

GERMANO, F. Desigualdade Social aumenta nos EUA. Exame.com, 29 dez. $2015 . \quad$ Disponível em: < http://exame.abril.com.br/economia/desigualdade-social-aumenta-noseua/> Acesso em 6 jul. 2016.

GOMES, L. Direito e questão racial. Em: AVRITZER, L. et.al. (Org.). Dimensões políticas da justiça. Rio de Janeiro: Civilização Brasileira, 2013. P. 397-409.

GUIBENTIF, P. Approaching the production of law through Habermas's concept of communicative action. Em: DEFLEM, M. (Ed.). Habermas, Modernity, and Law. London: Sage Publications, 1996.

GUIMARÃES, J. Drummond e a formação do cidadão brasileiro. Em: AVRITZER, L. et.al. (Org.). Dimensões políticas da justiça. Rio de Janeiro: Civilização Brasileira, 2013. P. 467-477.

Socialismo e Justiça. Em: AVRITZER, L. et.al. (Org.). Dimensões políticas da justiça. Rio de Janeiro: Civilização Brasileira, 2013. P. 67-75.

HABERMAS, J. Direito e Democracia: entre faticidade e validade, Vol. I. Tradução Flávio Beno Siebeneichler, Rio de Janeiro: Tempo Brasileiro, 1997. 
Paradigms of Law. Em: ARATO, A.; ROSENFELD, M. (org.). Habermas on Law and Democracy: Critical Exchanges. University of California Press, 1998.

. Pensamento Pós-Metafísico. Tradução Lumir Nahodil. Coimbra: Almedina, 2004.

Soberania Popular como Procedimento: um conceito normativo de espaço público. Tradução Márcio Suzuki. Novos Estudos, CEBRAP, n. 26, p. 100-113, mar. 1990. Disponível em: <http://novosestudos.uol.com.br/v1/files/uploads/contents/60/20080624_s oberania_popular.pdf>Acessado em: 5 dez. 2016.

The Inclusion of the Other: Studies in Political Theory. CRONIN, C.; DE GREIFF, P. (Ed.). Cambridge: Polity Press, 1999.

The Theory of Communicative Action: Reason and the rationalization of society. V. 1. Tradução Thomas McCarthy. Boston: Beacon Press, 1984.

The Theory of Communicative Action: The Critique of Functionalist Reason. V. 2. Tradução Thomas McCarthy. Cambridge: Polity Press, 1987.

HAMILTON; MADISON; JAY. O Federalista. Tradução Hiltomar Martins Oliveira. Belo Horizonte: Ed. Líder, 2003.

HOBBES, T. Do Cidadão. Tradução Renato Janine Ribeiro. $3^{\underline{a}}$ ed. São Paulo: Martins Fontes, 2002.

HOBBES, T. Leviatã ou Matéria, Forma e Poder de um Estado Eclesiástico e Civil. Tradução João Paulo Monteiro e Maria Beatriz Nizza da Silva. Em: Coleção Os Pensadores. $2^{\mathrm{a}}$ ed. São Paulo:Abril Cultura, 1979.

HOLANDA, S. B. Raízes do Brasil. Ed. Crítica. MONTEIRO, P. N.; SCHWARCZ, L. M. (Org.). São Paulo: Companhia das Letras, 2016.

HONNETH, A. The Struggle for Recognition: The Moral Grammar of Social Conflicts. Tradução Joel Anderson. Cambridge: Polity Press, 1995.

IBGE (Brasil). Censo 2010: Brasil em síntese, distribuição da população por sexo. Disponível em: $<$ http://brasilemsintese.ibge.gov.br/populacao/distribuicao-da-populacaopor-sexo.html> Acessado em: 9 jan. 2017.

PNAD 2015. Volume Brasil - 2015. Disponível em: <http://www.ibge.gov.br/home/estatistica/populacao/trabalhoerendimento/ pnad2015/brasil_defaultxls.shtm> Acesso em 20 dez. 2016.

KINGSTONE, P. R. Muddling Through Gridlock: Economic Performance, Business Responses, and Democratic Sustainability. Em: KINGSTONE, P. 
R. e POWER, T. J.. (Org.). Democratic Brazil: Actors Institutions and Processes. Pittsburgh: University of Pittsburgh Press.

LIMA, V. A. Mídia e Justiça no Brasil. Em: AVRITZER, L. et.al. (Org.). Dimensões políticas da justiça. Rio de Janeiro: Civilização Brasileira, 2013. P. 559-569.

LIMONGI, F. A Democracia no Brasil: Presidencialismo, coalizão partidária e processo decisório. Novos Estudos, n. 76, p. 17-41, 2006. Disponível em: <http://www.scielo.br/scielo.php?script=sci_arttext\&pid=S010133002006000300002> Acesso em 6 jan. 2017.

LOCATELLI, P. Brancos serão quase $80 \%$ na Câmara dos Deputados. Carta Capital, 8-12 out. 2014. Disponível em: <http://www.cartacapital.com.br/politica/brancos-serao-quase-80-dacamara-dos-deputados-3603.html> Acesso em: 10 jan. 2017.

LYRA FILHO, R. O que é direito. 18 ${ }^{\mathrm{a}}$ ed. São Paulo: Brasiliense, 2012.

MAGALHÃES, J. N. Teoria dos Sistemas. Em: AVRITZER, L. et.al. (Org.). Dimensões políticas da justiça. Rio de Janeiro: Civilização Brasileira, 2013. P. 95-103.

MAIA NETO, J. R. Capitu e sanção simbólica. Em: AVRITZER, L. et.al. (Org.). Dimensões políticas da justiça. Rio de Janeiro: Civilização Brasileira, 2013. P. 289-295.

MANSBRIDGE, J. et al. A systemic approach to deliberative democracy. Em: PARKINSON, J.; MANSBRIDGE, J. (Ed.) Deliberative Systems. Cambridge: University Press, 2012.

MARTINS, P. G.; GONTIJO, L. A. Teoria do Reconhecimento e Economia Solidária: uma proposta de recomposição entre igualdade e solidariedade. Revista Duc In Altum Cadernos de Direito, v. 8, n. 16, p. 197-219, set./dez. 2016. Disponível em: $<$ http://www.faculdadedamas.edu.br/revistafd/index.php/cihjur/article/view/ 401/390> Acessado em: 5 jan. 2017.

MATOS, A. R. "Eu participo, tu participas...nós protestamos": ações de protesto, democracia e participação em processos de decisão. $\mathbf{O}$ público e o privado, n. 27, p. 119-136, jan./jun. 2016. Disponível em: <http://www.seer.uece.br/?journal=opublicoeoprivado\&page=article\&op=vi ew\&path\%5B\%5D=2156> Acessado em: 6 jan. 2017.

MATOS, M. Feminismo. Em: AVRITZER, L. et.al. (Org.). Dimensões políticas da justiça. Rio de Janeiro: Civilização Brasileira, 2013. P. 141 157.

MEDEIROS, M.; SOUZA, P. H. G. F.; CASTRO, F. A. O Topo da Distribuição de Renda no Brasil: Primeiras Estimativas com Dados Tributários e Comparação com Pesquisas Domiciliares (2006-2012). 
DADOS, Revista de Ciências Sociais, Rio de Janeiro, v. 58, n. 1, p. 7-36, 2015. Disponível em: <http://dx.doi.org/10.1590/00115258201537> Acessado em: 6 jan. 2017.

MEDONÇA, R. F. Reconhecimento. Em: AVRITZER, L. et.al. (Org.). Dimensões políticas da justiça. Rio de Janeiro: Civilização Brasileira, 2013. P. 117-131.

MELO, A. C. Saudosismo e crítica social em Casa grande \& senzala: a articulação de uma política de memória e de uma utopia. Estudos Avançados, v. 23, n. 67, p. 279-296, dez. 2010. Disponível em: $<$ http://www.scielo.br/scielo.php?script=sci_arttext\&pid=S0103$40142009000300031>$ Acesso em: 14 dez. 2016.

MELLO, C. A. B. de. A democracia e suas dificuldades contemporâneas. Em: Revista Eletrônica sobre a Reforma do Estado, Bahia, $\mathrm{n}^{\circ}$ 9, março/abril/maio, 2007. Disponível em: <http://www.direitodoestado.com/revista/RERE-9-MAR\%C7O-2007CELSO\%20ANTONIO.pdf> Acessado em: 30 ago. 2015.

MOUFFE, C. Deliberative Democracy or Agonistic Pluralism. Reihe Politikwissenschaft - Political Science Series, n. 72, Vienna, IHS, p. 2000. Disponível em: <https://www.ihs.ac.at/publications/pol/pw_72.pdf> Acessado em: 5 jun. 2016.

NICOLAU, J. Eleições no Brasil: Do Império aos dias atuais. Rio de Janeiro: Zahar, 2012.

OLIVEIRA, Gustavo Justino. A Administração Consensual como a Nova Face de Administração Pública no Século XXI: Fundamentos Dogmáticos, Formas de Expressão e Instrumentos de Ação. Em: BDA - Boletim de Direito Administrativo - abr. 2009.

ONUBR. Brasil: teto de $\mathbf{2 0}$ anos para o gasto público violará direitos humanos, alerta relator da ONU. 9 dez. 2016. Disponível em: $<$ https://nacoesunidas.org/brasil-teto-de-20-anos-para-o-gasto-publicoviolara-direitos-humanos-alerta-relator-da-onu/> Acesso em: 3 jan. 2016

PEREIRA, H. D. Conflitos urbanos e Direito no Brasil. Em: AVRITZER, L. et.al. (Org.). Dimensões políticas da justiça. Rio de Janeiro: Civilização Brasileira, 2013. P. 445-453.

PILATTI, A. A Constituinte de 1987-1988: Progressistas, Conservadores, Ordem Econômica e Regras do Jogo. Rio de Janeiro: Lumen Juris, 2008.

Disponível em: <http://www.ihu.unisinos.br/entrevistas/526897-essesjovens-guerreiros-lutam-pela-realizacao-dos-objetivos-fundamentais-darepublica-entrevista-especial-com-adriano-pilatti> Acesso em $10 \mathrm{dez}$. 2016. 
PILATTI, A.; COCCO, G. Quem tem medo do poder constituinte? IHU On-line, 15 jul. 2013. Disponível em: <http://www.ihu.unisinos.br/521906quem-tem-medo-do-poder-constituinte-> Acesso em: 6 nov. 2016.

PILATTI, A; NEGRI, A; COCCO, G. Levante da Multidão. Disponível em: $<$ http://uninomade.net/tenda/levante-da-multidao/>. Acesso em: 13 jan. de 2016.

PERES, P. S. A barganha nas vísceras do modo brasileiro de governar. IHU On-Line. Porto Alegre, 8 ago. 2016. Disponível em: $<$ http://www.ihuonline.unisinos.br/index.php?option=com_content\&view=ar ticle\&id $=6562 \&$ secao $=490>$ Acessado em: 3 jan. 2017.

POGREBISCHI, T. Democracia Pragmática: Pressupostos de uma Teoria Normativa Empiricamente Orientada. DADOS, Revista de Ciências Sociais, Rio de Janeiro, v. 53, n. 3, p. 657-693, 2010. Disponível em: $<$ http://www.scielo.br/scielo.php?script=sci_arttext\&pid=S0011-

52582010000300005> Acessado em: 6 abr. 2016.

The Pragmatic Turn of Democracy in Latin

America. Berlin: Friedrich Ebert Stiftung, ago. 2013. Disponível em: <http://library.fes.de/pdf-files/iez/10209.pdf> Acessado em: 15 abr. 2016.

RANCIÈRE, J. $O$ ódio à democracia. Tradução Mariana Echalar. $1^{\text {a }}$ ed. São Paulo: Boitempo, 2014.

ROCHA, L. M. L. N. Feminismo, Gênero e Políticas Públicas: desafios para fortalecer a luta pela emancipação. R. Pol. Públ. Número Especial, São Luís, p. 313-322, nov. 2016. Disponível em: <http://www.periodicoseletronicos.ufma.br/index.php/rppublica/article/view File/5982/3617> Acessado em: 6 jan. 2017.

SALM, R. Belo Monte: a farsa das audiências públicas. Correio da Cidadania, 5 out. 2009. Disponível em: <http://www.correiocidadania.com.br/index2.php?option=com_content\&do _pdf=1\&id=3827> Acesso em: 10 jan. 2017.

SANTOS, B. de S.; ARVRITZER, L. Introdução: para ampliar o cânone democrático. Em: SANTOS, B. de S. (Org.). Democratizar a democracia: os caminhos da democracia participativa. Rio de Janeiro: Civilização Brasileira, 2002.

SANTOS, F. F. F. A Teoria Discursiva Habermasiana e o Exercício da Cidadania Fiscal. Em: BUSTAMANTE, T.; SAMPAIO, J. A. L.; COSTA, B. S. (Org.). Perspectivas Históricas e Jurídico-Filosóficas sobre Constitucioanlismo. Anais II Congresso Internacional de Direito Constitucional e Filosofia Política, v. 5, Belo Horiznte: Initia Via, 2016. Disponível em: <https://dx.doi.org/10.17931/DCFP2015_V05_A69> Acessado em: 9 out. 2016. 
SCHARCZ, L. Tenda dos milagres. Em: AVRITZER, L. et.al. (Org.). Dimensões políticas da justiça. Rio de Janeiro: Civilização Brasileira, 2013. P. 281-287.

SIMTH, Sir T.. De Republica Anglorum: A discourse on the Commonwealth of England. ALSTON, L. (Ed.). Cambridge: University Press, $1906 . \quad$ Disponível em: <http://www.mindserpent.com/American_History/books/Smith_Thomas/15 83_smith_commonwealth_of_england.pdf > Acessado em 03 jan. 2017.

SOUZA, P. H G. F.; MEDEIROS, M. Top Income Shares and Inequality in Brazil, 1928-2012. SID, Porto Alegre, v. 1, n. 1, p. 119-132, jul./dez. 2015. Disponível em: <http://diagramaeditorial.com.br/sid/index.php/sid/article/view/2/23> Acessado em: 6 jan. 2017.

TERENZI, G.; AZEVEDO, R. Alvos da Lava Jato doaram R $\$ 73$ mi para Dilma e Aécio. Folha de São Paulo, 27 nov. 2014. Disponível em: $<$ http://www1.folha.uol.com.br/poder/2014/11/1553906-alvos-da-lava-jatodoaram-r-77-mi-para-dilma-e-aecio.shtml> Acesso em 8 jan. 2017.

TSE (Brasil). Divulgação da prestação de contas - Eleições 2014. Disponível em: <http://www.tse.jus.br/eleicoes/eleicoesanteriores/eleicoes-2014/prestacao-de-contas-eleicoes-2014/divulgacaoda-prestacao-de-contas-eleicoes-2014> Acesso em 8 jan. 2017.

Estatísticas eleitorais 2014. Disponível em: <http://www.tse.jus.br/eleicoes/estatisticas/estatisticas-candidaturas2014/estatisticas-eleitorais-2014-resultados> Acessado em 8 jan. 2017.

VILLAS-BÔAS, M. A. A concentração de renda é maior do que se imaginava. Carta Capital, 26 jan. 2016. Disponível em: $<$ http://www.cartacapital.com.br/economia/brasil-um-dos-paises-maisdesiguais-do-mundo> Acesso em: 5 jan. 2017.

WARREN, M. E. Deliberative Democracy and the Corruption of Speech. Em: APSA 2012 Annual Meeting, 30 ago./2 set. 2012. Disponível em: $<$ https://ssrn.com/abstract=2104776> Acessado em: 3 fev. 2016

YOUNG, I. O ideal da Imparcialidade e o público cívico. Em: MIGUEL, L. F.; BIROLI, F. (orgs). Teoria Política Feminista. Belo Horizonte: UFMG, 2013. 